\author{
UNIVERSIDADE DE SÃO PAULO \\ FACULDADE DE FILOSOFIA, LETRAS E CIÊNCIAS HUMANAS \\ DEPARTAMENTO DE ANTROPOLOGIA \\ PROGRAMA DE PÓS-GRADUAÇÃO EM ANTROPOLOGIA SOCIAL \\ VINÍCIUS AUGUSTO GUERRA SPIRA
}

Desafios do acolhimento e práticas espaciais:

os Centros Educacionais Unificados (CEUs) de São Paulo

versão corrigida

São Paulo

2015 
UNIVERSIDADE DE SÃO PAULO

FACULDADE DE FILOSOFIA, LETRAS E CIÊNCIAS HUMANAS

DEPARTAMENTO DE ANTROPOLOGIA

PROGRAMA DE PÓS-GRADUAÇÃO EM ANTROPOLOGIA SOCIAL

\section{Desafios do acolhimento e práticas espaciais: os Centros Educacionais Unificados (CEUs) de São Paulo}

Vinícius Augusto Guerra Spira

Dissertação apresentada à Faculdade de Filosofia, Letras e Ciências Humanas da Universidade de São Paulo para obtenção do título de Mestre em Antropologia Social. Área de Concentração: Antropologia Social.

Orientadora: Profa. Dra. Fernanda Arêas Peixoto



versão corrigida

São Paulo

2015 
Autorizo a reprodução e divulgação total ou parcial deste trabalho, por qualquer meio convencional ou eletrônico, para fins de estudo e pesquisa, desde que citada a fonte. 
SPIRA, Vinícius Augusto Guerra

Desafios do acolhimento e práticas espaciais: os Centros Educacionais Unificados (CEUs) de São Paulo. Dissertação apresentada à Faculdade de Filosofia, Letras e Ciências Humanas da Universidade de São Paulo para obtenção do título de Mestre em Antropologia Social.

Aprovado em: 1

Banca Examinadora

Profa. Dra. Fernanda Arêas Peixoto Instituição: Depto. Antropologia Social Faculdade de Filosofia, Letras e Ciências Humanas - Universidade de São Paulo Assinatura:

Prof. Dr. Adrian Gurza Lavalle Instituição: Depto. Ciência Política - Faculdade de Filosofia, Letras e Ciências Humanas Universidade de São Paulo

Assinatura:

Prof. Dr. Eduardo Álvarez Pedrosian Instituição: Depto. de Ciencias Humanas y Sociales, Instituto de Comunicación de la Facultad de Información y Comunicación de la Universidad de la República.

Assinatura: 


\section{AGRADECIMENTOS}

Gostaria de agradecer a todos os usuários e funcionários dos CEUs que colaboraram para a realização desta pesquisa, dentre eles: Ademir Takara, Aira Bonfim, Aline Tavella, Ana Carolina Barbosa Pereira, Ana Lígia Contell, Anísio Jorge Neto, Anselina Soares, Arlete de Oliveira, Caio Nascimento Uehbe, Carlos Pinheiro, Cláudio Ferreira, Cristina Jorge, Daniela Oliveira, Daniela Sano, Diego Machado, Diná Ramos, Durval Reis, Éder Magalhães, Elaine Silva, Eliana Scaravelli Arnold, Eliane Aparecida dos Santos Luscri, Fábia Roberta da Silva Santos, Fernanda Alvez, Fernando Molnar, Francisco Bernardino Leite, Gilmara Santos, João Eduardo Cruz da Silva, João Luís Carvalho, Julia Ferreira, Julio César Ladeia, Kleber Henriques Massi, Lenita Garcia, Lis Paglioni Bonadio, Luanna Caetano Maciel da Silva, Marcelo Páscoli, Luís Prates, Marcos Rodrigues Coutinho, Maria de Lourdes Toffoletto, Maria Francisca Pereira dos Santos, Maria Sônia Henrique, Patrícia Maria Takada, Reinaldo Vieira de Carvalho, Richard Rinaldi, Róberson Cristiano de Souza, Sabrina Copi Boghazdelikian, Sabrina Teixeira, Sandra Moreira, Tânia Sampaio, Valdirene Floriano e Viviane Ramos. Agradeço especialmente à coordenadora da biblioteca do CEU Butantã, Regina Alzira Ferreira, por suas agudas reflexões ao longo de inúmeras conversas, e pelo convite para participar da reforma da biblioteca do CEU Butantã. Também dedico um agradecimento especial aos arquitetos Alexandre Delijaicov e André Takyia, pelos depoimentos sempre muito comprometidos com as primeiras ideias que conceberam para os CEUs. Agradeço também à educadora Anna Cecília Koebcke de Magalhães Couto Simões, ex-gestora do CEU Butantã, com quem realizei algumas entrevistas e visitas emocionantes aos CEUs. No âmbito acadêmico, agradeço à Fundação de Amparo à Pesquisa do Estado de São Paulo (Fapesp) pelo apoio à pesquisa - por meio de uma bolsa de mestrado -, à Coordenação de Aperfeiçoamento de Pessoal de Nível Superior (Capes), a todos os amigos do Coletivo ASA e do NAU Cidades. Vale ressaltar as inestimáveis contribuições de minha orientadora, Fernanda Arêas Peixoto, e das leituras e comentários dos professores José Guilherme Cantor Magnani e Eduardo Marques (por ocasião da qualificação). Agradeço também aos professores Adrian Gurza Lavalle e Eduardo Álvarez Pedrosian por suas indicações de leitura e inspirações teóricas. Na revisão do texto, foi fundamental a contribuição de André Albert. Finalmente, agradeço pelo apoio de pessoas sem as quais esta pesquisa não teria sido possível: a todos os meus familiares, à minha amiga Cristiane dos Santos Mendes Alves, à minha mestra Monja Coen Roshi e à minha querida companheira Taís Jamra Tsukumo. 
"Quando os CEUs começaram a ser inaugurados, a distância aparentemente invencível entre aquelas pessoas e a possibilidade de uma vida melhor tinha subitamente desaparecido." Marta Suplicy, Minha vida de prefeita. p. 50.

"A maior dificuldade não foi construir o prédio, foi construir as relações entre as pessoas. Ninguém estava acostumado àquela realidade, era como se fosse um grupo de estrangeiros chegando juntos numa terra desabitada e estranha. Apesar de bonita, estranha." Ricardo de Souza, A educação social em espaços de experimentação pedagógica: as potencialidades dos CEUs. p. 214. 


\section{RESUMO}

SPIRA, Vinícius Augusto Guerra. Desafios do acolhimento e práticas espaciais: os Centros Educacionais Unificados (CEUs) de São Paulo. 2015. 207 f. Dissertação (Mestrado em Antropologia Social). Faculdade de Filosofia, Letras e Ciências Humanas, Universidade de São Paulo, São Paulo, 2015.

Os Centros Educacionais Unificados (CEUs) reúnem um conjunto de equipamentos de educação, cultura, esporte e lazer, e configuram centralidades urbanas em muitas das áreas mais periféricas de São Paulo. A pesquisa utiliza o termo acolhimento para referir-se à intenção de muitos servidores públicos dos CEUs de entregar benefícios aos moradores dessas áreas e de estabelecer relações de diálogo e reciprocidade com eles. O acolhimento depende do modo como se dão as interações cotidianas entre usuários e funcionários, e de como estas interações são influenciadas por espaços, normas, leis e diretrizes de um modo geral. A influência de aspectos como esses sobre as interações é objeto de uma investigação etnográfica realizada entre 2010 e 2014 entre gestores, bibliotecários e usuários dos CEUs Butantã e Vila Rubi. Destaca-se a proposição de uma tipologia de influências - designadas contextos extensivos, intensivos e separadores - que vai além do pressuposto de que o acolhimento se efetiva exclusivamente por meio de espaços abertos e de outras formas de garantia de liberdades de ação e interação. Vale mencionar também que a pesquisa associa investigação e intervenção, pela sugestão de linhas de ação aos servidores dos CEUs e pela implementação e análise de uma reforma dos espaços da biblioteca do CEU Butantã - realizada com base em minha dupla formação em antropologia e arquitetura.

Palavras-chave: acolhimento, interações, cotidiano, periferia, espaço, arquitetura, equipamentos públicos, escolas, bibliotecas. 


\begin{abstract}
SPIRA, Vinícius Augusto Guerra. Chalenges of embracing and spatial practices: the Unified Educational Centers (CEUs) of São Paulo. 2015. 207 f. Dissertation (Master in Social Anthropology). Faculdade de Filosofia, Letras e Ciências Humanas, Universidade de São Paulo, São Paulo, 2015.

The Unified Educational Centers (Centros Educacionais Unificados, or CEUs) bring together a set of educational, cultural, sports and leisure facilities in one space, and therefore, constitute urban centralities in many of the most peripheral areas of São Paulo. In this study, the term "embracing" is used to refer to the intention of many public servants at the CEUs to provide benefits to the inhabitants of these areas, and to establish relationships based on dialogue and reciprocity with them. Embracing depends on the way daily interactions between users and employees take place, and how spaces, norms, laws and guidelines influence these interactions in general. The influence of these aspects on interactions was the object of an ethnographic study conducted between 2010 and 2014 among managers, librarians and users of the Butantã and Vila Rubi CEUs. We highlight here the proposal of a typology of influences, designated as extensive, intensive and separating contexts. The typology proposed goes beyond the assumption that embracing occurs exclusively in open spaces and via other ways to guarantee freedom of action and interaction. It is also worth mentioning that the study associates investigation with intervention, by including suggestions on courses of action for the public servants at the CEUs, and on the implementation and analysis of a reform of the Butantã CEU's library spaces. These recommendations are based on my training in both anthropology and architecture.
\end{abstract}

Keywords: embracing, interactions, periphery, space, architecture, public equipments, schools, libraries. 


\section{LISTA DE FIGURAS}

Figura 1 - Conjunto da Liberdade: Esquema da implantação do conjunto escolasclasse/escola-parque na configuração topográfica local. Distância entre as escolas-classe e a escola-parque varia de 1 a $2 \mathrm{~km}$. Crédito: Adaptado pela equipe Livi do original de Alice Seiko Matsumoto. Extraído de Duarte (2009, p. 111)......................................................................26

Figura 2 - Mapa de localização dos CEUs no município de São Paulo.............................................. 34

Figura 3 - Esboço do primeiro projeto dos CEUs. Arquivo Edif/SME. Extraído de Doria

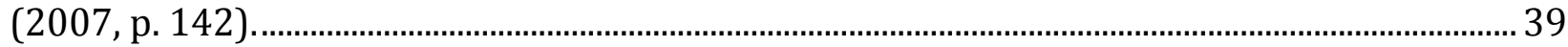

Figura 4 - Perspectiva do bloco do CEI, conforme primeiro projeto arquitetônico dos CEUs.

Figura 5 - Vista do bloco circular do CEI, no CEU Butantã........................................................... 41

Figura 6 - Perspectiva do bloco cultural - conforme primeiro projeto arquitetônico dos

CEUs.

Figura 7 - Teatro Oficina, com palco em forma de uma rua e arquibancadas suspensas.

Extraído de Bardi e Elito (1999).........................................................................................................4 43

Figura 8 - Vista do bloco cultural do CEU Butantã. ....................................................................... 44

Figura 9 - Perspectiva do bloco educacional - conforme primeiro projeto arquitetônico dos

CEUs.

Figura 10 - Corredor de circulação da EMEF, com vista para o interior das salas de aula e para a paisagem urbana circundante. 46

Figura 11 - Centro Cultural São Paulo, com caminhos diversos e ausência de portas de entrada. Crédito: Cristiano Mascaro. Extraído de Serapião (2012, p. 135)...

Figura 12 - Organograma dos CEUs na gestão Marta Suplicy (2001-2004). ............................. 52

Figura 13 - Perspectiva das escolas - conforme o segundo projeto arquitetônico dos CEUs.

Figura 14 - Vista exterior do CEU Vila Rubi, com fechamentos laterais em lajes pré-

fabricadas. .58

Figura 15 - Vista exterior do CEU Paraisópolis, com grades e espaços intersticiais................59

Figura 16 - Perspectiva da gestão - conforme o segundo projeto arquitetônico dos CEUs.. 60 Figura 17 - Perspectiva da biblioteca, do telecentro e do refeitório - conforme o segundo projeto arquitetônico dos CEUs.

Figura 18 - Perspectiva do bloco esportivo e cultural - conforme o segundo projeto arquitetônico dos CEUs.

Figura 19 - Estúdios da FAU-USP, com rampa de circulação em primeiro plano. Fotografia

de autoria desconhecida. Extraído de Ferraz (1997, p. 111).

Figura 20 - Salas de aula com meia parede, dos CIEPs. Autoria desconhecida. Extraída de

Ribeiro, 1986.

Figura 21 - Diagrama de contextos.

Figura 22 - Tipos de contexto em função de distâncias.

Figura 23 - Tipos de contexto em função de configurações de abertura e fechamento espacial...

Figura 24 - Foto aérea do CEU Butantã e entorno. Aglomerados "subnormais": 1-Favela do Sapê; 2-Castelinho; 3-Favela da Água Podre; 4-Favela São Domingos ("Rua Oito"); 5-Rio Pequeno; 6-Jardim das Vertentes; 7-Jardim Jaqueline; 8-Mandioquinha.. 
Figura 26 - Portão de acesso secundário ao CEU, conhecido como "P6". Ao fundo podemos ver a encosta encimada pela pista de skate. 93

Figura 27 - Vista da encosta na porção norte do CEU Butantã, com pista de skate em primeiro plano, e edifícios do CEU ao fundo. 94

Figura 28 - Lago e caminho principal da porção norte do CEU Butantã.................................... 94 Figura 29 - Rampa de interligação das porções norte e sul do CEU Butantã, com parquinho à esquerda, grades à direita e bloco cultural ao fundo. 95 Figura 30 - Vista do CEI em direção às praças de circulação (depois da área das piscinas) e aos outros edifícios do patamar sul do CEU Butantã: à direita da imagem, o bloco pedagógico; ao fundo, o bloco cultural. 96

Figura 31 - Vista dos fundos do bloco educacional do CEU Butantã 98 Figura 32 - Foto aérea do CEU Vila Rubi e entorno. Aglomerados "subnormais": 1-Jardim das Imbuias; 2-Iporanga/Jardim Bonito; 3-Jardim Presidente; 4-Parque Alto; 5-Vila Rubi.

Figura 33 - Perspectivas do CEU Vila Rubi.

Figura 34 - Rua principal de circulação do CEU Vila Rubi, com edifício da gestão em primeiro plano e edifício circular do refeitório, biblioteca e telecentro ao fundo. Figura 35 - Esquina e eixo secundário de circulação do CEU Vila Rubi, com edifício do CEI e da EMEI à esquerda e bloco esportivo cultural à direita. 120

Figura 36 - Banco de concreto com meninos sentados, CEU Vila Rubi.

Figura 37 - Fila para entrada no refeitório do CEU Vila Rubi. 131 Figura 38 - Guichê de atendimento no térreo do edifício da gestão do CEU Vila Rubi, com Luís Prates realizando o atendimento. À direita da imagem, o gestor Cláudio Ferreira...... 132 Figura 39 - Canteiro cultivado pelos alunos do CEU Vila Rubi, em cursos de jardinagem. 136 Figura 40 - Festa junina realizada no CEU Vila Rubi em 15/06/2013. 138 Figura 41 - Sorteio de rifas na festa junina do CEU Vila Rubi, em 15/06/2013..................... 139 Figura 42 - Barracas de artesanato na festa junina do CEU Vila Rubi, em 15/06/2013 .... 140 Figura 43 - Perspectiva ilustrativa da biblioteca do CEU Butantã (2013)............................. 153 Figura 44 - Perspectiva ilustrativa do projeto original da biblioteca do CEU Butantã......... 154 Figura 45 - Perspectiva da biblioteca do CEU Vila Rubi (2013).............................................. 157 Figuras 46 e 47 - Espaços de recepção dos CEUs Vila Rubi (à esquerda) e Butantã (à direita) 161

Figuras 48 e 49 - Controles de acesso às bibliotecas dos CEUs Vila Rubi (à esquerda) e Butantã (à direita).

Figuras 50 e 51 - Espaços dos computadores. No CEU Vila Rubi (à esquerda) as estantes infantojuvenis separam usuários de computadores do ambiente de leitura. A imagem da direita retrata o espaço dos computadores na biblioteca do CEU Butantã. Figuras 52 e 53 - Estantes. Na imagem do CEU Vila Rubi (à esquerda), vê-se a entrada e a recepção ao fundo. No CEU Butantã (à direita), as estantes formam diversos corredores e caminhos. 169

Figuras 54 e 55 - Catalogação. Na imagem do CEU Butantã (à esquerda), diversos armários formam um espaço separado, tendo as mesas de leitura à esquerda e as estantes ao fundo. Na imagem do CEU Vila Rubi (à direita), a mesa de catalogação avizinha-se do corredor de computadores e das estantes infantojuvenis. 171 Figura 56 - Perspectiva da reforma da biblioteca do CEU Butantã. 
Figura 57 - Foyer da biblioteca do CEU Butantã, com picadeiros, após a reforma. Atrás dos picadeiros encontra-se o corredor de acesso ao banheiro e à copa dos funcionários. Figura 58 - Vista da ilha de recepção e porta de entrada da biblioteca do CEU Butantã, após a reforma.

Figura 59 - Campo de visão dos bibliotecários situados na mesa da recepção da biblioteca do CEU Butantã, após a reforma.

Figura 60 - Novo corredor de circulação central da biblioteca do CEU Butantã, após a reforma.

Figura 61 - Ambiente para leitura informal do CEU Butantã após a reforma, em primeiro plano. Logo após podem ser avistadas as mesas redondas, os revisteiros (à esquerda da imagem) e o corredor de acesso ao ambiente de catalogação e coordenação (na extrema esquerda).

Figura 62 - Vista do corredor central da biblioteca do CEU Butantã, com nova disposição dos computadores e televisores. 188

Figura 63 - Conversa através dos armários baixos que separam o novo ambiente de coordenaç̧ão e catalogação do resto da biblioteca do CEU Butantã. Ao fundo podem ser vistos os revisteiros. 


\section{SUMÁRIO}

INTRODUÇÃO - UNIVERSO, PERCURSO E PROBLEMA DA PESQUISA............................................14

CAPÍTULO 1 - PROJETOS, INTENÇÕES E CONTEXTOS: ENSAIANDO UM MODELO DE ANÁLISE 24

1.1. Caracterização dos CEUs.....................................................................................................24

1.2. Acolhimento e contexto: definições preliminares ................................................................. 35

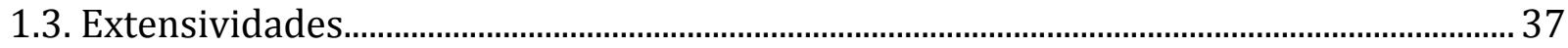

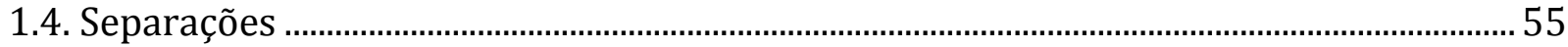

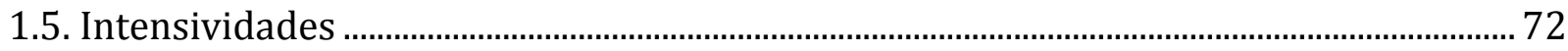

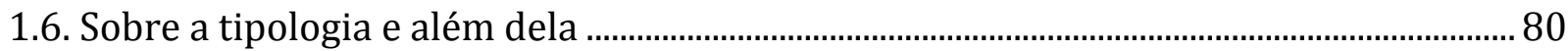

CAPÍTULO 2 - ACOLHIMENTO, ORGANIZAÇÃO E SEGURANÇA: DESAFIOS DA GESTÃO DOS

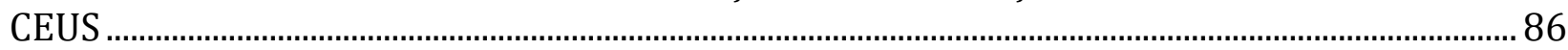

2.1. CEU Butantã: extensividades versus separações .............................................................. 88

2.1.1 Extensividades espaciais............................................................................................ 89

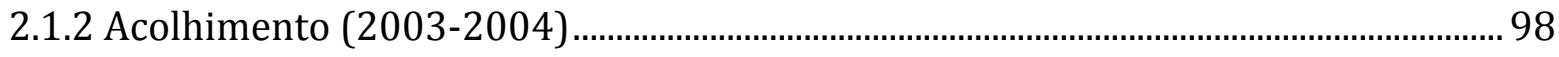

2.1.3 Organização e segurança (2005-2012) ........................................................................ 101

2.1.4 Afastamentos, acomodações e intensividades........................................................... 108

2.1.5 "Retomada" do acolhimento (2013-2014) ................................................................ 111

2.2. CEU Vila Rubi: combinações de âmbitos e contextos .......................................................... 116

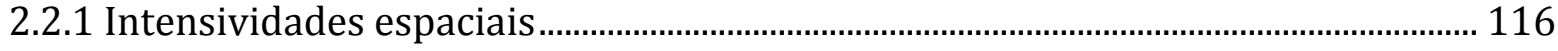

2.2.2 Separações como articuladoras da intensividade ..................................................... 126

2.2.3 Predomínio de extensividades........................................................................................... 134

2.3. CEUs e escolas...................................................................................................................... 141

CAPÍTULO 3 - ENTRE "USUÁRIOS" E "LIVROS": INVESTIGAÇÃO E INTERVENÇÃO NAS

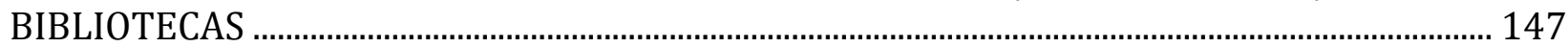

3.1. Bibliotecas de CEU ………….............................................................................................. 148

3.2. Biblioteca do CEU Butantã: "usuários" ou "livros" ............................................................. 152

3.3. Biblioteca do CEU Vila Rubi: "foco no social" .................................................................. 156

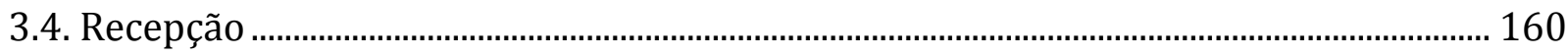

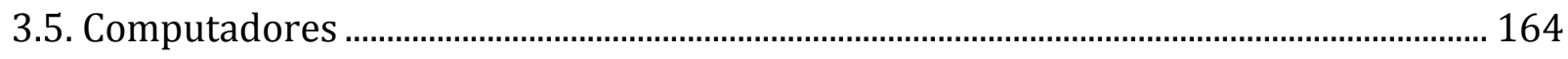

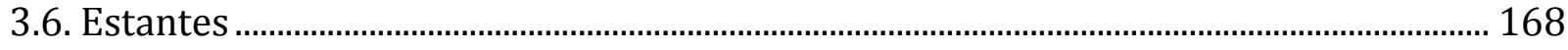



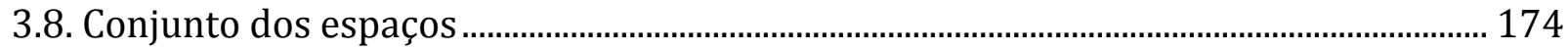

3.9. Reforma da biblioteca do CEU Butantã............................................................................... 177 


\section{INTRODUÇÃO - UNIVERSO, PERCURSO E PROBLEMA DA PESQUISA}

Os Centros Educacionais Unificados (CEUs) são uma das políticas públicas mais relevantes de combate à desigualdade já implementadas em São Paulo. Atualmente, eles formam uma rede de 45 unidades, implantadas nos lugares mais pobres e desfavorecidos da metrópole paulistana, oferecendo um conjunto de equipamentos e atividades de educação, cultura, esporte e lazer. ${ }^{1} \mathrm{O}$ dia a dia de um CEU é composto por inúmeras interações entre pessoas que não costumam conviver em outros lugares da cidade: educadores e alunos de diferentes escolas; artistas de passagem e skatistas do bairro; moradores de comunidades locais e visitantes de áreas distantes; funcionários públicos e usuários de diversas idades, proveniências, filiações políticas e visões de mundo.

Como se dão e como podem se dar as interações entre os frequentadores dos CEUs? De que modo elas são condicionadas por características espaciais, por normas de funcionamento, canais de participação política, hierarquias de poder entre funcionários? Esta pesquisa pretende mostrar como esses aspectos afetam a política das interações cotidianas nos CEUs. Projetos, espaços, normas e diretrizes vigentes nos centros educacionais são fatores que devem ser levados em conta na análise das dinâmicas interacionais que aí têm lugar: eles servem como uma espécie de palco para as interações, podendo ser designados como os seus contextos. As influências que esses fatores produzem nas interações cotidianas não é novidade nem para aqueles que concebem e constroem os CEUs, nem para os que, posteriormente, precisam lidar com o que foi implementado - e, eventualmente, modificá-lo. Todos têm seus próprios pressupostos e intenções ao defender espaços mais abertos ou mais fechados, normas de funcionamento mais rigorosas ou mais flexíveis, hierarquias ou simetrias de poder, diretrizes pedagógicas etc.

Uma das principais intenções que motivam a implementação ou a alteração desses contextos das interações nos CEUs é a promoção do que optei por designar como acolhimento. Nos termos deste trabalho, acolhimento refere-se a uma preocupação geral em beneficiar os moradores das áreas periféricas em que os CEUs se encontram. Como garantir que as atividades e recursos sejam

\footnotetext{
${ }^{1}$ Os CEUs abrigam os seguintes equipamentos: CEI (Centro de Educação Infantil), EMEI e EMEF (Escolas Municipais de Educação Infantil e de Ensino Fundamental), telecentro (sala de informática), teatro, ginásio de esportes, biblioteca, piscinas e salas para cursos diversos. Certos espaços e atividades não estão presentes em todos eles: salas de dança, padaria-escola, pista de skate e espaços maiores ou menores de lazer externo que variam em função das condições de cada terreno (PADILHA; SILVA, 2004). Muitos CEUs também oferecem EJA (Educação de Jovens e Adultos) e abrigam ETECs (Escola Técnica Estadual).
} 
oferecidos e procurados pelas pessoas? Muitos dos servidores dos CEUs - e também alguns de seus frequentadores - buscam continuamente incentivar o interesse e o envolvimento das pessoas em cursos, festas, atividades pedagógicas, eventos esportivos, artísticos e culturais. Esta preocupação costuma associar-se ao estabelecimento de relações de diálogo e mútuo entendimento, em que o público-alvo é tratado com base na ideia de igualdade, mesmo quando existem assimetrias de poder entre uns e outros.

Ao falar da promoção de atividades e reciprocidades entre as pessoas, temos uma definição de acolhimento que é suficientemente genérica para fazer referência a um conjunto muito amplo de ideias e práticas afins - por isso mesmo ela foi escolhida. Com uma só palavra, podemos nos endereçar às intenções de diversos profissionais: educadores, políticos, arquitetos, bibliotecários, produtores culturais, entre outros. Cada um deles carrega seu próprio arsenal de valores, visões de mundo, materiais e técnicas de promoção do acolhimento. Essas intenções não necessariamente possuem uma origem comum, mas encontram modos diversos de se associar e proliferar. Elas são difíceis de serem acompanhadas, mas podem ser flagradas, aqui e ali, na forma de discursos específicos ou gerais, novos ou consagrados. ${ }^{2}$

Uma inspiração central para educadores e servidores relacionados aos CEUs é a pedagogia da libertação de Paulo Freire (1968). Ela pode ser aproximada da noção de acolhimento aqui empregada por defender uma educação baseada em um espírito de cooperação, convívio e solidariedade entre professores e alunos, e por se preocupar ainda em produzir uma consciência crítica em relação aos processos de exploração e dominação presentes nas sociedades. Para alcançar esses objetivos, o ideário freiriano critica as práticas "tradicionais" e "autoritárias" de ensino, e estabelece diretrizes pedagógicas que funcionam como contextos das interações entre educandos e educadores. Dentre essas diretrizes, está a que determina que os conteúdos letivos sejam definidos a partir da visão de mundo e dos interesses imediatos dos alunos, para que eles aprendam de forma livre e voluntária. Além disso, a pedagogia da libertação determina relações de simetria de poder entre educandos e educadores, seguindo a ideia de que ninguém ensina ninguém, mas todos aprendem e constroem conhecimento em conjunto (FREIRE, 1968). Vale notar que essas diretrizes não chegaram a ser implementadas nos CEUs ou em suas escolas, mas são

\footnotetext{
${ }^{2}$ A nossa definição de acolhimento não coincide e não precisa coincidir inteiramente com os modos como o termo é utilizado no cotidiano dos CEUs. Ela é uma interpretação, nem muito próxima nem muito distante das intenções de nossos sujeitos de pesquisa. Nos termos de Geertz (1983), trata-se de uma construção téorica situada entre os níveis êmico e ético. O mesmo vale para o modo como definimos contexto, mais acima. Isto ficará mais claro posteriormente.
} 
referências importantes no seu dia a dia.

No âmbito político-administrativo, o acolhimento leva a uma descentralização da gestão municipal que pode ser entendida como contexto favorecedor de interações semelhantes às propostas por Paulo Freire. No governo Marta Suplicy (2001-2004) - quando os primeiros 21 CEUs foram criados - descentralizar a gestão significava incentivar a autonomia e a participação popular nos processos decisórios de governo, com a entrega de recursos e poderes às pontas da máquina estatal, onde as políticas são efetivamente implementadas. A cidade assistiu à criação das Subprefeituras. Os CEUs foram concebidos com conselhos gestores - e outros canais de gestão participativa - de frequência voluntária, e visavam estabelecer relações horizontais entre funcionários e usuários. Boa parte da força e da importância desses contextos administrativos se enfraquece do governo José Serra (2005-2006) em diante, mas eles continuam sendo relevantes para a constituição das dinâmicas interacionais no cotidiano da gestão dos CEUs em geral. Para promover o acolhimento, os CEUs dependem até hoje de uma boa dose de interações livres e voluntárias entre as pessoas.

O espaço é um terceiro âmbito importante para a promoção do acolhimento. Neste caso, os primeiros 21 CEUs contaram com uma concepção arquitetônica e urbanística preocupada em oferecer lugares para o encontro e o convívio, que também abrigam diversos serviços públicos e equipamentos. Para isso, foram definidos espaços abertos e acessíveis que configuram outros contextos de interações livres e voluntárias entre as pessoas. De forma análoga ao que se dá nos âmbitos pedagógico e político-governamental, percebemos que a promoção do acolhimento está associada aí também à liberdade de agir e interagir. Em contraste, o segundo projeto de arquitetura, desenvolvido durante o governo de Gilberto Kassab (2006-2012), determinou espaços mais fechados e controlados para a construção dos outros 24 centros educacionais. Os espaços físicos dos CEUs, nos primeiros casos mais "abertos" e nos segundos mais "fechados", foram os que mais resistiram às eventuais tentativas futuras de transformação - até por conta dos custos e dificuldades de modificação dos edifícios em geral.

Os contextos de âmbito espacial constituem patamares privilegiados para observação de outros âmbitos, contanto que adotemos um estilo etnográfico de investigação disposto a relativizar fronteiras disciplinares e a seguir as conexões entre âmbitos distintos estabelecidas por nossos sujeitos de pesquisa. Os servidores envolvidos com os CEUs pensam ao mesmo tempo em problemas pedagógicos, administrativos e espaciais, entre outros; precisamos entender como suas 
ações empregam os materiais e técnicas diferentes, próprios de cada um desses âmbitos. Para explorar essa diversidade, o espaço será nosso ponto de ancoragem. Tal abordagem foi favorecida por minha atuação e experiência simultaneamente como arquiteto e antropólogo.

Fica claro que esta pesquisa pretende dialogar com públicos das mais variadas áreas, dentre eles antropólogos, arquitetos, educadores e cientistas políticos, esperando interessar também aos usuários e servidores dos CEUs em geral. Mesmo procurando escrever de uma forma acessível a todos, certas reflexões podem parecer complexas. Para que o leitor não desanime, vale sempre lembrar-se da recomendação de ler como se fôssemos observadores de baleias: mesmo quando perdemos algumas de suas aparições, seguimos observando sem nos preocuparmos. Outro fator facilitador da leitura está na relativa independência com que a conclusão e os capítulos podem ser lidos.

A questão central que orienta a pesquisa pode ser assim sintetizada: como os contextos representados aqui por espaços, normas administrativas, diretrizes pedagógicas, entre outros fatores - influem nas dinâmicas interacionais observadas nos CEUs, de forma a favorecer a promoção do acolhimento? Colocada desta forma, a pergunta revela que o interesse principal desta investigação coincide com aqueles de muitos dos sujeitos de pesquisa, ainda que as respostas encontradas variem, bem como a forma de aproximação ao problema. Em nosso caso, vamos questionar a relação entre acolhimento e liberdade de interações, que, como vimos, está contida nas propostas pedagógicas, políticas e arquitetônicas acima expostas. No primeiro capítulo analisaremos essas propostas, seus pontos em comum e suas divergências. No segundo e terceiro capítulos, direcionaremos a perspectiva etnográfica para observar como elas estão presentes no dia a dia dos centros educacionais - mas aí elas aparecem entrelaçadas com outras preocupações, práticas e produções de contexto que também merecem nossa atenção, e que podem até mesmo ajudar a iluminar caminhos alternativos para a promoção do acolhimento.

Outras pesquisas já se debruçaram sobre os centros educacionais, mas com perspectivas e objetivos diferentes. Os trabalhos de Pacheco (2009), Fasano (2006) e Guerreiro (2006) empregam um estilo de reflexão próximo ao da tradição marxista para uma análise crítica geral da política pública dos CEUs. Pacheco questiona a relevância dos centros educacionais para a promoção da educação escolar, critica a ênfase na arquitetura dos edifícios e acusa a predominância de interesses político-eleitorais em seus implementadores. Guerreiro considera que os espaços abertos do primeiro projeto arquitetônico dos CEUs podem favorecer contestações e resistências aos 
poderes hegemônicos, mas questiona a possibilidade de efetivar a inclusão social proposta pelos CEUs, pois considera que o capitalismo estaria fundamentalmente ancorado na produção de desigualdades. Fasano considera os CEUs favoravelmente como uma política que se opõe ao modelo de escola tradicionalmente implementado pelo Estado e apoiado pelas classes hegemônicas. Os trabalhos de Souza (2010) e Perez (2010), por sua vez, empregam um conjunto variado de teorias e métodos para defender a relevância da proposta inicial dos CEUs - inclusive de sua arquitetura. São interessantes sobretudo como relatos do envolvimento pessoal de seus pesquisadores com a criação e administração dos centros educacionais.

Ainda que essa bibliografia se mostre útil e importante, tomamos aqui outros rumos. Não se trata de abordar os CEUs para avaliar os modos como foram concebidos e implementados (embora possamos contribuir nessa direção), mas de mobilizar esses elementos em outro plano, para discutir o papel (real e potencial) da política das interações cotidianas na promoção do acolhimento. Outra particularidade desta pesquisa reside em suas escolhas metodológicas: além de adotar uma perspectiva etnográfica, realizou-se uma associação entre investigação e intervenção.

Em poucas palavras, a investigação etnográfica pressupõe um mergulho em profundidade na realidade estudada. Por essa perspectiva, o pesquisador evita carregar consigo explicações já consagradas e estabelecidas. Em vez disso, busca entender o universo pesquisado (no caso, os CEUs) a partir do ponto de vista e das ações das pessoas que os concebem, administram e frequentam. Em contraste com as pesquisas acima citadas, certamente relevantes, estamos menos preocupados em aperfeiçoar teorias já existentes e em empregá-las para avaliar os CEUs e mais interessados em caminhar com nossos sujeitos de pesquisa, retirando daí reflexões capazes de questionar e recolocar a forma como julgamos conhecer as coisas.

Também, por meio da etnografia, encaramos a realidade como algo de muita complexidade, que não pode ser conhecido objetivamente e que precisa levar em conta o próprio olhar do pesquisador - não para anular a sua influência, já que isto não é visto como possível ou desejável, mas para construir um conhecimento tanto do que é observado quanto de quem observa (o que inclui o olhar do pesquisador e também o do leitor). Por isso a etnografia não trabalha com a verificabilidade e sim com a plausibilidade, ou seja, não trabalha visando provar suas proposições ou encontrar relações necessárias entre fenômenos objetivos. Em vez disso, prefere convencer com a mobilização de probabilidades, gradações de certeza, indagações, alusões, provocações e suposições - enfim, construir um entendimento compartilhado que envolva o escritor, o leitor, os 
sujeitos de pesquisa e a própria realidade estudada. Mas esta construção compartilhada de conhecimento não faz da etnografia uma forma de investigação menos rigorosa que outras nem torna o pesquisador semelhante aos sujeitos de pesquisa, porque o primeiro trabalha com uma alternância entre o olhar próximo da realidade e o olhar distante, necessário para refletir sobre problemas específicos de forma sistemática.

Dito isto, a etnografia aqui realizada possui particularidades relacionadas à intenção de associar investigação e intervenção. Ainda que os etnógrafos estejam habituados a levar em conta os efeitos de sua investigação sobre a realidade estudada, poucas vezes intervêm nela e/ou tratam uma intervenção proposta como fonte de reflexão. Parte desta pesquisa procura realizar isto com o desenvolvimento de um projeto arquitetônico e de uma reforma para a biblioteca do CEU Butantã, procurando atender solicitações dos sujeitos de pesquisa.

De forma mais ampla, a intenção de contribuir para modificar a realidade estudada se traduz também em certas estratégias de sistematização de conceitos e de construção de texto: procuramos escrever de forma clara e acessível; assumimos a intenção de contribuir para a promoção do acolhimento, ainda que da forma específica explicada a seguir; e desenvolvemos uma tipologia enxuta e manejável de conceitos, que pode ser facilmente entendida, apropriada e modificada por aqueles envolvidos no cotidiano dos CEUs. Essa tipologia pode ser empregada para entender diversas situações cotidianas, adquirindo particularidades e colorações específicas em cada uma delas. Vamos observar como isso pode acontecer ao empregá-la no estudo dos CEUs Butantã e Vila Rubi, e de suas bibliotecas.

A associação entre investigação e intervenção obriga o pesquisador a assumir preferências e a defender cursos de ação, mas isso não quer dizer que suas análises estejam unicamente a serviço desses objetivos e que sejam prejudicadas por um excesso de desejos e expectativas. ${ }^{3}$ Em vez de trabalhar com uma fronteira rígida entre reflexão e ação (ou entre ciência e política), buscamos inspiração em Pedrosian (2011) para pensar em termos de deslocamentos no grau de envolvimento do pesquisador, admitindo variações no nível de comprometimento com a realidade estudada. Cada pesquisa tem possibilidades, limitações e propósitos que determinam esses deslocamentos, e o único critério geral parece ser o de não permitir que a intervenção prejudique a investigação ${ }^{4} \mathrm{e}$

\footnotetext{
${ }^{3}$ Vale a pena recordar o entendimento clássico de Weber: "sempre que um homem de ciência permite que se manifestem seus próprios juízos de valor, ele perde a compreensão integral dos fatos" (WEBER, 1970).

${ }^{4}$ Boa parte da literatura sobre pesquisa-ação (mais conhecida na língua inglesa por action-research) sustenta uma posição mais radical e, a nosso ver, bastante controversa, segundo a qual a pesquisa deve ser julgada em função de sua
} 
vice-versa - o que implica assumir posições de modo deliberado, controlado e explícito, tanto durante a escrita quanto na presença em campo. Neste trabalho, a defesa do acolhimento mantémse suspensa durante a maior parte das análises, mas toma a dianteira em momentos de conclusão para indicar certos cursos de ação, quando somos levados a dialogar mais explicitamente com nossos sujeitos de pesquisa. Além disso, empregamos a reflexão acerca dos contextos para analisar o projeto de reforma realizado na biblioteca do CEU Butantã.

$\mathrm{O}$ interesse em aproximar investigação e intervenção também nos levou a realizar uma análise comparada dos CEUs Butantã e Vila Rubi, no intuito de entender por que eles apresentam resultados tão diferentes na promoção do acolhimento. O CEU Butantã enfrenta dificuldades para essa promoção, mesmo tendo sido concebido e administrado por servidores relacionados à gestão Marta Suplicy (2001-2004), para os quais o acolhimento era prioritário, e mesmo tendo sido construído com espaços abertos e amplos, seguindo um projeto de arquitetura considerado de excepcional qualidade pelos arquitetos em geral. Comecei a frequentá-lo em 2010, durante minha graduação em Ciências Sociais, para realizar trabalhos disciplinares interessados em investigar a relação entre arquitetura e práticas cotidianas. Decidi continuar no CEU Butantã ao perceber que as dificuldades nele presentes parecem frequentes em muitos outros CEUs. ${ }^{5}$ Boa parte das mais de 75 visitas realizadas ao CEU Butantã desde 2010 concentram-se nos anos 2012 e 2013, e nelas acompanhei especialmente o cotidiano de bibliotecários, gestores e usuários. ${ }^{6}$

O CEU Vila Rubi, por sua vez, foi selecionado por ser visivelmente bem-sucedido na promoção do acolhimento, apesar de ter sido construído durante a gestão de Gilberto Kassab (2006-2012), período em que os CEUs já não estavam no centro da agenda municipal. Além disso, o CEU Vila Rubi tem áreas de convívio menores e mais difíceis de serem apropriadas, seguindo um projeto que não possui notoriedade no campo da arquitetura paulistana. Fica claro que este

capacidade de intervir na realidade: "The results of an AR [action-research] process must be judged in terms of the workability of the solutions arrived at" (GREENWOOD; LEVIN, 2007, p. 62). Além da variação entre investigação e intervenção, Greenwood e Levin falam da necessidade de maximizar a participação dos sujeitos de pesquisa. No entanto, é preciso considerar que isso nem sempre é inteiramente possível ou desejável, de modo que não há regra geral. A participação pode até ser maior ou menor nas atividades investigativas, e pode ou não equivaler àquela presente na intervenção.

${ }^{5}$ Dificuldades de promoção do acolhimento são relatadas por quase todas as pesquisas feitas sobre os CEUs. Para considerar o CEU Butantã como exemplo de outros, também me baseio em visitas e depoimentos colhidos sobre os seguintes CEUs: CEU Casa Blanca, CEU Aricanduva, CEU Paraisópolis, CEU Parque São Carlos, CEU Rosa da China, CEU Navegantes, CEU Paz, CEU Quinta do Sol, CEU Sapopemba e CEU Lajeado.

${ }^{6}$ Também acompanhei um pouco do cotidiano das escolas deste centro educacional, e neste caso vale mencionar que ministrei dois cursos de vídeo na EMEF, em 2011. Destaco ainda os projetos que venho desenvolvendo, a convite de meus sujeitos de pesquisa, para reforma dos espaços administrativos da EMEI, da EMEF, para o parquinho do CEI e para os escritórios da gestão - além do projeto de reforma da biblioteca, o único que se concretizou até o momento. 
CEU configura uma exceção entre os CEUs da cidade, e para encontrá-lo precisei analisar entrevistas realizadas nos 14 CEUs da Zona Sul por um mapeamento de redes culturais promovido pelo SESC Santo Amaro (DO VAL; PEREIRA, 2010). A partir de 2012 e sobretudo em 2013, realizei mais de 25 visitas a esse centro educacional, também dedicadas a acompanhar o cotidiano de usuários, bibliotecários e gestores. A quantidade menor de visitas deve-se a que os propósitos da pesquisa já estavam claros, e à facilidade em observar as práticas aí presentes. É importante observar que o propósito da análise comparada não é realizar uma avaliação geral dos dois centros educacionais, mas apontar para diferenças de acolhimento, contextos e dinâmicas interacionais. E mesmo no que se refere aos nossos interesses, se observarmos um CEU simplesmente como o oposto do outro, corremos o risco de empobrecer a caracterização dos dois.

Quanto às inspirações teóricas, esta pesquisa transita por uma bibliografia variada. Procuramos refletir sobre as práticas, as sociabilidades e as essencializações, observando fatores importantes para a constituição da política contida nas interações cotidianas e para a sua relação com problemas de espaço (PEREIRA, 2010; DALE; BURRELL 2010; CALDEIRA, 2000; LEITE, 2004; HERZFELD, 2008). De modo difuso e indireto, as noções de contexto propostas por esta pesquisa estão informadas pelo contato com as ideias de Latour (1989) e Deleuze e Guattari (1995), na medida em que esses autores propõem conceituações que atravessam aspectos da realidade comumente considerados como distintos. Mais especificamente, a tipologia de contextos que propomos é em parte tributária de discussões recentes da literatura sobre associações em Ciência Política (WARREN, 2010; HIRSCHMAN, 1970).

Feitas essas considerações, passamos à síntese do trabalho. O primeiro capítulo, intitulado "Projetos, interações e contextos: ensaiando um modelo de análise", começa apresentando a linhagem histórica de políticas públicas da qual os CEUs fazem parte. Em seguida passamos a analisar os projetos arquitetônicos, políticos e pedagógicos já esboçados nesta introdução para mostrar que a liberdade de ação e interação não se relaciona com a promoção do acolhimento da forma prevista. Observando certos vazios e incongruências presentes nesses projetos, a análise desenvolve uma tipologia de três tipos de contexto. Enquanto os projetos desenvolvidos durante a gestão de Marta Suplicy (2001-2004) podem ser classificados como propiciadores de contextos extensivos, as mudanças trazidas pelas gestões subsequentes - de José Serra (2005-2006) e Gilberto Kassab (2006-2012) - podem ser relacionadas à produção de contextos separadores. Em ambos os casos, encontraremos a presença de contextos intensivos, entendidos como um terceiro 
tipo de influência sobre as interações cotidianas. Ao final do capítulo realizamos uma síntese da tipologia de contextos, propondo entendê-la não como uma camisa de força, mas como um conjunto de ferramentas úteis para as análises subsequentes. Esse primeiro capítulo realiza uma discussão mais conceitual e utiliza poucos dados de campo, mas é preciso dizer que as reflexões nele contidas só foram possíveis em função da etnografia do cotidiano dos CEUs, que aparece nos capítulos seguintes. Leitores interessados numa discussão menos conceitual e mais acessível podem pular o primeiro capítulo.

O segundo capítulo, intitulado "Acolhimento, organização e segurança: desafios da gestão dos CEUs", redireciona a perspectiva etnográfica para o modo como os projetos e diretrizes analisados são implementados e posteriormente modificados no cotidiano da gestão dos CEUs Butantã e Vila Rubi. No CEU Butantã, observamos como o acolhimento é visto como incompatível com a garantia da organização e da segurança, e como a combinação da implantação, respectivamente, de contextos extensivos e separadores acaba por afastar usuários e funcionários, numa situação que parece ser frequente em vários outros CEUs da cidade. O CEU Vila Rubi pode ser visto como uma exceção entre os CEUs, mais bem-sucedido na promoção tanto do acolhimento quanto da segurança e da organização (valores que não são vistos por seus gestores e servidores como incompatíveis). Para isso, os gestores contam com uma combinação dos três tipos de contexto, com destaque para o extensivo.

O terceiro capítulo, chamado 'Entre 'usuários' e 'livros': investigação e intervenção nas bibliotecas", prossegue a análise comparativa dos dois CEUs por meio de uma etnografia realizada nas bibliotecas. Cada uma delas repete, à sua maneira, o diagnóstico de contextos, intenções e interações encontrado para os CEUs de que fazem parte. Neste caso, tratamos de uma quantidade menor e mais manejável de questões, que permitirão construir um quadro mais bem acabado do conjunto. A escolha por aprofundar nossa investigação nas bibliotecas tem a ver, dentre outros fatores, com o fato de se constituírem como extensivas e abertas ao público em geral. Nesse sentido, elas são semelhantes às gestões dos CEUs - assim, bibliotecas e gestões envolvem desafios semelhantes para o acolhimento, e serão contrapostas às escolas desses centros educacionais. O terceiro capítulo ainda conta com uma apresentação e análise da reforma realizada na biblioteca do CEU Butantã, da qual fui um protagonista.

Os três capítulos traçam um movimento que vai do geral ao particular, começando com problemas relativos aos CEUs de modo mais amplo, passando pelo nível das gestões e terminando 
em suas bibliotecas, de forma a mostrar como os problemas se repetem em distintas escalas. Fica claro que seguimos uma estratégia que podemos chamar de metonímica para sugerir uma maior abrangência de nossas constatações, na qual o estudo de uma parte da realidade indica questões pertinentes para muitas outras: o estudo de duas bibliotecas e de dois CEUs pretende indicar questões relevantes para todos os CEUs e seus diversos equipamentos; o privilégio de problemas de espaço permite apontar questões em outros âmbitos, como o político e o pedagógico, entre outros. 


\section{CAPÍTULO 1 - PROJETOS, INTENÇÕES E CONTEXTOS: ENSAIANDO UM MODELO DE ANÁLISE}

Este capítulo apresenta os projetos que deram origem aos CEUs e as intenções declaradas dos políticos, educadores e arquitetos que os conceberam. Mas as decisões de projeto não produzem exatamente as consequências previstas por aqueles que os criaram. Por meio de uma tipologia de contextos, vamos propor uma forma alternativa de entender os efeitos nas interações cotidianas causados pelas decisões de projeto. Utilizaremos projetos de arquitetura como fonte principal da discussão, derivando daí conclusões análogas que podem ser aplicadas aos âmbitos político-administrativo, pedagógico e temporal, entre outros.

Nossa discussão tem início com uma breve caracterização histórica dos CEUs. Prosseguimos definindo a noção de acolhimento, entendendo-a como uma das intenções mais importantes que orientaram a implementação dos centros educacionais, e como objeto privilegiado de nossa análise. Em seguida, consideramos projetos políticos e arquitetônicos como parte de um conjunto mais amplo de influências sobre as interações cotidianas, reunidas sob a noção de contextos. É importante observar que as discussões deste capítulo estão informadas principalmente pelo trabalho de campo realizado nos CEUs, e que os conceitos aqui propostos ficarão mais claros quando passarmos a empregá-los para entender o cotidiano dos CEUs Butantã e Vila Rubi, nos próximos capítulos.

\subsection{Caracterização dos CEUs}

Os CEUs inserem-se numa linhagem de políticas públicas em geral idealizadas por esforços conjuntos de educadores, políticos e arquitetos alinhados à esquerda do espectro político brasileiro. Ainda que apresentem diferenças importantes entre si, essas políticas buscam atender parcelas desfavorecidas da população com base na implementação de equipamentos que concentram, num só local, atividades e espaços dirigidos sobretudo à promoção da educação, mas também do lazer, do esporte e da cultura de um modo geral. Desse modo, beneficiam alunos de 
escolas e também moradores de áreas urbanas com altos índices de pobreza. ${ }^{7}$

Uma referência central para nossos propósitos é a atuação de Anísio Teixeira, uma das figuras mais proeminentes na história da educação no Brasil. Depois de passar por uma experiência de estudos nos Estados Unidos entre 1927 e 1929, Teixeira traz ao país um sistema de ensino conhecido como Platoon, em que alunos permanecem na escola por períodos de tempo prolongados. Os estudantes compõem grupos (em inglês, platoons) que se revezam na ocupação de espaços destinados a dois tipos de atividades pedagógicas: as "fundamentais" - relacionadas, por exemplo, ao ler, escrever e contar - e as "especiais" - voltadas à música, às artes, ao esporte, aos trabalhos manuais, e assim por diante. O educador brasileiro emprega o sistema platoon na construção de 28 escolas no Rio de Janeiro, entre 1932 e 1935, sobre as quais há muito poucas informações.

Experiência pedagógica de maior destaque acontece entre 1947 e 1951, quando Teixeira ocupa o cargo de secretário da Educação da cidade de Salvador, e desenvolve o sistema de ensino das escolas-classe/escola-parque. O sistema prevê um módulo composto por quatro escolas-classe e uma escola-parque: as primeiras abrigam salas de aula e atividades letivas com sentido "preparatório" para a vida em sociedade, e a segunda oferece diversas atividades de trabalho, artísticas, esportivas e recreativas. Nestas últimas predominaria, conforme as palavras do educador, "o sentido de atividade completa, com as suas fases de preparo e de consumação, devendo o aluno exercer em sua totalidade o senso da responsabilidade e ação prática" (DUARTE, 2009, p. 122). O sistema funciona com as turmas de alunos alternando-se na utilização dos espaços dos dois tipos de escolas, buscando aproveitar ao máximo as construções e recursos em geral. Percebe-se assim uma íntima integração entre concepção pedagógica e questões espaciais.

Apenas um desses módulos logrou ser construído, tendo como escola-parque o Centro Educacional Carneiro Ribeiro, até hoje existente na capital baiana. A presença dos arquitetos Diógenes Rebouças e Hélio Duarte não aparece apenas na elaboração do projeto arquitetônico desse centro (ANELLI, 2004), mas também no equacionamento do atendimento da demanda educacional da cidade, configurando a implantação de sete ou oito módulos de acordo com um notável raciocínio urbanístico e geográfico: o menor porte das escolas-classe permitiria que se localizassem em áreas mais caras de topo de morro, enquanto as escolas-parque, de grande

\footnotetext{
${ }^{7}$ O histórico abaixo foi elaborado com base nas seguintes fontes: Anelli (2004), Bastos (2009), Gadotti (2007), Guerreiro (2006), Suplicy (2008), Duarte (1973) e Perez (2010). Fontes específicas serão indicadas no decorrer do relato.
} 
tamanho, estariam localizadas nas áreas mais baratas, nas encostas dos vales de Salvador. O sistema escolas-classelescola-parque também foi previsto para ser implantado em Brasília, com uma escola-classe em cada superquadra e uma escola-parque para um grupo de quatro delas (DUARTE, 2009), mas não se expandiu para além de algumas unidades.

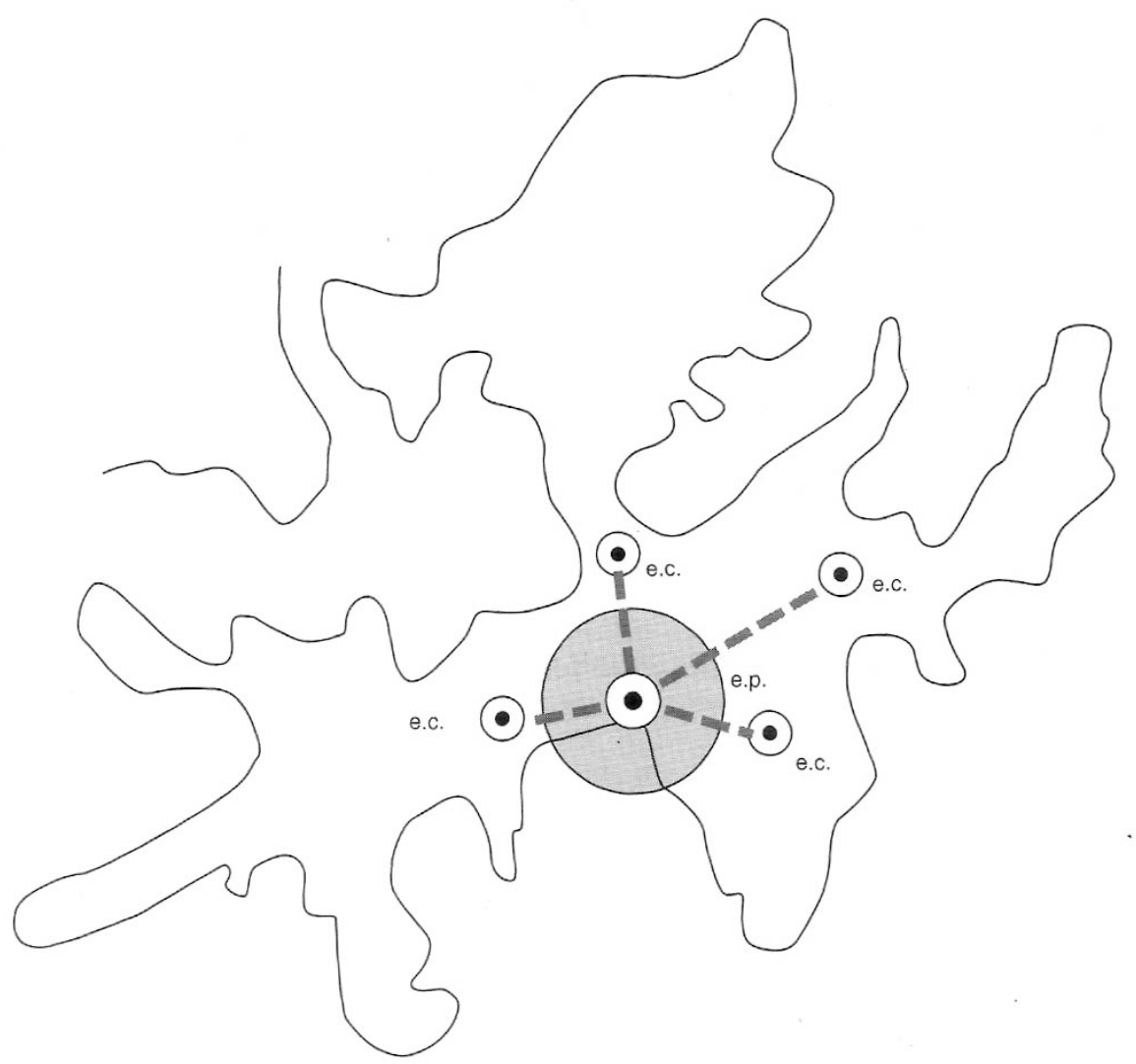

Figura 1 - Conjunto da Liberdade: Esquema da implantação do conjunto escolas-classelescolaparque na configuração topográfica local. Distância entre as escolas-classe e a escola-parque varia de 1 a 2 km. Crédito: Adaptado pela equipe Livi do original de Alice Seiko Matsumoto. Extraído de Duarte (2009, p. 111).

Dentre outras políticas públicas que se inspiraram nas propostas de Anísio Teixeira, ${ }^{8}$ merece

\footnotetext{
${ }^{8}$ Gadotti (2004) refere-se aos PROFICs (Programas de Formação Integral da Criança), desenvolvidos em 1986 pelo Estado de São Paulo, aos CIACs (Centros Integrados de Atendimento à Criança e ao Adolescente), criados durante o mandato presidencial de Fernando Collor de Mello em 1991, e os CAICs (Centros de Atenção Integral à Criança), construídos pelo governo de Itamar Franco entre 1992 e 1994. Uma referência longínqua está na construção de parques infantis entre 1935 e 1938 pelo Departamento de Cultura do Município de São Paulo, que na época era dirigido por Mário de Andrade. De acordo com Doria (2007) e Gadotti (2004), os parques proporcionavam atividades de lazer e cultura aos filhos de famílias operárias, mas não estavam relacionados à educação formal e a instituições escolares.
} 
destaque a dos Centros Integrados de Educação Pública, mais conhecidos como CIEPs. Construídos no estado do Rio de Janeiro durante os governos de Leonel Brizola (1983-1986 e 1991-1994), os CIEPs contaram com projeto arquitetônico de Oscar Niemeyer. Assim como ocorrerá com os CEUs, o uso de peças pré-fabricadas e a contratação de grandes empresas de engenharia garantiram custos e tempos de construção reduzidos, que viabilizaram a implementação de 408 unidades educacionais por todo o estado carioca.

A concepção político-pedagógica dos CIEPs foi desenvolvida pelo antropólogo e educador Darcy Ribeiro. Guerreiro (2006) procura entender as diferenças entre as propostas de Anísio Teixeira e dos CIEPs: se as práticas educativas da escola-parque seguiam a intenção de promover uma integração social e econômica dos mais pobres à sociedade brasileira, encurtando distâncias entre classes sociais, os CIEPs inserem-se num contexto pós-ditadura militar e são propostos por uma esquerda mais crítica com relação ao capitalismo e às reais possibilidades de integração social. A concepção pedagógica dos CIEPs ganha menor relevo em relação à preocupação com a assistência social voltada a uma população pauperizada; nesse sentido, o equipamento oferece atendimento médico-dentário, provê abrigos temporários para crianças em situação de abandono e promove atividades culturais interessadas em aproximar a escola das comunidades do entorno urbano.

Quanto ao problema que nos interessa de perto, relativo à política das interações cotidianas, é importante atentar para a implementação de mecanismos de gestão participativa nos CIEPs, visando envolver usuários do equipamento nos processos decisórios, normalmente reservados a servidores públicos. Talvez pudéssemos associar a esta abertura política, representada pela tentativa de implementar relações mais horizontais e voluntárias, uma abertura espacial, de forma semelhante à associação que proporemos adiante para os CEUs. Neste caso, a abertura espacial aparece na proposta de comunicar as salas de aula dos CIEPs por intermédio da construção de paredes divisórias de meia altura, com a intenção de induzir o convívio entre professores e alunos de salas diferentes (o problema será recuperado mais adiante).

Outra referência importante para a compreensão do projeto dos CEUs situa-se já no contexto paulistano, e volta a envolver Hélio Duarte. Depois de participar da experiência de Salvador, o arquiteto radica-se na cidade de São Paulo e passa a coordenar a produção arquitetônica da Comissão Executiva do Convênio Escolar, entre 1949 e 1954. O Convênio Escolar surgiu com a assinatura de uma parceria entre os governos estadual e municipal, que passam a incumbir-se, 
respectivamente, das tarefas de administração da rede escolar e de construção de novas unidades. Trabalhando para o município, arquitetos produziram uma quantidade notável de escolas que ainda hoje são referências no campo da arquitetura, mas que não foram concebidas com a participação dos educadores do âmbito estadual. Vê-se assim como as próprias condições políticas da época engendraram uma separação entre concepções pedagógicas e projetos de arquitetura.

A separação suscitou preocupações, ${ }^{9}$ mas continuou a marcar a história do município paulistano, e foi reavivada como uma das principais polêmicas que pautaram a construção dos CEUs. De fato, é importante notar que o Convênio Escolar está na origem da criação do Departamento de Edificações da Secretaria de Serviços e Obras do Município, o Edif - órgão responsável pelas reformas e construções de equipamentos públicos da cidade, e mais particularmente pelo desenvolvimento do primeiro projeto dos Centros Educacionais Unificados.

O mandato de Luiza Erundina (1989-1992) representa a primeira experiência do Partido dos Trabalhadores à frente do município paulistano, e é nesse período que o Edif desenvolve o projeto das Praças de Equipamentos Sociais (PES), de autoria dos arquitetos Alexandre Deliajicov, André Takiya e Wanderley Ariza. As PESs destinavam-se a reunir um conjunto de equipamentos que variava em função das necessidades locais, não contando com a padronização de serviços e atividades, nem com a obrigatoriedade da presença de instituições escolares, que caracterizaram posteriormente o projeto dos CEUs. Mesmo assim, as PESs podem ser consideradas antecessoras dos CEUs na medida em que antecipam diversos de seus aspectos, incluindo-se aí a preocupação com a abertura espacial, a adoção de técnicas de pré-fabricação e uma grande variedade e concentração de equipamentos e atividades. Muitos dos projetos das PESs contavam com escolas e foram desenvolvidos com alguma participação da Secretaria de Educação, na época encabeçada sucessivamente por dois educadores de renome, Paulo Freire (1989-1991) e Mário Sérgio Cortella (1991-1992). As PESs não foram concretizadas no governo de Luiza Erundina, permanecendo engavetadas durante os mandatos de Paulo Maluf (1993-1996) e Celso Pitta (1997-2000), até serem resgatadas como base para o projeto dos CEUs, na gestão petista de Marta Suplicy (2001-

\footnotetext{
${ }^{9}$ O próprio Anísio Teixeira procura reconhecer a importância que a arquitetura escolar teria para a educação e para o país num artigo escrito em 1951: "Reconheçamos com Pascal que o homem é feito de tal modo que, embora o sentimento anteceda o gesto na sua ordem natural, o gesto pode gerar o sentimento. No Brasil, estamos a procurar esse efeito. Façamos o gesto da fé para ver se a adquiriremos. A arquitetura moderna é esse gesto. Possam esses prédios escolares [...] comunicarem à educação e, pela educação, à existência brasileira, as suas finas e altas qualidades de inteligência, coragem e desprendida confiança no futuro" (apud BASTOS, 2009). O arquiteto Hélio Duarte observa em sentido oposto, num artigo de 1956: "Procurar no desenvolvimento de um plano arquitetônico razões últimas para uma melhoria educacional parece-nos contrassenso. Arquitetura é precioso coadjuvante, mas não a base da educação" (apud BASTOS, 2009).
} 
2004).

Os CEUs começam com a intenção de Marta Suplicy de encerrar o segundo ano de seu mandato com uma "proposta inovadora na área da educação". A ex-prefeita menciona como inspirações a escola-parque, os CIACs e os CIEPs, e fala de uma pesquisa realizada pelo Cenpec ${ }^{10}$ na Vila Brasilândia, no ano 2000, que apontava o desejo de adolescentes de periferia de contarem com "um lugar onde pudessem se encontrar e conviver, porque a violência os havia expulsado das ruas". A então prefeita associa a esse fato a observação do educador Paulo Freire, segundo a qual "não se pode aprender na feiura" - e observa: "[eu] só sabia, àquela altura, que tinha que ser um edifício bonito, feito de bom material, que agregasse várias atividades" (SUPLICY, 2008, p. 52).

Outras considerações, no entanto, extrapolam o foco em atividades educacionais voltadas ao público infantojuvenil e sugerem uma relação mais ampla entre CEUs e periferias urbanas. A exprefeita refere-se precisamente à intenção de "romper com aquela ideia de periferia como uma massa indistinta de regiões miseráveis", seguindo a tônica de uma gestão que se declarou, repetidas vezes, direcionada para a promoção da "inclusão social". ${ }^{11} \mathrm{O}$ excerto seguinte ilustra o ponto ao contrapor "feiura" e "belezura":

Aprendi com Paulo Freire[...] que o indivíduo precisa ter oportunidade de enxergar além da sua paisagem imediata, tem direito de conhecer a beleza e de entrar em contato com o mundo. "Tem que ter belezura", ele dizia. "Não se pode aprender na feiura. "[...] Eu queria mostrar que é possível outra vida. Não posso tirar 2 milhões de pessoas da favela e do cortiço, mas posso tirar a favela de dentro delas, pensava. (SUPLICY, 2008, p. 51)

Vemos como a conotação negativa e uniformizante das noções de favela, cortiço e sobretudo de periferia, empregadas por Marta Suplicy, aparecem como pano de fundo motivador da construção dos CEUs. Cabe apontar para a presença da dicotomia na própria escolha do nome $C E U$, na medida em que a imagem de um "céu" implica uma ideia inversa a respeito dos lugares de implantação desses equipamentos. ${ }^{12}$ Neste sentido, a periferia aparece como essencialização,

\footnotetext{
${ }^{10}$ Sigla para o Centro de Estudos e Pesquisas em Educação, Cultura e Ação Comunitária.

${ }^{11}$ Marta Suplicy associa a noção de inclusão social especialmente aos CEUs quando considera, em 2004, que a identidade de São Paulo poderia então ser construída como a da "cidade com maior programa mundial de inclusão social. No final da gestão, contávamos com os CEUs, que simbolizavam todos os projetos de inclusão social de forma integrada" (SUPLICY, 2008, p. 99).

${ }^{12} \mathrm{O}$ relato de como se chegou ao termo $C E U$ confirma esta observação: ele teria surgido com base no depoimento de uma "mulher bem pobre, de Rio Pequeno, que saía cedo de casa e se preocupava muito com os filhos, que ficavam sozinhos". Ao participar de uma pesquisa publicitária, a mulher teria dito: "se meu filho estudasse numa escola assim seria um paraíso". Luís Favre, marido de Marta Suplicy, que assistia ao depoimento junto com sua esposa,
} 
nos termos propostos por Herzfeld (2008, p. 49, 51 e 261): trata-se da criação de uma essência, de uma identidade cultural homogênea e coerente, a serviço da ação social. Investidas em discursos e práticas, as essencializações "fazem coisas com palavras", motivando, no caso, decisões fundamentais de governo, como a da implementação da política pública em pauta. Mais adiante as essencializações reaparecerão ensejando mudanças no projeto arquitetônico e organizando certos tensionamentos no âmbito político-partidário.

A noção de periferia suscita um desenho de política com objetivos mais amplos que o da educação escolar, relacionados ao chamado "desenvolvimento comunitário" - expressão que não adquire uma definição precisa, mas que remete ao atendimento da população de um modo geral, associando-o à implementação de mecanismos de participação popular na administração do equipamento público. ${ }^{13}$

Podemos então compreender as particularidades dos CEUs em relação às políticas públicas que mencionamos anteriormente: nenhuma delas distanciou-se tanto do programa escolar tradicional a ponto de oferecer uma gama tão diversificada de atividades e equipamentos, incluindo biblioteca, teatro, piscinas, padaria-escola, pista de skate, ginásio, salas para cursos diversos, entre outros espaços. Além disso, enquanto os projetos anteriores vinculavam-se exclusivamente às pastas da educação, os CEUs, tal como foram originalmente concebidos, previam articular também profissionais oriundos da Secretaria Municipal de Cultura e da Secretaria Municipal de Esportes, Lazer e Recreação, entre outras. Em reforço à noção de desenvolvimento comunitário, verifica-se ainda o empenho em fortalecer as instâncias participativas de gestão do equipamento: enquanto possuíam caráter consultivo no regimento dos CIEPs, adquirem agora a função deliberativa no regimento dos CEUs. ${ }^{14}$ No âmbito político, o

\footnotetext{
"imediatamente sugeriu o nome CEU (Centro Educacional Unificado), que dava conta de transmitir a ideia do conjunto que ele representava e do paraíso aludido pela senhora de Rio Pequeno" (SUPLICY, 2008, p. 53).

${ }^{13}$ Gadotti, educador que participou do esforço de concepção dos CEUs durante sua atuação no Instituto Paulo Freire, define a essência do projeto dos CEUs a partir da associação entre "escola pública" e "desenvolvimento comunitário". Maria Aparecida Perez, secretária da educação durante grande parte da gestão de Marta Suplicy, chega a associar o termo não só à participação política, mas também à melhoria do entorno urbano: "[t]oda a política educacional traçada objetivou o fortalecimento da escola pública associando-a ao desenvolvimento comunitário. Os CEUs completam a rede municipal de educação, agregando às escolas já existentes um espaço comunitário, de participação popular, de desenvolvimento local, tornando-se um equipamento além da sala de aula e do espaço escolar, pressupondo a melhoria dos espaços do entorno" (PEREZ apud DORIA, 2007).

${ }^{14}$ No regimento dos CIEPs, o chamado "Conselho Escola-Comunidade" é definido pelo artigo $26^{\circ}$ como possuidor de um "caráter consultivo, em trabalho de co-participação com a direção do CIEP, contribuindo para o processo de democratização do CIEP, através da integração Escola/Família/Comunidade, levantando e discutindo questões consideradas de interesse da comunidade escolar e propondo alternativas de solução, buscando um constante e efetivo entrosamento" (RIBEIRO, 1986). O Conselho Gestor será analisado mais adiante neste mesmo capítulo.
} 
projeto dos CEUs demonstra a ambição de promover uma integração horizontal entre órgãos públicos e entre poder público e cidadãos.

O projeto arquitetônico dos CEUs tem início com a redescoberta do projeto das Praças de Equipamentos Sociais, durante uma conversa entre o diretor do Edif e um dos servidores da gestão Marta Suplicy. A partir de então, o Edif passa a realizar alterações destinadas a transformar as propostas de PESs no projeto dos CEUs. Temos aqui outro indício de importância da relação CEU-periferia, se lembrarmos que as PESs eram compostas por um conjunto diversificado de equipamentos destinados a atender demandas variadas de seu entorno urbano; as unidades escolares só adquiriram centralidade com as modificações posteriores.

Em depoimentos de Alexandre Delijaicov, ${ }^{15}$ um dos arquitetos autores de ambos os projetos, transparece um raciocínio urbanístico não adotado oficialmente pelo governo, e que reforça o papel dos CEUs como uma centralidade urbana local. O arquiteto sugere a expressão "Centro de Estruturação Urbana" como significado alternativo para a sigla CEU, e refere-se à intenção de implantar 96 unidades de modo que cada distrito paulistano contasse com um local de encontro entre cidadãos e de concentração de serviços e equipamentos públicos, de forma equivalente ao papel desempenhado pelas praças centrais nas cidades do interior. Com isso, os CEUs passariam a se constituir como marcos simbólicos e identitários dos distritos, centralidades urbanas ou polos estruturantes da cidade "justamente onde ela se encontra mais desestruturada" (apud DORIA 2007, p. 132). Sob esse prisma, os CEUs são pensados como um projeto transformador da própria cidade.

Mais concretamente, a escolha dos locais que abrigariam CEUs buscou conciliar a disponibilidade de terrenos, a proximidade a bolsões de pobreza ${ }^{16} \mathrm{e}$ a áreas com presença de crianças e adolescentes punidos com internação na Fundação Estadual do Bem-Estar do Menor ${ }^{17}$, e o estabelecimento de distâncias convenientes em relação a outras escolas. A declaração de utilidade pública desses terrenos deu margem à construção de 21 CEUs durante a gestão de Marta Suplicy e de outros 24 já nas gestões subsequentes, de José Serra (2005-2006) e Gilberto Kassab (2006-2012). Nos depoimentos a mim concedidos, Delijaicov refere-se a indicações de outros 51 locais públicos, incluindo os Centros Esportivos do município, que poderiam ser adaptados para

\footnotetext{
${ }^{15} \mathrm{O}$ arquiteto concedeu-me três entrevistas em outuro de 2010.

${ }^{16}$ Com frequência cita-se o Mapa da Exclusão/Inclusão Social da Cidade de São Paulo (SPOSATI, 1996) como a referência mais importante para a localização dos CEUs.

${ }^{17}$ Atual Fundação Casa.
} 
abrigar outros CEUs, de modo a perfazer a quantia inicial de 96 unidades - muitas delas estão em fase de implementação no atual governo de Fernando Haddad (2013 em diante).

A preocupação com a inclusão social nessas intervenções nas "periferias" urbanas pauta os aspectos políticos e espaciais do projeto, mas não leva a uma concepção pedagógica específica, em contraste com o que observamos no projeto das escolas-classe/escola-parque. Partem daí as críticas mais frequentes aos CEUs, tensionadoras de debates no campo da educação e no cotidiano desses equipamentos, e exemplificadas pelas análises de Marcílio (2005) e Pacheco (2009). Em primeiro lugar, apontam-se problemas no plano pedagógico, chamando atenção para a inexistência de um programa de integração entre escolas convencionais do entorno urbano e os CEUs. Além disso, se o trabalho pedagógico das escolas no interior dos CEUs é muito semelhante ao de unidades educacionais convencionais, as diferenças - representadas pelo acesso privilegiado a recursos e espaços - suscitam uma divisão entre "pobres de primeira e de segunda linha" (MELLO apud MARCÍLIO, 2005, p. 352).

Muitas das críticas prosseguem para um segundo ponto, atingindo o privilégio à arquitetura e a desconsideração da qualidade da educação, na esteira da cisão entre projetos de edifícios e práticas pedagógicas já observada na experiência do Convênio Escolar. ${ }^{18}$ No caso dos CEUs, critica-se também o emprego de verbas originalmente destinadas à educação para arcar com os altos custos de construção de equipamentos pouco inspirados por objetivos educacionais. ${ }^{19}$ Estes dois pontos amparam a construção de uma crítica global aos CEUs, por exemplo, por Pacheco (2009), que os reduz a uma "falácia" predominantemente voltada a interesses políticos e eleitorais. Por outro lado, defensores do projeto dos CEUs, como a educadora Maria Aparecida Perez - exsecretária de Educação de Marta Suplicy -, justificam a falta de uma concepção pedagógica aludindo ao tempo reduzido disponível para tal, correspondente a um mandato municipal. Ao mesmo tempo, lançam mão de uma noção mais alargada de educação, representada pelo conceito de cidade educadora, para salientar a dimensão educativa de espaços e atividades não escolares sem que fique claro, no entanto, como essa abordagem efetivamente deve funcionar (PEREZ, 2010, e apud DORIA, 2007). O arquiteto Delijaicov, por sua vez, alude ao custo irrisório dos

\footnotetext{
${ }^{18}$ Críticas aos CIEPs também apontavam para uma cisão entre projetos arquitetônicos e pedagógicos. Gadotti (2004, p. 2) cita, por exemplo, as palavras do educador Lauro de Oliveira Lima: "o CIEP nunca se apresentou como um projeto pedagógico, mas como um prédio bonito do arquiteto Oscar Niemeyer: 'Pela primeira vez na história da educação se discute um prédio como proposta pedagógica'".

${ }^{19}$ Por exemplo, os cálculos de Marcílio (2005) procuram mostrar que as verbas empregadas na construção dos 21 primeiros CEUs poderiam ter sido utilizados na construção de 73 escolas convencionais.
} 
CEUs diante da proporção de gastos regulares com administração da rede existente. ${ }^{20}$

Fica claro que as críticas mais contundentes aos CEUs não operam na chave de uma avaliação mais equilibrada, capaz de reconhecer e discutir avanços parciais na promoção do acolhimento. Longe de pretender entrar num debate orientado por tentativas de avaliar, aprovar ou reprovar os CEUs em termos globais, este trabalho quer apontar para dinâmicas relativas às interações interpessoais nesses equipamentos, sublinhando desafios aí presentes para a promoção do acolhimento almejado. O estudo das interações é relevante para pensar projetos arquitetônicos, político-administrativos, pedagógicos e culturais, entre outros.

${ }^{20}$ Conforme as já mencionadas entrevistas concedidas a mim pelo arquiteto, em outubro de 2010. 


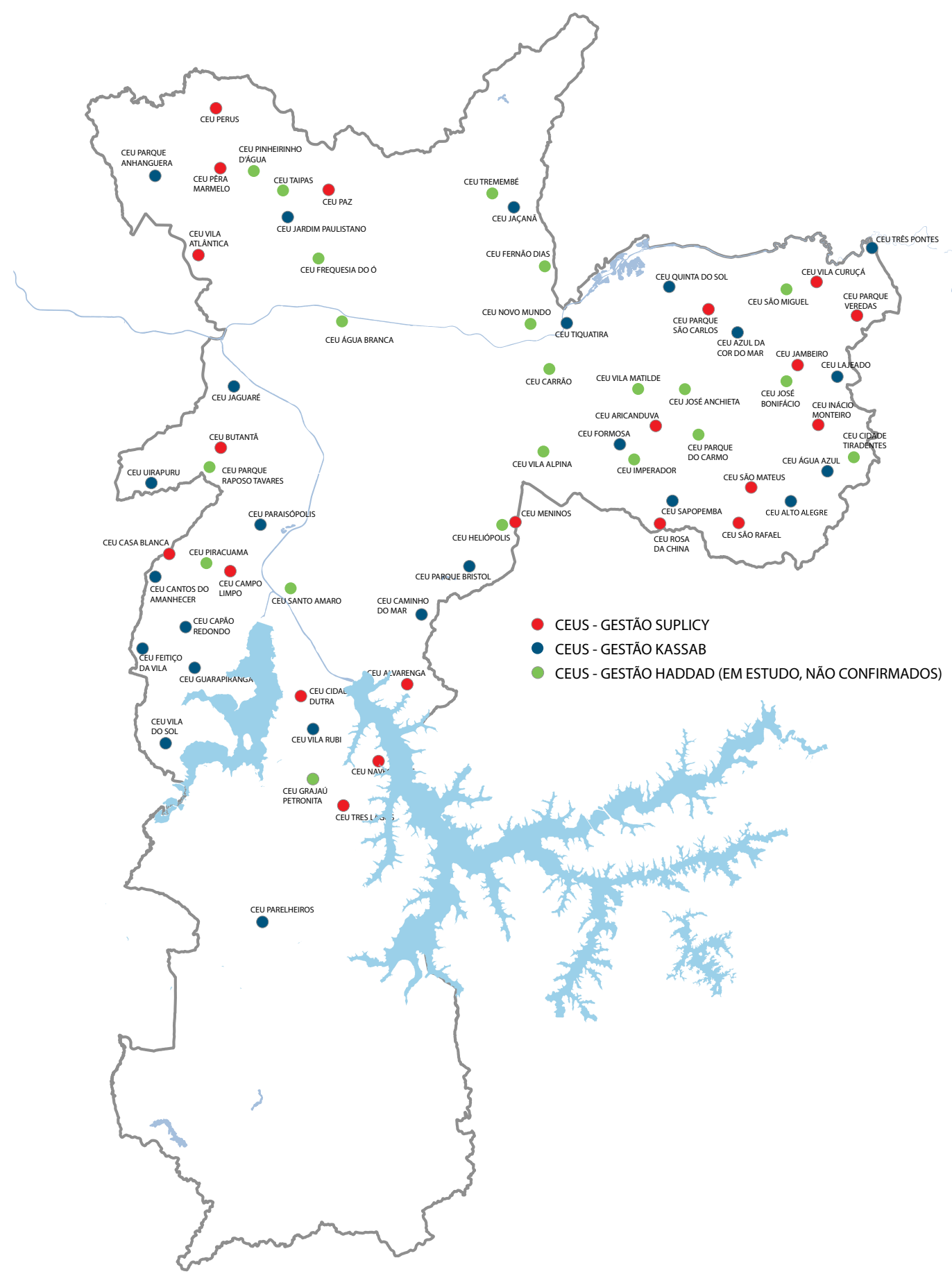

Figura 2 - Mapa de localização dos CEUs no município de São Paulo. 


\subsection{Acolhimento e contexto: definições preliminares}

Uma preocupação central para a política dos CEUs é aqui designada acolhimento. Em poucas palavras, propomos entender o acolhimento como um interesse difuso em (1) estabelecer relações de reciprocidade e diálogo com moradores de áreas desfavorecidas da cidade, e (2) diminuir desigualdades mediante a entrega de recursos e a prestação de serviços diversos, na forma de atividades pedagógicas, oportunidades de trabalho, espaços de encontro, eventos culturais e esportivos, serviços de saúde, entre outros.

O termo parece reunir satisfatoriamente uma série de preocupações que orientaram e ainda orientam a implementação da política pública dos CEUs em São Paulo, mas não deve ser confundido com elas. Da forma como o utilizamos, ele resulta de uma interpretação dos propósitos dos sujeitos de pesquisa, ainda que não seja muito distante de seus pontos de vista. ${ }^{21}$ Cabe assinalar que, se esta pesquisa compartilha do interesse em promover o acolhimento, isto se dá dentro dos moldes mais sistemáticos e isentos de uma pesquisa acadêmica. $\mathrm{O}$ acolhimento é observado ora com um olhar mais orientado para a descrição e a investigação, ora com um olhar mais preocupado com a intervenção e com a definição de linhas de ação para promovê-lo conforme discutido na introdução. Mas há ainda outros pontos a esclarecer.

É evidente que servidores públicos ligados ao Partidos dos Trabalhadores (PT) e pertencentes às instâncias superiores do governo Marta Suplicy (2001-2004) estiveram mais declaradamente comprometidos com o acolhimento. Mas isso não quer dizer que ele tenha sido ignorado em outros lugares e ocasiões. Ao falar em acolhimento, fazemos referência a uma preocupação que pode ser atribuída a iniciativas vindas de diferentes partidos políticos, mandatos municipais e escalões de governo. Também podemos considerar num mesmo conjunto profissionais dotados de formações diversas, contanto que estejam direcionados a beneficiar os moradores das proximidades dos centros educacionais, estabelecendo relações de diálogo com eles. Ainda que trabalhem com materiais e técnicas diferentes, e ainda que suas práticas e saberes não tenham as mesmas origens, eles podem ser aproximados por alinharem-se ao acolhimento. Neste sentido é que podemos buscar paralelos entre políticos que implementaram mecanismos de

\footnotetext{
${ }^{21}$ Nos termos propostos por Geertz (1983), a definição de acolhimento adotada aqui - assim como a definição subsequente de contexto - localiza-se entre os níveis êmico e ético.
} 
diálogo e gestão participativa, arquitetos que projetaram espaços abertos e centralidades urbanas, e educadores favoráveis a relações de simetria e cooperação entre professores e alunos, alinhados com as propostas de Paulo Freire.

A promoção do acolhimento pode envolver diferentes tipos de desafios, e esta pesquisa se concentra naqueles relacionados às interações cotidianas entre os frequentadores dos CEUs. Pretendemos observar como essas interações são influenciadas pelo que propomos chamar de contextos. Os contextos podem ser espaços, leis, projetos, diretrizes, entre outros aspectos da realidade que não podem ser facilmente transformados ou ignorados pelas dinâmicas interacionais que ocorrem no dia a dia de um centro educacional. Podemos dizer que as pessoas em geral estão frequentemente pensando em implementar contextos que sejam capazes de condicionar as interações cotidianas futuras, na direção definida por suas preocupações. Porém, os efeitos que os contextos produzem nas dinâmicas interacionais nem sempre correspondem às expectativas de quem os criou, e este capítulo vai tentar apontar para essas discrepâncias. Em termos mais específicos, dedicaremos atenção especial à relação entre a intenção de promover o acolhimento, manifestada por certos servidores públicos envolvidos com os CEUs, e a implementação de espaços abertos ao livre trânsito e ao convívio, associada à constituição de instâncias de gestão participativa do equipamento público.

Assim como observamos para a definição de acolhimento, nossa noção de contexto não corresponde exatamente ao ponto de vista de nossos sujeitos de pesquisa. Em primeiro lugar, a ideia de combinar condicionantes de tipos diversos não é estranha para muitos dos servidores envolvidos na implementação e administração dos CEUs. Por exemplo, projetos políticos e arquitetônicos são desenvolvidos para agregar influências diferentes na produção de um mesmo efeito: tanto a gestão participativa quanto os espaços físicos abertos podem contribuir para aumentar a liberdade de escolha das interações. Mas muitas vezes parece que uma leitura compartimentada dos campos de atuação e de conhecimento dificulta uma investigação mais profunda de seus modos de integração.

Em segundo lugar, procuramos entender a influência dos contextos de uma forma mais sistemática do que a empregada no cotidiano dos CEUs. Há dois requisitos para que um aspecto da realidade se constitua como contexto, tal como o entendemos aqui. O primeiro é que haja um poder de influência sobre as dinâmicas interacionais. Neste capítulo, a proposta é classificar as 
influências em três tipos básicos, denominando-as extensivas, intensivas ou separadoras. ${ }^{22} \mathrm{O}$ segundo requisito é condição para o primeiro, e refere-se à dificuldade ou mesmo à impossibilidade de alterar um contexto - se um contexto pode ser facilmente alterado, ele não constitui uma influência externa aos agentes, tornando-se irrelevante para nossos propósitos. Sendo assim, na equação das interações, um contexto é um fator que precisa ser considerado, enfrentado ou transposto. Ele pode até ser eliminado, transformado ou ignorado, mas isso envolve custos que desencorajam ou dificultam a tarefa.

Diversos tipos de custo podem ocorrer: se uma parede torna-se um entrave nas relações de trabalho, ela exige tempo e dinheiro para ser demolida; normas necessárias ao estabelecimento de hierarquias de trabalho requerem esforços de convencimento e tempo para serem implementadas; há também os custos representados por perdas de vantagens adquiridas, e neste sentido vínculos empregatícios podem induzir à continuidade de relações de trabalho. Finalmente, há custos mais sutis, representados por perdas de oportunidades de adquirir vantagens, como quando um sorteio de rifas numa festa incentiva as pessoas interessadas na premiação a permanecer no evento e interagir com outras pessoas.

Se um aspecto da realidade preenche apenas uma das duas condições supracitadas (capacidade de influenciar as interações e dificuldade de ser transformado), não chega a constituir um contexto. Um acordo verbal pode induzir duas pessoas a manter relações frequentes, mas se ambas podem desfazê-lo a qualquer momento, sem incorrer em qualquer tipo de custo, esta indução não existe de fato (falta aqui o segundo requisito). Uma norma legal pode exigir esforços e tempo para ser implementada, mas se não afeta as relações interpessoais, não satisfaz ao primeiro requisito e não é relevante para nossos propósitos.

\subsection{Extensividades}

Daremos início agora a um exercício de pensar o papel dos contextos na promoção do

\footnotetext{
${ }^{22}$ Convém explicitar que nesta pesquisa utilizamos os termos contexto e âmbito para designar coisas diferentes: o primeiro termo refere-se ao poder de influência sobre as interações e classifica-se nos três tipos supracitados; o segundo termo refere-se à natureza do fator que produz a influência, e classifica-se em espacial, legal, pedagógico etc. Utilizando os dois termos, podemos falar, por exemplo, em contexto extensivo de âmbito espacial, em contexto intensivo de âmbito legal e assim por diante.
} 
acolhimento, elegendo problemas de espaço como patamar privilegiado de observação de outros tipos de condicionantes das interações cotidianas. A discussão começa com uma apresentação do primeiro projeto arquitetônico dos CEUs, buscando associar seus espaços abertos à intenção dos seus idealizadores de favorecer o convívio e a livre escolha por interagir, o que nos leva a propor a noção de contextos extensivos ou extensividades. Em seguida procuramos deslocar esses nexos do âmbito espacial para os âmbitos legal e pedagógico, apontando extensividades na promoção de relações "horizontais" do primeiro regimento dos CEUs e na pedagogia da libertação proposta pelo educador Paulo Freire. Veremos como a intenção de garantir a livre escolha por interagir procurou ser associada à promoção do acolhimento; nesse momento, vamos preparar o terreno para discutir duas limitações importantes dessa relação, que serão esclarecidas com o desenvolvimento dos outros tipos de contexto.

Já observamos que, na escala urbana, o projeto dos CEUs (assim como seu antecessor, as Praças de Equipamentos Sociais) procurou entendê-los como polos estruturantes dos distritos da cidade de São Paulo. Na escala da arquitetura, a preocupação em relacionar CEU e entorno urbano desdobra-se em outras decisões importantes de projeto, a começar pela escolha das técnicas construtivas. A decisão de contratar grandes construtoras e de empregar elementos pré-fabricados padronizados permitiu que os primeiros 21 CEUs fossem construídos nos últimos dois anos do governo Marta Suplicy. ${ }^{23}$ No entanto, procurou-se associar essa estratégia à definição de técnicas convencionais de execução de instalações, alvenarias e caixilhos, no intuito de mobilizar a economia local com a contratação de cerca de 400 trabalhadores moradores das proximidades dos CEUs. A intenção de produzir um enraizamento no entorno urbano também suscitou a proposta de alugar imóveis próximos destinados a abrigar espaços de armazenagem e de apoio às empresas terceirizadas de limpeza e segurança - já que, de acordo com depoimento do arquiteto Alexandre Delijaicov, se a quantidade convencional de ambientes tivesse sido adotada, a área construída dos CEUs praticamente duplicaria, dificultando a efetivação da política pública. Os imóveis do entorno nunca chegaram a ser alugados e os CEUs ressentem-se até hoje da falta desses espaços. De qualquer forma, vemos que a elaboração do projeto arquitetônico tinha intenção de produzir

\footnotetext{
${ }^{23} \mathrm{O}$ sistema estrutural dos CEUs foi composto por pilares, vigas e lajes pré-fabricadas em concreto armado, em associação com estruturas metálicas, também pré-fabricadas, que foram empregadas em escadas de circulação e no edifício circular da creche, que mencionaremos adiante. As 21 unidades dos CEUs foram licitadas em seis lotes, com três ou quatro CEUs em cada uma. Cada CEU levou aproximadamente oito meses de obra para ser concluído. A menos que especificado em contrário, as informações deste tópico foram retiradas de três entrevistas que realizei com o arquiteto Delijaicov, em outubro de 2010.
} 
vinculações socioeconômicas e espaciais com o entorno urbano, reforçando o papel dos CEUs como centralidades na cidade.

Mas na escala do edifício o fator que melhor evoca a ideia de um relacionamento íntimo entre CEU e cidade é a definição de espaços abertos à livre circulação e ao convívio interpessoal. Antes de observarmos esta questão nos CEUs, é preciso sublinhar a importância da abertura espacial para os debates nos campos da arquitetura, dos estudos urbanos e mesmo de nossas democracias, pois ela é frequentemente relacionada ao valor da liberdade, como observa Teresa Caldeira (2000):

Imagens da cidade moderna são de muitas maneiras análogas às da comunidade política liberal, consolidadas com base em um contrato social entre pessoas idealmente iguais e livres. A ficção do contrato social baseado em um princípio de universalidade é radical - como aquela da cidade aberta - e ajudou a destruir a ordem social hierárquica dos estamentos feudais que a precedeu. (CALDEIRA, 2000, p. 305, grifos nossos)

Tendo em mente a importância dessa questão na reflexão atual em várias áreas, vamos observar como ela orienta a definição de diversos aspectos do primeiro projeto arquitetônico dos CEUs. Como vimos, este foi desenvolvido pelo Edif durante a gestão Marta Suplicy, tendo como autores os arquitetos Alexandre Delijaicov, André Takiya e Wanderley Ariza. No seguinte esboço explicativo da proposta podemos ver claramente como a interface entre CEU e cidade foi imaginada pelos arquitetos:

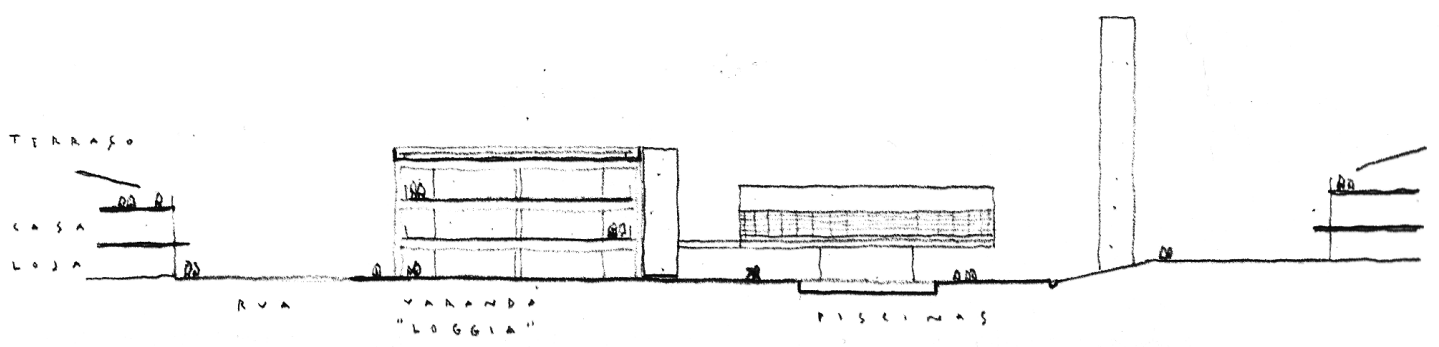

Figura 3 - Esboço do primeiro projeto dos CEUs. Arquivo Edif/SME. Extraído de Doria (2007, p. 142).

A imagem mostra grupos de pessoas distribuídos por diversos lugares do equipamento, das ruas e das casas do entorno. Proliferam os contatos visuais. A fluidez do espaço é salientada pela ausência de quaisquer barreiras ou muros entre o CEU e a cidade, de modo a borrar 
propositalmente seus limites.

A abertura espacial também pauta a concepção dos edifícios que compõem o primeiro projeto dos CEUs. Uma poética orientada para a procura de concisão e clareza inspirou a reunião de todos os equipamentos e espaços em apenas três grandes blocos. Apesar de serem padronizados para todos esses primeiros CEUs, os blocos foram previstos para serem combinados de formas variadas, de modo a se adaptarem às especificidades de cada localidade urbana. Os blocos receberam portanto projetos de implantação específicos para cada terreno, desenvolvidos fora do Edif por vários escritórios consagrados no campo da arquitetura paulistana. Com espacialidades e tamanhos muito diferentes, os três blocos testemunham a centralidade da preocupação com espaços abertos.

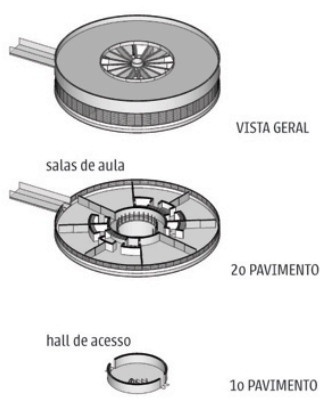

Figura 4 - Perspectiva do bloco do CEI, conforme primeiro projeto arquitetônico dos CEUs. 


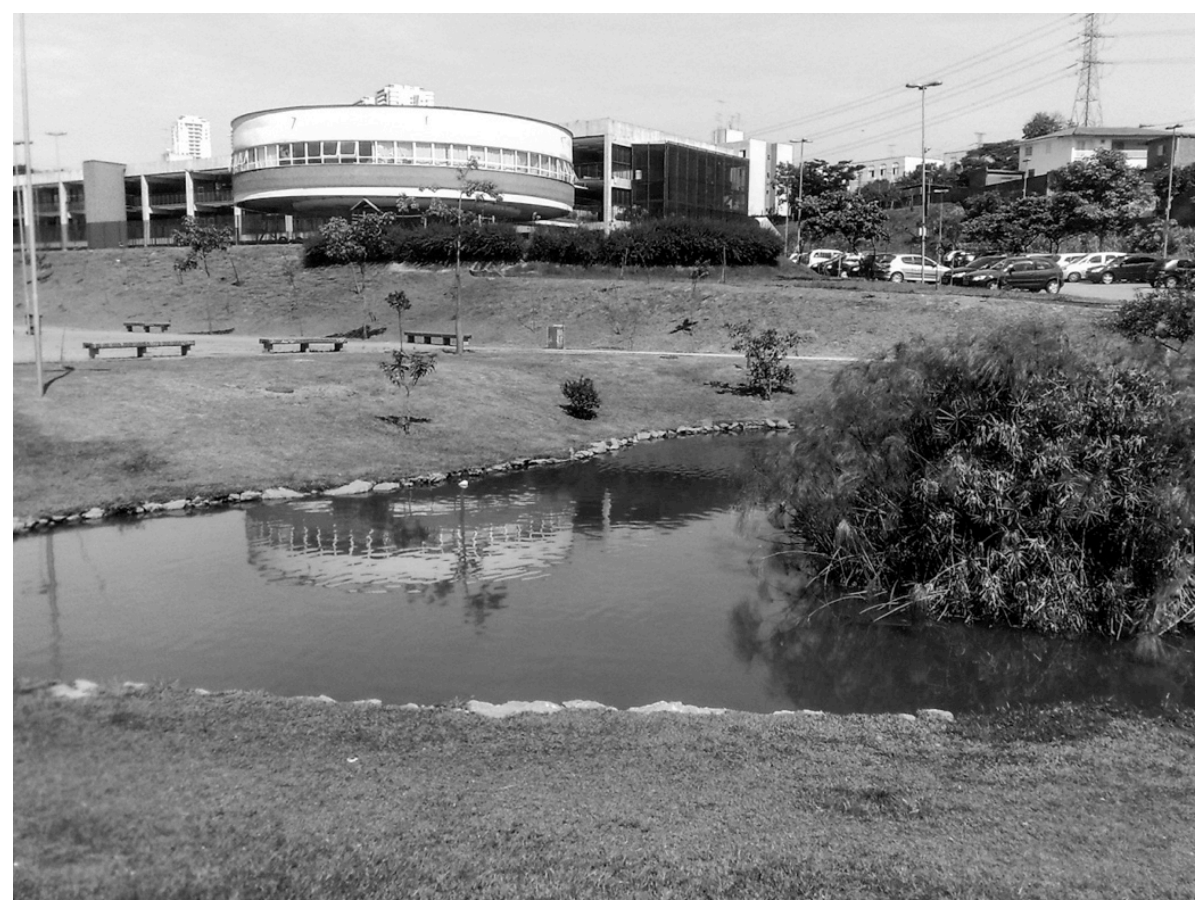

Figura 5 - Vista do bloco circular do CEI, no CEU Butantã.

O menor dos blocos corresponde a um volume circular destinado a abrigar parte das salas de aula do CEI - Centro de Educação Infantil. A construção desse edifício associa elementos estruturais verticais em concreto armado a vigas e tirantes metálicos configuradores de um balanço perimetral contínuo. De acordo com o arquiteto Delijaicov, o edifício evoca a forma de um disco voador, de uma árvore ou mais propriamente da gema de um ovo - tendo sido, inicialmente, parcialmente pintado na cor amarela para aludir ao início da vida. As salas de aula localizadas no perímetro de todo o primeiro andar possuem janelas com parapeitos de altura reduzida para que as crianças possam observar o mundo exterior desde uma posição privilegiada. As salas procuram evitar a sensação de confinamento, dando aos usuários a possibilidade de apropriarem-se visualmente das redondezas da escola. Este bloco também favorece os deslocamentos físicos das crianças através de conexões com o bloco educacional, onde se localiza o restante dos espaços do CEI. Além disso, uma passarela suspensa - representada na região central do esboço anteriormente apresentado - dá acesso direto a um pátio compartilhado com a EMEI, e ainda aos elevadores vinculados ao bloco educacional. 

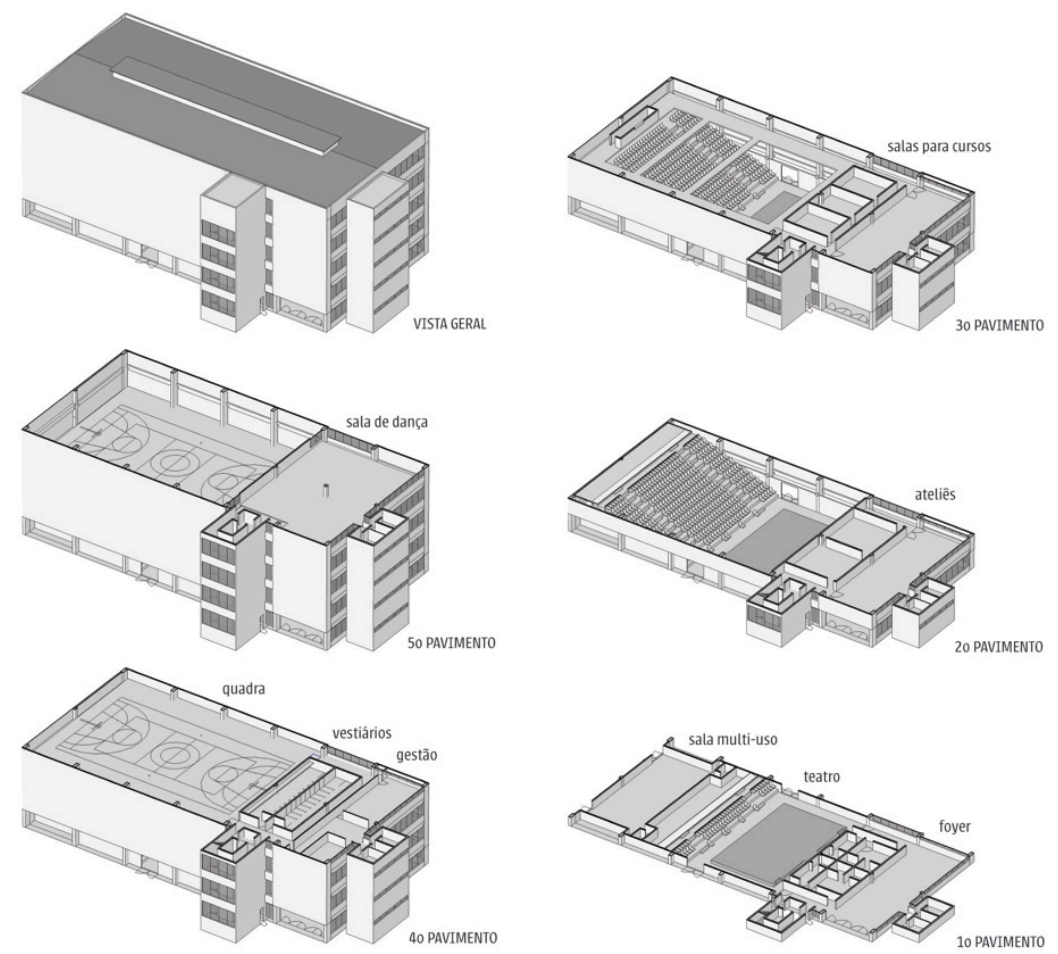

Figura 6-Perspectiva do bloco cultural - conforme primeiro projeto arquitetônico dos CEUs.

O bloco cultural, por sua vez, possui quatro andares ocupados pelos escritórios da gestão e salas de atividades e cursos, mas a maior parte de seu volume destina-se a abrigar dois espaços de grande porte: o teatro, no térreo, e, acima dele, um ginásio coberto. O aspecto fechado desse bloco, dotado de aberturas e janelas reduzidas, não corresponde à forma como foi desenvolvido pelo Edif. O projeto inicial propunha uma solução de teatro com arquibancadas retráteis, que poderia funcionar de modo integrado com as áreas exteriores do CEU graças à presença de aberturas generosas. Tratava-se de um teatro "experimental", relacionado à imagem de uma rua em que atores e públicos transitassem, e que foi inspirado na solução do Teatro Oficina, no bairro paulistano do Bixiga. 




Figura 7 - Teatro Oficina, com palco em forma de uma rua e arquibancadas suspensas. Extraído de Bardi e Elito (1999).

Nas palavras de Delijaicov, seria um "teatro de passagem, uma praça, uma ágora em que o edifício dialogasse com o seu entorno". ${ }^{24} \mathrm{Em}$ várias das versões iniciais do projeto de alguns CEUs (reproduzidas em Guerreiro, 2006), o interior do teatro recebe circulações laterais elevadas que servem como mezaninos para assistir às apresentações, e ainda prolongam-se ao exterior do edifício. Com isso, configuravam-se passarelas suspensas conectadas aos corredores do bloco educacional, deixando clara a intenção de favorecer o livre trânsito e o contato entre pessoas e atividades muito diversas.

${ }^{24}$ Apud Santos, 2003 (publicado no diário Folha de S. Paulo de 15 de maio de 2003). 


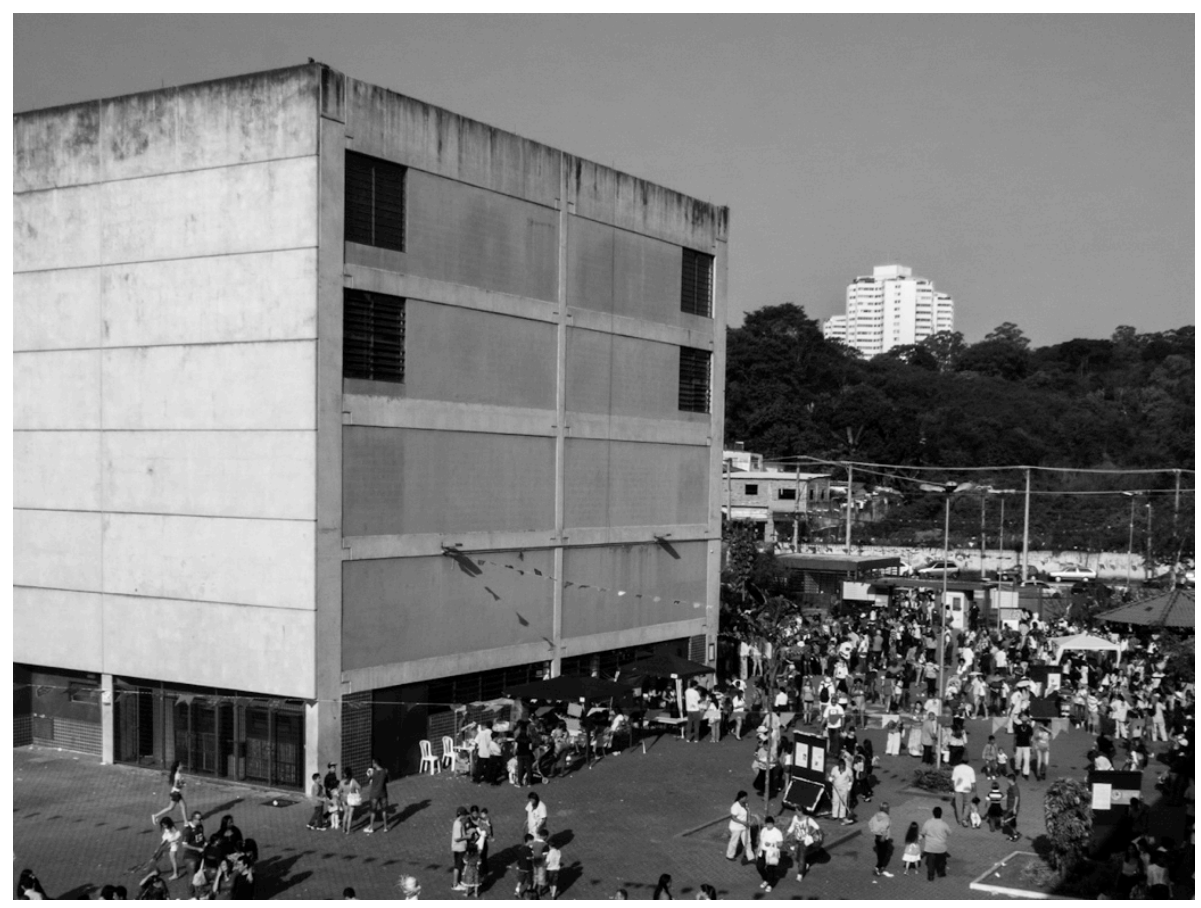

Figura 8 - Vista do bloco cultural do CEU Butantã.

No entanto, e mesmo após o início das obras dos CEUs, o espaço do teatro foi totalmente transformado, recebendo um palco italiano tradicional e uma arquibancada escalonada e fixa que implicaram numa interrupção da continuidade entre interior e exterior, eliminando também a presença das passarelas. A justificativa da mudança passa pelos receios com a manutenção das arquibancadas retráteis e com a provável dificuldade de apropriação da solução "experimental" por parte de grupos de teatro, mas deve-se principalmente a críticas que passaram a associá-la a uma ideia de precariedade. Ao comentar a decisão, Marta Suplicy guia-se mais uma vez por “essencializações” (nos termos de Herzfeld, 2013) contidas em reclamações que teria recebido da população:

achavam que estávamos projetando "teatros de pobre". Quis saber o que era um "teatro de rico". A população queria palco italiano, cortina e poltronas estofadas, como se via na televisão. Tínhamos proposto teatros de arena, com bancos móveis em torno do espaço central. É claro que essa reviravolta encareceria brutalmente o projeto, mas não tive dúvida. Se uma das metas era resgatar a autoestima daquela população, não seria $o$ custo que iria impedir o resultado. (SUPLICY, 2008, p. 57) ${ }^{25}$

${ }^{25}$ Mais informações em Doria (2007, p. 148), Guerreiro (2006), Santos (2003) e Frateschi (2003). 
Por conta dessas reviravoltas do bloco cultural, o bloco educacional é o que mais concentra espaços abertos. Delijaicov observa que esse edifício possui o porte de um transatlântico, podendo ainda ser entendido como o volume principal do CEU: dele partem ligações com atividades e espaços anexos, representados pelos outros blocos e também pela caixa de elevadores, pelas piscinas e por quaisquer outras adições que possam ser futuramente propostas. Em seus pavimentos superiores o edifício abriga as escolas do $\mathrm{CEU}^{26}$ e no térreo, um conjunto de equipamentos voltados ao público em geral: biblioteca, telecentro, padaria-escola e vestiários das piscinas, além da maior parte das dependências do CEI, incluindo salas de aula.



Figura 9 - Perspectiva do bloco educacional - conforme primeiro projeto arquitetônico dos CEUs.

\footnotetext{
${ }^{26}$ Centro de Educação Infantil (CEI), para crianças de 0 a 3 anos; Escola Municipal de Educação Infantil (EMEI), para crianças de 4 e 5 anos; Escola Municipal de Ensino Fundamental (EMEF), que atende crianças de 6 a 13 anos. No período noturno, as turmas de Educação de Jovens e Adultos (EJA) ocupam salas de aula da EMEF, e em muitos CEUs parte dessas salas também é ocupada pelas Escolas Técnicas Estaduais (ETECs), que ministram cursos profissionalizantes. Finalmente os telecentros dos primeiros CEUs vêm sendo adaptados para abrigar a Universidade Aberta do Brasil (UAB), resultante de parcerias entre a esfera federal e estados, municípios e universidades, com o propósito de oferecer cursos de graduação e pós-graduação a distância, em regime semipresencial.
} 
Podemos ver que o projeto distancia-se de uma solução mais convencional de escola, em que um corredor de circulação central dá acesso a salas em ambas as suas laterais: as escolas contam com corredores duplicados, posicionados nas laterais do edifício de modo a abrir um de seus lados para a paisagem urbana circundante, e o outro a salas de aula amplamente envidraçadas. Podemos ver isso no esboço explicativo anteriormente apresentado e na imagem abaixo:

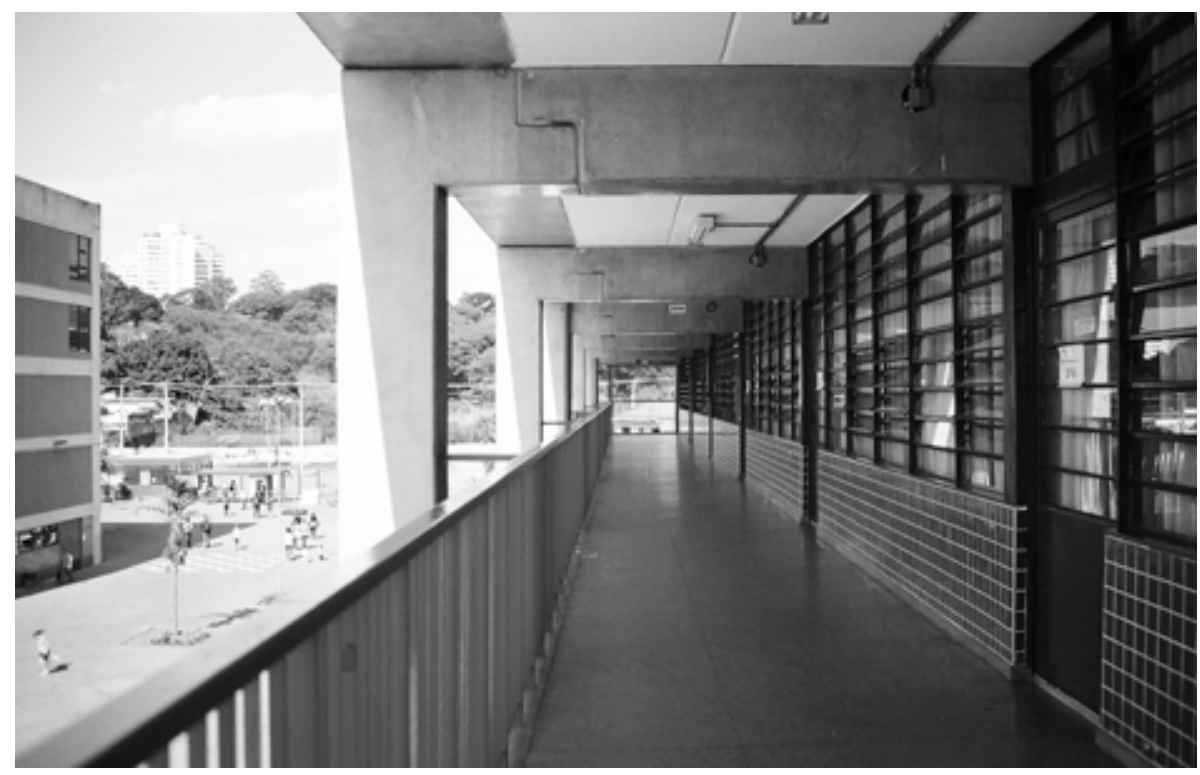

Figura 10 - Corredor de circulação da EMEF, com vista para o interior das salas de aula e para a paisagem urbana circundante.

Segundo Alexandre Delijaicov, a ideia dos arquitetos e educadores envolvidos com o projeto era permitir que os pais, e mesmo os frequentadores dos CEUs em geral, tivessem acesso a esses corredores, podendo observar os trabalhos dos alunos e manter contato cotidiano com os professores. Além disso, havia a possibilidade de transitar por entre os três blocos do CEU através das já mencionadas passarelas suspensas, que foram mantidas na solução final apenas na conexão com o volume circular do CEI. A possibilidade de circulação pelos pavimentos superiores do edifício, e através dos espaços escolares, é evidenciada pela não previsão de portões ou outras formas de controle de acesso entre a EMEI e a EMEF, e entre os pavimentos. Nesse sentido, os corredores são qualificados por Delijaicov como "calçadas" urbanas suspensas - como uma extensão da cidade ao interior do CEU - e, extrapolando a noção de passagem, como "varandas" a partir das quais é possível observar e ser observado. 
Então o cidadão com seis meses vai ter o contato visual de trocas com um cidadão de oitenta anos, se esse cidadão de oitenta anos sai da hidroginástica e pode ir em direção ao vestiário que está junto à escola central, pode passar junto às janelas do berçário para ver as crianças. Sempre é um divertimento, uma vitrine, do mesmo modo que a sala ambiente pode ser uma vitrine da geografia, das artes, ciências e história... o berçário, por exemplo, parte do berçário tem essa intenção, você vê as criancinhas com aqueles brinquedos, né? ${ }^{27}$

Esta descrição põe em relevo a relação entre contextos de âmbito espacial e as intenções que motivaram a sua definição. Nosso propósito é apontar para certas discrepâncias entre as intenções que presidiram a criação de espaços abertos nos CEUs e os efeitos desses espaços na constituição das dinâmicas interacionais. A abertura espacial foi entendida como uma forma de efetivar o convívio e o encontro entre públicos diversos, e isso, como observamos no início, encontra ampla afinidade com imagens de nossas democracias contemporâneas. No entanto, a defesa da abertura espacial traz embutida uma série de valores e ideias diferentes, que tendemos a considerar favoravelmente e de forma unívoca, dificultando uma investigação sistemática sobre a relação entre contextos e interações cotidianas.

\footnotetext{
${ }^{27}$ Depoimento prestado a mim por Deliajicov em outubro de 2010. Outro relato ilustrativo do mesmo arquiteto foi colhido por Souza: "A arquitetura dos CEUs foi concebida para promover o encontro entre as pessoas, o encontro da população com o Estado, enfim, deixar fluir a troca de olhares, o conhecer e ser conhecido, e por este motivo que um dos elementos arquitetônicos que mais chama atenção nos edifícios dos CEUs é a transparência através de amplas áreas avarandadas que dão acesso às salas de aulas e demais espaços dos CEUs, vem da ideia de alpendre do interior, um local onde as pessoas se locomovem e sobretudo param para conversar e observar ao redor" (SOUZA, 2010, p. 3435). Finalmente, observações interessantes aparecem também em Doria (2007, p. 142).
} 


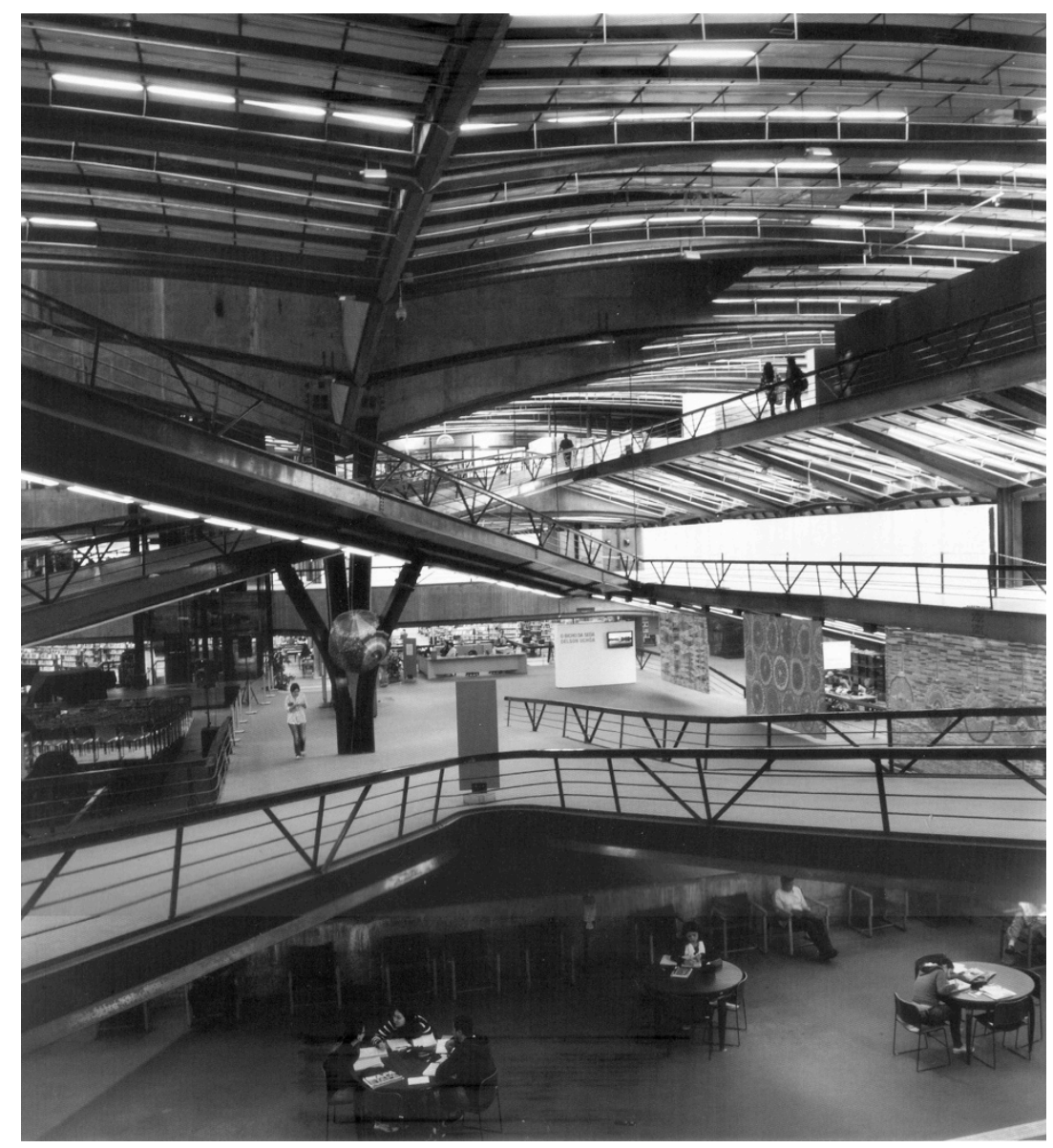

Figura 11 - Centro Cultural São Paulo, com caminhos diversos e ausência de portas de entrada. Crédito: Cristiano Mascaro. Extraido de Serapião (2012, p. 135).

Em primeiro lugar, observamos a associação entre abertura espacial e efetivação de encontros interpessoais. Tal associação ganha o sentido de convívio e de relacionamento harmônico entre públicos diversos. Esta ideia não está presente apenas nos CEUs, podendo ser observada em várias defesas do caráter público dos espaços urbanos, e mais particularmente em modos de pensar a cidade existentes no campo da arquitetura. É o que está contido, por exemplo, nos comentários a respeito de uma importante obra da metrópole paulistana, o Centro Cultural São Paulo, construído entre 1976 e 1982 na Rua Vergueiro, no bairro do Paraíso. Ao analisar o edifício, o editor e crítico de arquitetura Fernando Serapião associa a ausência de portas de entrada e as diversas possibilidades de adentrar o edifício à liberdade e à democracia, lembrando uma frase de Luís Telles, um dos autores do projeto: "Fizemos um espaço para reunir pessoas, um edifício democrático, elaborado em plena ditadura militar!" (SERAPIÃO, 2012, p. 62-64). Na ocasião de um documentário sobre o mesmo edifício (CENTRO CULTURAL SÃO PAULO, 
2013), o arquiteto Telles afirma em direção semelhante: "Quem vem aqui [Centro Cultural São Paulo] é pra se encontrar. E esse é que é o grande lance do espaço público. [...] Ou a gente abraça as pessoas, ou jamais se faz um espaço público". ${ }^{28}$

Em segundo lugar, a abertura espacial também parece aludir a um certo sentido de reciprocidade política, ou de simetria de poder entre as pessoas. Temos aqui a referência a uma concepção de igualdade e a um valor que constitui um dos pilares de nossas democracias contemporâneas, além de compor a dimensão política da definição que demos para o acolhimento. A relação entre abertura espacial e simetria de poder parece mais compreensível quando a colocamos em contraste com outra relação, talvez mais evidente, entre fechamentos de espaço e hierarquias de poder.

$\mathrm{Na}$ realidade, a crítica aos fechamentos de espaço representa a outra face da moeda que atribui uma conotação positiva aos espaços abertos. Uma ampla literatura procura relacionar o cerceamento da vida pública em nossas sociedades contemporâneas à proliferação de fechamentos e controles de espaços da cidade, que reduzem as possibilidades de intercâmbio entre ideias, valores e experiências (CALDEIRA, 2000; BERMAN, 1986; JACOBS, 1961; SENNET, 1974). Interessa mais diretamente à nossa discussão o fato de que os fechamentos são muito comuns ao universo das escolas. Nesse sentido, o primeiro projeto dos CEUs aparece como um dos raros exemplos de promoção da abertura espacial em espaços educacionais. ${ }^{29}$ Grande parte das escolas de São Paulo assiste a esforços interessados em erguer altos muros entre espaços internos e ruas externas, instalar grades, portões e trancas. A associação entre escolas e "presídios" é frequente, como se pode deduzir do trabalho de Pereira (2010), e mesmo no CEU Butantã vi o termo ser usado entre alguns alunos da EMEF para criticar a implementação de dispositivos de controle

\footnotetext{
${ }^{28}$ Outro exemplo ilustrativo pode ser encontrado em Orenstein e Andrade (2014): "Os momentos mais agradáveis da vida urbana acontecem em espaços públicos [...] E talvez sejam também os momentos mais importantes, pois é aí que pessoas diferentes se conhecem e conversam, num convívio que estimula a tolerância e o aprendizado". Nestes exemplos, a abertura espacial associa-se à ideia do convívio; mais adiante ela será relacionada à produção de conflitos, que no entanto também são vistos como positivos para a democracia. Souza (1973, p. 69-73) também atribui efeitos precisos e positivos à abertura espacial dos CEUs, propondo qualificá-la como "contrapanóptica", relacionada a uma atitude protetora e a uma amplificação dos contatos entre as pessoas. Essas ideias são as que apostam mais alto no poder de influência do espaço na política. Nos próximos capítulos observaremos que a capacidade de o espaço influenciar as interações cotidianas nunca se mostrou tão efetiva ou precisa na etnografia do cotidiano dos CEUs Butantã e Vila Rubi. Esta pesquisa desenvolve a hipótese de que o poder dos contextos sobre as interações cotidianas é muito mais difuso e ambíguo do que geralmente se imagina, sem que deixe de ser relevante.

${ }^{29}$ Outros exemplos comumente discutidos entre educadores interessados nesta questão: Escola da Ponte, na cidade do Porto, em Portugal; EMEF Desembargador Amorim Lima, no bairro do Butantã, em São Paulo, declaradamente inspirada nas práticas da escola portuguesa; EMEF Campos Salles, localizada na favela de Heliópolis, também na capital paulista. Todas essas escolas são simpatizantes da pedagogia da libertação de Paulo Freire e possuem salas de aula integradas, desprovidas de paredes internas ou dotadas de paredes removíveis.
} 
como esses.

Reconhecida a importância desses debates e reflexões, gostaria de alertar contra a tendência de associação imediata entre características de espaço e efeitos políticos precisos, e também para a tendência de produção de dicotomias como aberturas positivas versus fechamentos negativos. Tais associações e contraposições tendem a ocorrer quando o âmbito do espaço é visto de modo preponderante e isolado em relação aos demais, como mostra uma pesquisa sobre ambientes corporativos empreendida por Dale e Burrell (2010). Os autores reconhecem a existência de uma associação tradicional entre fechamentos de espaço, de um lado, e produção de hierarquia e status entre funcionários e executivos, de outro. Porém, falam de tendências recentes, propaladas por consultores e arquitetos, em promover ambientes de trabalho mais abertos, transparentes e homogêneos, livremente acessíveis a todos os funcionários. O espaço aberto associa-se facilmente a práticas discursivas que procuram conferir às empresas um sentido de "comunidade", sentido este que supostamente produz mais cooperação e comunicação entre seus empregados. A conclusão dos autores é a de que, em última instância, a cooperação e comunicação ampliadas acabam servindo aos interesses das próprias empresas. $\mathrm{O}$ espaço aberto e a circulação ampliada facilitam o monitoramento e o controle das atividades por parte dos supervisores, assim como acontece em prisões, em linhas de produção fabril e no famoso panóptico estudado por Foucault (1975). Além disso, o significado positivo geralmente atribuído ao espaço aberto ajuda a convencer os empregados de que as empresas são comunidades em busca de um objetivo comum - o que, no entender dos autores, representa um engodo capaz de reforçar relações de exploração.

Ainda que a associação entre assimetrias de poder e espaços fechados seja frequente, este exemplo deixa claro que o espaço aberto não pode ser imediatamente associado à produção de relações simétricas de poder entre as pessoas. O estudo também mostra que, quando observamos apenas um tipo de influência - no caso, de âmbito espacial -, corremos o risco de perder de vista o quadro estabelecido pelas relações entre distintos âmbitos - relações de reforço, de contraponto, de sobreposições parciais etc. Na análise mencionada, o espaço aberto aparece como um atenuante duvidoso somente porque contraposto ao estabelecimento de relações hierárquicas construídas no âmbito dos vínculos empregatícios. De modo análogo, podemos supor que fechamentos de espaço podem reforçar o poder de grupos subalternos, contribuindo para a construção de relações interpessoais mais simétricas.

Enfim, se a abertura espacial parece estar longe de se associar a relações de convívio e 
harmonia, ela parece mais próxima da produção de simetria de poder. No entanto, fica claro que isso não pode ser generalizado, devendo ser verificado caso a caso.

Há ainda um terceiro efeito comumente relacionado à presença de espaços abertos, bem menos controverso do que os anteriores, e que se refere à possibilidade da livre escolha de agir e interagir - e aqui tratamos não tanto de questões de igualdade, mas de liberdade. De fato, quando projetamos ou pensamos os espaços, imaginamos possibilidades de deslocamento das pessoas, e a partir daí surgem diversas possibilidades de encontro e de relações entre elas. O contrário também é verdadeiro, ou seja, pensamos os espaços para definir as relações possíveis entre as pessoas. Em função disso, limitamos acessos e possibilidades de movimento - mas neste segundo caso a qualidade das relações, incluindo-se aí igualdades e hierarquias, tende a envolver um conjunto maior de âmbitos, extrapolando o espaço. Posta desta forma, a liberdade de agir e interagir aparece como um problema mais passível de ser esquadrinhado, e ao mesmo tempo mais ambíguo quanto às consequências que é capaz de produzir nas interações cotidianas (a julgar, por exemplo, pela análise citada de Dale e Burrell). É sobre ela que propomos nos debruçar neste momento.

Como a abertura espacial pode facilmente ser associada a sentidos tão diversos quanto os de convívio, simetria de poder e liberdade, e como o conjunto desses valores tende a ser considerado invariavelmente como positivo, consideramos prudente alterar os termos do debate. Nessa direção, propomos falar em contextos extensivos para fazer referência a todo tipo de contexto que assegure uma ampla liberdade de agir e interagir. Nesses contextos, as interações tendem a ser voluntárias, dependendo predominantemente do mútuo interesse e da vontade das pessoas. O termo extensivo é oportuno também por não evocar uma característica espacial concreta, já que, como veremos adiante, a abertura espacial pode não se relacionar à liberdade de interações.

Sendo mais abstrata, a ideia da extensividade pode ainda ser transposta do âmbito espacial para outros âmbitos. Vamos testar a noção, empregando-a numa breve apresentação do primeiro regimento interno dos CEUs, principal documento constituidor de sua realidade jurídica e institucional. Promulgado em 30/11/2004 durante a gestão Marta Suplicy (SÃO PAULO, 2004), o primeiro regimento define condicionantes das interações propositalmente análogos aos que vimos para o âmbito do espaço. Mas o âmbito jurídico apresenta particularidades que o diferenciam do espacial. Ele determina atribuições e competências específicas a cada entidade considerada, e por isso possui uma capacidade maior do que o espaço para definir hierarquias e igualdades. É preciso lembrar, também, que as leis são elaboradas predominantemente para definir relações obrigatórias 
e necessárias, mostrando-se menos capazes de falar das que são opcionais, livres ou voluntárias. É preciso assim procurar extensividades em pontos específicos do texto, como quando o regimento determina que a "estrutura dos CEUs privilegiará as relações horizontais". ${ }^{30}$ Isso remete à noção de autonomia das partes e à possibilidade de relações voluntárias entre elas, de uma forma que o âmbito espacial está menos apto a especificar. Ao lado disso, relações verticais produzem hierarquias de poder que certamente estão mais próximas da ideia de interações obrigatórias, não voluntárias ou não opcionais - sobretudo para o lado da relação dotado de menos poder. Desse modo, no âmbito jurídico as relações de igualdade estão mais diretamente mescladas à livre escolha por interagir e à extensividade, enquanto as relações hierárquicas aparecem mais diretamente vinculadas à impossibilidade de escolher as interações - em outras palavras, a liberdade e a igualdade estão mais diretamente relacionadas no âmbito jurídico do que no âmbito do espaço.

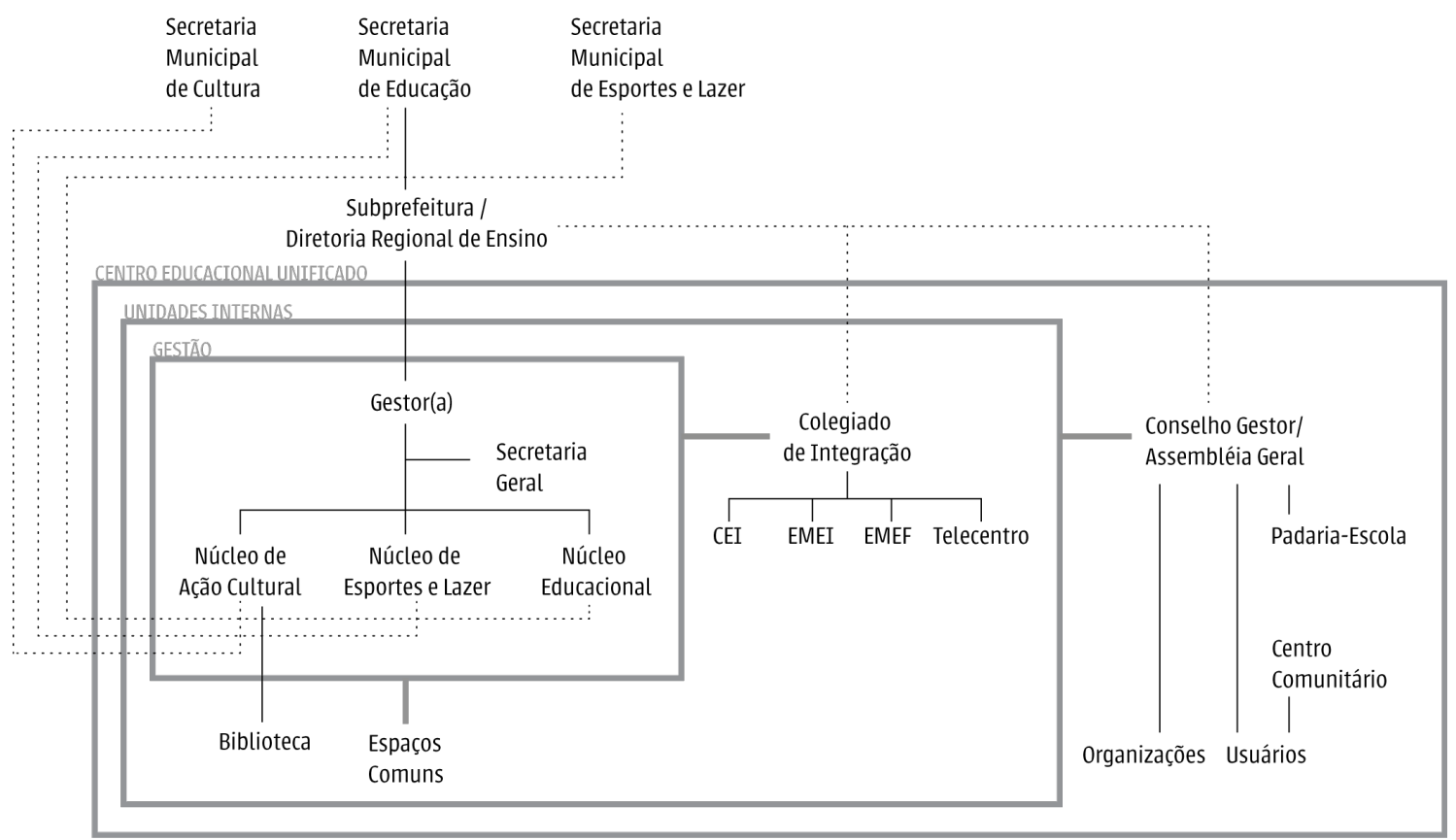

Figura 12 - Organograma dos CEUs na gestão Marta Suplicy (2001-2004).

\footnotetext{
${ }^{30}$ Conforme o Artigo $9^{\circ}$ do $1^{\circ}$ Regimento dos CEUs. Isso é parte de um esforço mais amplo do governo Suplicy para descentralizar o governo municipal, interessado em delegar poderes, recursos e autonomia à instância regional. Esse conjunto de medidas buscou minimizar entraves de atendimento a demandas locais, equalizar a distribuição de recursos pelas regiões da cidade e permitir a participação do cidadão nos processos decisórios do governo. Assim, a gestão Suplicy criou 31 Subprefeituras para substituir as 28 Administrações Regionais precedentes, mas também para reorganizar outras instâncias de poder regional e fazer coincidir seus limites, incluindo-se aí 41 Distritos de Saúde, 17 Supervisões de Assistência Social e 13 Núcleos de Ação Educativa. As escolas e CEUs passaram a ser supervisionados por uma coordenadoria de educação vinculada às subprefeituras (SUPLICY, 2008).
} 
Para facilitar nossa análise, o organograma acima foi elaborado com base no regimento interno mencionado. ${ }^{31}$ De um modo geral, ele mostra que os CEUs de fato possuem uma quantidade reduzida de entidades relacionadas verticalmente, e um grande número de vínculos horizontais que indicam a presença de extensividades de âmbito jurídico.

Podemos encontrar extensividades na constituição da gestão, representada pelo retângulo menor do organograma. A gestão é responsável pela articulação dos equipamentos internos do CEU, pela promoção de cursos e atividades, e pela administração dos espaços comuns. O gestor ocupa o cargo de maior hierarquia dentro do CEU, mas, como o regimento determina que ele seja eleito por usuários e funcionários, essa relação de assimetria é amenizada por uma margem de escolha voluntária que se aproxima da ideia de extensividade. O gestor é assessorado por três núcleos - Educacional, de Ação Cultural e de Esportes e Lazer - que não estão subordinados uns aos outros. Eles se vinculam primeiramente ao gestor e, secundária e respectivamente, às secretarias municipais de Educação, de Cultura e de Esporte, Lazer e Recreação, como mostra o texto da lei: "O Núcleo de Ação Cultural do CEU é a unidade que se reporta ao Gestor, ouvidas as orientações técnicas da Secretaria Municipal de Cultura". ${ }^{32}$ Esses vínculos secundários, representados em pontilhado no organograma, não são imprescindíveis para a condução do cotidiano do CEU, e nesse sentido dependem mais da vontade das partes em travar interação - o que introduz mais uma parcela de extensividade à gestão.

Os demais equipamentos que compõem o CEU, por sua vez, não estão diretamente subordinados à gestão, mas se articulam a ela no grupo de trabalho denominado Colegiado de Integração, conforme vemos no retângulo intermediário do organograma. A extensividade representada por esses vínculos horizontais amplia-se com a constituição de outros vínculos não imprescindíveis (em pontilhado) entre o colegiado e instâncias superiores de governo. Finalmente, o organograma realiza uma última expansão lateral para articular, no Conselho Gestor, representantes eleitos dos diversos equipamentos do centro educacional, instâncias superiores de governo, usuários e organizações do entorno urbano. O regimento atribui funções consultivas e deliberativas ao Conselho Gestor, de modo que ele estabelece vínculos horizontais com os outros equipamentos do CEU. Esses vínculos e a definição de representantes eleitos em regime de

\footnotetext{
${ }^{31} \mathrm{O}$ organograma indica uma quantidade de vínculos maior do que a que teremos espaço para analisar.

${ }^{32} 1^{\circ}$ Reg. Art. 14.
} 
trabalho voluntário trazem mais componentes extensivos ao $\mathrm{CEU}$, fazendo com que a gestão dependa em grande medida do interesse das pessoas em travar relações.

Uma segunda transposição da noção de extensividade ajuda a ampliar nosso entendimento a respeito das intenções de nossos sujeitos de pesquisa, na medida em que eles procuraram relacionar os dispositivos espaciais e legais supracitados a concepções pedagógicas desenvolvidas pelo educador Paulo Freire. ${ }^{33}$ Concepções e projetos pedagógicos podem ser entendidos como contextos, na medida em que instituem regras e diretrizes de ação capazes de condicionar as dinâmicas interacionais cotidianas, particularmente entre professores e alunos. A pedagogia da libertação freiriana constrói-se em oposição à predominância do que Paulo Freire chama de educação opressora, que considera o aluno como um depósito passivo de conhecimentos transmitidos de cima para baixo pelo professor (FREIRE, 1968). Além disso, o educador considera que esse tipo de educação distingue alunos em termos de merecimento, suscitando uma lógica de competição que os prepara para uma inserção no sistema capitalista e os distancia de uma visão crítica e solidária da sociedade. Nesse sentido, Freire propõe uma educação que parta dos interesses do aluno, fazendo-se numa parceria voluntária entre ele e o professor, ambos entendidos como integrantes do processo de aprendizado (FREIRE, 1968).

Vemos mais uma vez uma oposição dicotômica entre um termo considerado desejável e outro termo considerado indesejável, com correspondências entre os projetos arquitetônicos e políticos, e mesmo com as ideias que poderiam ter inspirado um projeto pedagógico: procuram-se implantar espaços abertos, vínculos horizontais e práticas pedagógicas libertárias, enquanto constroem-se oposições a fechamentos de espaço, vínculos hierárquicos e práticas pedagógicas opressoras. A preocupação com a liberdade de ação e interação atravessa todos esses termos, sendo vista como um fator central para o favorecimento dos moradores do entorno urbano dos CEUs - e, portanto, para a promoção do acolhimento. Mas será que a extensividade relaciona-se deste modo tão exclusivo e direto com o acolhimento?

Já observamos que os espaços abertos não estão necessariamente relacionados a um

\footnotetext{
${ }^{33}$ Essas relações são constamente lembradas por políticos e arquitetos. A título de exemplo, podemos citar este excerto em Doria (2007): “A concepção pedagógica da atual gestão leva muito em conta as ideias e propostas da escola aberta e democrática que o educador Paulo Freire procurou pôr em prática, em 1989, quando foi secretário da Educação no município de São Paulo. Segundo seu ideário, um governo democrático que quisesse incentivar a participação popular e promover a cidadania deveria investir na educação de qualidade e desenvolver espaços para a formação integral de cidadãos e cidadãs, espaços de convivência comunitária, combinando várias estratégias para desenvolvimento da consciência crítica em todas as idades. [parág.] Entre as estratégias, incluem-se o acesso a espaços públicos de convivência [...] A escola pode e deve propiciar acesso a tudo isso, não só para os seus alunos, mas para toda a comunidade local".
} 
conjunto de efeitos desejáveis. Ao contrário do que muitos afirmam, espaços abertos não produzem, por si sós, convívio harmonioso ou relações de igualdade - foi assim que associamos a extensividade a uma propriedade precisa, relativa à livre escolha de ações e interações. No entanto, vamos observar agora que mesmo esta qualidade específica não está exclusivamente relacionada a efeitos positivos: há ainda um descompasso entre o que se pensa que a livre interação produz e o que ela efetivamente produz. Isso acontece porque a livre interação engendra um leque maior de consequências para as interações cotidianas, e dentro desse leque podemos encontrar tanto efeitos desejáveis quanto indesejáveis. Para investigar esses nexos, fica claro que não podemos trabalhar em uma chave binária que opera por opções dicotômicas e mutuamente excludentes.

Nos próximos tópicos, vamos apontar para dois conjuntos de efeitos indesejáveis da extensividade, cada um deles relacionado à construção de outro tipo de contexto, também portador de um leque ambíguo e variado de consequências. Ao final do exercício, contaremos com um desenho de três tipos de contexto que empregaremos na análise etnográfica do cotidiano dos CEUs Butantã e Vila Rubi. Desenho, vale lembrar, que surgiu da própria experiência etnográfica, ainda que ela não figure nas considerações deste capítulo.

\subsection{Separações}

Propomos agora um segundo tipo de contexto das interações cotidianas, que denominamos contexto separador. Vamos apontar para a centralidade que esse tipo de contexto ocupou na criação tanto do segundo projeto de arquitetura quanto do segundo regimento interno dos CEUs desenvolvidos e adotados pelas gestões de José Serra (2005-2006) e Gilberto Kassab (2006-2012). O segundo projeto arquitetônico foi utilizado na construção de mais 24 centros educacionais, que passaram a contar com espaços muito diferentes dos que vimos no tópico anterior. $\mathrm{O}$ segundo regimento, por sua vez, passou a presidir o funcionamento de todos os 45 CEUs da cidade, estando em vigência até o presente momento, ainda que a atual gestão, de Fernando Haddad, tenha sinalizado sua substituição. Após observarmos a força das separações nesses dispositivos legais e espaciais, veremos como ela também está presente em outros lugares. Finalmente, a ideia é 
assinalar que as separações estão envolvidas na produção de uma gama de efeitos nas interações cotidianas, os quais não são necessariamente contrários à promoção do acolhimento.

Os terrenos destinados à construção dos CEUs durante as gestões de José Serra e Gilberto Kassab já haviam sido desapropriados durante a gestão de Marta Suplicy, de acordo com o raciocínio urbanístico desenvolvido em parceria com os arquitetos de Edif, como já assinalamos. Se a produção dos projetos dos primeiros CEUs contou com um esquema descentralizado, em que cada unidade foi implantada por um escritório privado diferente, o segundo projeto não contou com a participação do Edif, concentrando-se inteiramente num único escritório da iniciativa privada, pertencente ao arquiteto Walter Makhohl (CORBIOLI, 2008) ${ }^{34}$. Um ponto em comum às duas propostas reside na definição de técnicas construtivas padronizadas para diminuir custos e tempos de construção, ainda que, no segundo projeto, o sistema construtivo tenha adotado vãos e peças de menor envergadura.

O entendimento dos CEUs como centralidades urbanas ou como locais de articulação entre equipamentos públicos e moradores de regiões periféricas não parece ter inspirado decisões de projeto na escala do edifício, diferentemente do que observamos na versão anterior. Se a definição de espaços abertos ao livre trânsito dos usuários serviu como mote inspirador da primeira proposta, a segunda foi encomendada com a exigência de "evitar a circulação do público nos blocos das salas de aula" (CORBIOLI, 2008, p. 56). Fica evidente, assim, a intenção de contraponto em relação às propostas originalmente desenvolvidas pelo Edif. Mas, cabe assinalar, a proliferação de separações e segmentações do projeto certamente não são motivadas apenas pela intenção de contraponto, guiando-se por seus próprios valores e intenções.

Em primeiro lugar, dois volumes destinados a abrigar as unidades educacionais - um deles inteiramente destinado à EMEF, o outro abrigando CEI no térreo e EMEI no primeiro andar seguiram a solução convencional de um corredor de circulação no interior da planta, dando acesso a salas de aula em ambas as laterais, como podemos ver na imagem seguinte:

\footnotetext{
${ }^{34}$ A Makhohl Arquitetura chegou a contar com cerca de cem arquitetos trabalhando no detalhamento dos projetos.
} 

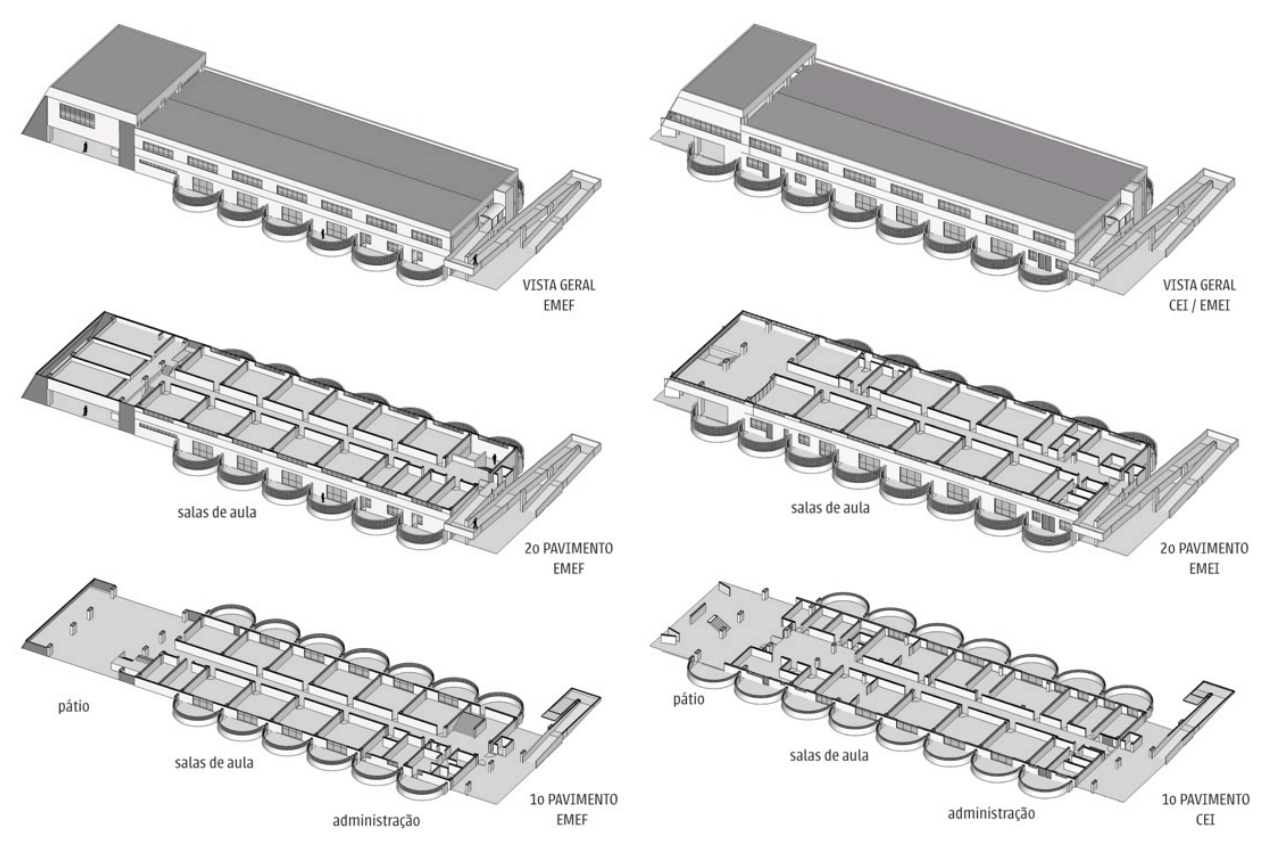

Figura 13 - Perspectiva das escolas - conforme o segundo projeto arquitetônico dos CEUs.

A rotina de deslocamentos no interior da escola torna-se assim mais introspectiva do que aquela observada no primeiro projeto dos CEUs. Além disso, os pátios das escolas encontram-se no final dos corredores de circulação, de modo que, enquanto os edifícios orientam suas entradas aos espaços livres comuns do centro educacional, os pátios tendem a ficar no outro extremo, isolados. Contribui para esse isolamento o fechamento de uma das laterais dos pátios com o emprego de lajes pré-fabricadas. 


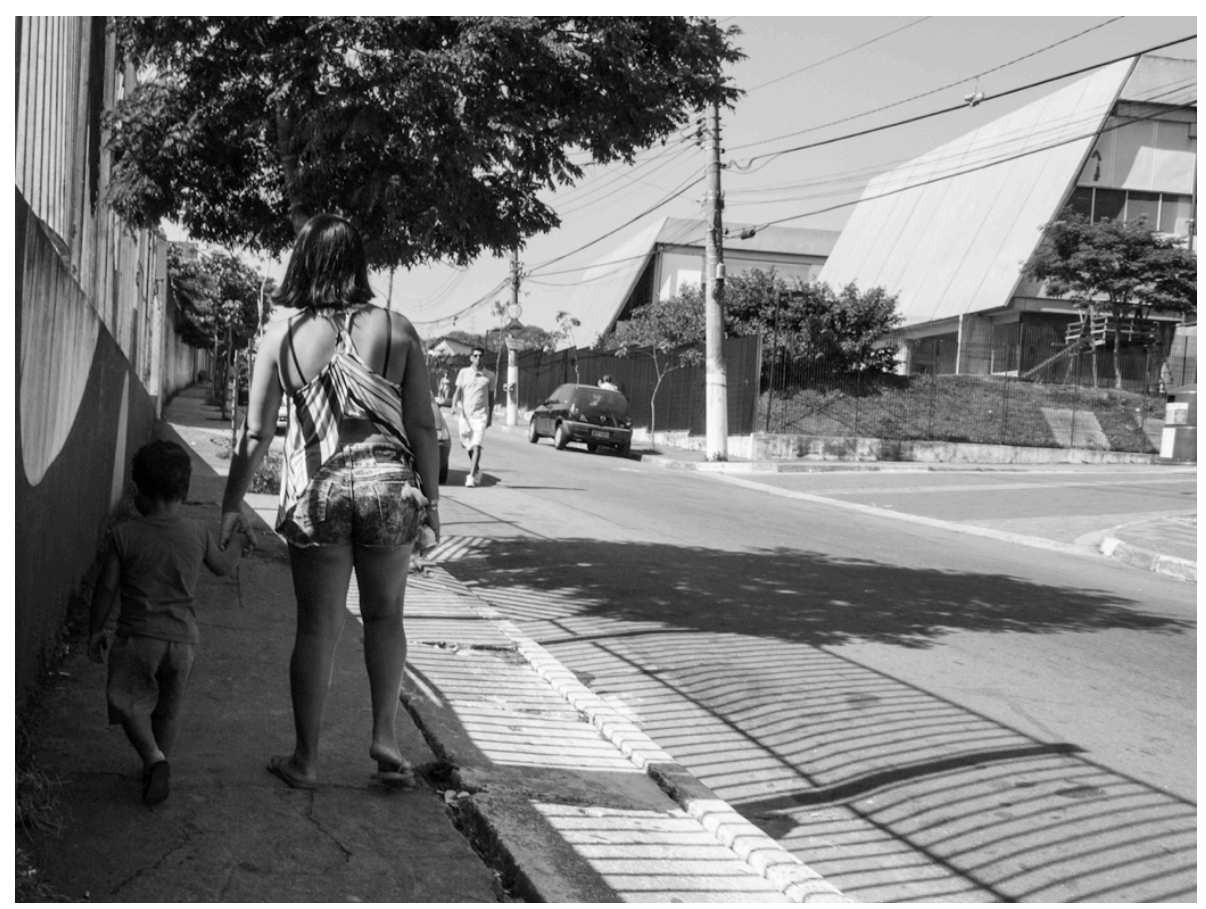

Figura 14 - Vista exterior do CEU Vila Rubi, com fechamentos laterais em lajes pré-fabricadas.

Outros fechamentos podem ser observados. A disposição em corredor central daria oportunidade às salas de aula de estabelecerem relações visuais com os espaços exteriores - mas isso também foi descartado pelo projeto, que procurou "evitar a depredação das vidraças" (CORBIOLI, id., p. 62) envolvendo-as numa sequência de paredes em semicírculo com elementos vazados que obstruem a visão entre interior e exterior. Posteriormente, os espaços entre essas paredes de elemento vazado e as janelas receberam a proposta de abrigar atividades ao ar livre, e desse modo cada sala de aula passou a contar com seu próprio espaço externo, exíguo e isolado dos outros.

Os fechamentos são assim utilizados para separar espaços externos e internos da escola, separando também espaços entre salas de aula. Fica claro, ainda, que a solução de elementos vazados em semicírculo procura ser explorada como recurso expressivo da solução arquitetônica final. 


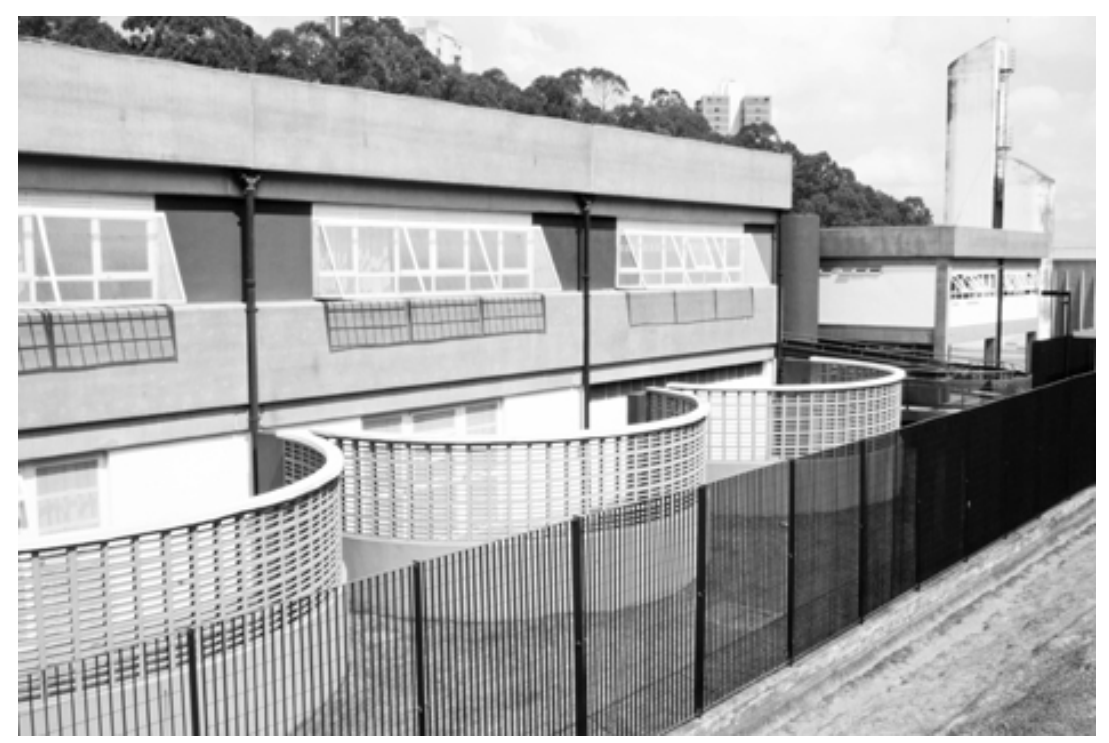

Figura 15 - Vista exterior do CEU Paraisópolis, com grades e espaços intersticiais.

A fotografia mostra ainda uma característica marcante dos espaços exteriores configurados pelo segundo projeto: a presença de uma grande quantidade de recuos entre edifícios e divisas de lote que não receberam previsão de utilização. Esses espaços intersticiais foram ampliados pela decisão de agrupar os demais equipamentos do CEU em uma quantidade maior de pequenos volumes edificados, que demandam afastamentos recíprocos dentro do próprio lote. Dessa forma, reduziram-se as possibilidades de configurar áreas livres mais amplas, efetivamente capazes de abrigar atividades. Temos agora mais três volumes construídos, além daqueles destinados às unidades educacionais, e neles a presença dos fechamentos é menos expressiva. $\mathrm{O}$ menor abriga os escritórios da gestão (no primeiro andar), enquanto prevê uma área coberta no térreo que, no caso do CEU Vila Rubi, é de difícil ocupação porque abriga uma rampa de circulação: 


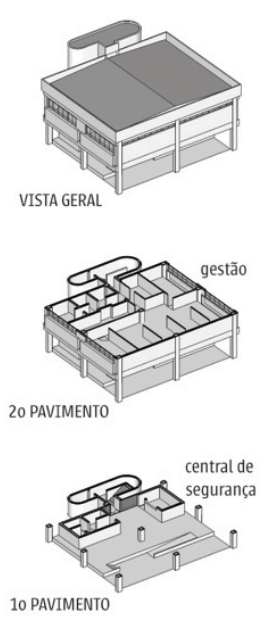

Figura 16 - Perspectiva da gestão - conforme o segundo projeto arquitetônico dos CEUs.

Outro edifício possui uma planta circular que alude ao formato do bloco do CEI do primeiro projeto arquitetônico. Mas, neste caso, temos um refeitório aberto aos espaços internos do CEU equipamento que ganha destaque nas interações cotidianas do CEU Vila Rubi e que não existia no primeiro projeto dos CEUs - e, no primeiro andar, a biblioteca e o telecentro:

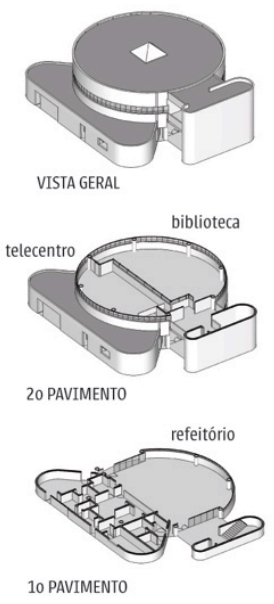

Figura 17 - Perspectiva da biblioteca, do telecentro e do refeitório - conforme o segundo projeto arquitetônico dos CEUs.

Finalmente, um último volume recebe um teatro e um ginásio, além de salas para cursos diversos. Neste bloco, as lajes pré-fabricadas foram aproveitadas para configurar empenas cegas, destinadas a receber obras de artistas plásticos que não chegaram a ser realizadas. 

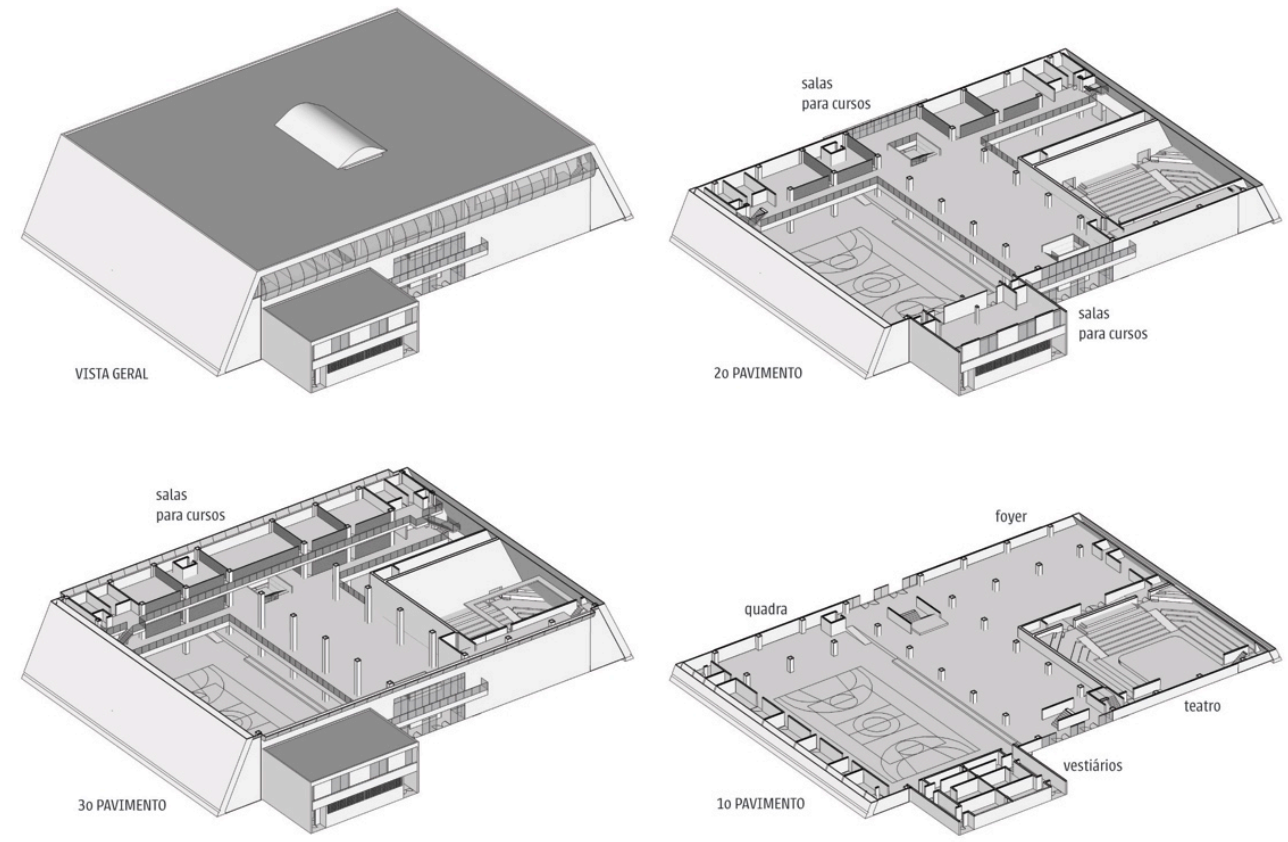

Figura 18 - Perspectiva do bloco esportivo e cultural - conforme o segundo projeto arquitetônico dos CEUs.

Essa caracterização mostra que o segundo projeto admitiu com mais veemência a intenção de isolar as pessoas e as atividades desenvolvidas em cada espaço, e isso ocorreu principalmente nos edifícios escolares. Ainda que as interações entre alunos e professores possam acontecer no corredor interno de circulação das escolas, as salas de aula fechadas, com seus próprios quintais isolados, estão vedadas ao contato com o corredor e com o exterior da escola, enquanto os pátios encontram-se igualmente isolados dos espaços comuns do CEU.

Embora os outros edifícios desse segundo projeto dos CEUs não revelem uma intenção tão explícita de separar pessoas, o contraste com o primeiro projeto se mantém, já que a abertura espacial certamente não funcionou como uma inspiração importante da poética de arquitetura. Tal contraste deixa claro que estamos diante de outro tipo de contexto, dotado de expectativas diferentes com relação aos efeitos que pode produzir nas dinâmicas interacionais cotidianas: assim como acontece em grande parte das escolas municipais, trata-se aqui de empregar recursos como paredes, portões e trancas para efetivar separações e controles. Esses recursos não só limitam a possibilidade de as pessoas optarem pelas interações, como acarretam ainda uma eventual diminuição de encontros e desaceleração das dinâmicas interacionais.

O mesmo tipo de contexto reaparece no âmbito político, orientando a substituição do 
primeiro regimento por um segundo, promulgado em 05/12/2006. O novo regimento manteve a estrutura básica de entidades apresentada no organograma do tópico anterior, mas produziu uma redistribuição de poder que fortaleceu as relações hierárquicas e diminuiu o peso das relações horizontais. Além disso, separou os diversos envolvidos ao definir atribuições e responsabilidades mais exclusivas a cada um deles (SÃO PAULO, 2006). Em primeiro lugar, o gestor, possuidor do cargo mais alto na hierarquia dentro do CEU, deixa de ser eleito por funcionários e usuários, passando a ser nomeado por ato do executivo municipal, para exercer a função por prazo indeterminado. ${ }^{35}$ Com isso, retira-se o sentido de escolha trazido pelo exercício do voto, reforçando a natureza assimétrica dos vínculos.

Ao analisar o primeiro regimento, verificamos que os três núcleos da gestão subordinavamse ao gestor, e secundariamente às suas respectivas secretarias de governo. Porém, representamos este último tipo de subordinação com linhas pontilhadas, para indicar que, na administração cotidiana dos CEUs, ele não era tão imprescindível quanto os outros e, não o sendo, dependia mais do interesse das pessoas para se efetivar. O segundo regimento elimina esse tipo de vínculo mais voluntário, determinando responsabilidades estanques e bem delimitadas para cada um dos envolvidos, de modo que os vínculos restantes são justamente os de natureza hierárquica entre gestor e núcleos. Além disso, os cargos dos núcleos de Ação Cultural e de Esportes e Lazer deixam de ser preenchidos por suas respectivas secretarias; eles passam a ser ocupados por educadores lotados na Secretaria Municipal de Educação. Enfim, a Secretaria Municipal de Cultura e a Secretaria Municipal de Esportes, Lazer e Recreação deixam de marcar presença nos CEUs, tanto pela destituição de atribuições específicas quanto pela retirada de seu poder de nomeação.

Partem daí muitas das críticas ao modo como os CEUs passaram a ser geridos a partir de então. A implementação dos três núcleos teve em vista não apenas uma compreensão de educação que abarcava também as atividades culturais e esportivas não escolares,${ }^{36}$ como também procurava

\footnotetext{
${ }^{35}$ Vale uma comparação do texto dos dois regimentos quanto a este aspecto: $1^{\circ}$ Regimento, art. $55^{\circ}$, parág. $1^{\circ}$ : "O Gestor será eleito, para mandato de 2 (dois) anos, em lista tríplice elaborada em Assembleia Geral do CEU, cujo processo eleitoral será coordenado pela Coordenadoria de Educação da Subprefeitura, de acordo com as orientações legais e da SME"; $2^{\circ}$ Regimento, art. 13: "O Gestor do CEU será nomeado por ato do Executivo Municipal, conforme proposta do secretário de Educação, de acordo com as orientações legais e diretrizes oficiais".

${ }^{36}$ Nas palavras de Marta Suplicy: "Lidávamos com um conceito de educação mais abrangente do que a questão estritamente pedagógica [...]. Para colocar em prática essa concepção, era preciso adotar a gestão quadripartite das unidades dos CEUs, envolvendo a Secretaria de Educação, a de Cultura, a de Esportes e a comunidade" (SUPLICY, 2008, p. 145).
} 
implementá-las dentro de uma perspectiva intersecretarial, capaz de reunir, numa mesma mesa de trabalho, servidores com trajetórias, valores e preocupações diferentes. O segundo regimento concebeu uma gestão composta apenas por educadores, e em minhas visitas de campo pude encontrar diversos artistas e produtores culturais que apontavam para o despreparo daqueles profissionais em definir, por exemplo, uma programação cultural. Além disso, indica-se agora frequentemente uma dificuldade generalizada dos educadores em construir e alimentar intercâmbios com pessoas, entidades e organizações externas aos CEUs, como mostram alguns depoimentos colhidos em 2008 em centros educacionais de São Miguel: "[...] quando eram três secretarias, o CEU era mais voltado para fora, mas agora é mais voltado para dentro. [...] O pessoal da educação não tem a cultura de se abrir para outras propostas" (GROSBAUM; CARVALHO, 2008, p. 14).

Enfim, tanto as separações administrativas quanto as separações de espaços que observamos anteriormente são semelhantes ao que geralmente é dito do cotidiano das escolas públicas em geral. Nesse sentido, as mudanças trazidas pela gestão de José Serra podem ser vistas como produtoras de uma inversão na vocação dos CEUs, que deixam de ser centralidades urbanas abertas para se tornarem grandes escolas fechadas - ou "escolões", na expressão cunhada em algumas análises correntes. ${ }^{37}$ Vale acrescentar que o tamanho dos espaços dedicados a atividades culturais e esportivas foi bastante reduzido no segundo projeto arquitetônico dos CEUs, denotando uma maior preocupação com os espaços escolares. ${ }^{38}$ É possível observar, assim, que a discussão sobre separações ativa uma oposição entre CEUs e universo escolar, indicando incompatibilidades importantes entre os dois. Se existem contradições entre o projeto original dos CEUs e os valores e práticas dominantes no campo da educação, elas são pouco abordadas pelos discursos que defendem o cunho fundamentalmente educacional dos CEUs, comuns tanto em documentos oficiais quanto entre os servidores que atuam no cotidiano dos CEUs. Retornaremos a este ponto no próximo capítulo.

Voltando à análise do segundo regimento, podemos dizer que os vínculos horizontais entre

\footnotetext{
${ }^{37} \mathrm{O}$ arquiteto Alexandre Delijaicov critica o termo "escolão" nas entrevistas concedidas a mim em outubro de 2010 , vinculando a origem da expressão tanto a certas notícias da grande mídia quando a políticos que assumiram a Prefeitura depois da gestão de Marta Suplicy. Em seu ponto de vista, o termo "escolão" demonstra uma incompreensão do projeto dos CEUs, podendo adquirir um tom pejorativo e análogo à expressão "cadeião".

${ }^{38}$ É Souza quem procura realizar essa comparação de forma mais sistemática (SOUZA, 2010, p. 57-62). As diferenças mais significativas estão nos tamanhos dos teatros (a capacidade de 450 lugares do primeiro projeto reduz-se para 180 no segundo) e das bibliotecas (no primeiro projeto, a área das bibliotecas gira em torno de 500 metros quadrados; no segundo, cai para cerca de 100 metros quadrados).
} 
gestão e outras entidades tiveram sua força atenuada, ao lado da eliminação de outros vínculos não imprescindíveis, o que terminou por conferir uma presença mais expressiva às relações assimétricas. O Colegiado de Integração deixa de ser qualificado como "braço direito das políticas públicas definidas nas instâncias superiores", perde várias atribuições e passa da frequência quinzenal para a mensal. ${ }^{39} \mathrm{O}$ Conselho Gestor passa a reunir uma quantidade menor de membros, que não eram mais eleitos, deixa de contar com representantes de instâncias superiores de governo e tem a frequência das reuniões reduzida de mensal para bimestral. O Conselho deixa de ser uma instância consultiva e deliberativa, e passa a contar apenas com a função consultiva, perdendo o poder de opinar sobre convênios e contratos, e de decidir sobre a aplicação de recursos em ações e projetos. $^{40}$

No cenário mais amplo da gestão municipal, o mandato de José Serra (2005-2006) representa uma volta à centralização do poder nas secretarias de governo, retirando atribuições, recursos e funcionários das subprefeituras criadas na gestão Marta Suplicy. Serra também restitui a divisão administrativa da educação em 13 regiões, que passam a se chamar Diretorias Regionais de Ensino (DREs), desvinculando-a das subprefeituras. Parte dos motivos relacionados à volta da centralização parece residir em certos problemas trazidos pela descentralização, e é para a análise destes problemas que pretendemos nos voltar agora.

As dificuldades relacionadas à entrega de poder e autonomia são reconhecidas pela própria Marta Suplicy (2008), que fala de um aumento significativo de custos com contratação de funcionários, da falta de pessoal qualificado para assumir cargos regionais nas subprefeituras, do avanço de sectarismos locais relacionados à influência de vereadores ${ }^{41}$ e das dificuldades de organização e administração em geral.

Outro depoimento ilustrativo desses problemas é realizado por José Aristodemo Pinotti em 2005, quando passa a integrar a recém-empossada gestão de José Serra (2005-2006) como secretário de Educação. Em dois comunicados oficiais (PINOTTI, 2005a, 2005b), o então

\footnotetext{
${ }^{39}$ Conforme artigos 46 a 51 do $1^{\circ}$ Reg, e 26 a 30 do $2^{\circ}$ Reg.

${ }^{40}$ Conforme as fontes: $1^{\circ}$ Regimento, arts. $24,38,39,45 ; 2^{\circ}$ Regimento, arts. 22,25 e 44 . A Assembleia Geral, instância de participação direta de reunião anual, deixou de existir. No entanto, o segundo regimento criou a Associação de Pais, Mestres, Servidores, Usuários e Amigos do Centro Educacional Unificado (APMSUAC), vinculando seu funcionamento à "legislação vigente", sem maiores esclarecimentos de função, periodicidade ou composição.

${ }^{41}$ Frequentemente aponta-se (como em Ottman, 2005, apud Pacheco, 2009, p. 46-9) para uma contradição entre discursos e práticas, entre a iniciativa de delegar poder aos cidadãos e a disposição do governo Marta Suplicy em negociar cargos administrativos com forças políticas e interesses duvidosos que, afirma-se, terminaram por prevalecer, comprometendo os objetivos almejados.
} 
secretário procura marcar uma diferença em relação ao estilo de gestão anterior, dizendo ter encontrado um "caos administrativo" na Secretaria de Educação. Seu relatório menciona que praticamente todos os recursos da secretaria eram executados pelas subprefeituras, e que não havia uma "política de educação". Inúmeros professores haviam sido deslocados para os cargos das subprefeituras, de modo que faltavam profissionais nas escolas. A secretaria estava caracterizada como "terra de ninguém", com inúmeras ONGs trabalhando sem definição de um projeto educacional conjunto. Enfim, Pinotti aponta que, além de a Secretaria de Educação estar com dívidas acumuladas nos meses anteriores, não havia conseguido substituir a grande maioria das 54 "escolas de lata", construídas com materiais precários para atender demandas emergenciais durante a gestão de Celso Pitta (1997-2000).

Nessa toada, Pinotti defende a implantação de um "gerenciamento estratégico eficiente, que permita corrigir defeitos graves e implementar projetos, tirando-os do papel, fazendo com que as modernas e eficientes práticas pedagógicas possam chegar à rotina das escolas" (PINOTTI, 2005a, p. 10, grifos nossos). Multiplicam-se, em sua fala, palavras de ordem como "avaliação", "organização", "programação", "aprimoramento", "eficiência", "correção", "planejamento estratégico", entre outras, numa argumentação que contrasta claramente com a da gestão petista. Nota-se no discurso de Pinotti um tom mais econômico em referenciais teóricos e acadêmicos (mesmo as "modernas e eficientes práticas pedagógicas" acima referidas não chegam a ser nomeadas), e mais rico em tabelas e indicadores estatísticos. O comunicado não relaciona a implementação da "eficiência administrativa" à volta da centralização do poder municipal - antes, defende uma descentralização à sua maneira, transferindo recursos para as Associações de Pais e Mestres nas unidades educacionais, dentre outras medidas muito mais tímidas do que as que vimos anteriormente.

É de esperar que depoimentos de cunho político, como os de Suplicy e Pinotti, tragam para o primeiro plano as ações e preocupações passíveis de serem vistas como positivas, deixando de enfatizar implicações e consequências controversas. Assim, se uma gestão propõe descentralizar recursos e poderes, a outra não marcará sua posição com a menção à retirada e concentração de poder, mas com a defesa de outro valor positivo: a eficiência administrativa. ${ }^{42}$

\footnotetext{
${ }^{42}$ Moacyr Gadotti (2004, p. 9-10), educador que participou do esforço de implementação dos CEUs, oferece pistas sobre o modo como partidários do acolhimento, na gestão Marta Suplicy, viam práticas semelhantes às de Pinotti. Para ele, a criação dos CEUs pretendia se opor à "tradição autoritária do sistema educacional brasileiro", que tende a tratar a educação como "execução de objetivos político-ideológicos" a serviço de um "aparelho de Estado"
} 
Mas os depoimentos não tratam simplesmente de uma oposição entre valores, porque um é entendido como o reverso do outro. Não parece exagerado afirmar que quanto maior a descentralização e o poder de escolha conferido, maior a possibilidade de variação das ações portanto, maior a imprevisibilidade e a incerteza. De modo inverso, quanto maior a centralização do poder, menor a margem de ação das pessoas, maior a sua previsibilidade e controle, e maior a segurança e a eficiência. Em poucas palavras, podemos falar de uma dicotomia entre os valores mutuamente excludentes da liberdade e da previsibilidade. Implicitamente, estão também em jogo os pontos negativos desses valores positivos: há uma coincidência entre previsibilidade e centralização de poder; e outra coincidência entre incerteza e liberdade.

Consideramos anteriormente como as dicotomias - entre periferia e CEU, entre teatros de rico e de pobre - foram mobilizadas por Marta Suplicy para justificar decisões importantes de governo. Agora, temos mais uma mostra do poder dessas essencializações, entendidas como atribuições de essência, capazes de fazer "coisas com palavras" (HERZFELD, 2008, p. 49, 51, 261): políticos interessados em demarcar diferenças recíprocas atribuem identidades a si e aos outros, e passam a orientar suas ações por essas demarcações.

No entanto, há outras dinâmicas que não operam com essas regras; ao observá-las, deslocamos o debate em direção a outros nexos. Uma delas alinha-se ao ideário freiriano e procura entender a incerteza - e a insegurança trazida com atitudes de usuários dos CEUs - como etapa momentânea de um processo político que leva, em última instância, a uma situação em que a liberdade não é incompatível com os outros valores supramencionados. De acordo com essas ideias, isso só poderia acontecer quando a liberdade é assumida como uma constante em todo o processo: de acordo com a fala atribuída a Paulo Freire pelo educador Marcos Coutinho, "para educar para a liberdade é preciso educar na liberdade". ${ }^{43}$ A educadora Anna Cecília Simões, exgestora do CEU Butantã, considera que a tarefa de um educador é justamente construir este processo de diálogo e aprendizado, e que, ao impor regras não consensuadas, se está justamente

disseminador "dos códigos, símbolos e valores dos grupos que dominam o poder", relegando a um segundo plano os interesses e necessidades da comunidade local. Para Gadotti, esse estilo de gestão organiza-se de acordo com um modelo "empresarial-piramidal", que centraliza o poder e separa as instâncias de decisão das de execução, distribuindo cargos de acordo com a lógica da lealdade política e à revelia da competência administrativa. Analogamente, no entender de Gadotti, os objetivos pedagógicos subordinam-se aos administrativos. Enfim, esta análise fecha o círculo de citações recíprocas e termina o esboço de mapeamento de tensionamentos políticos aqui apresentados.

${ }^{43}$ Marcos Coutinho é professor da EMEF do CEU Vila Rubi, e mencionou a frase de Paulo Freire numa reunião de Conselho Gestor em 25/04/2013. 
abdicando da educação. No limite, esse raciocínio indica que as separações, entendidas como dispositivos empregados para produzir efeitos não voluntários, não deveriam ser utilizadas. ${ }^{44}$

Outra dinâmica aparece no relato de Marta Suplicy sobre certas questões decorrentes da descentralização e com a definição da programação cultural dos CEUs:

Houve algumas experiências desastrosas, mas pedagógicas. Um belo dia, sem aviso, fui assistir a uma representação. Diante de uma plateia cheia, vi, horrorizada, um elenco de pequenas "paquitas" se contorcer numa duvidosa coreografia. Fiquei de cabelo em pé. Perguntei à diretora como aquilo tinha ido parar num palco do CEU e ela, muito simplesmente, explicou: "Temos a orientação de apresentar 50\% da programação com indicações da programação da Secretaria da Cultura e os outros $50 \%$ de produção da comunidade. Estamos com mais de cem grupos locais inscritos. Não temos como assistir e selecionar; é por ordem de inscrição". Nesse dia mandei contratar um produtor cultural para cada CEU. [...] Nunca mais assistimos a espetáculos de quinta categoria nos CEUs. Foi saudável introduzir os repertórios da cultura e do esporte no cotidiano da escola, mas aprendi que esse convívio não acontece espontaneamente e requer, além de muita negociação, alguma firmeza. (SUPLICY, 2008, p. 146)

A "firmeza" motivou a contratação de produtores culturais, ou seja, a concentração relativa de poder apto a fazer frente a dificuldades de certa forma semelhantes àquelas implícitas nos depoimentos acima, sob os termos "risco de não controlar", "caos administrativo", "terra de ninguém" ou "experiências desastrosas". No que se refere ao emprego de assimetrias de poder, a expressão "alguma firmeza" de Suplicy sugere ainda que a diferença em relação à posição de Pinotti se faz em termos de grau, ainda que em outros aspectos esses políticos pareçam sustentar posições tão diferentes. Para Marta Suplicy, a limitação de algumas liberdades não só não se opõe à promoção do acolhimento, como faz parte de sua viabilização. ${ }^{45}$ Esta hipótese se opõe à

\footnotetext{
${ }^{44}$ Presenciei uma discussão exemplar nesse sentido, durante uma "roda de formação" promovida pela educadora Anna Cecília Simões (ex-gestora do CEU Butantã) no CEU Paz, em 27/11/2013. Funcionários da instituição queixavam-se de dificuldades para garantir a segurança: "teve uns meninos aqui no começo [...], eles vivia assim: quando a gente pegava ele dando aquele mortal nas porta, dando uma tesoura aí em alguma coisa ou tentando pichar alguma coisa, eu dizia assim, 'não faça isso, está errado'" O relato foi seguido da observação de um outro funcionário, que considerou que uma conduta respeitosa "não entra na cabeça deles." Anna Cecília imediatamente respondeu: "Entra! Entra se a gente acreditar! Processo de educação, processo de educação é movimento, é processo, que é construção". A educadora defendeu com conviç̧ão a realização de "rodas de conversa" com os jovens, como alternativa à convocação da polícia e à imposição de regras e normas.

${ }^{45}$ A mesma ideia de gradação no emprego das separações aparece no relato de uma ex-gestora a Pacheco (2009): "Na abertura do CEU para a comunidade, como eu tenho esse perfil gerencial, eu planejei essa abertura, porque se você não abre com algumas regras básicas a gente tem problemas, nós estamos numa comunidade de periferia, que nunca teve acesso a esse tipo de equipamento, se você abre sem regra, sem negociação, sem controle, íamos ter problemas" (PACHECO, 2009, p. 134).
} 
valorização exclusiva do diálogo e do convencimento que observamos entre os educadores mais fiéis ao ideário freiriano, anteriormente mencionados; também parece estranha a boa parte dos debates relacionados a espaço urbano e arquitetura, na medida em que a abertura espacial é tomada como um valor também exclusivo. Entre políticos, a combinação de parcelas de convencimento com parcelas de coerção parece mais disseminada. ${ }^{46}$

Julgamos importante frisar estes nexos, porque eles aparecerão organizando as práticas cotidianas dos CEUs Butantã e Vila Rubi. No primeiro, as dificuldades para a promoção do acolhimento parecem em parte relacionadas a uma trajetória histórica que passa pela adoção exclusiva do convencimento e da livre escolha de ação e interação, terminando no outro extremo, com servidores excessivamente preocupados com a segurança e a organização. A história do segundo, veremos adiante, é menos marcada por rupturas e mais permeada por uma mescla de parcelas menores de coerção e maiores de convencimento e livre escolha.

A breve análise desses diversos discursos mostra que há uma associação frequente, mais ou menos intensa, entre incerteza e liberdade. Essa associação pode aparecer organizando dicotomias radicais - liberdade ou previsibilidade -, pode dizer respeito a uma etapa provisória num processo de emancipação - de acordo com educadores filiados à pedagogia da libertação - ou pode motivar uma dosagem de parcelas de convencimento e coerção. Todas as falas, no entanto, trabalham com uma mescla de preocupações que associa exercício direto do poder e criação de condicionantes para esse exercício. Nos termos propostos por esta pesquisa, há uma associação entre as intenções, ações e interações, de um lado, e os contextos em que se dão estas práticas.

Propomos agora olhar para essas questões com auxílio de uma lente mais restrita e precisa, recolocando os problemas para construir uma definição de contexto separador. Isto serve especificamente ao propósito de investigar condicionantes mais perenes das interações cotidianas, representados pela construção de espaços, de leis e de projetos e diretrizes pedagógicas em geral. Desse modo, é possível contrapô-los à variação mais vertiginosa e mais veloz das ações e das práticas cotidianas.

\footnotetext{
${ }^{46}$ Assim como o é entre certos teóricos que se dedicaram a pensar o Estado Moderno. A ideia está presente em Tilly (1996), mas uma versão canônica remonta às ideias de coerção e consenso em Antonio Gramsci - por exemplo, quando ele critica as ideias de Estado baseadas "no pressuposto de que todos os homens são realmente iguais e, portanto, igualmente razoáveis e morais, isto é, passíveis de aceitar a lei espontaneamente, livremente, e não por coerção" (GRAMSCI, 1980, p. 149). O autor considera, em seguida, a possibilidade de um Estado como "organização coercitiva" que, em condições favoráveis, poderá reduzir "gradativamente as suas intervenções" (ibid., p. 150).
} 
Procuramos desenvolver a noção de extensividade associando-a menos à produção de assimetrias de poder ou de igualdade, e mais à possibilidade da livre escolha por agir e interagir, ainda que o primeiro fator pudesse estar por vezes relacionado ao segundo. Esta limitação da abrangência do conceito foi pensada para que a extensividade pudesse transitar mais facilmente entre diversos âmbitos. Como vimos, o espaço não parece ter a mesma capacidade de construir e qualificar hierarquias quanto os dispositivos legais: as assimetrias de poder produzidas no âmbito do espaço constituem-se em grande medida em função das limitações de acesso, ou seja, em função do problema do livre trânsito, enquanto a linguagem escrita da lei consegue falar com mais eficácia sobre assimetrias.

Tendo em vista estas considerações, podemos falar de contexto separador sempre que algum aspecto da realidade impede ou dificulta o estabelecimento de interações entre as pessoas. No caso de um portão, a ativação da separação pode estar nas mãos de alguém ou de alguns; porém, se o controle da separação estiver disponível a todos os envolvidos numa dada situação, o contexto deixa de ser separador e passa a se tornar extensivo. Quando tal controle está nas mãos de um dos lados, ele tende a produzir assimetrias de poder, ou a reforçar assimetrias construídas em outros âmbitos, por normas legais, diretrizes pedagógicas e quaisquer outros meios. Mas muitos obstáculos (como paredes, escadas e mesmo aspectos geográficos como desníveis e distâncias) podem atuar como separações sem terem sido implementados com esse propósito, e podem não ser passíveis de reversão ou mudança. Nestes casos, a produção de hierarquias é mais ambígua, mas ainda pode ocorrer.

Pelos mesmos motivos que preferimos falar em termos de extensividade (e não em abertura), o termo separação é preferível a fechamento porque mais abstrato, não se relacionando a uma característica física específica (grandes distâncias podem separar tanto quanto um portão, sem que se constituam como um fechamento). Além disso, ao falar em separação evita-se uma conotação imediatamente negativa e estabilizada, como quando fala-se em fechamento. $\mathrm{O}$ que serve para indicar que as separações não devem ser associadas unicamente aos seus usos mais indesejáveis e polêmicos. A frequência com que as separações são usadas para, digamos, reforçar posições de poder tende a transmitir a ideia de que elas só podem ser associadas a esses usos, quando na verdade há um leque de efeitos diversos (da mesma forma como observamos para as extensividades). 
Em primeiro lugar, nunca é demais lembrar que as separações são comumente usadas para reforçar hierarquias de poder, para impedir que um grupo interpele ou se aproxime de outro, ou para garantir a posse de espaços ou privilégios. Há motivos de sobra para que pesquisas urbanas apontem para o cerceamento de espaços públicos de encontro (CALDEIRA, 2000); para que as salas fechadas de escritórios corporativos sejam comumente associadas a hierarquia de poder e status (DALE; BURRELL, 2010); para que os fechamentos de escolas sejam denunciados como formas de controlar a conduta dos alunos diante da ausência e da desistência de diálogo entre educadores e educandos (PEREIRA, 2010; OLIVA, 2010). Mas esses efeitos podem estar associados a consequências desejáveis: uma delas é a redução da incerteza - e aqui as separações nos revelam uma das limitações da extensividade. Além disso, assim como observamos que a abertura espacial em ambientes corporativos pode facilitar o monitoramento de empregados, as separações podem ser usadas a favor de grupos subalternos em disputas de poder ${ }^{47}$.

Outro conjunto de efeitos relacionados às separações não passa diretamente pela produção de hierarquias de poder, mas pela delimitação de um domínio próprio, pela construção de autonomia de uma pessoa ou grupo, ou ainda pela garantia de privacidade sem que isso se constitua necessariamente como privatismo ou apropriação indébita. Com base em Hannah Arendt, Leite (2004, p. 135) sugere entender a esfera privada como "salvaguarda do excesso de exposição do mundo público". Sennett (1974), por sua vez, sugere que "os seres humanos precisam manter certa distância da observação íntima por parte do outro para poderem sentir-se sociáveis". Assim, as separações podem estar envolvidas na produção de debates e interações públicas mais qualificadas, na medida em que proporcionam às pessoas e grupos um espaço privado para o fortalecimento de sua autonomia e poder de voz. Ficam evidentes as limitações das extensividades na produção deste outro conjunto de efeitos.

Esses problemas aparecem na pesquisa do arquiteto e antropólogo Carlos Nelson Ferreira dos Santos (1981), que etnografa sua própria proposta de projeto para um edifício que abrigaria a associação de moradores da favela Brás de Pina. No Rio de Janeiro dos anos 1970, essa favela passa por uma urbanização em parte conduzida pelo próprio autor:

\footnotetext{
${ }^{47}$ Talvez o exemplo mais clássico discutido no campo da arquitetura seja o que envolve as reformas de Paris no século XIX pelo Barão de Haussmann. Um dos propósitos da abertura de grandes avenidas no tecido urbano de Paris era o de facilitar o acesso de tropas e dificultar as táticas de entrincheiramento em ruas e casas de bairros populares, por parte dos levantes revolucionários da época (BENÉVOLO, 1989, p. 96; BENJAMIN, 1997, p. 76 apud LEITE, 2004, p. 110). Ou seja, nem sempre a abertura espacial está a favor da simetria de poderes.
} 
fica na dúvida se o que queríamos fazer resultaria em algo melhor do que o que acabou saindo. Queríamos que fosse construído um edifício aberto, com espaços indefinidos entre o público e o privado, o que, junto com a localização central, indicaria ao conjunto da população que ali estaria a sua casa, o centro de seus interesses, representação da sua unidade e de seu espírito coletivo. Em suma: também havíamos caído no engodo de uma Associação metonímica que seria eternamente a bandeira da comunidade. Hoje a praça está em parte cercada e serve para partidas de futebol, para ensaios de um bloco, para reuniões de "bíblias". (SANTOS, 1981, p. 79, grifos nossos)

Santos está apontando aí para uma relação aparentemente contraditória entre a promoção de atividades comunitárias do interesse da favela Brás de Pina e o fato de essas atividades terem se desenvolvido em conjunto com o cercamento de espaços, graças à atuação de um morador associado a vereadores locais. O incômodo que sente deve-se justamente à incompatibilidade entre a realidade observada e a dicotomia teórica que, na maior parte do livro, organiza muitas das análises: trata-se do par interesses individualistas/espírito comunitário, o primeiro conotado negativamente e associado a fechamentos de espaço, e o segundo conotado positivamente e associado a espaços compartilhados. Este excerto é interessante para fecharmos a discussão proposta porque revela com clareza o descompasso entre a realidade observada e a tentativa de interpretá-la com base numa dicotomia maniqueísta de posições extremas e mutuamente excludentes. Isso dificulta debates que poderiam lidar com problemas de dosagem e combinação de contextos.

Nos campos da arquitetura, do espaço urbano ou da pedagogia há maior relutância do que naqueles de cunho jurídico ou político em reconhecer papéis positivos para as separações: nestes últimos, é fácil aceitar a ideia de que nossas democracias não funcionariam sem um mínimo de proibições ou hierarquias que certamente contrariam o valor da liberdade e as vontades de muita gente. Quando nos voltamos para problemas de espaço ou de pedagogia, o campo da discussão encontra-se de certa forma limitado por uma outra geografia de valores e referências, como viemos observando. Podemos perceber o ponto com clareza justamente porque nossa discussão sobre contextos trata de sobrepor problemas análogos situados em campos de estudo e atuação diversos, levando às últimas consequências a intenção já manifestada por nossos sujeitos de pesquisa em estabelecer afinidades entre problemas de arquitetura, de política e de pedagogia. 


\subsection{Intensividades}

Os tópicos precedentes construíram uma distinção entre dois tipos de contexto com base na problematização de dicotomias bastante conhecidas: aberturas e fechamentos de espaço, descentralização e centralização de poder, práticas pedagógicas tidas como libertárias e aquelas tidas como opressoras. Constatamos que esses condicionantes não produzem efeitos tão precisos nas dinâmicas interacionais, e que eles não precisam ser organizados numa leitura unívoca, que reuniria efeitos desejáveis, de um lado, e indesejáveis, de outro. Os eventuais binarismos sairão mais enfraquecidos com a reflexão sobre um terceiro tipo de condicionante das interações cotidianas. As intensividades não são tão conscientemente problematizadas quanto os outros dois tipos de contexto, e estão presentes de modo mais sutil nos discursos e práticas anteriormente apresentados. Por estarem relacionadas à incerteza e à efetivação de interações, elas se assemelham às extensividades, estando muitas vezes contidas nas defesas da abertura espacial. Ainda assim, contextos intensivos são muito diferentes dos extensivos, porque tendem a produzir interações de tipo não voluntário - e, neste aspecto, as intensividades são semelhantes às separações. Prosseguiremos com o exercício tentando delimitar o leque de efeitos relacionados às intensividades. Se as separações nos ajudaram a observar limitações da extensividade, as intensividades apontarão outras.

Ao tratar das extensividades, observamos como a abertura espacial foi associada às noções de convívio e diálogo, à garantia da liberdade de agir e interagir. No entanto, em certos momentos a defesa de espaços abertos parece mudar de tom: os comentários passam a admitir a ideia de que o espaço pode e deve intervir no modo como se dão as interações, e no limite mostram-se dispostos a contradizer a vontade e a liberdade das pessoas em prol de intenções e valores que consideram desejáveis. Com a intensividade, o espaço ganha legitimidade para incentivar ou forçar a interação. 


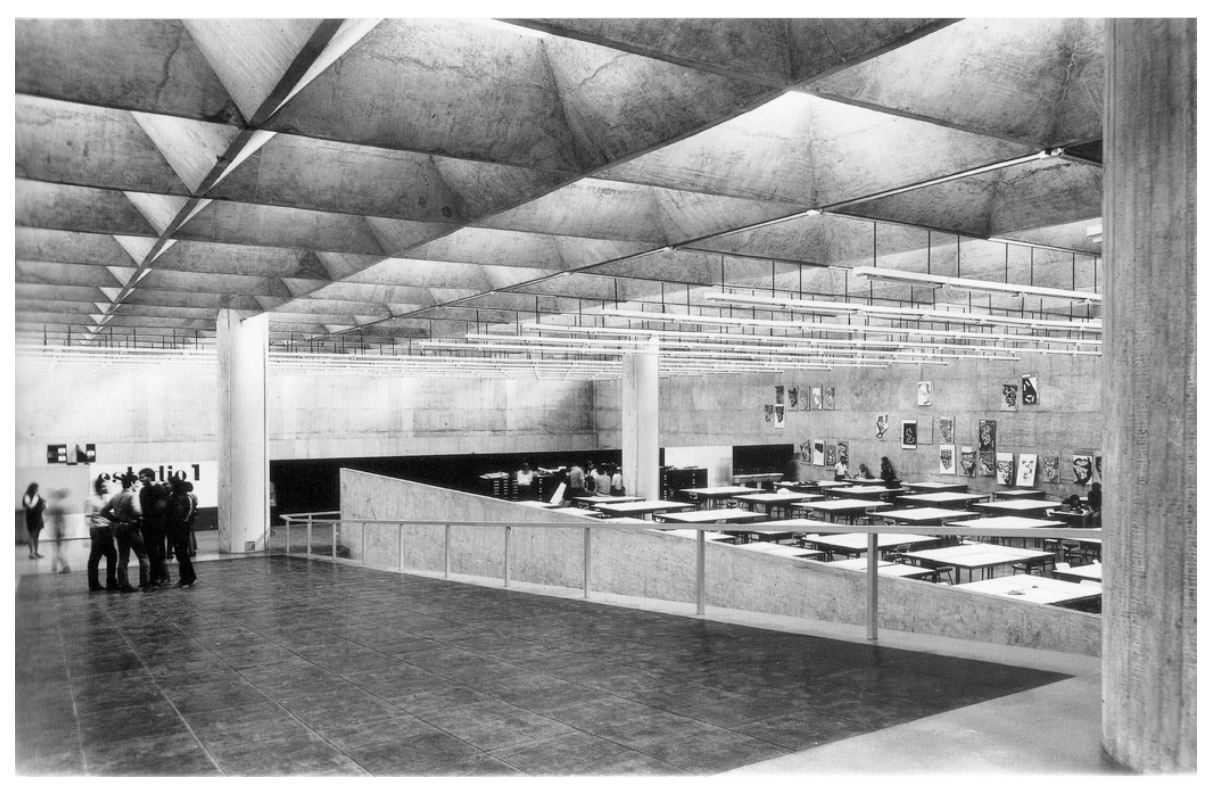

Figura 19 - Estúdios da FAU-USP, com rampa de circulação em primeiro plano. Fotografia de autoria desconhecida. Extraído de Ferraz (1997, p. 111).

Para mostrarmos como as intensividades aparecem associadas às extensividades, consideremos a justificativa do arquiteto Vilanova Artigas para o projeto de um dos edifícios mais importantes da arquitetura paulistana, o da Faculdade de Arquitetura e Urbanismo da USP (FAUUSP), construído entre 1961 e 1968 no campus da Universidade de São Paulo ${ }^{48}$. A citação abaixo é exemplar nessa direção:

O prédio da FAU, como proposta arquitetônica, defende a tese da continuidade espacial. [...] aumenta o grau de convivência, de encontros, de comunicação. Quem der um grito, dentro do prédio, sentirá a responsabilidade de haver interferido em todo o ambiente. Aí o indivíduo se instrui, se urbaniza, ganha espírito de equipe. [...] Este prédio acrisola os santos ideais de então: pensei-o como a espacialização da democracia, em espaços dignos, sem portas de entrada, porque o queria como um templo, onde todas as atividades são lícitas. (ARTIGAS apud FERRAZ, 1997, p. 101, grifos nossos)

As palavras de Artigas relacionam "continuidade espacial" à "espacialização da democracia" de forma um tanto livre e ambígua. Em uma análise mais detida, podemos encontrar duas dinâmicas espaciais distintas que, no entanto, aparecem mescladas: de um lado, temos um edifício "sem portas de entrada", que favorece a livre circulação das pessoas; de outro lado, Artigas usa o

\footnotetext{
${ }^{48}$ Vale lembrar que os autores do primeiro projeto dos CEUs (os arquitetos Alexandre Delijaicov, Vanderley Ariza, André Takyia) inserem-se na linhagem de arquitetos que tem em Artigas uma de suas principais inspirações e na abertura espacial um importante elemento de sua poética (SERAPIÃO, 2012, p. 46).
} 
exemplo de um "grito" para mostrar que a continuidade dos espaços no edifício da FAU-USP supostamente obrigaria seus frequentadores a se respeitarem mutuamente, adquirindo "espírito de equipe" - termo muito próximo da noção mais clássica de espírito cívico. Esta dimensão é menos tratada pelos comentadores e mais dificilmente associável a práticas democráticas, na medida em que sugere a possibilidade de que a abertura espacial induza a interações, mesmo contra a vontade dos sujeitos.

Mas o excerto de Artigas toca muito sutilmente nessa questão, que é bastante evidente para aqueles que frequentaram regularmente o edifício da FAU-USP por algum tempo. Para essas pessoas, dentre as quais me incluo, não seria difícil concordar que o exemplo do "grito" é apenas um caso extremo de interações humanas afetadas de modo constante pela continuidade dos espaços internos. Talvez o exemplo mais comum refira-se à impossibilidade de selecionar encontros ao longo das rampas de circulação principal do prédio. Quando estudante, lembro-me da ironia de certos comentários de pessoas que se divertiam com a natureza inevitável desses encontros. Se a pressa e outros motivos pessoais impunham a necessidade de evitá-los, uma solução drástica era tomar as escadas, que ficavam na outra extremidade do edifício e que, pela longa distância, cobravam um preço que valia a pena ser pago.

Vemos assim que, por um lado, a abertura espacial pode entregar às pessoas a liberdade de escolher para onde ir e com quem se encontrar; por outro, pode retirar delas o poder de evitar a interação. Posto desta forma, tratamos de duas dinâmicas contraditórias, associadas à ideia de interações voluntárias e não voluntárias - este é outro motivo para declinarmos do emprego do termo abertura e passarmos a utilizar os termos intensivo e extensivo.

Um segundo exemplo trata mais exclusivamente da intensividade e pode ser encontrado no projeto dos CIEPs. Neste caso a abertura espacial aparece na proposta de construção de paredes divisórias de meia altura (sem alcançar o teto) entre as salas de aula - tal como me foi relatado pela educadora Anna Cecília Simões, que na época fazia parte da rede pública de ensino carioca. ${ }^{49}$ Lembremos que o projeto dos edifícios foi desenvolvido pelo arquiteto Oscar Niemeyer, com participação do educador e antropólogo Darcy Ribeiro, nos anos 1980, o que mostra que a proposta da meia parede relaciona discussões no plano da pedagogia e da arquitetura.

\footnotetext{
${ }^{49}$ Os relatos abaixo baseiam-se em depoimentos de Anna Cecília Koebcke de Magalhães Couto Simões, gestora do CEU Butantã durante a gestão de Marta Suplicy e educadora participante da implementação dos CEUs em São Paulo (2001-2004) e dos CIEPs no Rio de Janeiro, estes últimos sob os governos de Leonel Brizola (1983-1986 e 19911994). As entrevistas com Anna Cecília foram por mim realizadas nos dias 23/05/2013, 06/06/2013 e 19/07/2013.
} 


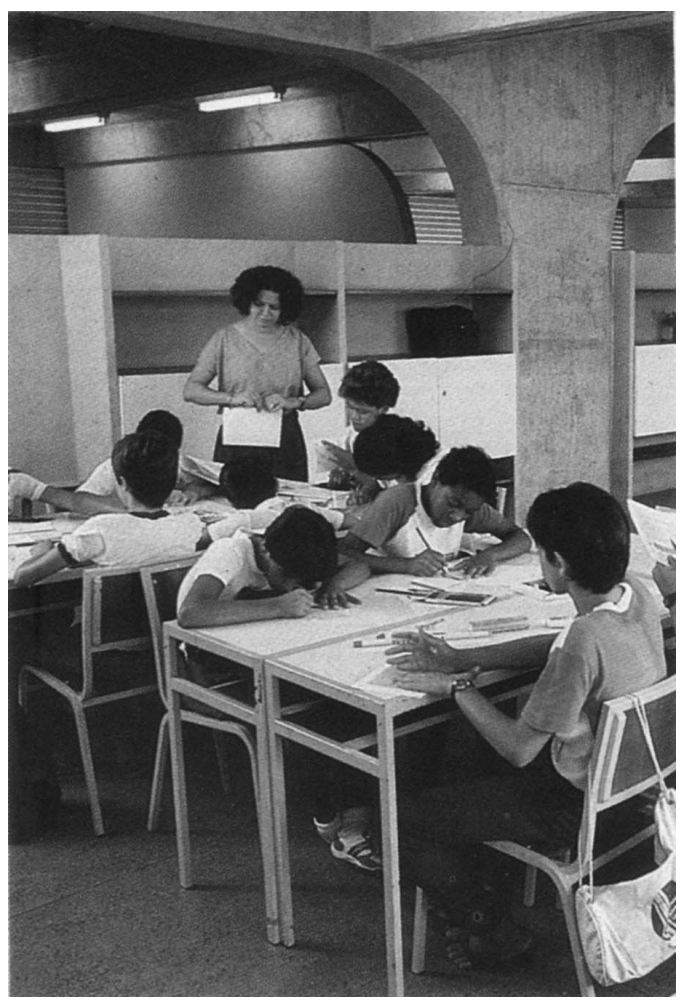

Figura 20 - Salas de aula com meia parede, dos CIEPs. Autoria desconhecida. Extraída de Ribeiro, 1986.

Durante os debates públicos para construção dos CIEPs, a meia parede teria gerado uma grande polêmica entre os educadores. Boatos e acusações surgiram, dentre eles o de que as paredes tinham sido construídas à meia altura porque o governo Brizola pretendia economizar com gastos de obra. Diante das controvérsias, Darcy Ribeiro convocou uma conferência aberta a todos os educadores da rede. Esses encontros na época aconteciam com certa frequência, reunindo milhares de pessoas, e tinham lugar no Maracanã, no Riocentro (Centro de Convenções) e em outros edifícios de escala semelhante. Outros assuntos também seriam abordados, até que o problema da meia parede foi levantado, trazendo uma confusão de protestos e comentários proferidos em tom exaltado. Diante disso, Ribeiro pede a palavra para explicar-se, prosseguindo com uma fala propositalmente baixa e compassada, reproduzida nos seguintes termos por Anna Cecília Simões:

Educação se faz a meia-voz. Educação se faz a meia-voz. E com múltipla inspiração. Se educação se faz a meia-voz, e com múltipla, e mútua, e recíproca, inspiração, nos CIEPs, que são a revolução da Educação, não pode se abrir mão nem da meia-voz, nem da múltipla inspiração. Então, queridos, não cabe outra coisa nessa revolução de 
educação se não a meia parede. Porque é a meia parede que vai nos permitir fazer uma educação a meia-voz, e absolutamente, reciprocamente inspirada. Umas nas outras, um olhando o outro, um se inspirando no outro, e um respeitando o outro, e aproveitando o que o outro está dizendo, e incorporando e discutindo. (conforme relato de Anna Cecília Simões, concedido a mim em 19/07/2013)

Neste excerto, o problema da indução de interações aparece de modo muito mais claro e delineado, não se confundindo com a proposta de ausência de portas de entrada, como vimos em Artigas. Se o exemplo do "grito" evoca situações conflituosas, o exemplo da "meia-voz" evoca situações mais consensuadas, mas ambos admitem vantagens nos convívios forçados.

Voltando ao primeiro projeto dos CEUs, a intensividade aparece de modo exemplar nas polêmicas surgidas com a decisão dos arquitetos em aproximar, no bloco educacional, espaços e atividades tidos por muitos como incompatíveis. Por exemplo, no CEU Butantã, alguns funcionários e usuários da biblioteca ressentiam-se do barulho causado pela proximidade com as piscinas, situadas ao lado, e com o pátio da EMEF, situado um andar acima - conforme indicado na figura 9. Alguns professores da EMEF também reclamavam da possibilidade de os alunos observarem e ouvirem o barulho das atividades da piscina. O arquiteto Delijaicov, no entanto, observa que essa aproximação de usos foi intencional e atribui a esses professores uma visão retrógrada e tradicional da prática educativa:

Eu ouvi isso: "Ah, mas vocês fizeram isso, e ainda por cima janela baixa, a janela tem que ser alta!". Olha só, o educador: "a janela tem que ser alta, tem que ter acima de 2 metros de altura para a criança não olhar para fora, o jardim bonito". Pô, qualquer um sabe, quem projeta biblioteca, que as paisagens, você tem a paisagem da literatura e a paisagem do olhar periférico - aliás o Anísio Teixeira falava disso, a escola-parque é isso, você estar em um ambiente com integração visual interior e exterior. Aí chega esse educador e tem coragem de falar... quer dizer, não tem nenhum constrangimento, nenhum pudor. Imaginar que tem que ser [janela] alta... imagina que [ao] ouvir a gritaria e a algazarra das crianças que estão se divertindo com a piscina [ele diga:] "como é que eu posso dar aula?", indignado. Então ele tem que ser diferente, não pode dar aula mecânica. (DELIJAICOV, depoimento de outubro de 2010)

Na medida em que a "integração" entre interior e exterior oferece aos alunos a possibilidade de olhar para fora da sala de aula, atua no sentido observado no tópico sobre extensividades, maximizando liberdades de escolha e reforçando as propostas da pedagogia da libertação de Paulo Freire. Este não é o ponto que propomos desenvolver aqui, e sim aquele relacionado à capacidade 
que a "integração" teria de forçar o professor a ministrar uma aula de melhor qualidade. ${ }^{50}$ Nossa intenção em frisar esse raciocínio não é a de defender o ponto de vista do arquiteto nem o do educador supostamente contrariado, mas a de observar que uma das justificativas para a implementação da abertura espacial distancia-se muito da que observamos anteriormente. Neste caso, enxerga-se de modo positivo a contradição das intenções das pessoas.

O segundo projeto de arquitetura dos CEUs também parece ter incentivado as intensividades, na medida em que distribuiu os equipamentos do CEU numa quantidade maior de pequenos volumes que exigiram recuos e espaços intersticiais entre si. Ao menos no CEU Vila Rubi, essa decisão tendeu a reduzir significativamente os espaços disponíveis para ocupação, trazendo um aumento na concentração de pessoas e nas quantidades de interações entre elas. Fica claro que a intensividade não é produzida apenas por aberturas de espaço, mas também por redução de área, dentre outros fatores.

No âmbito dos dispositivos legais, os contextos intensivos são todos aqueles que determinam compartilhamento de responsabilidades e execução de tarefas em equipe. Uma forma particularmente frequente de intensividade está na simples existência de vínculos empregatícios que exigem o convívio entre colegas e grupos de trabalho. Nesse sentido, as intensividades estavam bastante presentes no primeiro regimento dos CEUs, na medida em que o Conselho Gestor e o Colegiado de Integração precisavam reunir diversos profissionais para tomar decisões administrativas importantes. Ao diminuir a frequência e a importância desses grupos, o segundo regimento reduziu não apenas os vínculos não imprescindíveis, constituidores de extensividade representados pelas linhas pontilhadas do organograma, conforme já observamos -, como também os de cunho imprescindível, constituidores de intensividades. Assim, a delimitação de responsabilidades e atribuições mais exclusivas não apenas aumentou os contextos separadores, como também fez com que eles passassem a predominar no âmbito legal - na medida em que os outros dois tipos de contexto diminuíram.

\footnotetext{
${ }^{50} \mathrm{O}$ tensionamento de posições entre arquiteto e professor em torno da abertura das salas de aula já aparece num depoimento de Hélio Duarte, que, como vimos, foi um dos autores do projeto arquitetônico da escola-parque: "Separando as escolas, separando as classes, a série de paredes fechadas deveriam ser substituídas por paredes de vidro, como aquários. Muitas vezes ouvi que as escolas modernas eram atacadas por esse lado pelos professores. Continham muito vidro, os alunos ficavam olhando mais para fora do que se interessavam pelas aulas. A minha resposta sempre foi esta: 'Se a escola não consegue interessar a criança, então não ensine nada a ela. Ela aprende muito mais lá fora do que dentro da escola. Agora, se a escola interessa, se o aluno se interessa, se o aluno se interessa pela escola - esse problema é do professor, não do arquiteto." (DUARTE, 1973, p. 161-162)
} 
Um último ponto para completar a compreensão das mudanças de regimento em termos de contexto refere-se ao aumento das intensividades relacionadas ao já observado incremento de hierarquias de poder. ${ }^{51}$ Contextos intensivos são absolutamente centrais para entender o cotidiano escolar de um modo geral, já que a frequência à escola é obrigatória para crianças e jovens. Além disso, por serem regulados por sistemas de pontuação e premiação de longo prazo, os vínculos empregatícios de funcionários e professores da rede pública envolvem perdas significativas de vantagens para demissionários, de modo que coagem mesmo os descontentes a prosseguir na carreira. Dessa forma, tanto alunos quanto professores encontram-se submetidos a intensividades importantes, que se somam às significativas separações já mencionadas para produzir os dois tipos de contexto não voluntários aqui propostos. Isso contrasta significativamente com a vocação de um centro educacional para a extensividade e agrega mais motivos para considerarmos diferenças cruciais entre CEUs e escolas (voltaremos à questão no próximo capítulo).

Para propor uma forma de entender o tipo de influência representado pelos contextos intensivos, façamos referência a uma discussão oriunda do campo da ciência política, referente ao estudo de organizações e associações entre grupos de pessoas. Ao estudar os efeitos democráticos de associações entre cidadãos, Hirschman (1970) e Warren (2010) trabalham com a ideia de laços voluntários e não voluntários. Segundo eles, os primeiros foram valorizados, no interior de uma tradição toqueviliana de pesquisadores, por não oferecerem restrições à liberdade dos indivíduos. De algumas décadas para cá, novas pesquisas passaram a aprofundar este debate, chamando atenção não tanto para a livre escolha em associar-se, mas para a livre escolha em desassociar-se, implícita na primeira. Oferecendo poucas barreiras à desfiliação, as associações voluntárias teriam maior tendência a resolver seus conflitos internos com a saída dos descontentes. Estes se dirigem, por sua vez, a outras associações, produzindo um mecanismo de reagregação de interesses de tipo mercadológico, no âmbito inter-associativo. Como observam os autores, nessas associações as pessoas "votam com seus pés". Mas essa dinâmica produziria, no âmbito interno de uma associação voluntária, maior homogeneidade de posicionamentos entre seus integrantes e menos oportunidades para a deliberação coletiva. A diminuição de controvérsias internas tenderia a

\footnotetext{
${ }^{51} \mathrm{Em}$ termos de contexto, os vínculos assimétricos parecem compreensíveis tanto como intensivos - principalmente se pensarmos na possibilidade de um superior travar contato com um subordinado - quanto como separadores sobretudo no sentido oposto, referente às chances de um subordinado ter acesso a um superior. Isso mostra que os contextos podem mudar de natureza conforme a condição particular de um e outro dos envolvidos, mesmo que ambos constituam uma única relação. Se levássemos esta ideia às últimas consequências, perderíamos a concisão dos conceitos aqui propostos - vale mencioná-la como inspiração para outros trabalhos.
} 
expandir os consensos entre associados, criando um ambiente amistoso que favoreceria o desenvolvimento de virtudes cívicas, entendidas de um modo geral como disposições favoráveis dos indivíduos com relação aos seus semelhantes - cooperação, reconhecimento de direitos e diferenças, relações de reciprocidade e confiança.

As associações não voluntárias, por seu turno, em geral malvistas pela literatura sobre associações, seriam responsáveis pela produção de outros efeitos democráticos. Quando os filiados só podem sair mediante altos custos - financeiros, mas também de tempo, de status, e quaisquer outros - ou quando eles simplesmente não podem sair - como no caso da filiação ao próprio Estado Moderno -, tende-se a uma maior pressão interna pelo poder de voz, e a deliberação coletiva torna-se uma questão mais relevante dentro do âmbito associativo. Surgem situações de conflito que são desfavoráveis ao desenvolvimento das virtudes cívicas que mencionamos acima, mas que incentivam habilidades críticas - relacionadas à capacidade de realização de juízos autônomos - e habilidades políticas - falar, negociar, coligar-se, comprometer-se, reconhecer manobras de poder, entre outras. Uma das conclusões de Warren é a de que uma democracia deveria inserir seus cidadãos em uma ecologia de tipos de associações, onde pudessem se exercitar em diferentes conjuntos de virtudes.

Aproximando livremente autores de procedências distintas, podemos observar ideias contraditórias em Artigas e Warren: enquanto o primeiro sugere a formação de um "espírito de equipe" sob condições de convívio forçado, o segundo considera o predomínio de virtudes cívicas em interações voluntárias. O raciocínio de Warren parece mais convincente quando restrito ao âmbito interno das associações, mas dá pouca atenção às consequências no âmbito interassociativo. De qualquer forma, ambos os autores estipulam uma correlação direta entre duas variáveis precisas, num estilo de reflexão pouco compatível com uma pesquisa etnográfica e pouco produtivo para interpretar os achados de campo que apresentaremos nos próximos capítulos. Se o cotidiano escolar aparece muitas vezes como permeado por uma grande quantidade de animosidades, isso mostra que mesmo pessoas impelidas ao convívio por muito tempo não são necessariamente levadas a transigir de suas posições antagônicas e a efetivar acordos satisfatórios. Enfim, a intensividade (como os outros tipos de contexto) não parece estar relacionada à produção de efeitos muito precisos para as interações cotidianas; portanto, também não podemos considerála como necessariamente desejável ou indesejável. Novamente: isso não significa que a influência dos contextos seja irrelevante, mas sim que os efeitos por eles produzidos são muito menos 
precisos do que geralmente se supõe.

Mas como podemos nos endereçar ao leque de efeitos produzidos nas interações cotidianas pela presença de contextos intensivos? Uma pista para esta resposta está na forma como Warren qualifica as interações voluntárias. Se as extensividades permitem que as interações sejam escolhidas pelas pessoas, elas também dão margem para a desistência das interações. Interações opcionais podem levar a interações infrequentes ou mesmo inexistentes - este nexo será muito importante para entendermos a história do CEU Butantã. Nesse sentido, as extensividades podem ser aproximadas das separações: nas primeiras, os afastamentos existem como possibilidade, enquanto nas segundas eles existem como necessidade. Mas, em ambos os casos, há uma tendência para a constituição de intermitências ou desacelerações. As desacelerações podem chegar ao ponto de produzir a estagnação da política das interações cotidianas; por outro lado, podem relacionar-se com o reforço da autonomia e dos valores próprios de pessoas e grupos, já que estes passam a contar com um certo resguardo para consolidar suas posições. A intensividade aparece, assim, como o único tipo de contexto capaz de produzir acelerações nas dinâmicas interacionais. Fica claro que, quando falamos em aceleração, nada sabemos sobre o rumo efetivamente tomado pelas dinâmicas interacionais, e não podemos, portanto, considerar antecipadamente as intensividades como desejáveis ou indesejáveis. Nesse sentido, tanto os contextos intensivos quanto os extensivos estão relacionados à produção de intercâmbios e incertezas, opondo-se à maior previsibilidade das separações.

\subsection{Sobre a tipologia e além dela}

Neste capítulo analisamos a correspondência entre projetos arquitetônicos, políticos e pedagógicos, bem como as intenções daqueles que estiveram envolvidos em sua concepção e implementação. Mais particularmente, observamos que a abertura espacial, a descentralização administrativa e as diretrizes da pedagogia da libertação constituíram-se dentro de um tensionamento dicotômico entre partidários e adversários. Nisso, tenderam a construir divisões correspondentes entre os meios empregados por uns e outros: certos contextos passam a ser considerados como sinônimos de certas práticas. A análise aqui proposta sugere que os contextos 
não são capazes de influenciar as dinâmicas interacionais numa direção muito precisa, estando associados a um leque de efeitos que não pode ser considerado apenas desejável ou indesejável.

Isso não quer dizer que os contextos não sejam importantes para as interações cotidianas, apenas que o acolhimento não é produzido exclusivamente pela maximização de extensividades. Mesmo que estejamos inclinados a favorecer as extensividades, podemos contar com parcelas dos outros dois tipos de contexto. Ao pensar em complementaridades dos contextos, somos levados a pensar também em variações de dosagem ao longo do tempo em processos gradativos de mudança; ao lado disso, quando nos dedicamos exclusivamente a maximizar extensividades, almejamos uma situação futura, idealizada e permanente, sem que isso suscite um raciocínio processual a respeito de como chegar até ela e de como lidar com problemas do tempo presente (desenvolveremos este ponto no final da pesquisa).

Faremos agora um esforço para resumir o esquema montado para os contextos. A intenção não é a de enrijecê-los ou transformá-los numa camisa de força, mas apenas de esclarecer pontos que porventura tenham ficado nebulosos. O modo como os conceitos de contexto serão mobilizados nos próximos capítulos deixará claro que eles podem ser manipulados livremente, a serviço da compreensão de situações concretas a partir das quais foram concebidos. Nas interações cotidianas, os contextos não cessam de se combinar entre si em proporções diversas e não param de remeter a outros tipos de problema, de modo que eles constituem ferramentas úteis para o entendimento de dinâmicas particulares.

Dito isso, segue um diagrama explicativo dos três tipos de contexto propostos: 


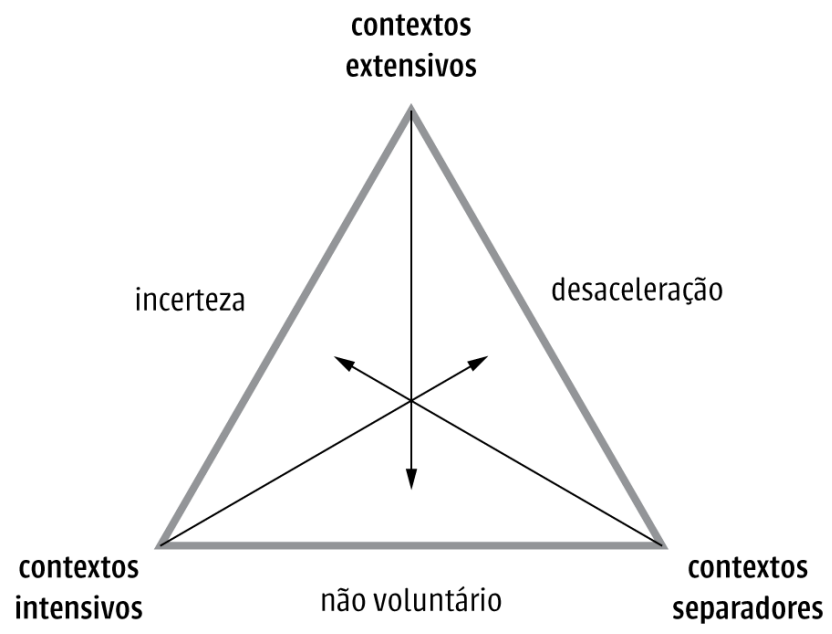

Figura 21 - Diagrama de contextos.

O diagrama associa cada lado do triângulo a uma característica compartilhada pelos dois vértices que o determinam: intensividades e separações assemelham-se pela produção de dinâmicas interacionais não voluntárias; as separações e as extensividades estão envolvidas com a produção de desacelerações; extensividades e intensividades relacionam-se com a produção de incerteza. Além disso, as características relacionadas a cada lado do triângulo estabelecem um contraponto com um atributo exclusivo do contexto situado no vértice oposto. Podemos deduzir, assim, que contextos extensivos são os únicos que garantem a livre escolha em agir e interagir; contextos intensivos distinguem-se pela capacidade de produzir acelerações e os separadores relacionam-se à garantia de previsibilidades.

Em termos abstratos, a extensividade pode ser mais desejável, mas a forma como se concretiza em cada situação deve servir de base para avaliações mais específicas. Um excesso de extensividades pode produzir incertezas indesejáveis, assim como ocorre com as intensividades, ${ }^{52}$ e nesses casos certa dose de separações pode se justificar.

\footnotetext{
${ }^{52} \mathrm{Em}$ alguns casos pode ser interessante diferenciar as incertezas produzidas por extensividades e intensividades. Num certo sentido a incerteza das intensividades é menor, já que, se não sabemos do resultado das interações, sabemos ao menos que elas devem ocorrer. Sob extensividades, desconhecemos tanto o resultado quanto a efetivação das interações. Mas quando intensividades presidem conflitos, podem ser altamente incertas, de modo que não é possível generalizar. Outra observação interessante da relação entre estes dois contextos: duas pessoas em relação extensiva podem optar pela aproximação; porém, quando apenas uma o faz, a escolha da outra pela não interação é momentaneamente cerceada - para todos os efeitos, ela passa a se encontrar num contexto intensivo.
} 
Além disso, as extensividades definem encontros facultativos que podem levar a desacelerações maiores ou menores das dinâmicas interacionais. Se a desaceleração existe como uma possibilidade inerente às extensividades, as separações a tornam inevitável. No entanto, independentemente de serem qualificadas como possíveis ou inevitáveis, as desacelerações podem estar presentes em ambos os contextos, em maior ou menor intensidade. Produzem resultados variados, que vão desde a manutenção de distâncias relativas necessárias ao reforço de autonomias e identidades, até afastamentos permanentes que produzem a estagnação das dinâmicas interacionais. As intensividades, por sua vez, são as únicas capazes de combater esses efeitos, mas as acelerações por elas produzidas não necessariamente levam à efetivação de acordos ou entendimentos mútuos, podendo até mesmo agravar conflitos.

Outra forma de representar contextos de âmbito espacial pode ser útil para ilustrar como eles não estão associados a características físicas precisas, e, ainda, como os limites entre eles podem não ser fixados com exatidão.
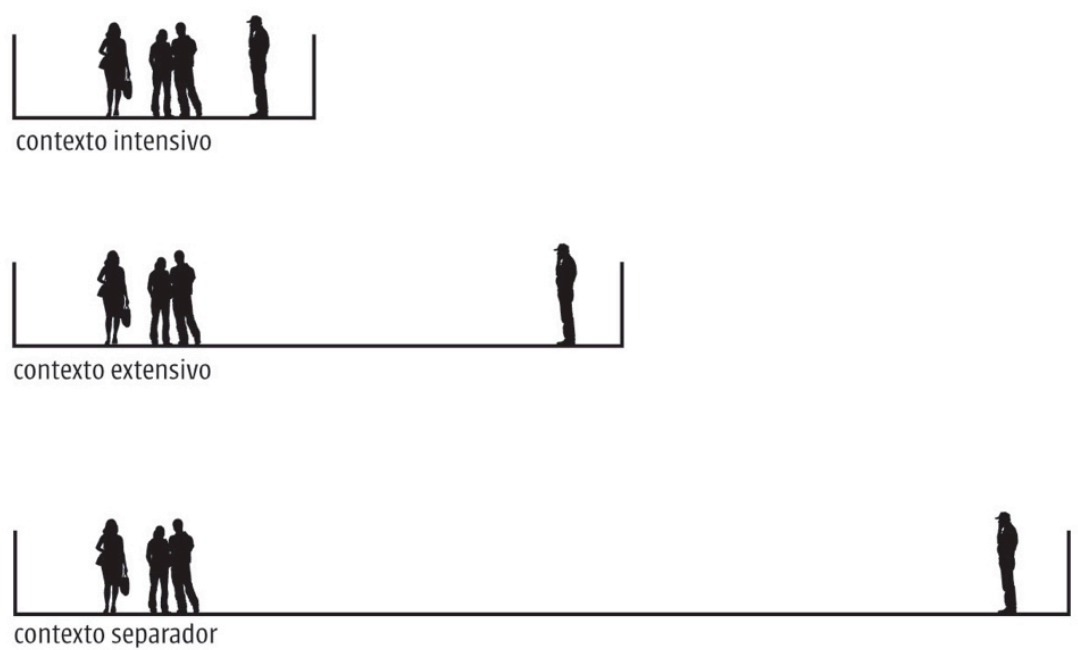

Figura 22 - Tipos de contexto em função de distâncias.

Nesta primeira figura, o tipo de contexto varia conforme o tamanho do espaço: quando as pessoas não podem manter distâncias muito grandes umas das outras, tem-se a produção de uma intensividade; quando a distância é muito grande, há dificuldades para travar contato e produzemse separações. Quando as distâncias são intermediárias, os contatos interpessoais são facultativos. 
Fica claro que os limites entre a conformação de um e outro contexto podem ser tão imprecisos a ponto de fazer com que sua classificação dependa muito do ponto de vista das pessoas. Uma dada situação pode ser considerada extensiva por uns e intensiva por outros, e assim por diante. Assim, as qualificações de contexto não podem ser feitas em termos puramente objetivos, e devem levar em conta o modo como as pessoas envolvidas numa interação entendem a realidade em que estão inseridas.

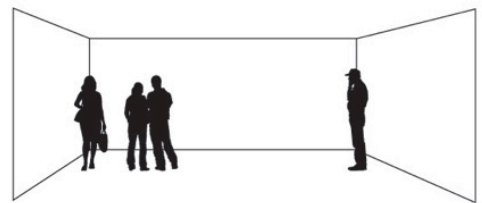

contexto intensivo

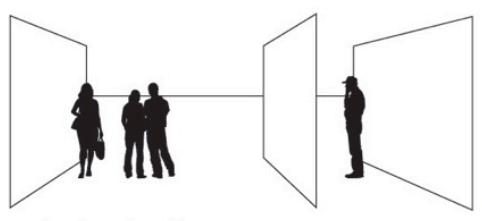

contexto extensivo

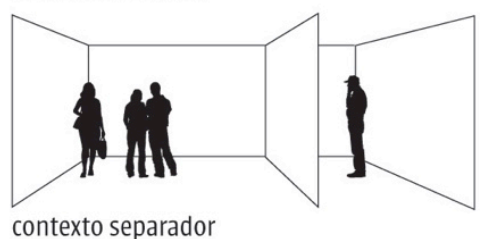

contexto separador

Figura 23 - Tipos de contexto em função de configurações de abertura e fechamento espacial.

Esta segunda figura indica que o tipo de contexto também pode variar em função da forma como se dispõem obstáculos físicos entre as pessoas. Contextos intensivos podem ser produzidos pelo convívio dentro de um ambiente fechado ao exterior e ausente de separações internas. Por sua vez, as separações podem ser formadas por obstáculos que impedem as pessoas de se aproximar; já a extensividade pode ser produzida pela presença de um fechamento que pode ser facilmente contornado por aqueles que desejam travar interação, ao mesmo tempo que garante a outros a possibilidade de evitá-la. Os dois primeiros desenhos mostram como a imagem da abertura espacial suscita uma confusão entre extensividade e intensividade (confusão indicada no excerto anteriormente mencionado de Artigas), na medida em que não especifica se a abertura é interna a um ambiente fechado - caso em que produz intensividade - ou se a abertura configura um ambiente aberto. 
Parece claro que espaços tais como se apresentam no mundo precisam ser observados com cautela. Essa observação deve levar em conta uma combinação de características diversas dos espaços, relativas não só aos seus tamanhos e ao posicionamento de eventuais obstáculos, mas também à natureza desses obstáculos - visuais, corporais, auditivos etc. -, assim como aos desníveis existentes entre eles, aos seus significados, entre outros aspectos. Além disso, para entender as dinâmicas interacionais precisamos considerar as formas como essas propriedades de espaço se combinam entre si e com outros tipos de contexto de âmbito temporal, legal, pedagógico, cultural e assim por diante. Na medida em que olhamos apenas para o espaço ou para algum outro âmbito isolado, corremos o risco de não identificar relações de complementaridade, contraponto, intersecções parciais, disjunções etc. A tarefa pode parecer difícil, mas num certo sentido nós já estamos mais do que habituados a realizá-la em nossas práticas cotidianas - esta pesquisa pretende contribuir para esclarecer as variáveis em jogo.

Finalmente, é importante lembrar que a análise de interações e contextos traz ferramentas importantes para o acolhimento, mas há outros fatores relevantes que não recebem tratamento central nesta pesquisa: clivagens socioeconômicas, características das comunidades e dos bairros no entorno dos CEUs, relações de poder com instâncias superiores de governo e com vereadores, influência da mídia, entre outros. Nas escolas, a atuação de um diretor é frequentemente apontada como decisiva para a efetivação do acolhimento (OLIVA, 2010; RANDOLPHO; BURGOS, 2009), e a discussão aqui proposta é especialmente útil para instrumentalizar esses servidores públicos. 


\section{CAPÍTULO 2 - ACOLHIMENTO, ORGANIZAÇÃO E SEGURANÇA: DESAFIOS DA GESTÃO DOS CEUS}

No capítulo anterior analisamos projetos que orientaram a implementação dos CEUs em São Paulo. Propusemos uma discussão especialmente com aqueles que estiveram na origem da política pública em pauta, durante o mandato de Marta Suplicy (2001-2004). Mesmo tendo sido desenvolvidos em diferentes âmbitos por diferentes profissionais, esses projetos convergem no interesse em promover o acolhimento, na medida em que se preocupam em favorecer as comunidades do entorno urbano dos CEUs, ampliando seu poder de voz e recursos em geral.

Neste capítulo discutiremos problemas relacionados à concretização desses projetos. Para isso, lançaremos mão da discussão conceitual anteriormente realizada. Em poucas palavras, trabalharemos com uma distinção entre interações interpessoais, de um lado, e os contextos que dão suporte e influenciam essas interações, de outro. Com o termo contexto, fazemos referência a condicionantes das interações, que podem ser muito diversos (atuando no âmbito espacial, legal, temporal etc.), mas que agem conjuntamente sobre as interações. Para se relacionar, as pessoas precisam se haver com influências diversas, representadas por normas instituidoras de poder, características de espaço, desencontros de turnos de trabalho, entre inúmeras outras. Neste trabalho, propomos tratar essas influências como um conjunto.

Ainda em nossa discussão precedente, propusemos classificar os contextos em três tipos básicos. Os contextos extensivos maximizam as possibilidades de as pessoas escolherem interações. Os outros dois tipos de contexto condicionam mais fortemente as dinâmicas interacionais que se definem como não voluntárias: contextos intensivos obrigam as pessoas a se relacionar, tendendo a acelerar a política das interações cotidianas, enquanto contextos separadores introduzem interrupções ou intermitências nas interações, impedindo ou inibindo a sua efetivação. Cada um desses contextos oferece vantagens e desvantagens, de modo que nenhum deles pode ser visto como exclusivamente desejável ou indesejável. ${ }^{53}$

Inspirados neste modelo pretendemos, neste capítulo, iluminar desafios importantes para a promoção do acolhimento nos CEUs, a partir do estudo das práticas cotidianas em dois centros

\footnotetext{
${ }^{53}$ Vale lembrar mais uma vez que nesta pesquisa os termos contexto e âmbito designam coisas diferentes: o primeiro refere-se a fatores capazes de influir nas interações, e o segundo à natureza destes fatores. Assim podemos falar de contextos extensivos de âmbito espacial, contextos separadores de âmbito legal e assim por diante.
} 
educacionais dotados de características distintas e contrastantes. Como um dos CEUs construídos durante a gestão Marta Suplicy, o CEU Butantã esteve marcado pela atuação quase sempre veemente de partidários do acolhimento situados à esquerda do espectro político. $\mathrm{O}$ acolhimento veio associado à maximização de contextos extensivos, posteriormente rebatidos com a implementação de contextos separadores por parte de servidores que assumiram o poder em 2005. Como resultado, este CEU encontra-se permeado de afastamentos e animosidades interpessoais, em meio ao predomínio de extensividades e separações, dando conta de uma realidade que parece comum em outros centros educacionais. ${ }^{54} \mathrm{O}$ CEU Vila Rubi, de história mais recente, serve de contraponto ao primeiro e parece representar uma exceção quanto ao sucesso do acolhimento, tendo sido caracterizado por alguns de seus usuários e funcionários como uma espécie de "ilha" entre os CEUs da cidade. Nele, o acolhimento foi promovido de forma a angariar um maior número de adeptos e minimizar conflitos, articulando interesses e públicos que passam a interagir em meio a uma combinação mais integrada de contextos extensivos, intensivos e separadores.

Este capítulo dedica-se a analisar questões relacionadas à gestão dos CEUs. Como vimos no capítulo precedente, a gestão é a instância que articula os diversos equipamentos de um centro educacional (escolas, biblioteca, telecentro, entre outros). A gestão é também responsável pelos espaços e atividades não pertencentes a nenhum desses equipamentos em particular - áreas comuns de circulação e lazer, quadras de esporte, teatro, piscinas etc. Funcionários da gestão de um CEU possuem responsabilidades relativas ao atendimento de demandas internas e externas do CEU, à promoção de atividades e reuniões, à garantia da segurança, da manutenção e da limpeza, entre outras.

Como nosso interesse reside no problema do acolhimento, o foco da análise está na relação entre funcionários da gestão e usuários dos CEUs. Mesmo com este recorte preciso, será necessário levar em conta uma grande quantidade de práticas, tais como cursos, festas, eventos, práticas esportivas, reuniões e conselhos. A despeito das diferenças observadas entre os CEUs,

\footnotetext{
${ }^{54}$ A título de exemplo, cito o relato de artistas e produtores culturais durante uma reunião na Secretaria de Cultura, em 8 de abril de 2013, para planejamento do evento Estéticas das Periferias. Na ocasião, participantes observaram que havia só uns 10 CEUs na cidade "que funcionam", afirmando também que os CEUs "são um dos poucos espaços que se têm, mas estão totalmente distantes". A programação dos CEUs nos últimos anos teria privilegiado apresentações de grandes artistas sob o programa "CEU é Show", mas teria estabelecido pouco diálogo com a produção das comunidades locais. O gestor do CEU, naquela época, estaria "contra os critérios básicos da instituição", que é "entender e se relacionar com a comunidade onde está". Ainda que esses relatos provenham de um público específico de artistas e produtores culturais, é importante observar que são eles os frequentadores de CEUs que mais transitam pela cidade, em função da natureza de suas ocupações.
} 
um fator que os aproxima reside no fato de que a frequência à grande maioria das atividades organizadas por uma gestão é de caráter voluntário, ou seja, há neles um predomínio de contextos extensivos. Nesse sentido, as atividades promovidas contrastam fortemente com as que têm lugar nas escolas, já que neste caso a frequência dos alunos - e em certa medida dos educadores, vinculados que estão a uma progressão de carreira de longo prazo - é de caráter mais compulsório ou não voluntário, fazendo-se, em nossos termos, sob contextos intensivos. Isso traz consequências importantes para nossa análise, que só ficarão claras ao final do capítulo.

\subsection{CEU Butantã: extensividades versus separações}

No CEU Butantã, a dinâmica das interações cotidianas pode ser mais bem compreendida se apresentada cronologicamente. Servidores públicos dotados de intenções e valores antagônicos revezam-se na administração deste CEU ao longo de seus mais de dez anos de vida. Entre 2003 e 2004, funcionários à frente do CEU Butantã procuram o favorecimento das comunidades de seu entorno, franqueando acessos a diversas atividades, abrindo canais de diálogo entre funcionários e usuários, maximizando contextos extensivos (livre acesso, livre empréstimo de materiais, minimização de regulamentações etc.). Essa dinâmica entra em choque com preocupações com a segurança e a organização, que passam a predominar a partir de 2005, quando diversos contextos separadores (como grades, portões, regulamentações rígidas e proibições) são implementados.

Podemos afirmar de forma sintética que as preocupações com a segurança e a organização, de um lado, e com o acolhimento, de outro, são vistas como incompatíveis e mutuamente excludentes. No nível das interações, as incompatibilidades de valores e preocupações geram animosidades interpessoais. No nível dos contextos que servem de suporte a essas interações, dáse uma combinação de separações e extensividades: as primeiras impedindo que as pessoas tenham acesso umas às outras, as segundas garantindo-lhes a possibilidade de optar por encontros - que eram então evitados, na medida em que passaram a envolver indisposições mútuas. ${ }^{55}$

\footnotetext{
${ }^{55}$ No capítulo anterior observamos que a extensividade pode representar um fator de desincentivo ou desestímulo às interações, sobretudo quando há discórdias e animosidades interpessoais. No caso do CEU Butantã, o poder de
} 


\subsubsection{Extensividades espaciais}

No CEU Butantã, o âmbito que oferece maior extensividade é o espacial, graças às definições trazidas por um projeto padronizado de arquitetura que é comum aos 21 CEUs implementados pela gestão Marta Suplicy (2001-2004). Mas o tamanho excessivo do terreno do CEU Butantã - que é o segundo maior da cidade e conta com uma área equivalente a cinco quarteirões urbanos, ou cerca de 50 mil metros quadrados -, somado a outras características derivadas de sua situação urbana local, produzem um incremento significativo de extensividade, fazendo deste centro educacional um caso extremo em relação aos outros.

escolher encontros, garantido pelas características espaciais e legais que abordaremos a seguir, foi exercido no sentido de evitar esses encontros, às vezes completamente. 




Figura 24 - Foto aérea do CEU Butantã e entorno. Aglomerados "subnormais": 1-Favela do Sapê; 2-Castelinho; 3-Favela da Água Podre; 4-Favela São Domingos ("Rua Oito"); 5-Rio Pequeno; 6-Jardim das Vertentes; 7-Jardim Jaqueline; 8-Mandioquinha. ${ }^{56}$

\footnotetext{
${ }^{56}$ As comunidades comumente mencionadas no cotidiano do CEU Butantã não coincidem exatamente com os aglomerados urbanos subnormais oficialmente reconhecidos pela Assessoria Técnica de Planejamento e Pesquisa da Secretaria Municipal de Habitação - conforme constam no site www.habisp.inf.br (acessado em setembro de 2014). A Comunidade São Domingos também parece ser designada por Comunidade da Rua Oito, e possui um perímetro mais amplo do que o estabelecido oficialmente, tornando-a imediatamente vizinha ao CEU. Na foto aérea, preferi indicar este perímetro ampliado. Além desta designação, ouvi outros nomes de comunidades que não coincidem com os dados oficiais: Polop, Mil e Dez, Lixão, Prainha, entre outros.
} 
O CEU Butantã localiza-se nas proximidades do quilômetro 15 da Rodovia Raposo Tavares, a meio caminho entre a Marginal Pinheiros e o Rodoanel, na zona oeste. Se esta é a zona com melhores indicadores socioeconômicos da cidade, o entorno do CEU situa-se nas proximidades de uma concentração importante de favelas ou aglomerados urbanos "subnormais" 57 . Desta forma, existem disparidades socioeconômicas e urbanas significativas em seus arredores, fato que contribui para uma ocupação desigual também dos espaços internos do CEU. Grosso modo, podemos pensar numa divisão norte-sul tanto para o entorno urbano imediato do centro educacional quanto para suas áreas internas. As próprias práticas e discursos dos frequentadores relacionam-se com essa divisão, ainda que ela raramente seja reconhecida de modo explícito.

\footnotetext{
${ }^{57}$ Nomenclatura usada oficialmente pelo IBGE (Instituto Brasileiro de Geografia e Estatística).
} 

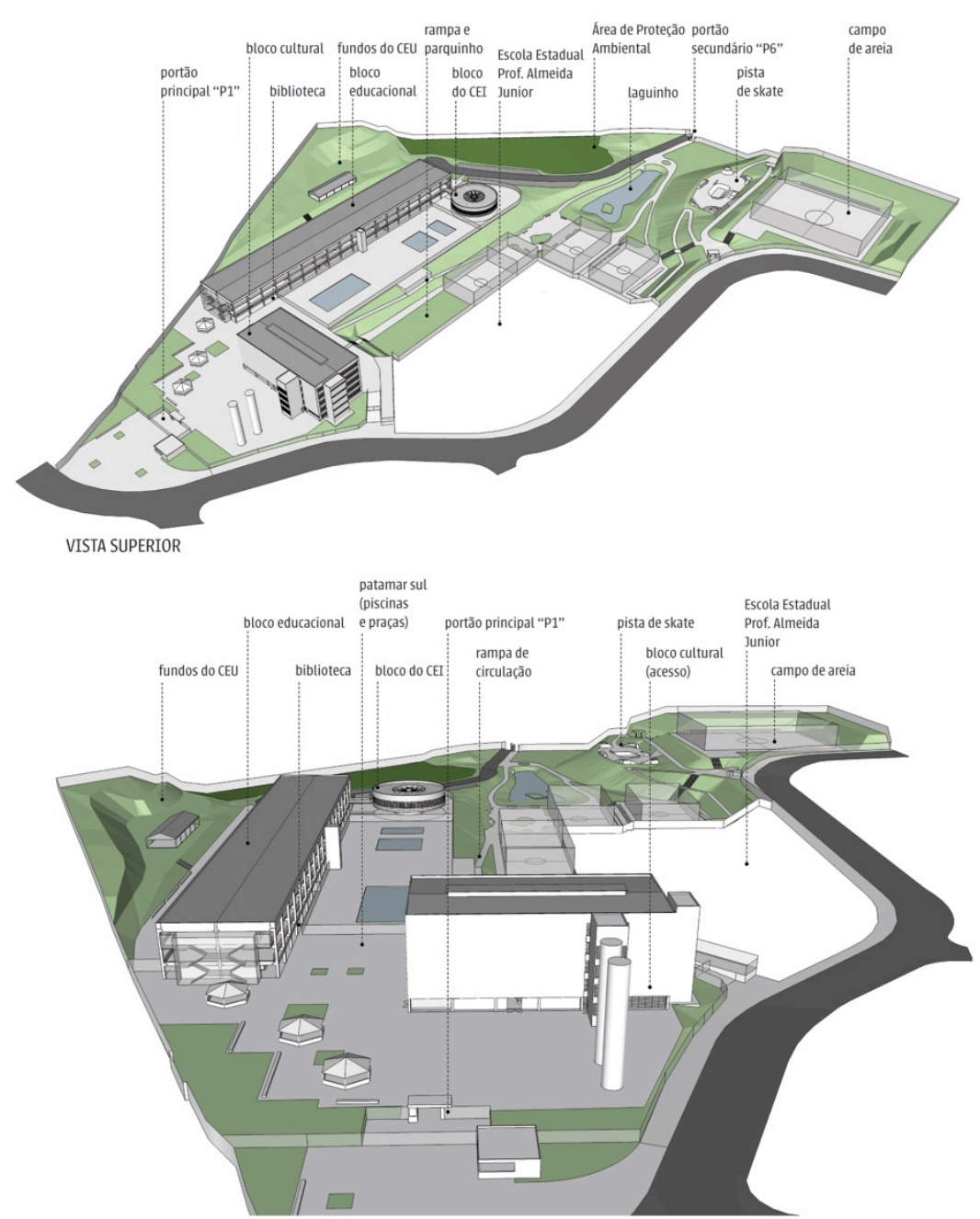

VISTA DO PORTÃo PRINCIPAL “P1" E DO PATAMAR SUL

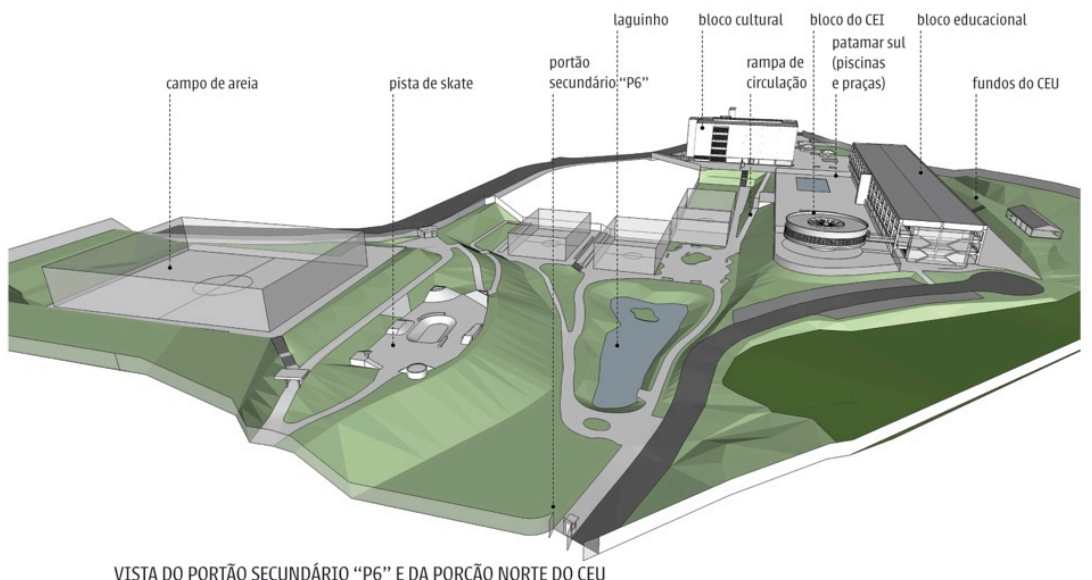

Figura 25 - Perspectivas do CEU Butantã. 


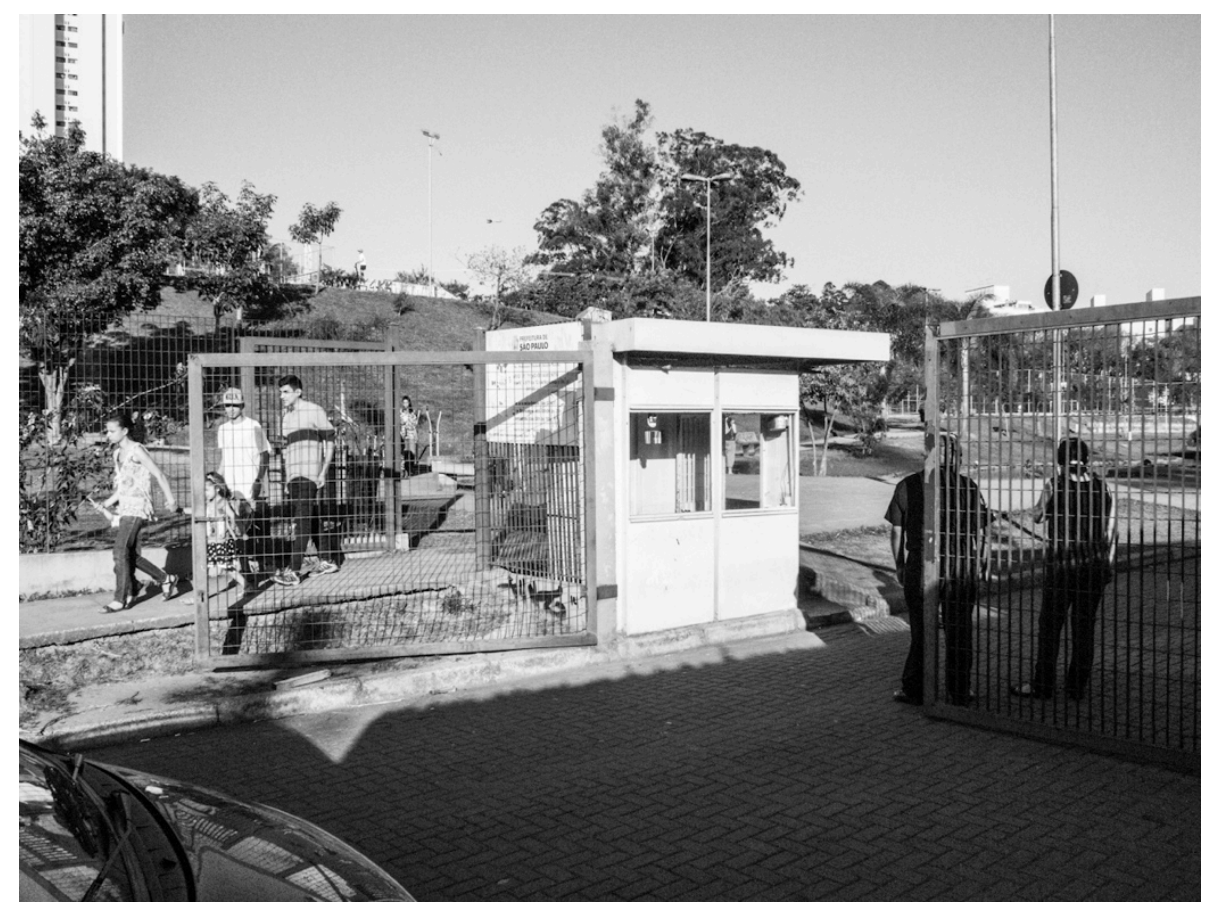

Figura 26 - Portão de acesso secundário ao CEU, conhecido como "P6". Ao fundo podemos ver a encosta encimada pela pista de skate.

A maior parte das comunidades de menor renda situa-se ao norte do CEU, inclusive a vizinha São Domingos, por vezes chamada de Rua Oito. Através do portão secundário conhecido como "P6", os públicos oriundos dessas comunidades alcançam o interior do centro educacional e ocupam predominantemente as áreas mais ao norte. Ali se concentram os espaços de lazer e esportes, com destaque para quatro quadras poliesportivas, uma praça com bancos vizinha a um pequeno lago artificial, além de uma pista de skate e uma quadra com piso de areia, situados em patamares de uma encosta bastante íngreme. Facilmente acessível pelas comunidades e distante dos equipamentos e edifícios do $\mathrm{CEU}$, esta área norte abriga uma quantidade regular de frequentadores em práticas cotidianas pouco pautadas por representantes da gestão e por regulamentos institucionais. Predominam os códigos de sociabilidade dos moradores mais pobres, sobretudo dos jovens, em interações variadas, construídas em torno de jogos de bola, manobras de skate, paqueras, passeios, brigas, discussões e conversas. 


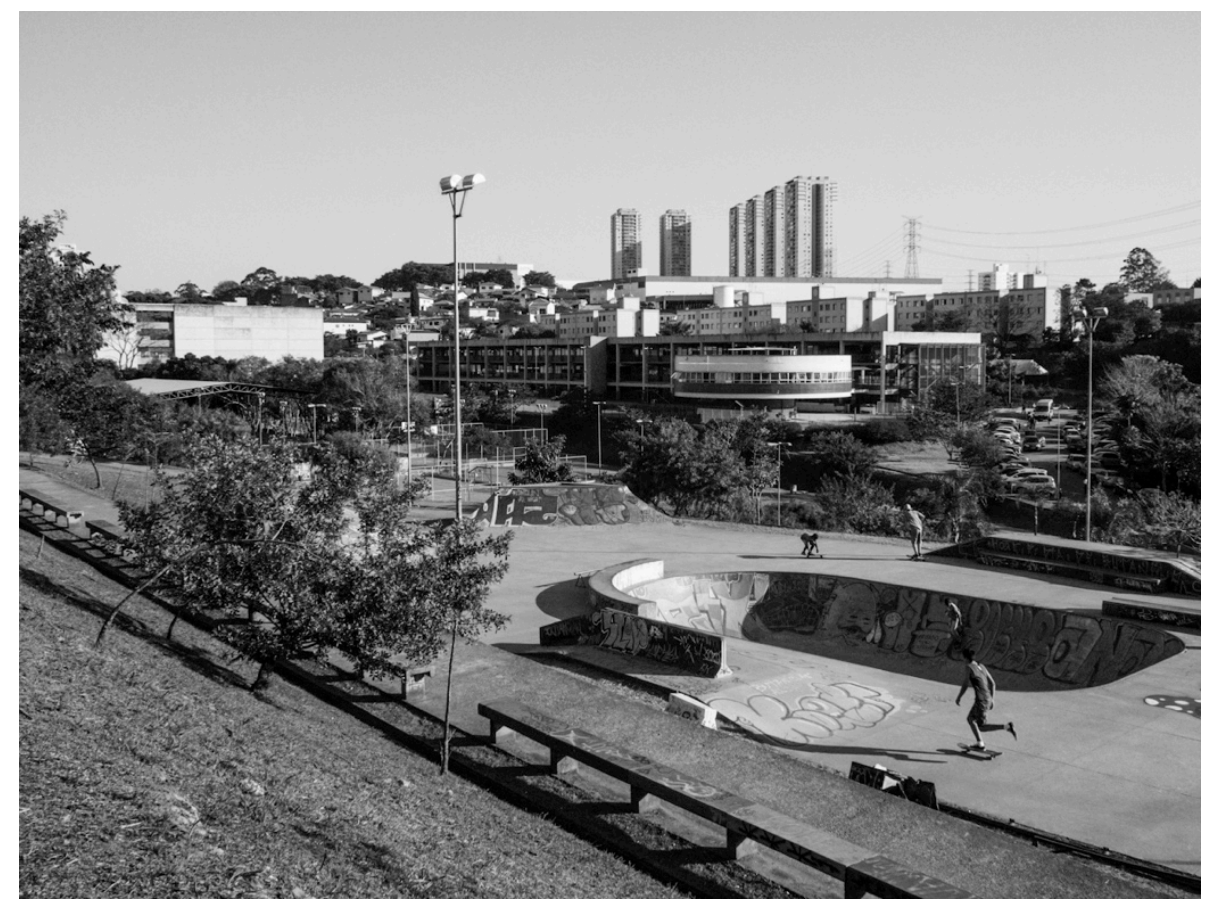

Figura 27 - Vista da encosta na porção norte do CEU Butantã, com pista de skate em primeiro plano, e edifícios do CEU ao fundo.



Figura 28 - Lago e caminho principal da porção norte do CEU Butantã.

Toda essa área articula-se com a porção sul do centro educacional por meio de uma extensa rampa de circulação, ladeada pelo talude e pelas grades da área da piscina, de um lado, e por um 
parquinho infantil quase desprovido de brinquedos e muito pouco frequentado, de outro. Ao transpormos essa rampa, sua conotação naturalmente mais associável ao ato de deslocar-se é reforçada pela rarefação de atividades à volta, de modo que nos sentimos atravessando uma espécie de intervalo espacial e temporal que reforça a divisão do CEU em duas áreas distintas.

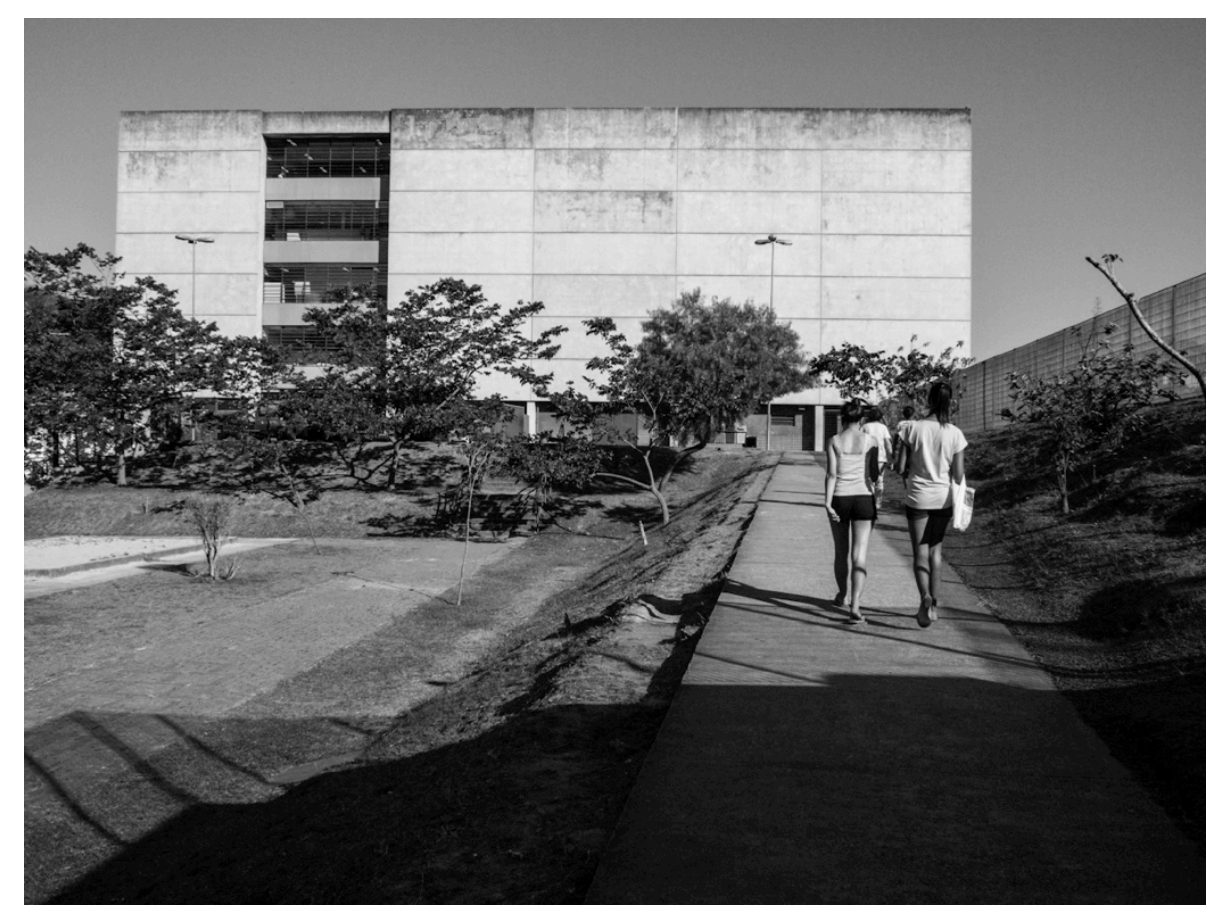

Figura 29 - Rampa de interligação das porções norte e sul do CEU Butantã, com parquinho à esquerda, grades à direita e bloco cultural ao fundo.

A rampa nos leva a um patamar grande e plano que configura a porção sul do terreno do CEU. Nesta área localiza-se o "P1", que em termos formais configura-se como a entrada mais importante, dotada de guarita e marquise. O P1 está mais próximo a bairros residenciais de médio poder aquisitivo e à Avenida Engenheiro Heitor Eiras Garcia, eixo de acessibilidade regional que conduz à Rodovia Raposo Tavares e ao resto da cidade. Desta forma o P1 associase, com o patamar sul do centro educacional, à identidade de públicos oriundos de áreas mais ricas ou afastadas do CEU. Além disso, o patamar sul abriga todos os equipamentos do CEU, e nesse sentido sua identidade aproxima-se daquela de uma instituição pública, dotada de normas e funcionários.

O patamar sul associa-se à identidade institucional não apenas porque abriga todas as edificações e equipamentos do CEU, mas também porque suas áreas livres configuram-se como 
praças quase sempre vazias, não sendo coloridas por usuários ou atividades específicas, como vimos acontecer na porção norte do CEU. As praças são ocupadas em eventos culturais e educacionais, mas na maior parte do tempo transmitem uma ideia de não lugar, de lugar de passagem, sendo utilizadas apenas para a circulação de pessoas e para interações efêmeras em encontros fortuitos. Assim entendidas, as praças são vazios concebidos em relação aos cheios das edificações, e terminam por reforçar a importância dos edifícios e da identidade institucional do patamar sul.

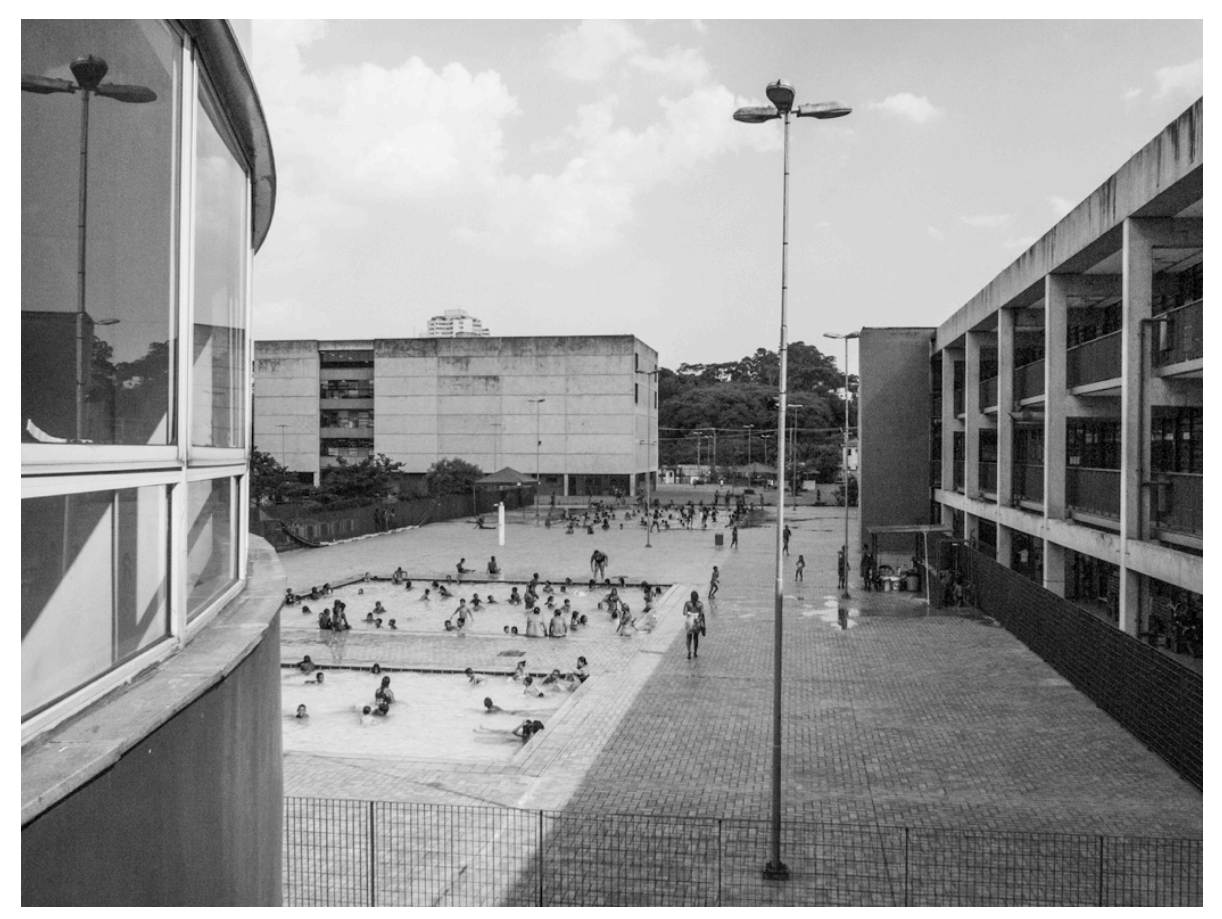

Figura 30 - Vista do CEI em direção às praças de circulação (depois da área das piscinas) e aos outros edifícios do patamar sul do CEU Butantã: à direita da imagem, o bloco pedagógico; ao fundo, o bloco cultural.

Fica claro que a divisão norte-sul do CEU organiza um conjunto de outras oposições: ao norte concentram-se as atividades ao ar livre, o lazer e os frequentadores mais pobres, além de estarem ausentes normas institucionais; no sul encontram-se as atividades educacionais e culturais e os frequentadores de maior poder aquisitivo, além de haver uma maior sujeição a funcionários e regulamentos. No decorrer desta exposição, deslindaremos uma simbiose pressuposta nessa descrição inicial, que associa, indistintamente, intencionalidades e contextos. Por um lado, há um desinteresse recíproco em buscar compartilhamentos de espaços e atividades entre os públicos mencionados. Por outro, há uma série de características espaciais que garantem 
a esses públicos a escolha da não interação: acessos distintos (P1 e P6) permitem evitar encontros; espaços muito amplos produzem um espalhamento que minimiza pontos de contato; a comunicação entre as porções norte e sul do CEU acontece através de um gargalo em rampa; atividades afins concentram-se em áreas distintas.

Se nos ativermos aos limites do patamar sul, veremos que há distâncias consideráveis também entre seus edifícios, equipamentos e atividades. Conforme vimos no capítulo anterior, uma poética de arquitetura pautada pela clareza e concisão decidiu agrupar os vários equipamentos do CEU em uma quantidade reduzida de grandes volumes edificados. Em primeiro lugar, há o bloco cultural, reunindo teatro, ginásio, salas para cursos e escritórios da gestão. Este bloco impõe distâncias grandes àqueles interessados em adentrá-lo, ao mesmo tempo que concentra os programas disponíveis ao público em geral: é fechado e opaco ao exterior; ${ }^{58}$ possui um acesso pouco evidente, distante e marginal em relação ao patamar sul; organiza seu programa em altura, de modo que seus frequentadores são obrigados a subir até quatro lances de escada ou a aguardar o tempo do elevador. ${ }^{59}$

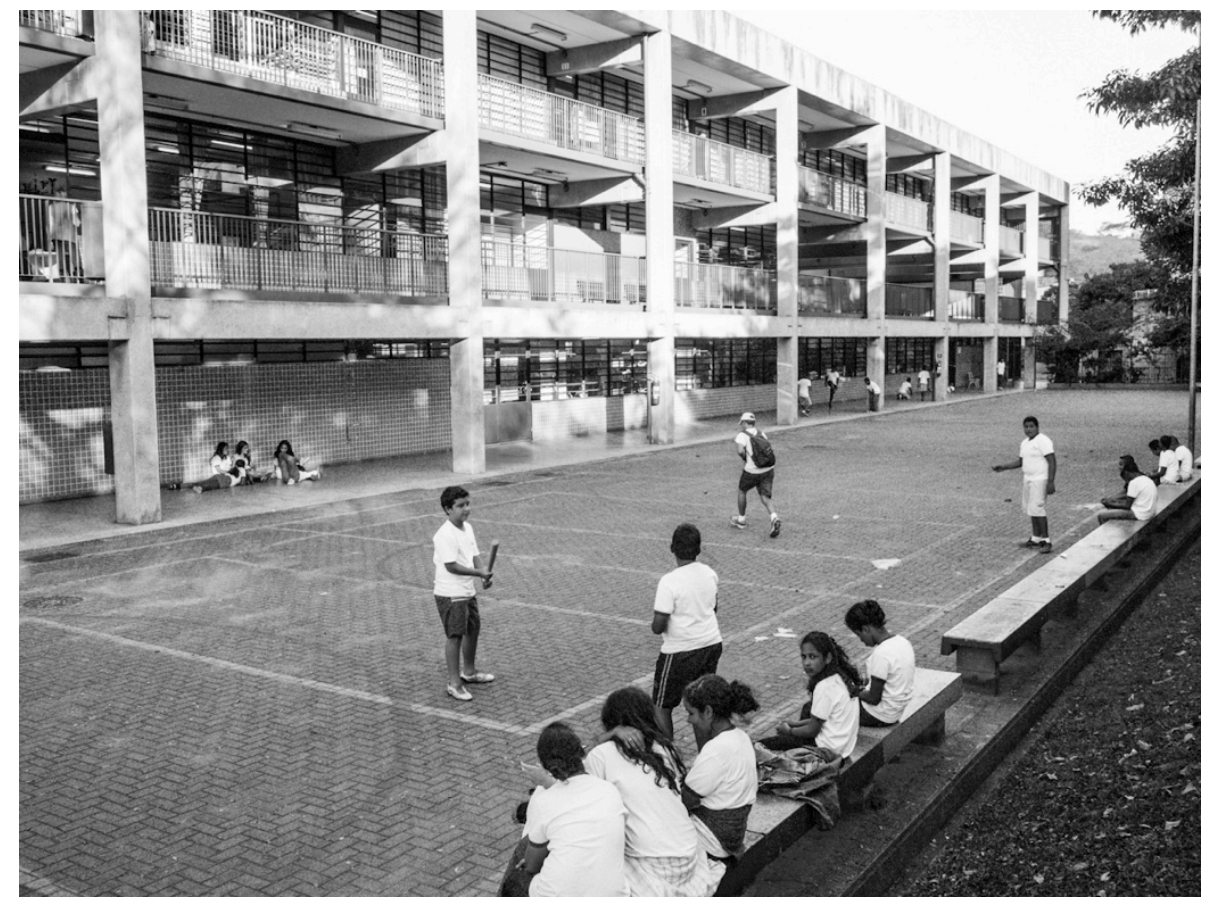

\footnotetext{
${ }^{58}$ No capítulo anterior acompanhamos uma discussão que terminou com a escolha do modelo "italiano" para o palco dos primeiros CEUs, à revelia das intenções originais dos autores do projeto arquitetônico. Essa mudança trouxe a necessidade de separar os espaços internos e externos do teatro, e produziu a configuração hermética que observamos atualmente para o bloco cultural dos primeiros CEUs.

${ }^{59}$ Acrescente-se que a presença de vias de circulação concorrentes (escada e elevador) é motivo para desencontros. Diga-se de passagem, os escritórios da gestão estão no terceiro piso deste bloco. Os espaços internos do bloco cultural estão representados na figura 6 , no primeiro capítulo.
} 
Figura 31 - Vista dos fundos do bloco educacional do CEU Butantã.

Em segundo lugar, há o bloco pedagógico, abrigando, entre outros equipamentos, a biblioteca, o telecentro, a padaria-escola e todas as escolas do CEU (CEI, EMEI, EMEF, sendo que o espaço desta última é utilizado à noite pela EJA e pela ETEC). Neste caso o programa arquitetônico foi organizado num volume extenso, longilíneo, vazado em toda a sua volta e rodeado por corredores de circulação e superfícies envidraçadas, deixando expostos lugares que, no entanto, dedicam-se predominantemente a públicos mais específicos do que os do bloco cultural. ${ }^{60}$ Além disso, os acessos a esses equipamentos tampouco são evidentes ou próximos uns dos outros. Se há uma quantidade menor de andares, há maiores distâncias horizontais a percorrer, de modo que o espaço não oferece incentivo às interações. Finalmente, como um anexo desse bloco educacional, encontra-se o pequeno volume circular dotado de balanços perimetrais que abriga parte das salas de aula do CEI, contribuindo para a dispersão dos espaços dentro desse equipamento. ${ }^{61}$

Observamos que, em menor escala, a disposição de equipamentos, edifícios e atividades no patamar sul confirma o predomínio de contextos extensivos para o CEU em sua totalidade: diversas características espaciais configuram extensividades que aumentam a quantidade de encontros facultativos e minimizam os encontros compulsórios entre funcionários, e entre funcionários e usuários. Por vezes as distâncias e dificuldades de acessar os lugares são tão grandes que passam a representar contextos separadores, de modo que certas interações já não são mais uma opção. Isso apenas reforça o diagnóstico geral de rarefação de encontros. ${ }^{62}$

\subsubsection{Acolhimento (2003-2004)}

As características espaciais acima indicadas somam-se a outros fatores que fornecem suas próprias parcelas de extensividades e separações. Durante a gestão Marta Suplicy os âmbitos

\footnotetext{
${ }^{60} \mathrm{O}$ projeto original de arquitetura previa uma importância maior a esses corredores de circulação, que recebiam públicos diversos. Modificações posteriores incentivaram o isolamento entre públicos escolares e outros.

${ }^{61} \mathrm{O}$ bloco pedagógico e o volume circular do CEI podem ser observados nas figuras 4 e 9, no primeiro capítulo.

${ }^{62}$ Além das distâncias excessivas, a dificuldade de encontrar as entradas dos equipamentos é outra consequência do projeto de arquitetura, que termina por produzir contextos separadores. Nesse sentido, as separações são mais fortes para usuários recém-chegados, que não conhecem a localização dos acessos. Muitos usuários têm dificuldade de encontrar a entrada da biblioteca, por exemplo, conforme diversos relatos da coordenadora desse equipamento. Confusões também derivam do fato de que equipamentos muito diferentes estão agrupados sob um mesmo volume edificado: certas pessoas pensam que a biblioteca do CEU é dedicada exclusivamente às escolas, quando na verdade destina-se também ao público em geral. Outro exemplo refere-se à dificuldade de alguns pais de alunos em distinguir uma e outra escola, conforme depoimento de uma coordenadora pedagógica da EMEI. Dificuldades semelhantes foram relatadas em Souza (2010, p. 149).
} 
político e educacional dos CEUs atuaram em prol da extensividade de modo análogo ao que vimos para o espaço. Isso ocorreu tanto na forma de atividades, canais de participação ampliados, minimização de normas e burocracias de utilização, como por meio de um regimento interno que previu poucas relações hierárquicas e muitos vínculos horizontais e facultativos entre pessoas e equipamentos. Tais fatores, no entanto, sofreram modificações muito maiores do que aquelas observadas nos espaços, já que em muitos sentidos estes últimos costumam exigir uma quantidade maior de esforços e recursos para serem transformados. Para termos uma ideia de como a extensividade pautou o âmbito político e educacional dos CEUs durante a gestão Marta Suplicy, precisamos recorrer a depoimentos e registros históricos.

Relatos de antigos usuários e funcionários do CEU Butantã são praticamente unânimes em reconhecer a enorme quantidade de atividades e o grande público recebido no período que vai de setembro de 2003, quando o centro educacional foi inaugurado, e o início de 2005, quando termina o mandato de Marta Suplicy. Fernanda Alvez, moradora local, relata que as piscinas eram franqueadas à livre utilização e viviam lotadas aos finais de semana; o teatro exibia filmes infantis e apresentações artísticas; e mesmo a biblioteca "vivia cheia". ${ }^{63}$ A educadora Anna Cecília Simões, que foi a gestora do CEU na maior parte do período considerado, ${ }^{64}$ destaca: a padaria-escola oferecia cursos de panificação e confeitaria organizados pelo famoso padeiro Olivier Anquier; havia cursos de diversos instrumentos musicais, muitos deles importados graças a um patrocínio do Grupo Pão de Açúcar; exposições de arte tinham lugar regularmente no foyer do teatro do CEU. Evandro, outro morador antigo do entorno do CEU, ${ }^{65}$ salienta a grande procura por atividades esportivas, lembrando que o ginásio e as quadras de esporte eram intensamente utilizados - segundo ele, mesmo o campo de areia, que na época possuía refletores, funcionava até tarde da noite. Grupos de moradores organizavam-se em times e realizavam disputas semanais, e professores voluntários, também moradores das comunidades, ofereciam

\footnotetext{
${ }^{63}$ Conforme entrevista concedida a mim em 17/07/2012. Fernanda é uma liderança política local e mora nas imediações ao norte do CEU desde antes do início de sua construção. Foi vice-presidente do Conselho Gestor há alguns anos, e participou ativamente de reuniões de pais do CEI e EMEI durante a década passada, quando seu filho era aluno desses equipamentos. Seus relatos aparecerão diversas vezes ao longo deste capítulo.

${ }^{64}$ Anna Cecília Koebcke de Magalhães Couto Simões - que conhecemos no capítulo anterior - foi gestora do CEU Butantã entre dezembro de 2003 e março de 2005. Possui uma longa e notável trajetória como educadora engajada na promoção de práticas educativas em escolas públicas de regiões carentes do Rio de Janeiro e São Paulo. A educadora concedeu-me entrevistas em 02/05/2013, 23/05/2013, 06/06/2013 e 19/07/2013.

${ }^{65}$ Fui apresentado a Evandro (nome fictício) na festa junina de 09/06/2013, por um ex-funcionário do CEU, como alguém ligado ao Primeiro Comando da Capital (PCC), organização que estaria relacionada ao tráfico de drogas mas também à regulação da atividade criminosa em áreas periféricas da cidade. Nestes locais, a legitimidade do PCC pode chegar a rivalizar com a do próprio Estado, representado pela polícia (FELTRAN, 2011).
} 
aulas de futebol a jovens interessados.

As atividades eram oferecidas dentro de uma proposta de "acesso sem nenhum impedimento" 66 , confiando no poder do diálogo entre funcionários e usuários para a construção de um convívio voluntário em meio a contextos extensivos. Mas sob certo ponto de vista, as interações podem ser consideradas como parcialmente induzidas, porque estavam implicadas na consecução de atividades que eram do interesse das pessoas - nesse sentido, aproximam-se de nossa definição de intensividade. No capítulo anterior definimos contexto intensivo como aquele em que as interações interpessoais são forçadas e involuntárias; mas elas podem ser involuntárias tanto ao ir declaradamente contra as intenções das pessoas quanto ao envolver coisas de seu interesse que, para serem acessadas, exigem interação. Esta combinação entre intensividade e extensividade parece ter sido muito importante para a promoção do acolhimento nos primeiros anos de história deste centro educacional. Outras intensividades mais perenes referem-se à frequência obrigatória de alunos às escolas e às relações de trabalho em geral - falaremos mais sobre elas nos tópicos finais desta seção.

A ampliação de canais de participação política também representou um incremento na extensividade. As exposições, festas e eventos seguiam eixos temáticos que se revezavam a cada mês, de acordo com um projeto pedagógico coordenado pela gestão, com participação dos outros equipamentos do centro educacional. Por exemplo, em setembro de 2004, quando as atividades do CEU orientaram-se pelo tema da independência do Brasil, a coordenadora da biblioteca, Regina Ferreira, teve liberdade para propor à gestão a realização de uma exposição sobre a emancipação feminina de uma mulher negra. Para isso, alegou que o assunto relacionava-se ao fato histórico em questão. ${ }^{67}$ Os canais de diálogo existiam não apenas entre funcionários e equipamentos do $\mathrm{CEU}$ : conselhos compostos por usuários e funcionários foram implementados para discutir assuntos específicos, com destaque para o conselho gestor das quadras do CEU, voltado para a definição de regras de compartilhamento e funcionamento dos espaços esportivos. $^{68}$

\footnotetext{
${ }^{66}$ Conforme a expressão empregada pela bibliotecária Regina Ferreira em conversa de 05/04/2013, para interpretar o estilo de gestão exercido por Anna Cecília Simões.

${ }^{67}$ Conforme depoimento da bibliotecária Regina Ferreira em 19/05/2011.

68 "Todos queriam usufruir de tudo ao mesmo tempo, mas era preciso que a comunidade encontrasse a forma de se organizar sem que essa organização fosse imposta." Excerto do livro Educação, CEU e Cidade (DORIA, 2007, p. 209), baseado no depoimento de Maria da Penha Silva, moradora das imediações do CEU e coordenadora do Núcleo de Ação Cultural em 2004. Este conselho também indica a criação de uma combinação de contexto extensivo e intensivo, na medida em que se dedica a deliberar sobre assuntos de grande interesse dos participantes - veremos
} 
Observemos que, mesmo para certos funcionários atuantes nos primeiros anos do CEU, o estilo de gestão de Anna Cecília Simões trazia riscos preocupantes, por ser predominantemente amparado na construção de pactos voluntários e dialogados. Por exemplo, uma antiga funcionária avaliou que, com as escolas todas "abertas", não havia um controle efetivo das crianças; quando uma professora levava alunos até o parquinho do CEU, "perdia meia dúzia pelo caminho"; e "na piscina, entrava quem queria", sem a exigência efetiva de cadastros e trajes de banho apropriados. ${ }^{69} \mathrm{Com}$ isso fica evidente que o maior poder de escolha, constitutivo de contextos extensivos, traz também a probabilidade de usos inoportunos ou prejudiciais desse poder. Quando há liberdade para agir e interagir, é de esperar que ela seja usada, ao menos por alguns, num sentido indesejado por outros, até mesmo subtraindo-lhes sua própria parcela de liberdade. $^{70}$

Os exemplos mostram uma relação clara entre liberdade e incerteza. Num centro educacional de espaços abertos, pleno de atividades capazes de atrair o público e gerido com a participação de usuários - ou seja, num CEU dominado pela extensividade - podemos imaginar que a parcela de incerteza era bastante expressiva. Comprometidos com o acolhimento, os primeiros gestores deste centro educacional assumiam este risco como necessário e inerente ao acolhimento, ou seja, à promoção de direitos, recursos e canais de participação. ${ }^{71}$ Os novos gestores, no entanto, encararam a liberdade como permissividade, e a consequente incerteza como sujeição a riscos, falta de segurança e desorganização.

\subsubsection{Organização e segurança (2005-2012)}

Durante os mandatos de José Serra (2005-2006) e Gilberto Kassab (2006-2012), a gestão do CEU Butantã passou a orientar-se por um estilo de administração muito diferente do que

coisa semelhante acontecer no CEU Vila Rubi. O livro de Doria também se refere a um conselho das escolas do entorno e aos conselhos internos de cada escola do CEU Butantã.

${ }^{69}$ Conforme conversa que travei com a funcionária em 17/07/2012.

${ }^{70}$ Uma situação ilustrativa disso, ainda que um tanto caricata, foi um debate entre servidores sobre qual atitude tomar em relação a um jovem que entrara armado numa festa da EMEF. A gestora Anna Cecília Simões criticara a hipótese de chamar a polícia, defendendo a importância de um convencimento verbal do jovem em declinar de sua arma. Conforme relato da bibliotecária Regina Ferreira, de 05/04/2013. A procura de acordos voluntários como este é característica de contextos extensivos.

${ }^{71}$ Por exemplo, Anna Cecília Simões refere-se a uma discussão entre uma avó e seu neto, aluno de uma escola do CEU, que recusava-se insistentemente a descer de uma árvore em que subira. Já impaciente, a avó teria lhe dito: "Menino, desce daí, se não você vai morrer!". A resposta do menino, apreciada pela educadora, foi: "mas vó, se eu descer eu já morri!". Com isso, enfatiza-se a necessidade de assumir a incerteza trazida com a ampliação da liberdade. Conforme depoimento prestado a mim por Anna Cecília Simões em julho de 2013. 
vimos até o momento. ${ }^{72}$ Um relato da educadora Déborah Valverde, que passou a coordenar o Núcleo de Ação Cultural da gestão durante os oito anos considerados, é ilustrativo dessas mudanças. Uma semana antes de assumir suas atribuições, ao comparecer ao CEU e assistir a uma peça de teatro infantil, a educadora sentiu-se "escandalizada" com o comportamento das crianças. Ao término da peça e sem que fossem impedidas por ninguém, as crianças subiram no palco, danificaram cenários e penduraram-se nas cortinas, recusando-se a parar quando ela própria tomou a iniciativa de contê-las. Este acontecimento motivou-a a desenvolver um trabalho de "formação de público" destinado a ensinar regras de comportamento para apresentações culturais aos alunos do $\mathrm{CEU} .^{73}$ Assinala-se, com isto, a proliferação de formas de regulação da conduta envolvendo contextos separadores, que a partir de então passaram a presidir as interações interpessoais no centro educacional.

Fica claro que a radicalização da extensividade contribuiu para produzir seus próprios opositores, multiplicando motivos para uma veemente reação. Mas não é apenas como reação que a atuação dos novos gestores deve ser compreendida, na medida em que eles pautavam-se por seus próprios valores e práticas. ${ }^{74}$ Contextos separadores passaram a ser implementados para garantir a segurança e a organização, sendo secundariamente - e de modo muito pouco convincente para a população - associados à qualidade do atendimento e ao benefício dos usuários em geral. A isto associava-se ainda um reforço de hierarquias de poder, uma ativação pouco frequente de canais de participação e diálogo e, muitas vezes, a atribuição de estigmatizações ou identidades culturais rígidas aos moradores das comunidades. Assim constituídos, contextos e intencionalidades associavam-se e ainda reforçavam uma redução de recursos e canais de participação iniciada em instâncias superiores do governo municipal. ${ }^{75}$

Antes de mais nada, as separações constituíram-se pela proliferação de normas e critérios

\footnotetext{
${ }^{72}$ Revezaram à frente da gestão as educadoras Elisabete Gaspar Tunala (2005-2006), Elisabete Lauande (20062010) e Eliane dos Santos Luscri (2010-2012). A primeira substituição foi motivada por motivos de saúde e a segunda por aposentadoria, fatos que não indicam diferenças de posicionamentos políticos e reforçam a ideia de continuidade de estilo de gestão.

${ }^{73}$ De acordo com depoimento concedido a mim em agosto de 2010.

${ }^{74}$ As diferenças de pontos de vista também foram colocadas pelos novos gestores em termos de uma contraposição entre realismo e idealismo. No depoimento já citado de Déborah Valverde, a educadora avaliou que o estilo de gestão que a precedeu, inspirado no ideário freiriano, "é muito bonito, mas tudo no papel". No mesmo sentido vai a resposta que a nova gestora Elisabete Gaspar Tunala deu à bibliotecária Regina Ferreira, quando esta lhe perguntou, em 2005, qual seria a sua "concepção pedagógica" para o CEU. A gestora teria lhe dito: "vocês aqui falam muito de concepção; eu quero ver trabalho". Conforme depoimento da bibliotecária em 19/05/2011.

${ }^{75}$ Conforme discutido no capítulo anterior. Por exemplo, a gestão de José Serra publicou um regimento novo para os CEUs (SÃO PAULO, 2006), em que retirou a elegibilidade dos gestores e diminuiu poderes do conselho gestor.
} 
de funcionamento. Por exemplo, um membro de um time de futebol que frequentava semanalmente as quadras nos primeiros anos do CEU lembra-se da irritação sentida por todos quando descobriram que os agendamentos para uso dos espaços esportivos passaram a ser realizados sem consulta aos frequentadores habituais, em contraste com o processo decisório anterior, realizado pelo conselho participativo das quadras. Uma praticante assídua de vôlei conta ter se afastado do CEU quando foram proibidos empréstimos de rede e de bolas para a prática do esporte. ${ }^{76}$ Uma professora de EMEI avaliou que no CEU "tudo é uma briga, tudo é uma luta", ao referir-se, com certa indignação, à necessidade de "pré-agendar" a apresentação de seus alunos no teatro, deixando claro haver uma diferença entre isso e o agendamento efetivo. ${ }^{77}$ Em mais de uma ocasião presenciei educadores da EMEF queixando-se da dificuldade que tinham para conseguir que seus alunos utilizassem os espaços administrados pela gestão. "Ninguém conseguia autorização", disse um deles, sobretudo com relação à utilização das piscinas - que encontrei vazias em quase todas as minhas visitas de campo - e do ginásio de esportes e da sala de dança - ambos dotados de um piso de madeira que, conforme alegavam os gestores, demandava cuidados especiais e restrições de utilização.

Em segundo lugar, contextos separadores foram implementados através da simples indisponibilização de espaços e recursos, diminuindo as possibilidades de interações interpessoais. Por exemplo, a quadra de areia e a padaria-escola estiveram fechadas ou sem condições de utilização, e instrumentos musicais foram mantidos trancados em armários por muitos anos. ${ }^{78} \mathrm{~A}$ abertura espacial definida pelo projeto arquitetônico continuou assegurando a possibilidade do livre trânsito, mas mesmo ela chegou a ser ameaçada numa iniciativa da gestão, em 2011, para implantar controles de acesso na forma de carteirinhas. Em 29/04/2011, os gestores convocaram uma plenária para discutir a implantação das carteirinhas, justificando-as com um conjunto de problemas relacionados à segurança: duas perseguições policiais a assaltantes refugiados no interior do $\mathrm{CEU}$, atos de vandalismo e depredação, conflitos com usuários da pista de skate. A gestora pôs em xeque sua própria segurança, ao considerar que a

\footnotetext{
${ }^{76}$ Depoimentos colhidos entre frequentadores da festa junina de 09/06/2013.

${ }^{77}$ De acordo com conversa que travei com ela, na festa de aniversário de sete anos do CEU, em 11/09/2010.

${ }^{78}$ De acordo com alguns relatos de antigos usuários, a indisponibilização de espaços também pode ser relacionada a transferências compulsórias de alunos que passaram a ocorrer nas escolas da rede municipal. Com isso, alunos moradores das comunidades do entorno dos CEUs deixaram de frequentá-lo, sendo substituídos por crianças provenientes de bairros mais distantes. O depoimento de um pai fala que protestos das famílias do entorno foram respondidos com justificativas a seu ver burocráticas, pois tributavam a responsabilidade da realocação a instâncias superiores de governo. A transferência compulsória constituiu-se assim como um contexto separador não apenas dos alunos, mas também de suas famílias, que teriam deixado de frequentar o CEU.
} 
diretora da escola vitimada pela então recente tragédia do Realengo havia sido responsabilizada pelo ocorrido:79 "Eu não quero, então, amanhã ou depois, ouvir falar que a gestora não pensou, que ela deixava todo mundo entrar, que ela nunca se preocupou com a comunidade, que ela nunca, assim, deu uma ideia, uma sugestão de segurança. A gente está, isso tudo está registrado." Vemos que os receios para com a segurança do CEU e para com a própria segurança aparecem associados na fala da gestora.

Além de referir-se à segurança, a gestora investiu na possibilidade de modificar o sentido atribuído às carteirinhas, afastando-as da noção de "exclusão" e aproximando-as da de "organização":

Aí alguém colocou [...] mas e para aquela pessoa que quer visitar o CEU, quer dizer que agora o CEU vai ficar fechado? Só vai entrar quem tem carteirinha? Não! E a carteirinha, gente, é uma ideia de organização, não de exclusão. Todo mundo vai continuar frequentando o CEU, só que a gente quer que mostre uma carteirinha.

A maioria dos participantes da plenária era composta por pais de alunos favoráveis aos controles de acesso. Porém, a fala da líder comunitária e vice-presidente do conselho gestor, Fernanda Alvez, ia contra a proposta da gestora e sugeria um modo como as carteirinhas seriam vistas por grupos que não estavam presentes na plenária:

A forma de resolver o problema de segurança não é pondo carteirinha e impedindo as pessoas de entrar, né, porque acaba sendo isso sim, porque na prática não é do jeito que é falado na teoria. Entendeu? [...] vocês podem ir em CEUs que têm carteirinha que não é assim. O acesso não é livre dessa forma.

As carteirinhas não foram efetivadas, em parte certamente por se inserirem num processo mais amplo e progressivo de implementação de separações que efetivamente produziram afastamentos - a despeito da tentativa de ressignificar o assunto, contida na fala supramencionada da gestora. ${ }^{80}$

Além das normas de funcionamento e da indisponibilização de espaços, separações foram

\footnotetext{
${ }^{79}$ A tragédia do Realengo foi um assassinato em massa ocorrido em 07/04/2011 numa escola municipal do bairro homônimo, no Rio de Janeiro, causando grande repercussão nacional.

${ }^{80}$ No CEU Vila Rubi, observaremos uma mesma oscilação de significados atribuíveis a controles de acesso. Naquele centro educacional, no entanto, havia um conjunto de ações que tornou mais plausível a dissociação entre controle de acesso e a ideia de exclusão. Isso mostra que os significados construídos em torno dos contextos pode ser decisivo para a determinação de seus efeitos.
} 
implementadas com a redução tanto das atividades diretamente promovidas pela gestão quanto da interlocução com os usuários durante sua implementação - dois fatores redutores das oportunidades de interações interpessoais. Um número razoável de cursos de atividades esportivas foi mantido, sobretudo por haver professores efetivos de educação física, mas foram descartadas as parcerias anteriormente existentes com professores voluntários das comunidades. ${ }^{81} \mathrm{O}$ rol de cursos promovidos pelos núcleos de educação e cultura parece ter sofrido uma redução maior, não atraindo muitos interessados; as preferências das pessoas não pareciam figurar como critérios primordiais em sua definição. ${ }^{82}$

Na opinião de uma antiga funcionária efetiva da gestão, a população não sabia "dar valor" a cursos que não fossem futebol ou balé, por conta da "formação dos pais". Em sua avaliação, mesmo parte das matrículas era motivada por mães que queriam "livrar-se" da presença dos filhos. ${ }^{83}$ Observação semelhante foi feita por gestores do CEU Vila Rubi, que no entanto usaram um tom mais conciliatório, interessado em preservar a criança afetada por esse tipo de atitude e mais disposto a modificar o comportamento das mães. Na avaliação da funcionária mencionada, a grande procura por cursos durante os primeiros anos do CEU Butantã devia-se a um entusiasmo inicial que fazia com que moradores das comunidades se inscrevessem em atividades sem saber dos seus conteúdos: "não tinham nada, quando apareceu foi literalmente o céu".

Uma explicação mais convincente para o afastamento do público passa pela diminuição de canais de diálogo, pela implementação de regras inibidoras da apropriação - ou seja, pela multiplicação de contextos separadores - e, como fica claro agora pelo depoimento da funcionária, pela estigmatização de parte da população de usuários do CEU. Quando se supõe

\footnotetext{
${ }^{81}$ Dois desses moradores e professores de futebol de salão queixaram-se a mim, em conversa de $02 / 10 / 2013$, da falta de oportunidades de participação no Núcleo de Esportes, em contraste com o que acontecia nos primeiros anos do CEU.

${ }^{82}$ Cursos como robótica e reciclagem lutavam para conseguir o número mínimo de matriculados exigido pela Prefeitura e sofriam com desistências posteriores. A oferta dos cursos parecia mais uma consequência da negociação com as ONGs incumbidas de sua implementação do que do atendimento ao interesse dos usuários. Numa reunião de colegiado de 25/04/2013 (já durante o mandato de Fernando Haddad), educadoras consideraram modos de fomentar o interesse por atividades que até então não haviam recebido atenção: fizeram-se sugestões de apresentação dos cursos nas salas de aula das escolas; discutiram-se problemas de sincronia entre os horários dos cursos e das saídas das escolas; e falou-se da necessidade de explicar melhor o conteúdo de cursos com nomes que a população tinha dificuldade em entender: cursos de "percussão" e "danças étnicas" não eram compreendidos. Fica claro que a interface entre CEU e população não era prioridade.

${ }^{83}$ Outra parte proviria de alunos de escolas particulares ou de bairros mais distantes e centrais da cidade - fato que reforça a já analisada divisão norte-sul, já que os cursos da gestão eram oferecidos no patamar sul do centro educacional. O educador Mário Sérgio Cortella refere-se a uma tendência em atribuir à escola uma função de personal mother, e relaciona o fato com a diminuição do tempo disponível para o cuidado dos filhos, tendo em vista a expansão das jornadas de trabalho (apud Oliva 2010, p. 23).
} 
que o desinteresse pelos cursos oferecidos se explica pela situação socioeconômica dos moradores das comunidades, atribui-se a eles uma essência cultural pouco passível de transformação. Nos termos de Herzfeld (2008), trata-se de uma essencialização, ou seja, da atribuição de uma identidade cultural homogênea com consequências práticas que vão muito além de uma escolha de palavras. Como diz o autor, essencializações "fazem coisas com palavras" (HERZFELD, 2010, p. 49, 51, 261); no caso, elas aparecem inibindo iniciativas mais favoráveis ao acolhimento.

Estes fatores aparecem mais evidentemente combinados na fala de uma das funcionárias nomeadas do Núcleo de Ação Cultural. ${ }^{84} \mathrm{Na}$ escolha da programação da Virada Cultural de 2010, a funcionária foi contrária a sugestões de muitos usuários em convidar a cantora Gretchen, preferindo a dupla de artistas sertanejos Xangai e Elomar, observando que "o tipo de pessoa que gosta de Gretchen não é aquela que eu quero aqui dentro". Se esta fala nos lembra a inevitável influência que um gestor cultural exerce na definição da programação de um centro educacional, ela também denota certa despreocupação em medir ou modular esta influência, em se dispor a negociar preferências e pontos de vista distintos. A servidora minimiza a importância da baixa procura pelas atividades por ela promovidas, entendendo-a como etapa de uma atuação voltada ao objetivo de ir "formando um público com mais qualidade", que no entanto parece não ter se constituído ao longo de seus oito anos de atuação. Antes, a preocupação em elevar a "qualidade" do público e a estigmatização desse público - classificando-o em termos de "tipos" pouco sujeitos à transformação - parecem indicar duas operações contraditórias, que no entanto oferecem motivos diferentes para as mesmas práticas: ambas justificam o reforço de assimetrias de poder através da diminuição da disposição em dialogar e da ampliação de contextos separadores. Estes últimos são capazes de forçar o afastamento de grande parte dos frequentadores do CEU - sobretudo e justamente aqueles que "precisam" ser "formados", e que são, ao mesmo tempo, discriminados na construção dos "tipos".

A participação na esfera administrativa, consubstanciada pelo conselho gestor, também revelou-se reduzida. Quando, no segundo semestre de 2011, solicitei participar do conselho gestor do CEU, algumas reuniões ocorreram sob a justificativa de que eu estava presente, e envolveram não mais do que três ou quatro funcionários da gestão. A gestora entendia as ausências como desinteresse da parte dos membros do conselho, composto por moradores do

\footnotetext{
${ }^{84}$ De acordo com depoimento concedido a mim em agosto de 2010.
} 
entorno, por servidores dos equipamentos do CEU e por membros da própria gestão. Com isso parecia ver motivos para espaçar as reuniões e justificar tomadas de decisão por conta própria. Por outro lado, apurei dois depoimentos que relacionavam suas ausências a uma forma sutil de manifestar insatisfação com os gestores. ${ }^{85}$

Fica claro, assim, que a diminuição das interações tende a produzir confusões de sentido difíceis de deslindar. O escasseamento do contato dos gestores com os moradores das comunidades também parece incentivar as essencializações já mencionadas, na medida em que as pessoas deixam de renovar ou atualizar a imagem que possuem umas das outras, passando a trabalhar com a construção recíproca de identidades caricatas e estereotipadas. Imprecisões de sentido e estigmatizações dificultam uma retomada de diálogo, favorecendo a estabilização dos afastamentos.

Convém salientar que, a despeito das separações, permanece uma combinação de extensividades, garantindo às pessoas a possibilidade de retomada de diálogo. Especificamente em relação ao âmbito espacial, apesar de tentativas de fechamento do espaço interno do CEU, a abertura e amplitude garantidas pelo projeto de arquitetura continuavam assegurando a possibilidade do livre trânsito e da escolha pela interação. De modo mais amplo, é importante observar que a participação em todas as atividades analisadas até o momento é de caráter voluntário: falamos de eventos e cursos de cunho esportivo, cultural ou educacional, além da participação em conselhos gestores, entre outras oportunidades de colaboração e participação que dependem do interesse das pessoas. ${ }^{86} \mathrm{O}$ caráter voluntário da frequência a essas atividades fica claro quando as comparamos com o universo da educação, ou seja, com os vínculos fortes ou compulsórios que ligam alunos e professores às instituições escolares. É destas últimas que provêm, aliás, os gestores dos CEUs (com isso adiantamos uma problemática do fim do

\footnotetext{
${ }^{85} \mathrm{Um}$ desses afastamentos foi o da já mencionada liderança comunitária Fernanda Alvez, que era vice-presidente do conselho gestor. Em palestra durante a Reunião de Antropologia do Mercosul (2011) a antropóloga Carla Costa Teixeira apontou para um mecanismo segundo o qual a construção de instância para participação pode servir de base para acusações de falta de interesse em participar, desta forma legitimando assimetrias de poder e indo no sentido contrário ao originalmente pretendido. No CEU Vila Rubi, em contraste com o observado no CEU Butantã, a falta de interessados em participar das reuniões de conselho cultural foi enfrentada de outra maneira pela coordenadora do Núcleo de Ação Cultural daquela instituição. As reuniões prosseguiram, mesmo que contassem com um ou dois participantes, até que o número de interessados passou a aumentar - segundo depoimento dado por ela em maio de 2013.

${ }^{86}$ Já observamos também, ao analisar os cursos e canais de participação oferecidos nos primeiros anos deste CEU, que as atividades de grande interesse para os participantes podem funcionar como contextos intensivos, induzindo as interações. As que não despertam interesse especial - como parece ter sido o caso de boa parte das atividades promovidas entre 2005 e 2012 - tendem a funcionar como contextos extensivos.
} 
capítulo).

\subsubsection{Afastamentos, acomodações e intensividades}

Em síntese, num primeiro momento da história deste centro educacional observamos uma maximização da extensividade com a atuação de gestores primordialmente interessados no acolhimento: efetivaram-se canais de participação e diálogo; ampliaram-se oportunidades para interação através da promoção de cursos e atividades; e isso em meio a um espaço físico amplo e aberto (todos esses fatores jogando a favor do aumento da liberdade de ações e interações, e consequentemente do aumento da incerteza). Num segundo momento, gestores prioritariamente preocupados com a segurança e a organização enxergaram como secundárias a maximização da liberdade e a qualidade do atendimento, introduzindo separações de diversos tipos. As separações procuraram combater extensividades que, no entanto, permaneceram, ainda que enfraquecidas: o contexto extensivo que melhor resistiu foi o espacial, mas atividades e canais de participação da gestão mantêm-se essencialmente voluntários e, portanto, extensivos.

Note-se que as extensividades e separações foram vistas pelos partidários de umas e de outras como dicotômicas e mutuamente excludentes: num primeiro momento (2003-2004) minimizaram-se as regras para favorecer a liberdade; posteriormente (2005-2012), implantaramse regras para diminuir a liberdade, sem que se conseguisse extingui-la. No entanto, as separações e extensividades não se opuseram da forma prevista. $\mathrm{Na}$ verdade, os efeitos combinados de contextos extensivos e separadores reforçaram-se: os primeiros garantiram a liberdade de declinar das interações, os segundos forçaram este declínio. As pessoas se afastaram em parte porque queriam e em parte por serem levadas a isso. Combinaram-se os afastamentos voluntários e involuntários, produzindo-se uma singular desaceleração das interações. A rarefação de contatos favoreceu a criação de confusões de sentido e estigmatizações, e estas, por sua vez, tenderam a estabilizar os afastamentos. Não é de estranhar, portanto, que o próximo tópico relatará dificuldades expressivas encontradas pelos gestores que assumiram este centro educacional em 2013 para reverter esse quadro.

Entre os afastamentos, podemos estabelecer distinções. Num extremo, há conflitos acirrados presididos quase que exclusivamente por extensividades. Nestes casos os afastamentos podem ser totais e irreversíveis, a exemplo daqueles que ocorreram com certos frequentadores das quadras de esportes em 2005, quando houve mudança brusca no estilo de gestão do CEU. No 
outro extremo, há os desentendimentos mais brandos ocorridos sob pequenas doses de intensividade, que obrigam as pessoas a interagirem ocasionalmente. No CEU Butantã, sempre que o predomínio das extensividades e das separações combina-se com um convívio obrigatório e esporádico, formam-se afastamentos incompletos que permitem evitar trocas interpessoais mais expressivas e produzem acomodações de parte a parte. As acomodações representam uma dinâmica limítrofe em relação ao afastamento, e também são muito comuns neste centro educacional.

Há acomodações entre aqueles funcionários do CEU Butantã obrigados a um convívio esporádico por trabalharem em equipamentos diferentes. Um exemplo está na forma como EMEF, EMEI e CEI passaram a compartilhar os espaços dos fundos do centro educacional. O acesso a esses espaços foi restrito, em meados da década passada, exclusivamente ao lazer de alunos das escolas. A diferença entre faixas etárias desses alunos exigia o estabelecimento de áreas e horários de utilização exclusivos. Porém, isso foi se delineando somente com o passar dos anos, já que a busca de consensos explícitos, empreendida pela coordenadora pedagógica de uma dessas escolas, não era a atitude adotada pelos educadores das outras unidades. ${ }^{87}$

Acomodações também ocorrem quando funcionários preocupam-se sobretudo em cumprir suas obrigações protocolares, minimizando esforços e contatos interpessoais. Por exemplo, reclamações ocasionais referiam-se a seguranças que, prestando serviço na guarita do P6, atentavam exclusivamente para a preservação do patrimônio público, obedecendo ao serviço especificado em contrato. Ao fazê-lo, isentavam-se de coibir o consumo de drogas, de ajudar no controle do fluxo de crianças ou de intervir em brigas de adolescentes. Na já mencionada plenária destinada a discutir a implantação de carteirinhas, um jovem relatou que, no mesmo dia, fora provocado e agredido por um grupo de adolescentes, sendo salvo pela intervenção de uma senhora idosa empunhando uma bengala - enquanto o segurança, que assistira ao início do

\footnotetext{
${ }^{87}$ Em depoimento prestado a mim em 23/04/2013, a educadora conta que enviava e-mails comunicando os horários em que suas turmas utilizariam o parquinho. Não recebia resposta, mas com o tempo seus horários acabaram sendo respeitados. No entanto, sempre havia risco de uso concomitante por faixas etárias diferentes. Neste caso, acionavam-se separações espaciais: os alunos da EMEI ocupavam apenas o patamar inferior, e os da EMEF ficavam no patamar superior. A divisão também foi sendo construída junto aos alunos, já que no início os mais velhos quebravam os brinquedos das crianças mais novas, alegando que os brinquedos também pertenciam a eles - depois, foram mudando seu comportamento. Outro exemplo de consenso por acomodação está na forma como o teatro era ocupado pelas duas escolas durante apresentações para o público infantil. Com o tempo, alunos da EMEF aprenderam a ocupar os assentos laterais e superiores do auditório, deixando aos alunos da EMEI os assentos frontais inferiores, de acordo com o referido depoimento.
} 
conflito, afastava-se do local, fechando-se no interior de sua guarita. ${ }^{88}$ Podemos dizer que, ao afastar-se, o funcionário ativou uma extensividade, e ao fechar-se na guarita ativou uma separação, justificando sua atitude pela intensividade mínima contida no escopo de sua contratação.

Vemos que os contextos intensivos neste CEU constituem-se em grande parte por vínculos empregatícios, que obrigam funcionários a interagir minimamente entre si e com os usuários. Mas há também um segundo tipo importante de intensividade - por sinal bastante peculiar, porque não apenas preside as interações, como deriva delas. É que certos conflitos tendem não apenas a gerar afastamentos e acomodações entre as pessoas, como terminam por expandir os territórios de uns e outros, até que se produzam inevitáveis conflitos entre esses territórios. Em outras palavras, ao mesmo tempo em que se afastam, as pessoas tendem a expandir suas áreas de influência até que estas entrem em conflito. Em princípio parece estranha a ideia de disputas por espaço num CEU dotado de áreas tão grandes; mas o CEU Butantã mostra justamente que territórios amplos possuem bordas mais difíceis de serem vigiadas, podendo acirrar esforços e controvérsias de demarcação.

Essa dinâmica oferece um olhar renovado sobre a divisão norte-sul desse centro educacional. De início identificamos um afastamento entre moradores das comunidades, ao norte, e frequentadores e funcionários dos equipamentos do $\mathrm{CEU}$, ao sul. Agora, podemos observar que, se esses públicos mantiveram-se afastados, seus respectivos territórios estão próximos, configurando contiguidades e intersecções conflitivas. Uma dessas intersecções localiza-se na área das piscinas, tão cobiçadas pelos jovens moradores do entorno quanto altamente controladas pela gestão, por conta de riscos de acidentes e transmissão de doenças. Embora se mantenha vigiado, gradeado, tendo sua utilização inibida por muito tempo, o espaço não deixou de ser invadido por jovens interessados seja em desafiar a autoridade dos gestores, seja em apropriar-se de um equipamento classicamente associado a privilégios de classe, seja simplesmente em banhar-se durante o curto período precedido pela chegada de seguranças.

Uma territorialização de menor escala acontece em torno da pista de skate. Muitos

\footnotetext{
${ }^{88}$ A própria gestora mostrou-se indignada com o ocorrido: "Se eles [seguranças] estão vendo uma briga [...] eles têm a obrigação de interceder, porque queira ou não queira quem está num equipamento educacional também tem que ser educador. Não dá pra se furtar disso, né, eu não posso ver uma briga, eu não posso ver alguma coisa errada acontecer e falar: 'não, eu só vou tomar conta dessa mesa, porque o patrimônio é do CEU.' Não, eu tenho que, até como ser humano, né, interceder e ajudar, não é só isso, né, embora o contrato seja muito frio, que a gente trata com a lei, mas eu acho que quem trabalha numa escola, né, em três escolas, não dá pra se omitir a isso".
} 
professores e pais de alunos evitam por completo a encosta que aloja o patamar da pista, por ser comumente associada a comportamentos agressivos e ao consumo de drogas. Se o território da pista suscita preocupações, raros são os relatos que se referem de fato aos skatistas, o que mostra que afastamentos interpessoais convivem com proximidades territoriais.

Intensividades entre territórios parecem regular também as relações entre funcionárias da limpeza do CEU, que dividem áreas a serem limpas em função de responsabilidades exclusivas. Certa vez a diretora do CEI solicitou a uma das faxineiras que limpasse uma área do pátio que tinha recebido vômito de uma criança. A faxineira recusou-se, sob alegação de que o lado do pátio em que estava a sujeira não era de sua responsabilidade, e que sua colega limparia durante o próximo turno de trabalho. Para que sua solicitação fosse atendida, a diretora foi obrigada a reforçar o pedido, lembrando a funcionária da assimetria de poder existente entre elas. ${ }^{89}$ Enfim, esses exemplos mostram que animosidades presididas por extensividades e separações no nível interpessoal tendem a relacionar-se com a produção de intensividades no nível interterritorial. ${ }^{90}$

\subsection{5 "Retomada" do acolhimento (2013-2014)}

A posse de Fernando Haddad, no início de 2013, trouxe o Partido dos Trabalhadores de volta ao poder executivo paulistano pela primeira vez desde a gestão Marta Suplicy. Os CEUs voltaram ao centro da agenda política pela primeira vez desde a gestão petista anterior, com a previsão de implantação de 20 novas unidades e a mudança de servidores públicos nas diretorias regionais de ensino e nas gestões dos CEUs existentes. Dada a novidade das mudanças, análises desenvolvidas sobre esta nova etapa seriam prematuras. Mesmo assim, há pontuações importantes que merecem ser feitas sobre certos desdobramentos de dinâmicas anteriormente analisadas.

Em primeiro lugar, os servidores públicos que assumiram os postos de comando infundiram no cotidiano dos CEUs um clima de "resgate" ou de "retomada do projeto original". Com isso, reforçou-se a já conhecida distinção entre partidários e adversários do acolhimento, e entre os dois mandatos petistas e aqueles que lhes serviram de intervalo. Para ilustrar o ponto, vejamos as palavras de André Luís Bafume, diretor da Diretoria Regional de Ensino do Butantã,

\footnotetext{
${ }^{89}$ Conforme conversa que travei com a diretora, em 03/07/2013.

${ }^{90}$ No capítulo 3 analisaremos um exemplo de intensividade territorial entre ambientes diferentes da biblioteca deste centro educacional.
} 
durante a cerimônia de posse do novo gestor do CEU Butantã:

Francisco [Francisco Bernardino Leite, novo gestor do CEU Butantã] tem pela frente o desafio de retomar o projeto de CEU que seja para todos e que possibilite [...] trazer aqui a cultura popular, trazer para cá, para que possa ocupar esse palco, a população [...] que existe aqui ao nosso redor [...] esse é um novo tempo que nós marcamos com a data de hoje na cidade de São Paulo, nos 45 CEUs espalhados por todos os cantos da nossa maravilhosa cidade. Para que de fato [...] os CEUs voltem a fazer parte do espaço de cultura dessa cidade. (grifos nossos) ${ }^{91}$

Na cerimônia, assistiu-se à reedição da veemência com que o acolhimento foi promovido durante a gestão Marta Suplicy, não havendo intenções de amenizar antagonismos, mesmo com a presença de muitos servidores pertencentes ao lado criticado. ${ }^{92}$ Nos meses seguintes, antigos funcionários nomeados que ainda permaneciam no CEU criticavam o termo "recomeço": de seu ponto de vista, era "como se a gente não tivesse feito nada". Um dos comentários feitos observava que, se normalmente um funcionário começa a ser avaliado com reputação "zero", a deles havia começado com "menos dez". ${ }^{93} \mathrm{O}$ desconforto também era sentido entre os funcionários efetivos e certamente alimentou desejos de antagonismos, inibindo ainda a adesão ao acolhimento por parte daqueles com posições mais intermediárias de valores e preferências políticas. No sentido inverso, a veemência na defesa do acolhimento e das práticas democráticas também suscitava críticas aos novos dirigentes, interessadas em apontar contradições entre discursos e práticas. Ganharam destaque as controvérsias sobre a condução do processo seletivo para a escolha dos gestores, alegadamente conduzido por dirigentes das Diretorias Regionais de Ensino de modo isento e idôneo, mas que sabidamente buscou acomodar indicações de vereadores e políticos da base aliada do novo governo. ${ }^{94}$ Mesmo assim, é importante assinalar

\footnotetext{
${ }^{91}$ A cerimônia de posse do educador Francisco Bernardino Leite ocorreu em 20/04/2013. Na mesma data tomaram posse outros gestores de CEUs. Francisco ocupou o cargo durante cerca de um ano, sendo seguido pela educadora Sabrina Teixeira.

${ }^{92}$ Uma das falas oficiais referiu-se explicitamente a um "abandono" dos CEUs, obviamente incluindo o período presidido pela falecida gestora Elisabete Gaspar Tunala, cuja filha estava no auditório representando sua mãe. A fala foi considerada deselegante por funcionários sentados em cadeiras próximas à minha, no auditório.

${ }^{93}$ Conforme conversa entre funcionários nomeados, presenciada por mim em 23/04/2013.

${ }^{94}$ Servidores antigos dos CEUs chegaram a lembrar que outros gestores não haviam sido escolhidos por processos seletivos semelhantes. Portanto, os novos não precisavam sê-lo também, a não ser pela intenção de construir uma fachada legitimadora de escolhas que, segundo eles, teriam obedecido a outros critérios. Uma fonte da diretoria regional de ensino observou, certa vez, que a decisão de destituir todos os gestores em exercício partira do alto escalão da Secretaria de Educação. Eles foram aceitos como candidatos no processo seletivo, mas nenhum foi mantido no cargo - nem mesmo gestores como o do CEU Vila Rubi, que atraiu com sucesso a frequência das comunidades do entorno e estava claramente comprometido com o acolhimento.
} 
que o critério de escolha parece ter se alinhado, em muitos casos, com a promoção do acolhimento.

Também retorna ao cotidiano do CEU Butantã a intenção de configurar um predomínio de contextos extensivos. Mas o reforço dos canais de participação política, a disponibilização de espaços e recursos fomentadores de encontros interpessoais, e a promoção de atividades e eventos de frequência voluntária enfrentam grandes desafios para atrair interessados, acostumados ao quadro de animosidades e estabilização de afastamentos que analisamos até o momento.

No âmbito da participação política, a extensividade ampliou-se com o reforço das reuniões do conselho gestor. Elas passaram a acontecer regularmente, atraindo um público assíduo composto por diretoras e educadores de CEI, EMEI e EMEF, e alguns participantes de frequência intermitente. Convites por e-mail e mesmo presenciais passaram a ser realizados para alcançar também entidades e moradores do entorno, fazendo frente à tendência estabilizada de afastamento. No entanto, ao longo de 2013, as interlocuções passaram a ser permeadas por insatisfações. Parte das dificuldades certamente provinha do ineditismo das reuniões. Outra parte, notada por alguns participantes e talvez mais particularmente por mim mesmo, devia-se a uma maneira espontânea e livre de conduzir o debate. Vale a pena indagar a hipótese de relação entre esse estilo de condução do debate e o privilégio dado à extensividade, que neste caso preside o interior mesmo das reuniões: na medida em que a livre escolha em falar e interagir é maximizada, aumenta-se o risco de incerteza na condução do diálogo, com participantes predominantemente orientados por suas próprias dinâmicas e necessidades. ${ }^{95}$ A consequente desorganização também poderia ser compensada com a introdução de contextos separadores, neste caso capazes de limitar a liberdade de uns e outros, em favor do conjunto. ${ }^{96}$

Quanto às atividades e eventos promovidos pela nova gestão, a ampliação acabou sendo

\footnotetext{
${ }^{95}$ As insatisfações, bem como os esforços interessados em solucioná-las, referiam-se principalmente aos seguintes problemas: reuniões que não chegavam ao final da pauta, parando em longas discussões dos primeiros itens por participantes que tomavam a palavra por períodos prolongados; muitos participantes faltavam, chegavam muito atrasados ou ausentavam-se temporariamente, prejudicando a legitimidade das decisões coletivas; não cumprimento de decisões tomadas, ou demora excessiva em implementá-las; finalmente, muitos problemas terminavam sendo rediscutidos sem que chegassem a ser resolvidos.

${ }^{96}$ Fora das reuniões, certas interações entre os novos gestores e funcionários resistentes às mudanças também pareceram delegar bastante importância à extensividade. Por exemplo, funcionários efetivos e terceirizados do CEU, nitidamente avessos à promoção do acolhimento e excessivamente preocupados com a própria segurança, foram abordados segundo a ideia de que "têm que ganhar as pessoas". Certos funcionários não se predispunham a mudar de conduta com estas aproximações, e exerceram forças disruptivas para o esforço de promoção do acolhimento.
} 
limitada pela manutenção de um aporte reduzido de recursos aos CEUs em geral (aparentemente em função da má situação das contas públicas do município). Merece destaque especial a promoção de atividades junto ao público frequentador da pista de skate, composto em sua maioria por jovens moradores das comunidades do entorno - justamente aqueles que estiveram mais sujeitos a estigmatizações e desconfianças por parte de certos professores, pais de alunos e antigos gestores. Boa parte desse público pertence ao Butanclan, um grupo de contornos difusos que reúne moradores das comunidades ao norte do CEU vinculados às práticas do hip-hop e afins. ${ }^{97}$ A aproximação com a gestão, e particularmente com o coordenador de Ação Cultural, Caio Nascimento Uehbe, consolidou-se com a instalação de um palco ao lado da pista, que passou a ser usado em campeonatos de skate e shows de música, dentre outros eventos. Para o sucesso da iniciativa, parece ter sido decisiva a vinculação de Caio Uehbe ao universo da música e da produção cultural de periferia, bem como a seus valores e códigos de sociabilidade. Este é um primeiro indício da importância que artistas e produtores culturais podem ter na condução da gestão dos CEUs, assunto que será desenvolvido ao final deste capítulo.

A aproximação dos novos gestores foi mencionada com satisfação em conversas que travei com alguns frequentadores da pista. Muitos jovens parecem ter mudado seu comportamento dentro do centro educacional, a julgar pelo depoimento prestado a mim por um dos seguranças responsáveis pelo P6, em 10/08/2013. Como únicos representantes institucionais da porção norte do CEU, os seguranças enfrentam dificuldades diárias para zelar pelo cumprimento de normas como proibições de alimentar ou pescar peixes do lago, restrições a bicicletas e pipas, preservação de equipamentos, entre outras. No depoimento citado, o segurança associou o aumento da disposição dos jovens em colaborar com a abertura para o diálogo empreendida pelos novos gestores. Isso suscita uma comparação entre os tipos de contexto que estamos propondo no que diz respeito aos efeitos produzidos pelas aproximações em cada um deles. Se em contextos intensivos as aproximações são inevitáveis, elas tendem a carregar, em maior ou menor grau, a dúvida sobre o interesse real que as motiva. Por outro lado, em contextos extensivos, as aproximações são facilmente entendidas como voluntárias e sinceras, ampliando a disposição para o mútuo entendimento e a reciprocidade.

No entanto, não foi apenas para as reuniões do conselho gestor que a extensividade trouxe

\footnotetext{
${ }^{97} \mathrm{O}$ grupo existe desde o início da história do CEU Butantã e reúne-se também no bar Recanto dos Skatistas, situado a poucos metros do P6. É notável que os gestores anteriores pouco soubessem desse grupo.
} 
sua parcela de incerteza. Conforme atividades e espaços passaram a ser oferecidos, a frequência ao CEU aumentou, assim como aumentou o número de ocorrências indesejadas. Ao reforçar a extensividade, os novos gestores faziam com que o CEU se tornasse especialmente vulnerável a elas. Por exemplo, ao longo de 2013, a EMEF enfrentou grandes dificuldades para conter a ação de jovens ex-alunos da instituição, que se divertiam em provocar alunos e funcionários que transitavam pelo patamar sul do CEU. Nem o diálogo nem mesmo a convocação ocasional da Guarda Civil Metropolitana fez com que esses ex-alunos mudassem de conduta. As piscinas, que passaram a receber diariamente diversos visitantes, também conheceram conflitos importantes entre grupos de moradores de comunidades diferentes. Um exemplo divertido das consequências da maior extensividade refere-se a Valdir, um senhor idoso e alcoólatra que passa a frequentar diariamente, e sem cerimônias, os escritórios da equipe gestora. Inspirado pelo acolhimento, Valdir compõe músicas e poemas dignos de nota, que suscitam a admiração de funcionários (e deste pesquisador). Depois de meses de visitas sucessivas ao CEU, ele passa a ser considerado inoportuno, interferindo no andamento de reuniões e em outros tipos de trabalho. Diante dos crescentes pedidos para que se mantivesse a distância, Valdir irritou-se, entrou em conflito com uma funcionária e terminou por se afastar definitivamente do CEU.

Outro exemplo de incerteza derivado da extensividade refere-se a roubos de computadores e equipamentos ocorridos no início de 2014. Já observamos que, para a educadora Anna Cecília Simões, ocorrências desse tipo são esperadas e consideradas necessárias dentro de um processo de construção de mútuo entendimento e reciprocidade. No entanto, esta pesquisa pretende questionar justamente a atribuição de um valor invariável e exclusivamente positivo à extensividade e à liberdade de ação e interação. No CEU Vila Rubi encontraremos iniciativas não menos comprometidas com o acolhimento, porém mais afeitas a uma calibragem fina de contextos e ao estabelecimento de dosagens de intensividades, extensividades e separações. Com isso queremos dizer que o exercício do poder e o reforço de hierarquias, em parte realizados com o emprego de contextos intensivos e separadores, além de serem obviamente imprescindíveis para a promoção do acolhimento e de práticas democráticas, precisam ser conscientemente problematizados. Os instrumentos teóricos propostos por esta pesquisa e as análises por eles permitidas pretendem colaborar nessa direção. 


\subsection{CEU Vila Rubi: combinações de âmbitos e contextos}

A história do CEU Vila Rubi começa em 2007, passa pela superação de graves conflitos iniciais e transcorre sem grandes sobressaltos ao longo dos anos subsequentes. A equipe de gestores manteve-se no cargo por muito tempo, e mesmo as mudanças ocorridas em 2013, após a eleição de Fernando Haddad, trouxeram novos servidores interessados em dar continuidade ao trabalho já efetuado. Neste CEU, o acolhimento foi uma preocupação central, mas ele não se fez da forma veemente e explícita como ocorreu no CEU Butantã, nem se associou à maximização de contextos extensivos.

O âmbito da gestão continua sendo essencialmente extensivo, na medida em que o sucesso das atividades promovidas depende de adesões voluntárias de funcionários e frequentadores. No entanto, os gestores contaram com uma combinação de extensividades, intensividades e separações para direcionar as interações cotidianas, de modo que o acolhimento associa-se mais intimamente aos três tipos de contexto. Isso mostra que não há uma relação exclusiva $\mathrm{e}$ necessária entre acolhimento e extensividade, da forma pretendida pelos gestores que estiveram à frente do CEU Butantã em seus primeiros anos. Veremos também que as separações não foram empregadas no sentido de excluir ou afastar os usuários do centro educacional.

Para facilitar a exposição, os ítens subsequentes tratam separadamente de cada um dos contextos, mas muitos dos fatos analisados aparecem em mais de um item, o que revela o imbricamento alcançado por eles.

\subsubsection{Intensividades espaciais}

As características espaciais do CEU Vila Rubi são altamente intensivas, em parte por terem sido definidas por um projeto de arquitetura padronizado que procurou se contrapor à amplitude e abertura espacial dos primeiros CEUs, como vimos no capítulo anterior. Mas as interações cotidianas em seu interior são ainda mais condicionadas e concentradas devido às particularidades de sua situação urbana, da mesma forma como foi incrementada a extensividade no CEU Butantã. Assim, passamos do estudo de um contexto espacial altamente extensivo para o extremo oposto da intensividade de espaços. Procuraremos observar que a intensividade, no caso deste $\mathrm{CEU}$, está relacionada a um incremento no número de interações cotidianas, à produção de 
uma intercambialidade de papéis sociais e à redução da produção de estigmatizações interpessoais.

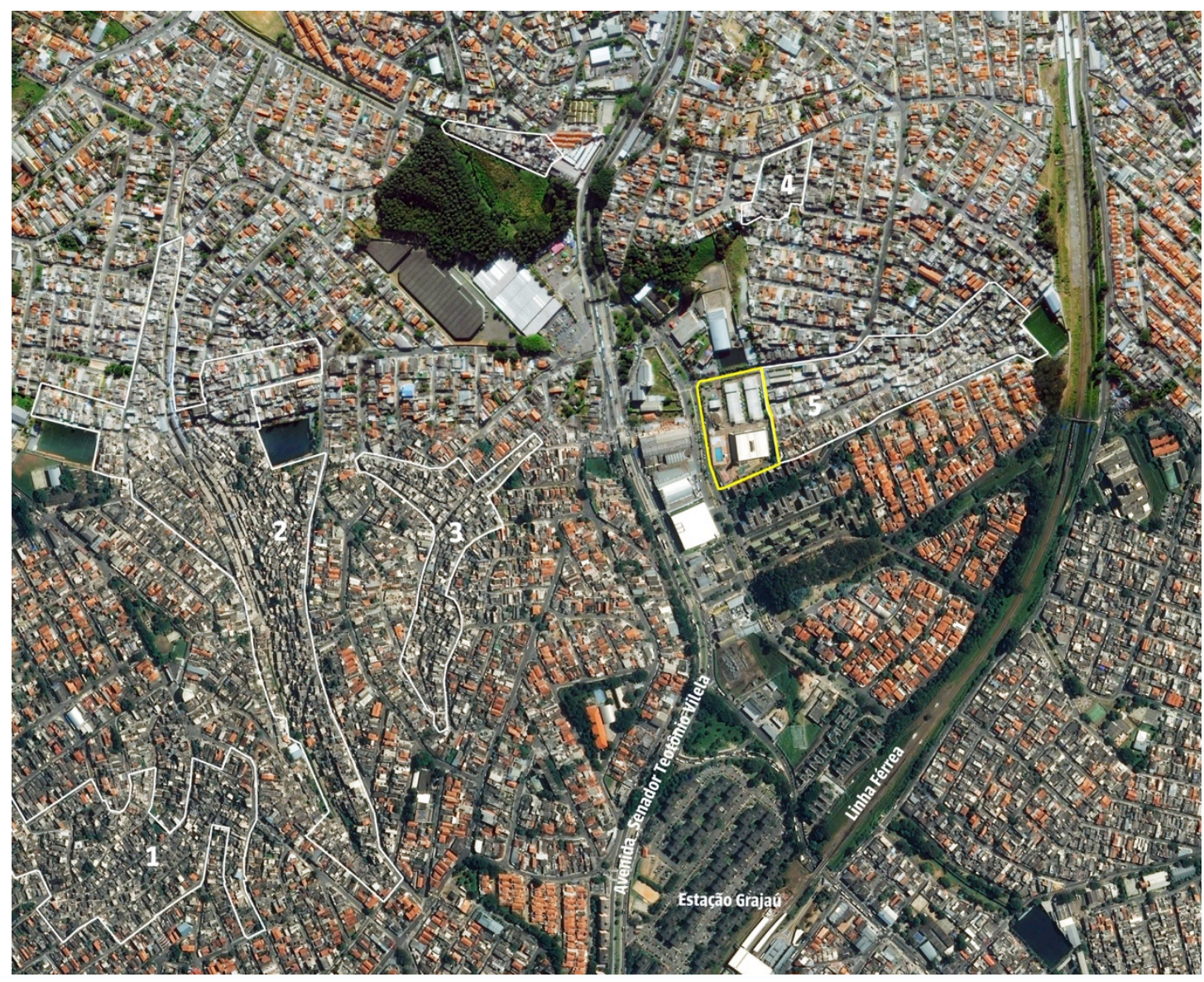

Figura 32 - Foto aérea do CEU Vila Rubi e entorno. Aglomerados "subnormais": 1-Jardim das Imbuias; 2-Iporanga/Jardim Bonito; 3-Jardim Presidente; 4-Parque Alto; 5-Vila Rubi. ${ }^{98}$

O CEU Vila Rubi localiza-se no bairro do Grajaú, na zona sul de São Paulo, numa porção consolidada de tecido urbano, posicionada entre as represas Billings e Guarapiranga, a poucos quarteirões dos eixos de macroacessibilidade representados pela Avenida Senador Teotônio Vilela, a oeste, e pela linha férrea, a leste. O entorno do CEU caracteriza-se como residencial de média densidade, abrigando tecidos de casas térreas e sobrados, conjuntos habitacionais de quatro andares e uma coleção expressiva e dispersa de aglomerados urbanos "subnormais", com

\footnotetext{
${ }^{98}$ Também neste caso os nomes mais conhecidos dessas comunidades parecem não coincidir com os oficiais, conforme dados da Assessoria Técnica de Planejamento e Pesquisa da Secretaria Municipal de Habitação - site www.habisp.inf.br (acessado em setembro de 2014). No mapa do site, a Vila Rubi não aparece como sendo vizinha ao CEU, da forma como preferimos indicá-la. Nomes não oficiais de comunidades, que colhi em campo: favela da Vinte, favela da Dezenove e favela da Tcheba. Vila Rubi, Parque Alto e Iporanga aparecem nos registros informais e oficiais.
} 
destaque para a comunidade da Vila Rubi, vizinha ao centro educacional. Disparidades de renda e classe social acontecem em toda a volta do CEU e não organizam polaridades regionais tão marcadas como as que vimos para o CEU Butantã.
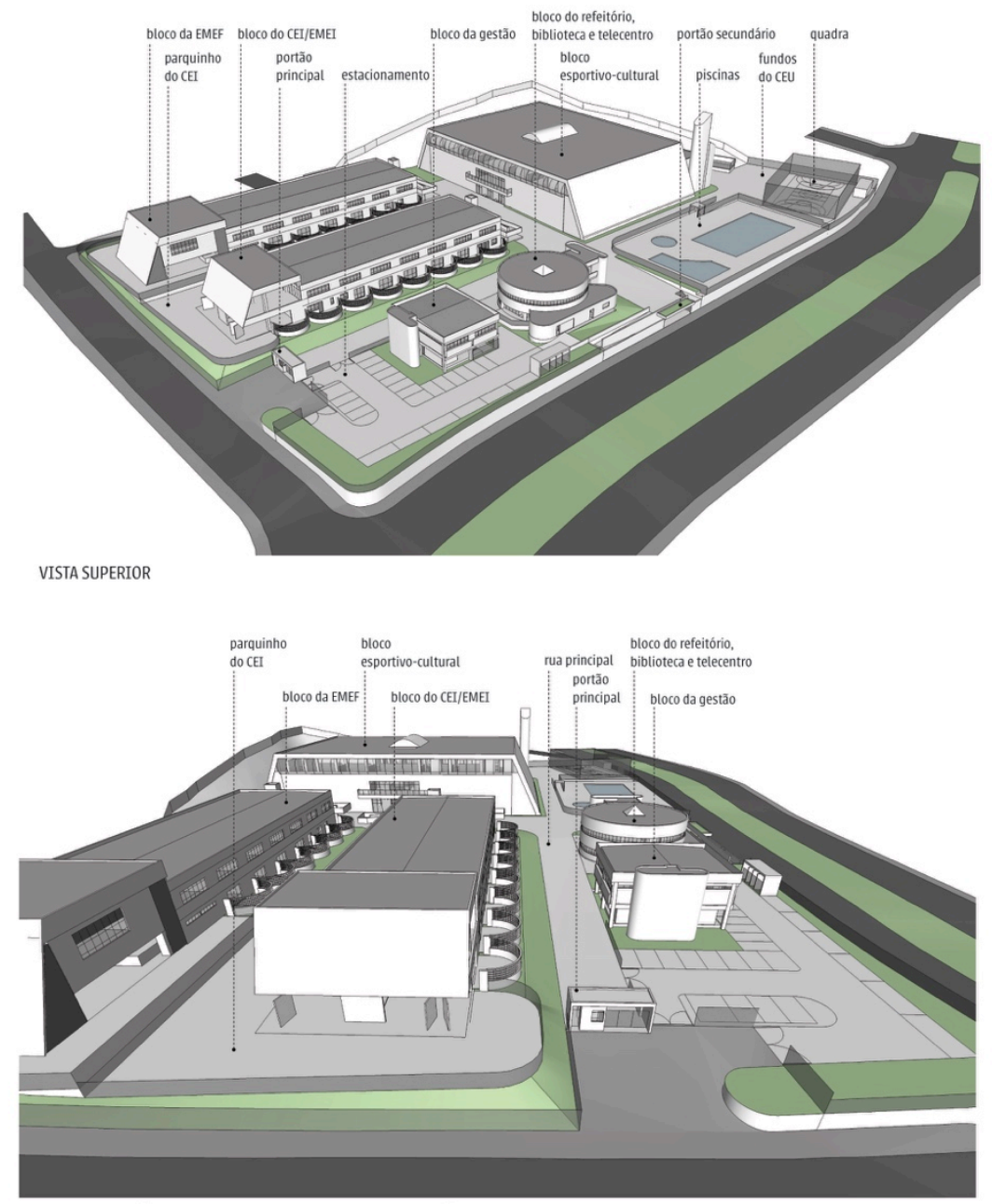

VISTA DO PORTÃO PRINCIPAL E RUA PRINCIPAL DE CIRCULAÇ̃̃O

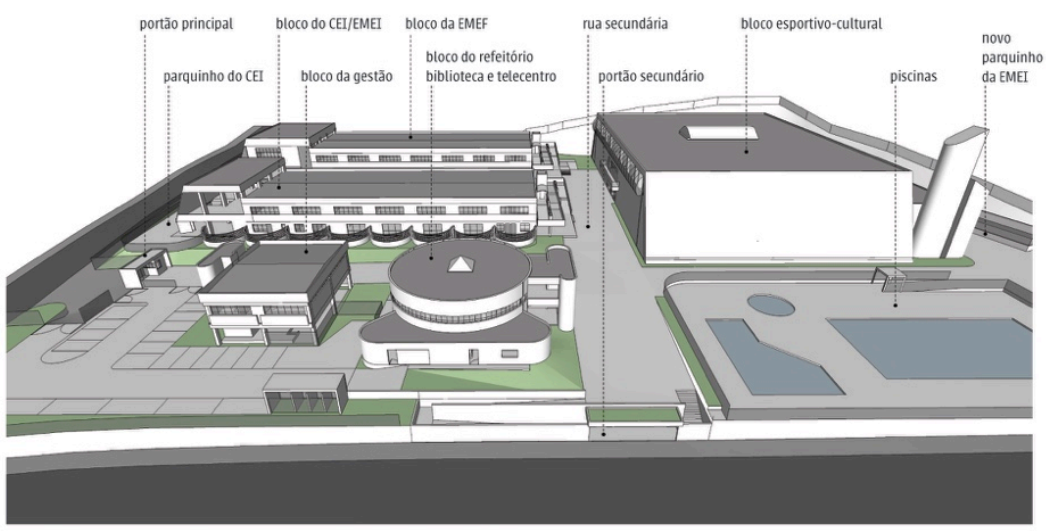

VISTA DO PORTÃO SECUNDÁRIO E EIXO SECUNDÁRIO DE CIRCULAÇÃO

Figura 33 - Perspectivas do CEU Vila Rubi. 
O terreno do CEU Vila Rubi é aproximadamente plano e retangular, e faz frente para duas ruas. Duas portarias abrem-se a lados perpendiculares do lote, mas não são suficientemente distantes para se associarem a públicos ou atividades diferentes. Isso acontece em parte por conta do tamanho reduzido do terreno, equivalente a menos de dois quarteirões urbanos, ou cerca de 17 mil metros quadrados - um terço da área do CEU Butantã. Some-se a esta exiguidade espacial aquelas produzidas por um projeto arquitetônico que implementou muros e grades para condicionar as circulações e ações dos públicos, além de distribuir os equipamentos do CEU em pequenos volumes edificados. $\mathrm{O}$ resultado foi a segmentação de espaços livres e a multiplicação de interstícios pouco passíveis de apropriação.

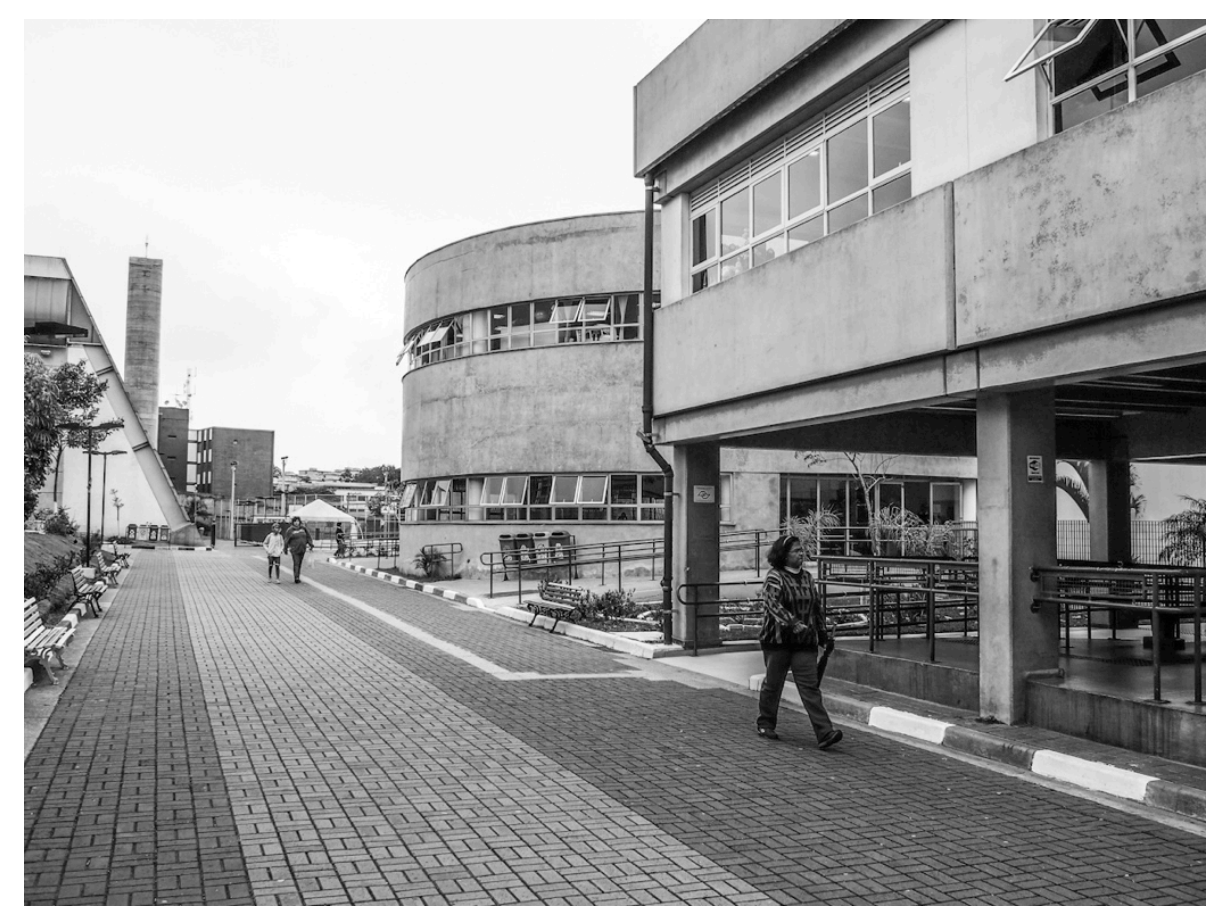

Figura 34 - Rua principal de circulação do CEU Vila Rubi, com edifício da gestão em primeiro plano e edificio circular do refeitório, biblioteca e telecentro ao fundo. 


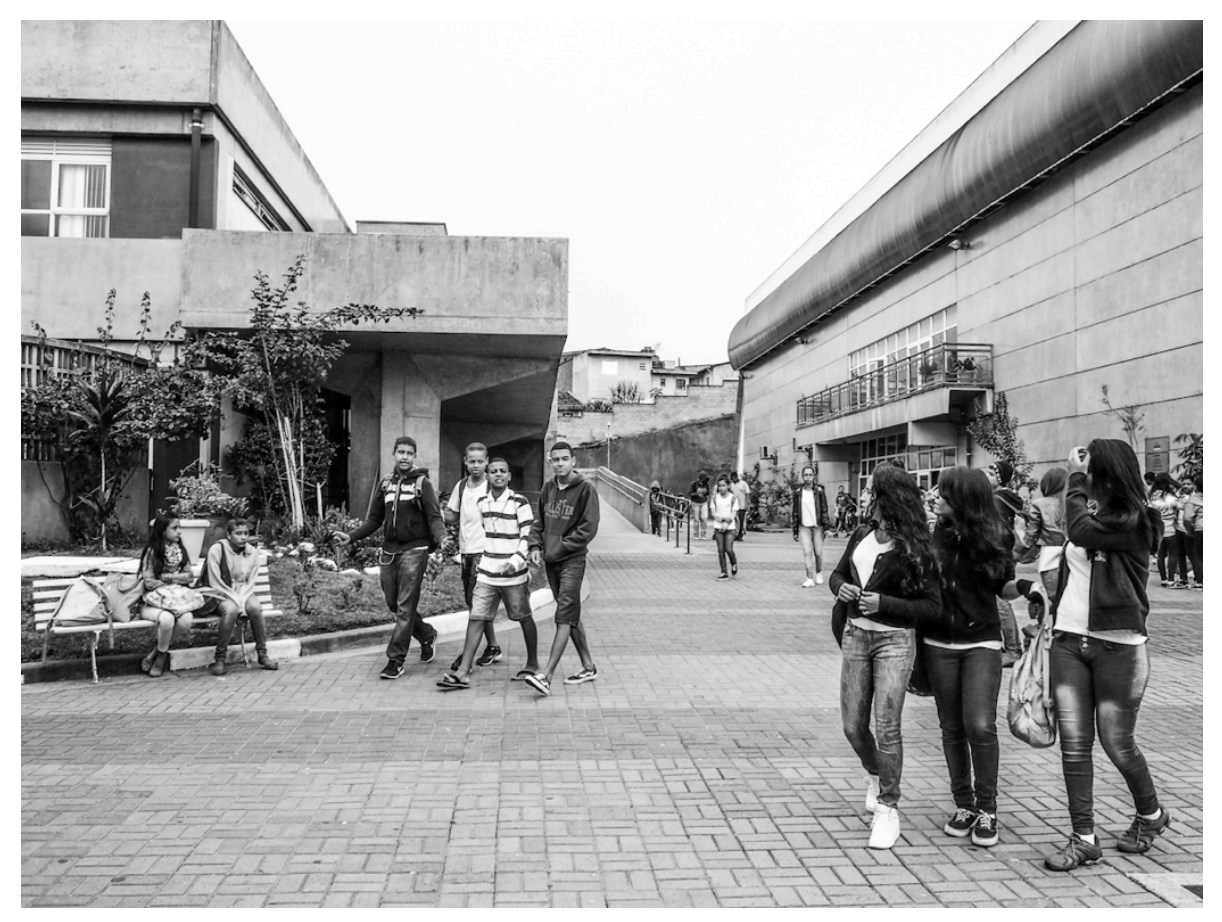

Figura 35 - Esquina e eixo secundário de circulação do CEU Vila Rubi, com edifício do CEI e da EMEI à esquerda e bloco esportivo cultural à direita.

Desta forma, os espaços para o trânsito e o convívio no interior do CEU praticamente se restringem a dois eixos perpendiculares de circulação, cada um começando em uma das portarias já mencionadas. Os eixos têm um aspecto de ruas urbanas, com guias, calçadas e edifícios em suas laterais. A rua principal dá acesso ao edifício de dois pavimentos da gestão do CEU e a um edifício circular de mesma altura, que abriga um refeitório no térreo, a biblioteca e o telecentro no primeiro andar. Do outro lado do cruzamento do eixo secundário de circulação encontram-se os acessos às piscinas, à quadra descoberta e a um parquinho utilizado pela EMEI. O eixo secundário, por sua vez, mais curto e largo, leva ao bloco esportivo-cultural - com teatro, ginásio e salas para cursos diversos - e a dois edifícios similares de dois pavimentos, que abrigam as escolas do CEU. ${ }^{99}$ Um desses edifícios é inteiramente ocupado pela EMEF, enquanto o outro é dividido entre CEI e EMEI, situadas respectivamente no primeiro e segundo pavimentos. Os interiores dos equipamentos são igualmente exíguos, quase sempre configurando salas, escadas e corredores de circulação com tamanhos próximos ao mínimo exigido por lei.

Potencialmente, os CEUs Butantã e Vila Rubi podem abrigar quantidades semelhantes de funcionários e usuários, mas o fato é que, enquanto a frequência ao CEU Vila Rubi é maior, os

\footnotetext{
${ }^{99}$ Os espaços internos destes edifícios podem ser observados nas figuras 13, 16, 17 e 18, do primeiro capítulo.
} 
espaços disponíveis para ocupação são muito menores. Desse modo, as interações interpessoais são mais numerosas, incluindo tanto aquelas procuradas pelas pessoas quanto as que elas declinariam ou mesmo prefeririam evitar. Existe, assim, um convívio maior de diferenças; as pessoas parecem mais habituadas a negociações, disputas e acordos.

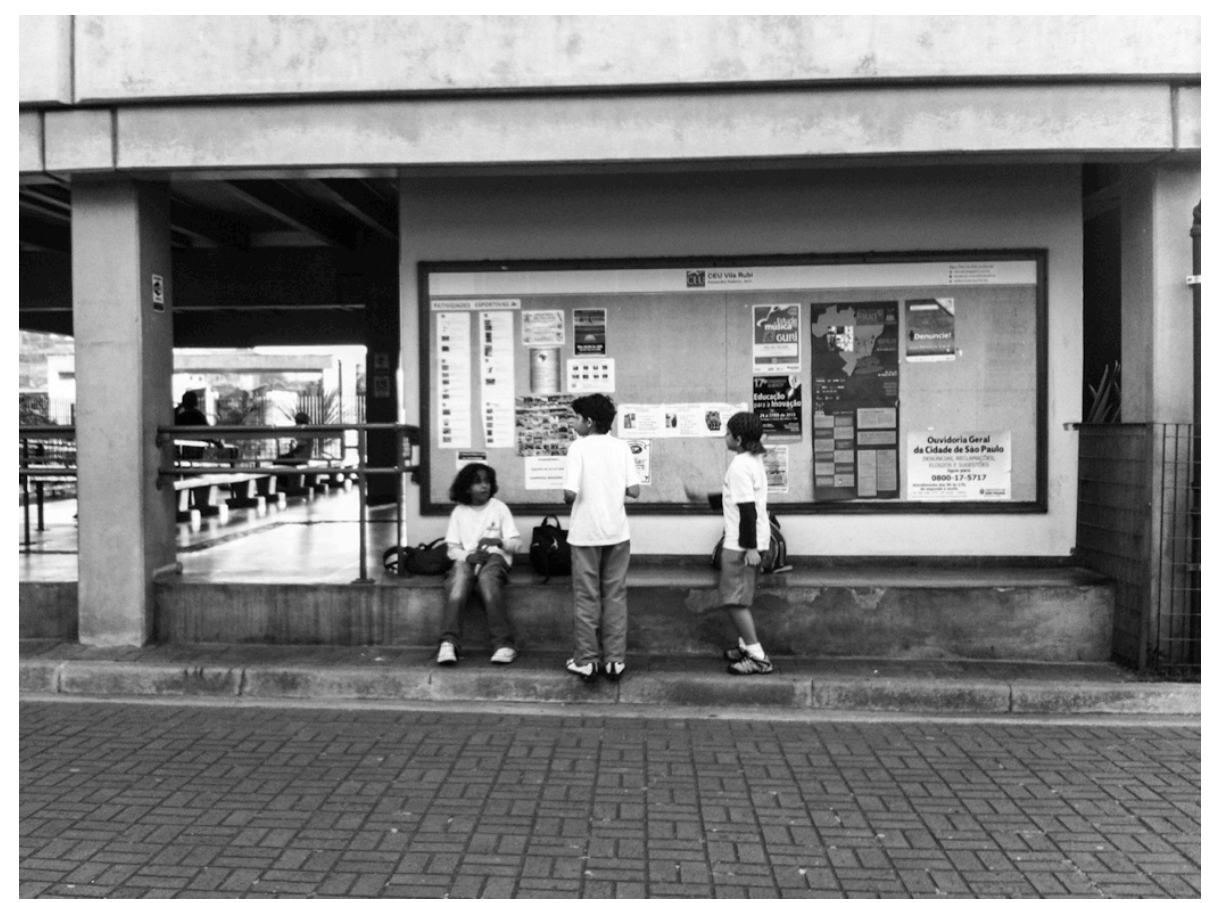

Figura 36 - Banco de concreto com meninos sentados, CEU Vila Rubi.

Certa vez, por exemplo, um grupo de cerca de sete alunas reclamava, para uma segurança feminina, do modo espaçoso com que dois colegas masculinos ocupavam o único banco de concreto localizado na lateral da rua interna do CEU. Os meninos mantinham-se calados e limitavam-se a assistir, contrariados, ao diálogo. As jovens diziam que eles sentavam-se ali todos os dias e que naquele dia eram elas que queriam utilizar o banco, solicitando à guarda que tirasse os meninos dali. A segurança pediu mais explicações, falando, em tom conciliatório, que não poderia ordenar a saída de alguém do lugar em que se encontra, ${ }^{100}$ e recomendando o compartilhamento do banco. Uma das meninas disse: "mas olha o jeito como eles sentam!" - e apontou para as pernas abertas dos meninos, para o espaço vazio entre eles e para os espaços ocupados por suas mochilas. Outra adolescente observou que o espaço ocupado por eles era

\footnotetext{
${ }^{100} \mathrm{~A}$ argumentação das alunas parece indicar um esboço de regra de revezamento que, se efetivada, poderia se constituir como um contexto separador, regulador da intensividade, de forma semelhante à que veremos num tópico seguinte, quando nos voltarmos para as separações.
} 
suficiente para que todas elas se sentassem. Mesmo se ocupassem o exíguo espaço de banco que restava, as meninas disseram que seriam aos poucos empurradas para fora pelos meninos. Ciente de que os meninos ouviram o diálogo, a segurança pediu-lhes, com voz calma e professoral, que se realocassem e deixassem mais espaço para acomodação das meninas. Impossibilitados de ignorar a reclamação, os dois adolescentes colaboraram o mínimo possível, e as meninas contentaram-se em acomodar três ou quatro colegas sentadas, de modo a fechar uma roda com as demais, que continuaram em pé. ${ }^{101}$

Fica evidente que a área reduzida de banco tende a gerar disputas por espaço entre alunos e alunas, mas também é importante ressaltar que a escassez de espaços internos no CEU facilita abordagens da equipe de seguranças. Ela consegue cobrir todo o centro educacional ao distribuirse em três pontos fixos: guarita do acesso principal, cruzamento das ruas internas e entrada do bloco esportivo-cultural. Com isso, liberam-se outros dois ou três seguranças para transitar conforme as necessidades. ${ }^{102}$

O exemplo citado nos diz algo além, que não tem relação com a influência de contextos. $\mathrm{Na}$ intervenção da segurança aparece um interesse explícito em atuar na educação dos alunos, facilitando a construção de acordos entre eles. Isso parece se relacionar de forma mais ou menos direta com o estilo de gestão de Cláudio Ferreira, que esteve à frente do centro educacional durante a quase totalidade de sua história. Ele relata ter organizado cursos "de excelência de atendimento ao cidadão", que consistiram em alguns encontros entre funcionários da gestão, da limpeza e da segurança. Nesses encontros, foram empregadas técnicas do psicodrama para reconstruir conflitos com usuários, de modo a lançar uma reflexão sobre a melhor forma de lidar com eles. Como resultado, os funcionários teriam adquirido "toda uma forma de abordagem", de modo que, ao encontrarem conflitos ou mesmo brigas, eles "deixam de atuar como profissionais

\footnotetext{
${ }^{101}$ O episódio foi presenciado por mim em 06/09/2013. Outros bancos podem ser encontrados na rua interna do CEU, mas o banco de concreto disputado neste evento é único: possui uma superfície plana e larga que amplia as possibilidades de posturas corporais.

${ }^{102}$ No CEU Butantã, em contraste, os alunos das escolas dispersam-se rapidamente pelos amplos espaços de circulação, e quando permanecem no CEU por mais tempo, a grande quantidade de bancos não dá motivos para disputas por espaço. Nesse sentido, as relações restringem-se àquelas que as pessoas desejam efetivar. Além disso, os bancos estão tão distantes dos trajetos das pessoas que aqueles que desejam sentar-se veem-se alijados das possibilidades de interação, mesmo que esta não fosse sua intenção - nesse sentido, as áreas onde estão os bancos, naquele CEU, podem se constituir como contextos separadores. A equipe de seguranças também submete-se a separações, porque, sendo de um tamanho equivalente à do CEU Vila Rubi, precisa cobrir um número maior de pontos fixos - P1, P6 e as entradas do bloco cultural, da creche e das demais escolas. Desta forma, não é possível aos seguranças transitar pelo interior do CEU, e quando isto se faz imprescindível, é preciso deixar portarias descobertas. Diga-se de passagem, a necessidade de ampliação da equipe de seguranças vem sendo apontada há vários anos no CEU Butantã, sem que o assunto receba atenção das instâncias superiores de governo.
} 
e passam a atuar como cidadãos". ${ }^{103}$ No CEU Butantã, observamos algumas situações em que vínculos empregatícios dos seguranças atuavam como intensividades mínimas, a partir das quais esses funcionários restringiam sua atuação apenas ao estipulado em contrato. Por outro lado, a fala desse gestor do CEU Vila Rubi alude a uma expansão das atribuições dos seguranças, que passam a atuar mais frequentemente como educadores. Isso aponta para o que chamaremos de intercambialidade de papéis existente entre funcionários, e mesmo entre estes e os usuários.

Se a intercambialidade de papéis acontece em função da promoção explícita do acolhimento, ela parece se combinar bem com a intensividade espacial. Para esclarecer o ponto é preciso observar que as ruas do centro educacional não funcionam apenas como passagem obrigatória de funcionários e usuários, mas também como espaços de permanência regular dos alunos das escolas, novamente por motivos em parte relacionados à falta de espaço, neste caso no interior das unidades educacionais. Uma vez que o refeitório, a cozinha e o pátio do interior da EMEF foram considerados pequenos e inadequados à utilização, ${ }^{104}$ os alunos desta unidade educacional passaram a alimentar-se no refeitório central do CEU e a utilizar as ruas internas do centro educacional durante os recreios, além de permanecerem nelas por algum tempo, após o término das aulas. Além disso, alunos do CEI saem de sua unidade escolar algumas vezes por semana para realizar atividades na piscina, na biblioteca e em outros lugares do CEU. E, desde 2011, os alunos da EMEI utilizam regularmente um parquinho construído nos fundos do centro educacional, depois que o único parquinho disponível ao CEI e à EMEI, localizado no interior do edifício que abriga as duas escolas, foi considerado insuficiente para atender a demanda - em breve abordaremos com mais detalhes essa mudança de parquinhos. Por ora é importante observar que a saída regular de alunos do interior do espaço escolar faz com que as ruas internas do CEU funcionem como uma combinação de ambiente escolar e ambiente aberto ao público em geral, misturando frequentadores assíduos e eventuais, educadores e funcionários da gestão, da segurança, entre outros. Em diversas ocasiões observei inspetores e assistentes de direção da EMEF tomando conta de seus alunos nas ruas internas do CEU. Por outro lado, havia funcionários da gestão que ajudavam a cuidar não apenas dos alunos dos cursos da gestão, mas

\footnotetext{
${ }^{103}$ Conforme relatos prestados a mim, por parte de Cláudio, em 22/03/2012 e 23/11/2012. O comportamento dos funcionários do CEU não é tão uniforme e positivo quanto aparece no depoimento do gestor, mas parece tributário de sua influência. Em minhas visitas ao centro educacional, quase sempre tive uma sensação de que os seguranças comportavam-se de modo amistoso e ao mesmo tempo alerta para comigo - muito mais do que no CEU Butantã.

${ }^{104}$ Conforme depoimento de um assistente da direção da EMEF, em 13/09/2013. O funcionário também aponta o piso liso - e escorregadio - do pátio interno da EMEF como motivo para trazer os recreios ao exterior da escola.
} 
também das escolas. Nesse sentido, a predominância de uma disposição em direção ao acolhimento encontra-se acelerada pela existência de uma intensividade espacial que obriga profissionais diferentes a atuarem no sentido de prestarem ajudas mútuas.

Nos fatos acima expostos observamos interações direcionadas ao mútuo entendimento e à intercambialidade de papéis que, por estarem inseridas em intensividades espaciais, encontramse, por assim dizer, aceleradas. Um último ponto relaciona intensividade e promoção do acolhimento, e pode ser explicitado com a história que deu origem à construção do supracitado parquinho da EMEI, nos fundos do centro educacional. ${ }^{105}$ Antes de 2011, EMEI e CEI encontraram uma forma de compartilhar a única área de lazer externa disponível no espaço edificado dessas duas unidades educacionais. Para que o revezamento ocorresse, foi necessário que o refeitório do CEI recuasse para uma área alargada de corredor interno ${ }^{106}$, visto que originalmente ocupava a parte coberta da área de lazer. No entanto, ao assumir a direção do CEI em 2011, a educadora Tânia Sampaio achou por bem resgatar o espaço original do refeitório e instalar toldos para proteger da chuva as mesas realocadas. Essa mudança trouxe obstáculos físicos para o acesso da EMEI a uma área que, ainda por cima, foi significativamente reduzida. $^{107}$

Na avaliação da então coordenadora pedagógica do CEI, Daniela Oliveira, este "problema concreto" esteve na origem de "problemas imaginários" surgidos entre professoras das duas escolas, que levaram o assunto "para o [âmbito] pessoal". Desconfortos mútuos se acumularam, até que, durante uma reunião pedagógica para discutir assuntos do $\mathrm{CEU}$, as coordenadoras pedagógicas das duas escolas se encontraram e organizaram uma reunião "supertensa", "simbólica", que contou com a presença da maior parte das professoras. No encontro houve brigas e discussões sobre desentendimentos guardados há muito tempo, e que não eram necessariamente graves. Por exemplo, uma professora acusou outra de não a ter cumprimentado em certo dia quando chegava à escola, e recebeu a réplica de que isso teria ocorrido porque a acusada estava atrasada. Ao final, com a "roupa suja" lavada, diversos mal-entendidos foram

\footnotetext{
${ }^{105} \mathrm{O}$ parquinho foi construído entre 2011 e 2012. O relato a seguir tem como base os depoimentos prestados a mim pela ex-coordenadora pedagógica do CEI, Daniela Oliveira, em 23/11/2012 e 13/09/2013, e pela diretora da mesma instituição, Tânia Sampaio, em 06/09/2013.

${ }^{106}$ Esta área de corredor mais larga pode ser observada na figura 13 do primeiro capítulo.

${ }^{107}$ Graças ao revezamento proporcionado por contextos separadores de âmbito espacial e temporal: quando alunos da EMEI desciam do primeiro andar para usar a área, alunos do CEI eram fechados no espaço do corredor interno à sua escola, que também abrigava as mesas do refeitório; quando alunos do CEI ocupavam a área, a escada que dava acesso à EMEI era fechada. Os fluxos podem ser vislumbrados na figura 13. Este é mais um exemplo em que adiantamos a hipótese de que as separações funcionam como articuladoras da intensividade.
} 
esclarecidos, tendo sido redigido um documento que estabelecia regras de conduta e reciprocidade. A partir de então foi possível voltar ao "problema concreto" da falta de espaço, decidindo-se pela construção de um parquinho para a EMEI, nos fundos do CEU.

Este exemplo mostra que a intensividade espacial obrigou educadoras das duas escolas a interagir. Se o contexto intensivo do parquinho está na origem de conflitos e de "problemas imaginários", ele também presidiu a sua solução, na medida em que as professoras precisaram conversar para dar conta de um "problema concreto". Desfizeram-se assim os "problemas imaginários", que aqui podem ser facilmente aproximados ao que chamamos anteriormente de essencializações (HERZFELD, 2008), ou identidades pessoais homogêneas. A análise da excoordenadora pedagógica Daniela Oliveira ajuda a ilustrar a dinâmica desses processos identitários, na medida em que ela conclui o relato acima com a recomendação de esclarecer "problemas concretos" "no começo, porque se não a coisa vira uma outra coisa e não dá mais pra resolver".

No entanto, quando há intensividade e os conflitos não se resolvem, a tensão cotidiana pode ser muito maior que a de contextos extensivos, já que as interações são inevitáveis. Uma forma de controlar ou articular esses conflitos pode acontecer com a implementação de separações, como veremos num tópico seguinte. Podemos supor outra forma, no entanto, que difere do modo pelo qual o conflito de parquinhos parece ter sido resolvido. Quando as interações são obrigatórias, é de se imaginar que haja desconfianças mútuas quanto ao propósito que leva as pessoas a se sentarem numa mesa de negociação. Nestes casos, os acordos gerados podem estabelecer-se num nível superficial, escondendo diferenças mais profundas que não chegam a ser trabalhadas, permanecendo os desconfortos. Esta hipótese fica mais plausível se resgatarmos a análise da construção do palco na pista de skate do CEU Butantã. Naquele caso, o sucesso da iniciativa do gestor parecia relacionar-se com o pressuposto de que a aproximação do coordenador cultural era voluntária - já que, sendo presidida pela extensividade, poderia perfeitamente ter sido evitada.

A história da pista de skate no CEU Butantã e o conflito de parquinhos no CEU Vila Rubi exemplificam situações bem-sucedidas de construção de diálogo e mútuo entendimento - no primeiro caso presididas por extensividades e no segundo, por intensividades. Mas, se as extensividades podem contribuir com afastamentos, confusões de sentido e estigmatizações interpessoais estabilizadas, as intensividades podem acirrar conflitos existentes e lançar dúvida 
quanto à motivação das pessoas para interagir, de modo que as estigmatizações interpessoais continuem sendo alimentadas. Fica claro, assim, que ambos os contextos podem estar envolvidos em efeitos desejáveis e indesejáveis, ainda que produzam diferentes arcos de possibilidades de ação e interação. A existência de certo contexto não leva necessariamente à produção de consensos ou conflitos, nem incentiva as pessoas a mudanças de valores e preferências, incluindo-se aí a predisposição ao acolhimento. Os contextos funcionam como "regras do jogo" para as interações: não dizem nada sobre o resultado de cada partida, mas não podem ser ignorados pelos jogadores.

\subsubsection{Separações como articuladoras da intensividade}

Podemos apontar uma situação exemplar de acirramento de conflitos em contextos intensivos ocorrida entre setembro de 2007 e o início de 2008, nos primeiros meses de história do CEU Vila Rubi. Eles foram equacionados com a chegada do gestor Cláudio Ferreira em fevereiro de 2008, em função de seu interesse na promoção do acolhimento, e com a implantação de extensividades e separações que não se opuseram da forma como vimos no CEU Butantã.

Em suas próprias palavras, Cláudio havia sido chamado para "resolver a destruição de um equipamento público", ${ }^{108}$ já que o centro educacional foi muito mal recebido por ter ocupado um campo de futebol que era a única opção de lazer das comunidades do entorno. Mas os conflitos já pareciam ditar a dinâmica política local antes da chegada do CEU, com destaque para a rivalidade entre as comunidades Iporanga e Vila Rubi, em função de filiações partidárias e de conflitos entre facções ligadas ao tráfico de drogas. Conta-se também que, ao serem solicitadas a direcionar parte de seus alunos para o CEU, as escolas do entorno enviaram os estudantes com mais problemas disciplinares, aproveitando para "fazer uma limpa". ${ }^{109}$

A intensividade, neste caso, encontra-se mesclada à extensividade, pois não se pode dizer que os moradores locais sejam induzidos a entrar no $\mathrm{CEU}$, na medida em que vivem num ambiente urbano garantidor de escolhas de circulação e interação. Mas a intensividade nunca é total, e podemos empregá-la aqui para compreender uma situação de obrigatoriedade de

\footnotetext{
${ }^{108}$ Os eventos a seguir foram relatados em entrevistas concedidas a mim por Cláudio em 22/03/2012 e 23/11/2012. A gravidade da situação foi confirmada por diversos outros relatos de usuários e funcionários.

${ }^{109} \mathrm{~A}$ alegação de recebimento dos alunos de pior comportamento das escolas do entorno quando do início do funcionamento de um CEU também apareceu no relato da ex-diretora da EMEF do CEU Butantã, bem como em outros CEUs que visitei.
} 
frequência às escolas e de inexistência de alternativas de lazer - de qualquer forma, o componente extensivo aí presente não atenuaria incertezas e inseguranças. Enfim, este quadro, somado à insatisfação gerada com a chegada do CEU, resultava em atos de vandalismo, roubos e brigas. Conforme lembra o gestor, a porta do centro educacional estava frequentemente tomada de alunos brigando com pedras, paus com prego, estiletes. A população "roubava de tudo": leite, extintor, chuveiro. Usuários entravam na piscina sem autorização e faziam do talude lateral da rua principal do CEU um escorregador, arruinando a vegetação. Outros educadores e usuários antigos lembram-se de pedras atiradas em janelas e de derramamento, nas calçadas, do leite distribuído pelas escolas. Uma usuária resgata o comentário então realizado por um grupo de garotas: "agora só falta a gente colocar fogo aqui".

Para dar conta dessa situação, uma das principais medidas tomadas pelo novo gestor foi exigir a apresentação de carteirinhas para o ingresso no centro educacional, assegurando certa regulação da circulação e das interações por meio do reforço de assimetrias de poder. A mudança suscitou reclamações, inclusive a de uma professora que considerou prejudicado o seu "direito de trabalhar"; o gestor afirmava que não estava impedindo o acesso, e sim protegendo quem estava dentro do $\mathrm{CEU}$, para que "tivessem garantias". A alegação soa familiar em relação àquela apresentada pela gestora do CEU Butantã para justificar a implantação de carteirinhas, mas no caso do CEU Vila Rubi a medida não vinha acompanhada de um histórico de práticas desfavorecedoras do acolhimento. Pelo contrário, a implantação de separações de âmbito espacial veio acompanhada da expansão de extensividades em outros âmbitos e de atividades do interesse dos moradores, como veremos no próximo tópico. O gestor convocou lideranças das comunidades para discutir os conflitos ocorridos, bem como suas possibilidades de enfrentamento, asseverando-lhes que "do portão para fora eu não posso fazer nada, mas do portão para dentro todos serão tratados como cidadãos de direito".

É muito significativo que, nesta fala, um dispositivo de controle de espaço - o portão demarque justamente a possibilidade de efetivação da "cidadania" e não o seu cerceamento, como é comum considerar. Os portões aparecem, no discurso do gestor, como garantidores de regras mínimas para um convívio respeitoso - e, portanto, como possibilitadores da vida pública, sobretudo diante da necessidade de conter frequentadores interessados em brigar, depredar e roubar o centro educacional. Já observamos no capítulo anterior que a abertura espacial é historicamente associada à possibilidade da troca e do livre trânsito, relacionando-se portanto à 
liberdade, um dos valores mais caros a nossas democracias contemporâneas. Mas nos casos em que o livre acesso possibilita a expansão de práticas nitidamente consideradas prejudiciais ao interesse público, o fechamento dos espaços pode ser visto como garantidor, e não cerceador, da liberdade.

Essa conclusão obviamente não deve ser empregada para questionar a validade de análises que criticam os fechamentos de espaço, já que estes sistematicamente envolvem apropriações indébitas e prejuízos ao interesse público. No entanto, é preciso recolocar essas análises dentro de um campo de possibilidades mais amplo, capaz de atinar para uma gama maior dos efeitos dos fechamentos de espaço. Isso fica claro quando buscamos um paralelo entre discussões de espaço e de política que garantem semelhantes assimetrias de poder e restrições à liberdade. Parece que ao discutir a atuação do Estado e a produção de contextos legais estamos mais prontos a admitir que a liberdade não é o único valor necessário a nossas democracias, pois elas não funcionariam sem proibições, compulsoriedades, e sem o inevitável reforço de certas hierarquias de poder aí implícitas. ${ }^{110}$ Mas, quando passamos do âmbito político para o espacial, condicionantes semelhantes ganham invariavelmente uma conotação negativa, mostrando haver um ponto cego em muitos dos debates que relacionam política e espaço (CALDEIRA, 2000; BERMAN, 1986; JACOBS, 1961; SENNET, 1974).

Por ora, é importante voltar a observar que o efeito político mais evidente proporcionado pelas separações é a redução da incerteza. No CEU Butantã as separações fizeram frente à livre escolha de agir e interagir proporcionada pelas extensividades. No CEU Vila Rubi, a incerteza é produzida pelas intensividades e pela consequente aceleração das dinâmicas interacionais, mas também pela presença de extensividades. Considerando-se os dois casos, extensividades e intensividades aparecem ambas como produtoras de incerteza. ${ }^{111}$ Neste sentido elas aproximamse, contrapondo-se às separações. Ao produzir intermitências ou interrupções nas interações, as separações aumentam a previsibilidade destas, e isto não é necessariamente indesejável.

No CEU Vila Rubi, os gestores não estavam interessados em maximizar a segurança e a previsibilidade, e sim em disponibilizar atividades e canais de diálogo à população. É provável que as separações tenham se atenuado com o tempo, na medida em que os frequentadores do

\footnotetext{
${ }^{110}$ Podemos resgatar aqui a associação já mencionada no capítulo anterior, entre consenso e coerção, frequente em análises do poder do Estado, como por exemplo em Tilly (1996) e Gramsci (1980).

${ }^{111}$ Resgatando uma observação do capítulo anterior, podemos diferenciar as incertezas e liberdades trazidas pelos dois contextos: sob a intensividade não sabemos como se darão as interações; sob as extensividades não sabemos sequer se elas acontecerão, já que a sua própria efetivação depende da intenção das pessoas.
} 
centro educacional passaram a rever suas atitudes. Isso explicaria a forma branda do controle de acesso que observei ser realizado em minhas visitas. O portão principal do centro educacional estava quase sempre encostado ou entreaberto, e para atravessá-lo bastava um aceno a guardas que não me conheciam. Apenas em duas das primeiras visitas fui indagado sobre o meu destino, e numa outra ocasião minha chegada à gestão foi anunciada via rádio pelos seguranças. Tanto no portão quanto no interior do equipamento as atitudes desses profissionais me transmitiam impressões simultâneas de monitoramento e transigência. ${ }^{112}$

A diminuição progressiva das separações mostra que os gestores deste centro educacional não só pensaram em combinar contextos num dado momento, como também trabalharam com variações nesta combinação ao longo do tempo. Trata-se de um modo muito diferente de operar com contextos em relação ao que observamos no CEU Butantã: naquele caso, os dispositivos legais e espaciais implementados pelos projetos políticos e arquitetônicos, bem como o estilo de gestão dos primeiros anos, não só procuraram maximizar as extensividades, como esta maximização foi implementada de imediato. Com isso, produziu-se uma quantidade considerável e ao mesmo tempo repentina de incerteza. No CEU Vila Rubi, a extensividade também foi favorecida, mas não de modo exclusivo, e o seu predomínio parece ter-se configurado aos poucos, na medida em que as separações foram sendo diminuídas. Podemos imaginar que um aumento paulatino de extensividades traz incrementos sucessivos de incerteza que são certamente mais fáceis de serem manejados. Da forma como foi feita, a entrega progressiva de liberdades parece ter favorecido a construção gradativa de respeito e mútuo entendimento entre funcionários e usuários. Desse modo, quando as separações se reduziram, a incerteza já não tomava a forma de insegurança ou de exposição excessiva ao risco. Ela continuava existindo, mas as pessoas já não estavam interessadas em fazer uso de sua liberdade num sentido nocivo ao centro educacional. Estas observações serão importantes para certas reflexões na conclusão da pesquisa.

Na verdade, a possibilidade de haver conflitos, depredações e outras situações indesejáveis continuava existindo. Mas era uma possibilidade menor, que parecia envolver usuários que não frequentavam regularmente o centro educacional e não estavam habituados aos códigos de reciprocidade construídos. Brigas e outros conflitos ainda eram registrados com certa frequência

\footnotetext{
${ }^{112}$ Vale lembrar que os seguranças teriam passado por um "curso de excelência no atendimento aos cidadãos", conforme observamos no item anterior.
} 
até 2010, mas pareciam ocorrer numa proporção gradativamente menor, e raramente envolviam a depredação das instalações e espaços do centro educacional. ${ }^{113}$ Mesmo assim pude presenciar casos isolados, como o da depredação do cenário de uma atração oferecida durante a Virada Cultural de 2012 (ocorrida em 04/05/2012). Na ocasião conversei com uma funcionária da gestão, que atribuiu a ação a jovens que não moravam nas proximidades do CEU - os quais, portanto, não tinham participado das construções gradativas de mútuo entendimento. Em vez de citar a ocorrência como motivo para ampliar separações, a funcionária entendeu-a como parte constitutiva do seu cotidiano, na medida em que o CEU exigia "trabalho de formiguinha" para ir construindo, dia após dia, acordos entre as pessoas. A expressão "trabalho de formiguinha", que ouvi em mais de uma ocasião neste CEU, é interessante justamente por entender a construção de diálogo como um processo longo e paulatino, mas nem por isso pouco efetivo.

Mesmo os controles e fechamentos de espaço que continuaram existindo adquirem significados muito diversos conforme os gestos, a entonação de voz e o comportamento daqueles responsáveis pelo seu manejo. Além desta variação qualitativa de significados, há também as quantitativas: as separações podem ser aplicadas ou estritamente, ou de um modo mais brando e gradual. Um exemplo de aplicação gradual de controle de acesso é o da permissão de entrada de usuários que relutavam em fazer suas carteirinhas, presumivelmente por serem procurados pela polícia: nestes casos, os seguranças pactuavam que amigos com carteirinha ficariam responsáveis pelos atos alheios. ${ }^{114}$ Vê-se que, surpreendentemente, a modulação das separações demanda uma triagem e uma negociação entre funcionários e usuários, motivando certas interações, ao invés de cerceá-las da forma como geralmente se supõe. Assim, se no item anterior o contato entre seguranças e usuários era induzido pelas exiguidades de espaço, precisamos considerar também o incremento de contatos proporcionado pelas interações em torno dos portões. ${ }^{115}$

Além de atuarem nas entradas do centro educacional, as separações também foram empregadas em seus espaços internos. Parece que a preponderância de contextos intensivos de âmbito espacial produz uma concentração de interações que exige, até certo ponto, a implementação de separações capazes de regulá-las, organizá-las e articulá-las. Os relatos do

\footnotetext{
${ }^{113}$ A diminuição gradativa de conflitos foi relatada a mim numa conversa de 02/05/2013 com Viviane Ramos, coordenadora do Núcleo de Ação Cultural, que esteve no cargo durante quase toda a gestão de Cláudio Ferreira.

${ }^{114}$ De acordo com relato de um funcionário da gestão feito em 22/03/2012.

${ }^{115}$ Em contraposição, os acessos desimpedidos do CEU Butantã faziam dos seguranças uma categoria de profissionais muito mais distanciada dos usuários.
} 
item anterior podem nos ajudar a ilustrar este ponto. No exemplo da disputa pelo espaço do banco, alunas estipulavam um esboço - não efetivado - de regra produtora de separações ao defender o revezamento do banco. Já o caso do compartilhamento dos parquinhos entre EMEI e CEI envolve revezamentos efetivados por contextos separadores de âmbito temporal - alunos de uma escola não ocupavam o parquinho enquanto os da outra estavam presentes. No entanto, esses contextos não foram suficientes para contornar as dificuldades trazidas pela intensividade espacial - o refeitório do CEI não pôde mais configurar-se no espaço de corredor interno e precisou tomar o pátio, dificultando o acesso da EMEI. Assim, substituiu-se a solução da separação temporal por uma extensividade espacial, representada pela construção de um parquinho exclusivo para a EMEI.

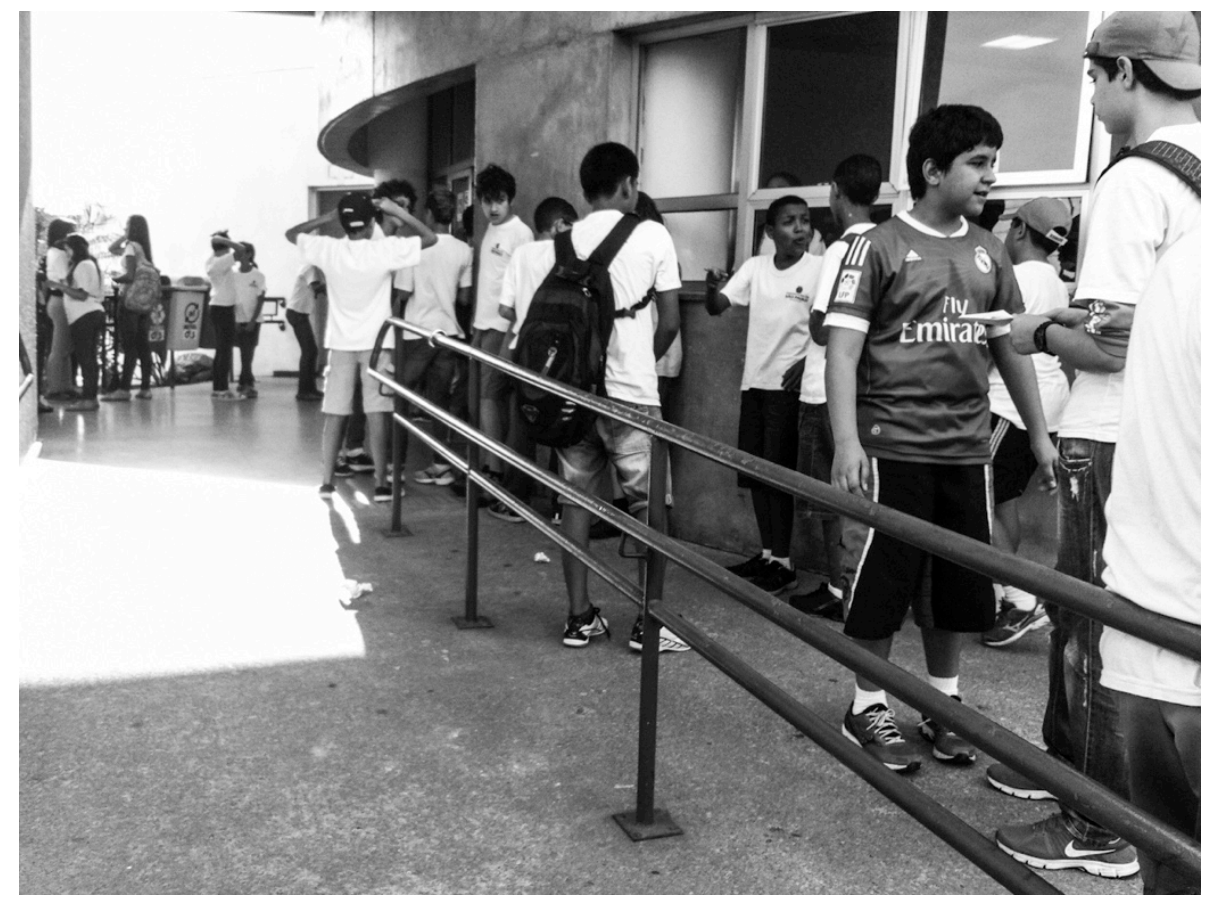

Figura 37 - Fila para entrada no refeitório do CEU Vila Rubi.

Em outros casos, dispositivos separadores estão mais consolidados. Eles são fundamentais para regular a afluência ao refeitório central, que serve a uma grande quantidade de alunos provenientes da EMEF e dos cursos oferecidos pela gestão. Em primeiro lugar, há contextos separadores de âmbito temporal que definem horários diferentes para as refeições de cada turma. Além disso, enquanto o refeitório termina de ser limpo e esvaziado, alunos à espera das refeições formam filas no espaço de circulação que precede a porta de entrada do refeitório, configuradora 
de uma separação espacial. A necessidade de controlar este e diversos outros fluxos de estudantes intensifica o contato entre eles e funcionários da gestão, reforçando o incentivo a interações produzido por separações, como acabamos de observar ao analisar o portão de entrada do centro educacional. Esse trabalho de controle do fluxo de alunos é desempenhado com destaque pelo assistente técnico de ensino Luís Prates, vinculado ao Núcleo de Ação Educacional da gestão. Luís conhece incontáveis crianças pelo nome, acompanha com atenção o estado de saúde de algumas delas, distribui conselhos e cobra, com humor e disposição, comparecimentos a aulas e outras atividades dos alunos. ${ }^{116}$ Organizando deslocamentos pelo interior do CEU, o assistente manifesta uma disposição singular para com o acolhimento, ao mesmo tempo que garante a observância de separações de âmbito temporal e espacial. Por vezes, Luís Prates auxilia ou é auxiliado por funcionários de outros equipamentos, principalmente da EMEF, dando conta da intercambialidade de papéis presente também em torno deste tipo de contexto.

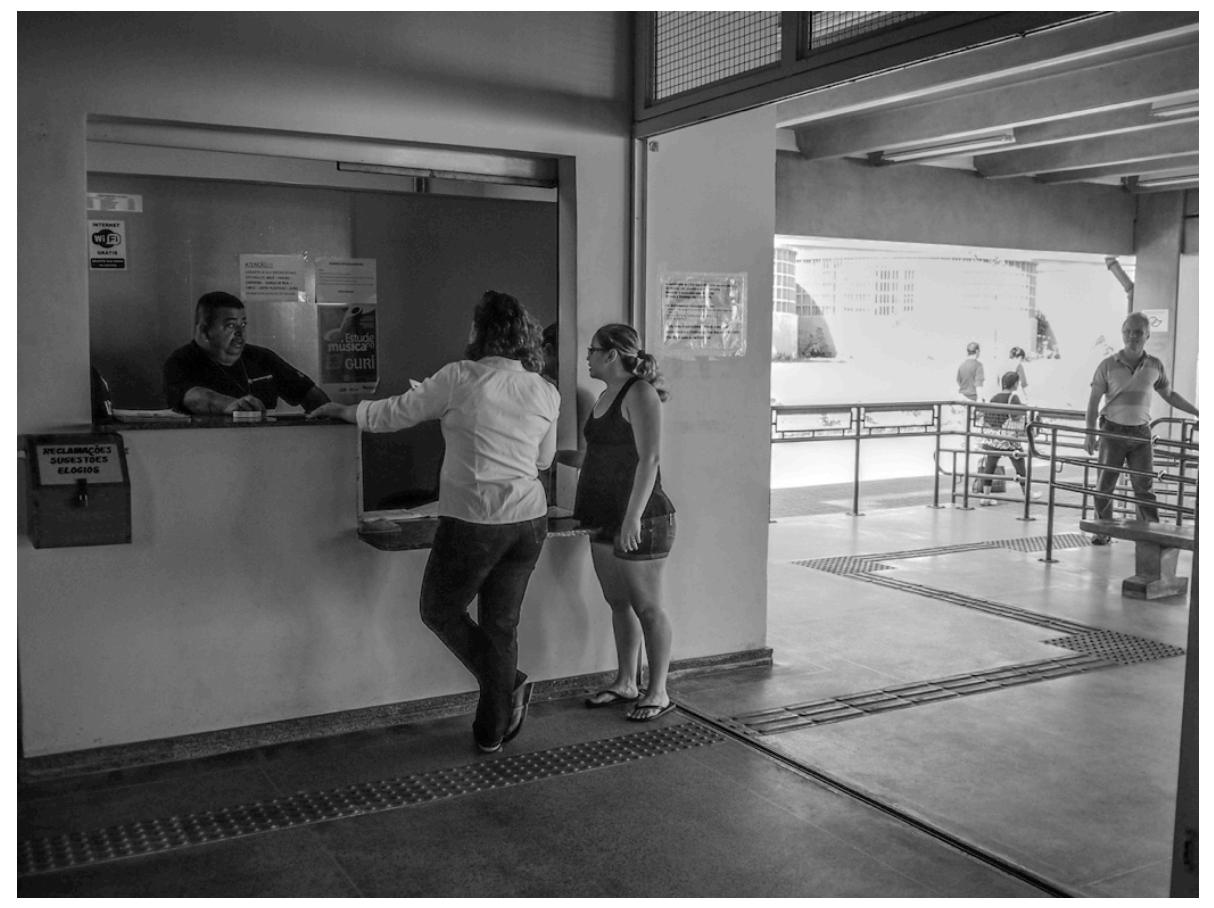

Figura 38 - Guichê de atendimento no térreo do edifício da gestão do CEU Vila Rubi, com Luís

\footnotetext{
${ }^{116} \mathrm{O}$ trabalho de Luís Prates é impensável para os assistentes da gestão do CEU Butantã, que praticamente só desempenham atividades nos escritórios do terceiro piso do bloco cultural, sem ter qualquer contato com alunos das distantes escolas do bloco educacional. Mesmo os inspetores de ensino da EMEF daquele CEU pareciam adotar tímidas disposições em conter e negociar as condutas dos alunos. Nos frequentes casos de indisciplina, a diretora da EMEF costumava intervir em pessoa.
} 


\section{Prates realizando o atendimento. À direita da imagem, o gestor Cláudio Ferreira.}

Um último exemplo de separações articuladoras e organizadoras da intensividade refere-se ao funcionamento dos escritórios da própria gestão. Originalmente, a gestão concentrava todos os tipos de atendimento à população no primeiro andar de seu edifício, de modo que o térreo contava com uma área livre coberta acessível ao público, além de uma central de de segurança e das áreas de chegada do elevador e da escada. ${ }^{117}$ Conforme o relato do gestor Cláudio Ferreira, isso trazia um grande contingente de usuários ao primeiro andar, atrapalhando a rotina dos escritórios. A intensividade, no caso, foi resolvida com a transformação da área ocupada pela central de segurança no térreo em um guichê de atendimento. Num local de acesso facilitado, o guichê passou a realizar a maior parte dos atendimentos - geralmente solicitações de esclarecimento e inscrição em cursos promovidos pela gestão. Ao mesmo tempo, o funcionário do guichê passou a realizar uma triagem das pessoas que desejavam subir ao primeiro andar, onde ocorriam outros tipos de interação. ${ }^{118}$

Um último efeito importante das separações para a política das interações cotidianas refere-se aos reforços de poder, autonomia, privacidade, e mesmo da própria subjetividade daqueles que, por meio delas, podem contar com um território ou um domínio para chamar de próprio. No início da história do CEU Vila Rubi, as separações espaciais garantiram à gestão um reforço de sua identidade institucional e de seu poder propriamente dito, de forma semelhante aos efeitos produzidos pelas separações legais implantadas a partir de 2005 pelos gestores do CEU Butantã. Um exemplo mais significativo será observado na análise da biblioteca do CEU Butantã, no próximo capítulo. ${ }^{119}$

\footnotetext{
${ }^{117}$ A figura 16, no primeiro capítulo, representa estes espaços internos da gestão.

${ }^{118}$ Por outro lado, no CEU Butantã, pessoas interessadas em falar com a gestão precisam subir três andares, e antes disso precisam encontrar as escadas - tarefa nem sempre fácil, já que elas se encontram longe do fluxo de circulação principal, na parte posterior do bloco cultural (conforme indicado na figura 25). No terceiro andar, o usuário encontra escritórios quase totalmente fechados por divisórias, com exceção de um guichê de atendimento que fica quase sempre desguarnecido de funcionários e que oferece um ângulo de visão limitado dos espaços administrativos internos. As divisórias foram implementadas durante as gestões que se sucederam entre 2005 e 2012.

${ }^{119}$ Um exemplo singelo de como as separações espaciais podem servir à produção de autonomia está na reflexão realizada por algumas educadoras numa discussão de que participei para reforma do parquinho do CEI, no CEU Butantã (dentre outras ocasiões, em 02/09/2013). Elas recomendaram que houvesse espaços em que as crianças pudessem se sentir escondidas dos adultos, para atenuar o incômodo de serem constantemente observadas. Observei a escolha de crianças por brincar em cantos e recessos que fogem ao olhar dos adultos em diversas ocasiões, inclusive entre alunos da EMEI do CEU Vila Rubi, em 20/09/2013. Um ponto culminante de produção de separações poderia estar na atitude de uma criança em fechar os olhos diante de adultos em relação aos quais sentese envergonhada - quando isso aconteceu comigo, a diretora do CEI do CEU Butantã, Patrícia Takada, comentou
} 
Até este momento observamos como a política cotidiana do CEU Vila Rubi amparou-se na atuação conjunta e em certo sentido complementar dos dois tipos de contexto produtores de dinâmicas interacionais não voluntárias. Enquanto as intensividades forçam as pessoas a estabelecer contatos, as separações atuam em sentido oposto, impondo rupturas e intermitências nesses contatos. Contextos separadores produzem compensações das acelerações de interações e tensões produzidas por contextos intensivos. No próximo tópico observaremos como as extensividades inserem-se nesta dinâmica.

\subsubsection{Predomínio de extensividades}

Como já observamos, as atividades políticas, culturais e educacionais promovidas por uma gestão de CEU são de frequência voluntária, à diferença do que acontece em outros equipamentos educacionais. Procuraremos mostrar que no CEU Vila Rubi esses contextos extensivos foram promovidos de modo indissociável em relação aos outros. Ao final, vamos relacionar a desenvoltura dos gestores na promoção das extensividades a suas trajetórias profissionais pregressas, ligadas à arte e à produção cultural. Assim, torna-se possível marcar algumas diferenças fundamentais entre centros educacionais e escolas em geral.

No CEU Vila Rubi as separações foram empregadas no sentido de garantir a segurança e a organização, afastando-se do sentido de exclusão que adquiriram no CEU Butantã. No entanto, para que conseguissem atenuar as intensividades e conflitos do início da história do centro educacional, as separações precisaram contar não apenas com uma especificação mais favorável de seus significados, mas também com o reforço proporcionado pelas extensividades. A relação entre os dois contextos fica evidente quando o gestor Cláudio Ferreira se refere, por um lado, à suposta necessidade de controlar a entrada de frequentadores ligados ao hip-hop - revistando "até mochilas" - e, por outro, faz a ressalva de que "a coisa só começou a funcionar" quando implantou o conselho cultural - ou seja, quando estabeleceu uma instância política participativa e extensiva, analisada mais adiante. ${ }^{120}$ Submetendo-se a contextos separadores, os frequentadores do centro educacional encontraram espaços, cursos e canais de diálogo ao seu dispor. Assim, se os âmbitos espacial, temporal e legal estavam pontuados por separações e intensividades - ou

que muitas crianças fecham os olhos para "fazer desaparecer os adultos". Em nossos termos, essa seria uma forma simples de produzir contextos separadores.

${ }^{120}$ Conforme depoimento prestado a mim por Cláudio, em 23/11/2012. 
seja, por interações de tipo não voluntário -, os âmbitos político, educacional e cultural caracterizavam-se por uma extensividade amenizadora da conotação negativa dos outros tipos de contexto. Constituiu-se, assim, uma calibragem nova entre assimetrias e simetrias de poder que terminaram por conquistar os favores de grande parte dos frequentadores do centro educacional, facilitando a efetivação do acolhimento.

Já mencionamos a iniciativa do gestor em travar um diálogo com lideranças comunitárias, em função de conflitos, depredações e roubos que assolaram o início da história deste centro educacional. Acrescentamos, agora, que a conotação dessa conversa não se relacionava apenas à justificação de medidas de segurança. O gestor também declarou às lideranças: "estou aqui para servi-los"; disse ainda que "tinha muito orgulho disso", mas que, em contrapartida, o CEU, como "espaço público", tinha um custo, não era gratuito, precisava ser respeitado. Dava início, assim, ao que chama de "apropriação e pertencimento responsável", que teria continuidade com a promoção de conselhos e festas. Mas a simples tentativa de travar acordos mais horizontais com as comunidades já surtiu efeitos positivos. É possível dizer que parte do sucesso da aproximação do gestor deve-se a um fator já observado quando analisamos a interação, ocorrida no CEU Butantã, entre o coordenador de cultura Caio Uehbe e os usuários da pista de skate: quando não há medidas compulsórias determinando uma aproximação, ela tende a ser vista como derivada da livre e espontânea vontade daquele que a iniciou, suscitando respostas favoráveis daqueles assim procurados. Em sentido oposto podemos supor que, em contextos intensivos, a obrigatoriedade das interações tende a lançar uma parcela de desconfiança mesmo sobre as que se revestem de um ar de sinceridade. ${ }^{121}$

O melhor exemplo de como o gestor passou a contar com a colaboração das comunidades também dá conta do poder de organização interna delas. Ao comunicar às lideranças comunitárias o roubo de um sifão do lavatório do banheiro do bloco esportivo-cultural, elas identificaram os jovens responsáveis pelo ocorrido, recompraram a peça do ferro-velho para o qual havia sido vendida e a reinstalaram. ${ }^{122}$

\footnotetext{
${ }^{121}$ Com isso não devemos supor que essa parcela de desconfiança não possa variar significativamente, e que contextos intensivos não possam presidir interações entre pessoas mutuamente dispostas umas para com as outras. O contexto é outro, e com ele mudam os referenciais de conduta e interação, mas o desenrolar dos acontecimentos não é previsível.

${ }^{122}$ Raciocínio semelhante ao do gestor deste centro educacional foi desenvolvido pela liderança comunitária Fernanda Alvez, para contrastar possibilidades de atitude da gestão no CEU Butantã: "Só que como eu posso fazer para que eu evite situações de constrangimento dentro do equipamento? Eu tenho um contato direto com essa comunidade. Eu falar 'ó, essa piscina aqui não é minha, essa piscina aqui é de vocês, então tem que cuidar.' [...] Os
} 


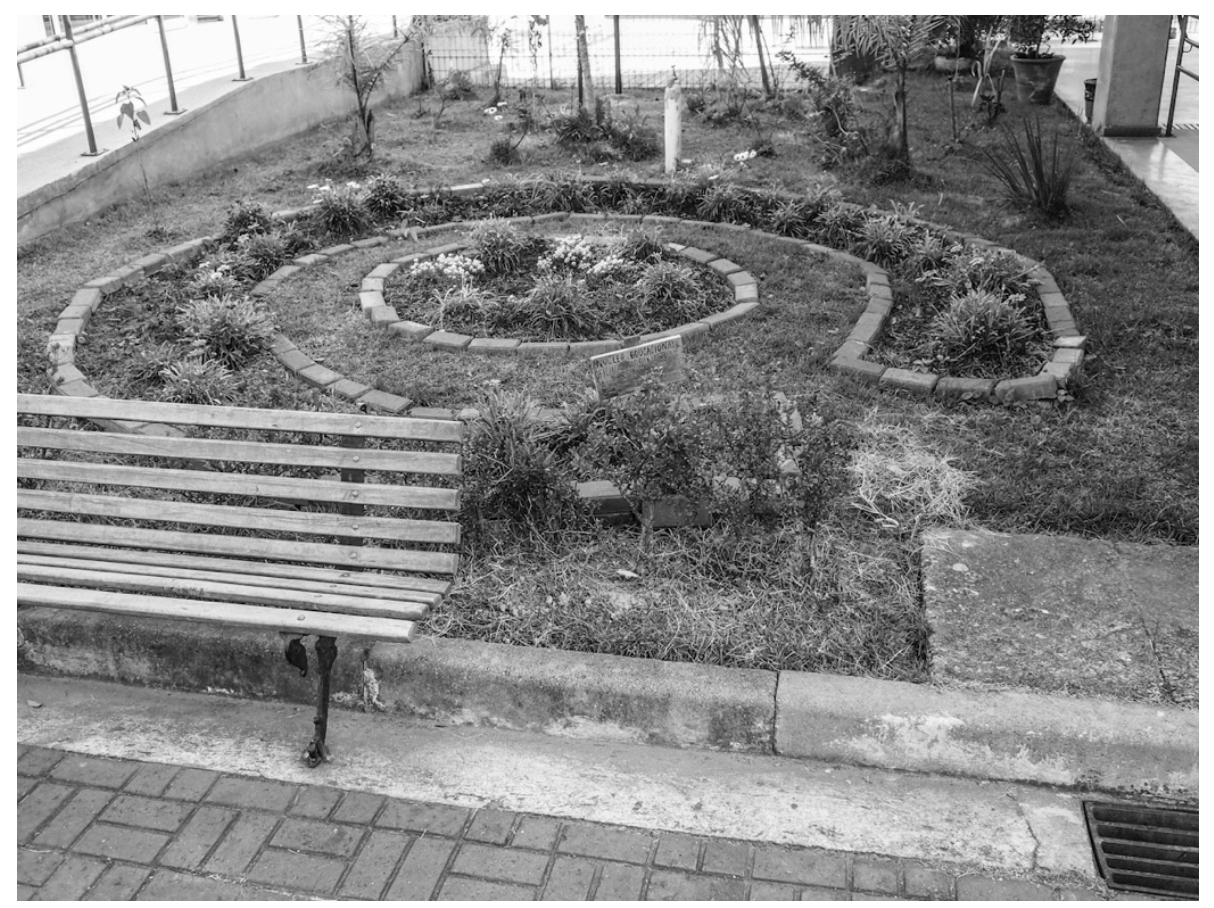

Figura 39 - Canteiro cultivado pelos alunos do CEU Vila Rubi, em cursos de jardinagem.

Já aludimos a uma intercambialidade de papéis entre seguranças e educadores quando analisamos as intensividades; podemos observar agora como ela pode acontecer também entre usuários e seguranças. Nas palavras de Viviane Ramos, coordenadora do Núcleo de Ação Cultural durante a gestão de Cláudio Ferreira, fica claro que este processo não se vincula apenas ao âmbito político, mas também a outras atividades de cunho voluntário, representadas, por exemplo, por cursos de jardinagem oferecidos a crianças. Segundo ela, ao cultivar canteiros na rua interna do centro educacional, as crianças "sentem que o jardim é produzido por elas" e passam a repreender tentativas de depredação. Interpretando o ponto de vista desses usuários, a coordenadora estipula: "quando eu fiz, vou cuidar para que nada aconteça". Isto constituiria, no seu entender, um "empoderamento" ${ }^{123}$ da população. Enfim, seguindo as palavras da

skatistas, é chamar e falar 'ó, está acontecendo isso e isso, será que tem como vocês resolverem?'. Eu não preciso me confrontar com a comunidade, porque o meu interesse não é me confrontar, mas me unir com ela. Você entendeu? Porque uma vez que eu me uno com ela pode ter certeza que não vai acontecer nada dentro desse equipamento, porque a própria comunidade vai proteger aquilo que é dela. Isso é uma coisa automática que vai acontecer. Agora, a partir do momento que a comunidade se sente excluída, vai acontecer da comunidade querer passar lá na frente, não vai deixar, aí vai estourar isso, vai quebrar aquilo. Aí vai ser dado como vandalismo, mas se você for pensar tem uma certa coerência. Não que eu esteja concordando, mas tem uma certa coerência."

${ }^{123} \mathrm{O}$ termo "empoderamento" também é utilizado pela educadora Anna Cecília Simões, tanto para explicar seu modo de interação com a população como para qualificar positivamente aqueles casos em que usuários apropriavam-se indevidamente dos espaços e recursos do CEU Butantã, como se isso fosse um primeiro passo em 
coordenadora, "quando invertem-se os papéis, a coisa muda".

Vemos que, se esta intercambialidade de papéis pode ser incentivada pela cooperação exigida por interações aceleradas, ela também parece acontecer sob a extensividade, e de modo mais efetivo, pois se insere numa economia de trocas mais ampla, envolvendo sentimentos e disposições voluntárias das pessoas. A intercambialidade também existiria em sentido oposto quando funcionários consideram-se também usuários -, na medida em que muitos funcionários da limpeza, da segurança e mesmo da gestão seriam moradores das proximidades do centro educacional, e muitos teriam filhos matriculados em suas escolas. ${ }^{124}$

Parece necessário, neste momento, pormenorizar de forma mais precisa a ampliação das extensividades da gestão. Em primeiro lugar houve uma oficialização de canais de participação. O conselho gestor reunia frequentadores internos ao CEU e representantes de organizações do entorno urbano, mas o centro educacional passou a contar com outros conselhos, especializados em discutir assuntos relativos a cada um dos núcleos da gestão. Criaram-se assim os conselhos cultural, esportivo, educacional e estudantil - o penúltimo reunindo pais e educadores, e o último, alunos das escolas, de modo que ambos vinculavam-se ao Núcleo Educacional. Era de se esperar que a vinculação a diferentes funcionários e públicos trouxesse afluências muito desiguais às reuniões: indícios apontam para um desenvolvimento incipiente dos últimos dois conselhos, enquanto o cultural teria adquirido maior proeminência, até mesmo em virtude de afinidades e preferências do próprio gestor, conforme observaremos mais adiante.

Grande parte dos motivos que atraíam pessoas aos conselhos relacionava-se à oportunidade de discutir assuntos de seu imediato interesse, desobrigando-as da participação em discussões mais gerais do CEU. Artistas precisavam reunir-se no conselho cultural para organizar apresentações no teatro, para promover cursos e outros tipos de atividade. Esportistas planejavam participações em campeonatos e sobretudo agendavam ocupações das quadras

direção a uma apropriação responsável. Conforme o relato prestado a mim pela bibliotecária Regina Ferreira em 26/11/2012.

${ }^{124}$ Há vários outros sinais de intercambialidade de papéis. Júlia Ferreira, moradora da Vila Rubi e mãe de alunos do CEU, é uma ativa cooperadora da gestão, destacando-se sua atuação como organizadora das barracas de alimentação e artesanato nas festas promovidas pelo CEU, conforme veremos adiante. Assistentes técnicos de ensino da gestão dispõem-se a realizar pequenos reparos e construções pelo CEU, assumindo tarefas nitidamente exteriores a suas atribuições protocolares. A fala do próprio gestor aos funcionários, reproduzida a mim em entrevista de 23/11/2012, está permeada de um sentido de intercâmbio, na medida em que ele costumava lhes dizer que "não é gestor", mas "está gestor". Afirmava, ainda, que estava no "topo da pirâmide", mas que se ela não tivesse uma base sólida, seria ele a cair do lugar mais alto. 
esportivas do centro educacional. ${ }^{125}$ Vemos, assim, que muitos interessados em utilizar o CEU eram levados a interagir em reuniões, de modo a criar uma intensividade de âmbito político. Somada à probabilidade de encontros presenciais nas exíguas ruas internas do CEU, essa intensividade no âmbito político aumentava o teor compulsório das interações, capaz de fazer frente às dificuldades de aceleração da política cotidiana próprias de contextos extensivos. ${ }^{126}$

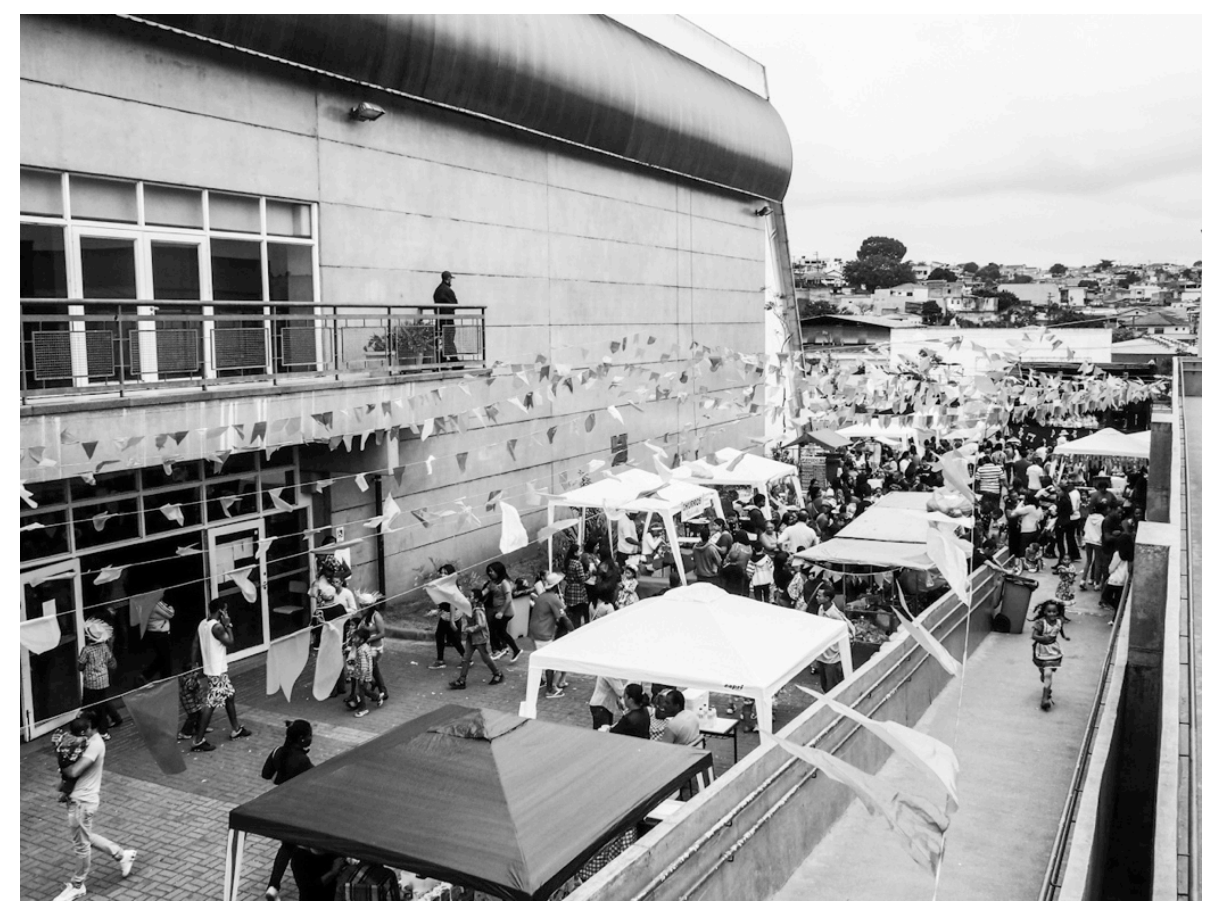

Figura 40 - Festa junina realizada no CEU Vila Rubi em 15/06/2013.

Festas periódicas promovidas pela gestão constituíam um outro conjunto importante de espaços para interações voluntárias: festas de expressões juninas, natalinas e populares, festa de aniversário do CEU etc. Apesar da variação temática, havia parcerias e procedimentos

\footnotetext{
${ }^{125}$ Podemos supor que a falta de destaque nas reuniões dos conselhos educacional e estudantil deva-se à ausência de incentivos semelhantes à participação. $\mathrm{O}$ próprio conselho gestor teria passado por um esvaziamento nos últimos anos da gestão de Cláudio Ferreira, e o gestor colheu indícios de que isso acontecia pela ausência de motivos para reclamação - ao que acrescentamos a ausência de incentivos à participação, da forma como existiam nos supracitados conselhos cultural e esportivo. Outro canal de diálogo a ser mencionado consistia numa caixa para depósito de sugestões, elogios e reclamações que, de acordo com funcionários da gestão, teria recebido uma quantidade gradativamente menor de contribuições, seguindo a explicação do gestor sobre o esvaziamento do conselho. Em contrapartida, participei de reuniões do conselho cultural nos dias 10/04/2013 e 08/05/2013, para as quais fui prontamente convidado. A proeminência deste conselho também é indicada pelo fato de que ele teria sido inspirado numa iniciativa anterior semelhante, desenvolvida com a participação do gestor Cláudio Ferreira no CEU Navegantes - conforme depoimento prestado a mim por Viviane Ramos, em 02/05/2013.

${ }^{126}$ Já observamos que, pelo interesse que despertavam, os cursos promovidos durante a gestão de Anna Cecília Simões no CEU Butantã também atuavam como fatores intensivos complementares à extensividade predominante.
} 
consolidados que facilitavam a organização das festas: prestadores que tinham uma relação já consolidada com o CEU organizavam barracas com diversos tipos de comes e bebes; uma feira de artesanato atraía outras tantas pessoas interessadas em vender e comprar mercadorias; apresentações de alunos das escolas ou dos cursos organizados pela gestão tinham lugar no teatro; a biblioteca administrava uma barraca que oferecia livros para serem trocados ou doados; um palco em estrutura metálica desmontável, construído com recursos angariados em festas precedentes, recebia apresentações culturais e sorteios de rifas; entre outras atrações. ${ }^{127}$ Diversas atrações assim reunidas reforçavam-se mutuamente, trazendo novamente fatores de intensividade importantes para aumentar o público, que em algumas ocasiões chegou a alcançar a marca de 7 mil pessoas. ${ }^{128}$

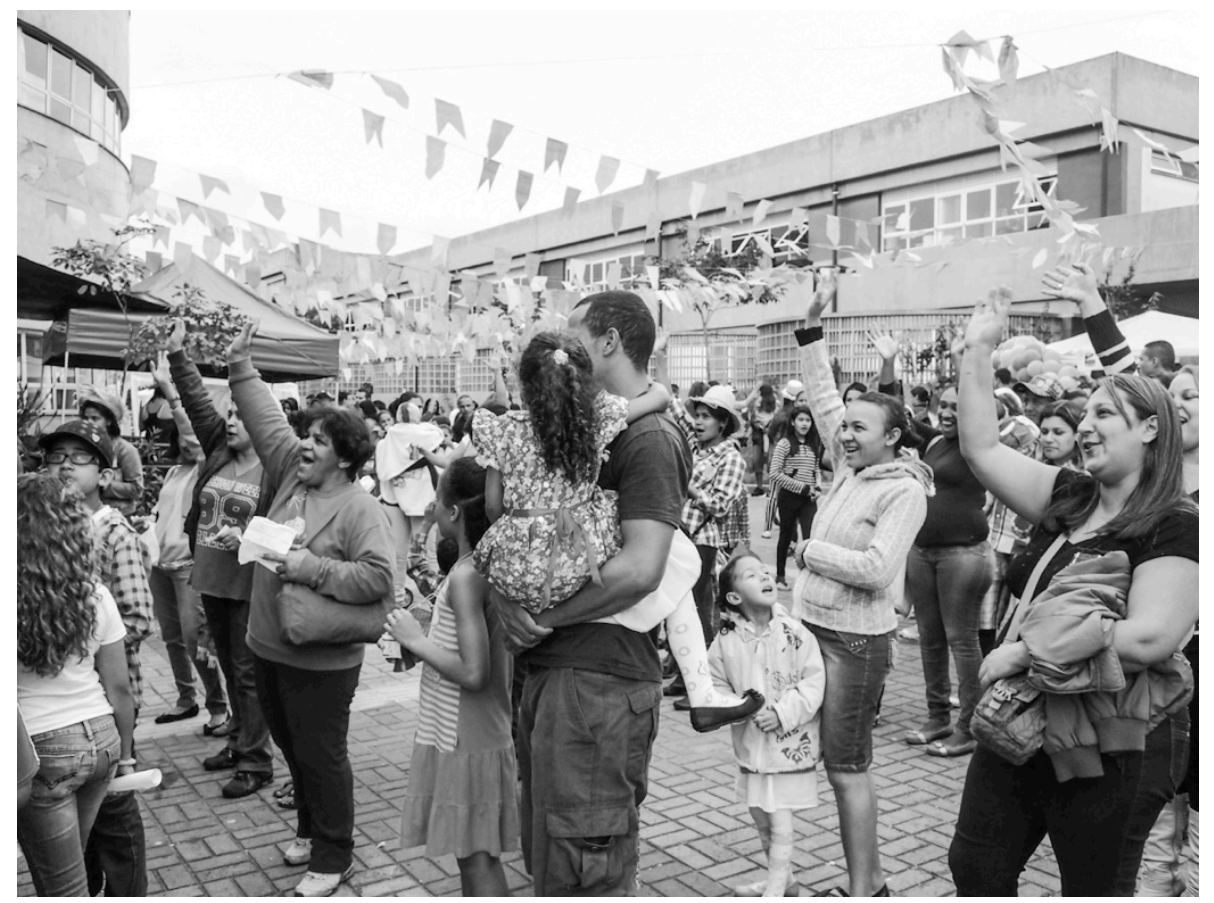

Figura 41 - Sorteio de rifas na festa junina do CEU Vila Rubi, em 15/06/2013.

\footnotetext{
${ }^{127}$ A exemplo do que presenciei em 05/10/2013, os aniversários do CEU contavam com um bolo de vários metros, cortado e distribuído a pessoas de uma extensa fila. Na festa junina de 15/06/2013 havia também um brechó solidário, com itens de vestuário sendo vendidos a um ou dois reais, além de um espaço de distribuição de gêneros alimentícios. As rifas eram sorteadas ao longo de todo o período da festa, e o último sorteio oferecia uma bicicleta. Podemos considerar que todos esses fatores eram maximizadores de intensividades.

${ }^{128}$ Conforme depoimento de Cláudio Ferreira, de 22/03/2012.
} 


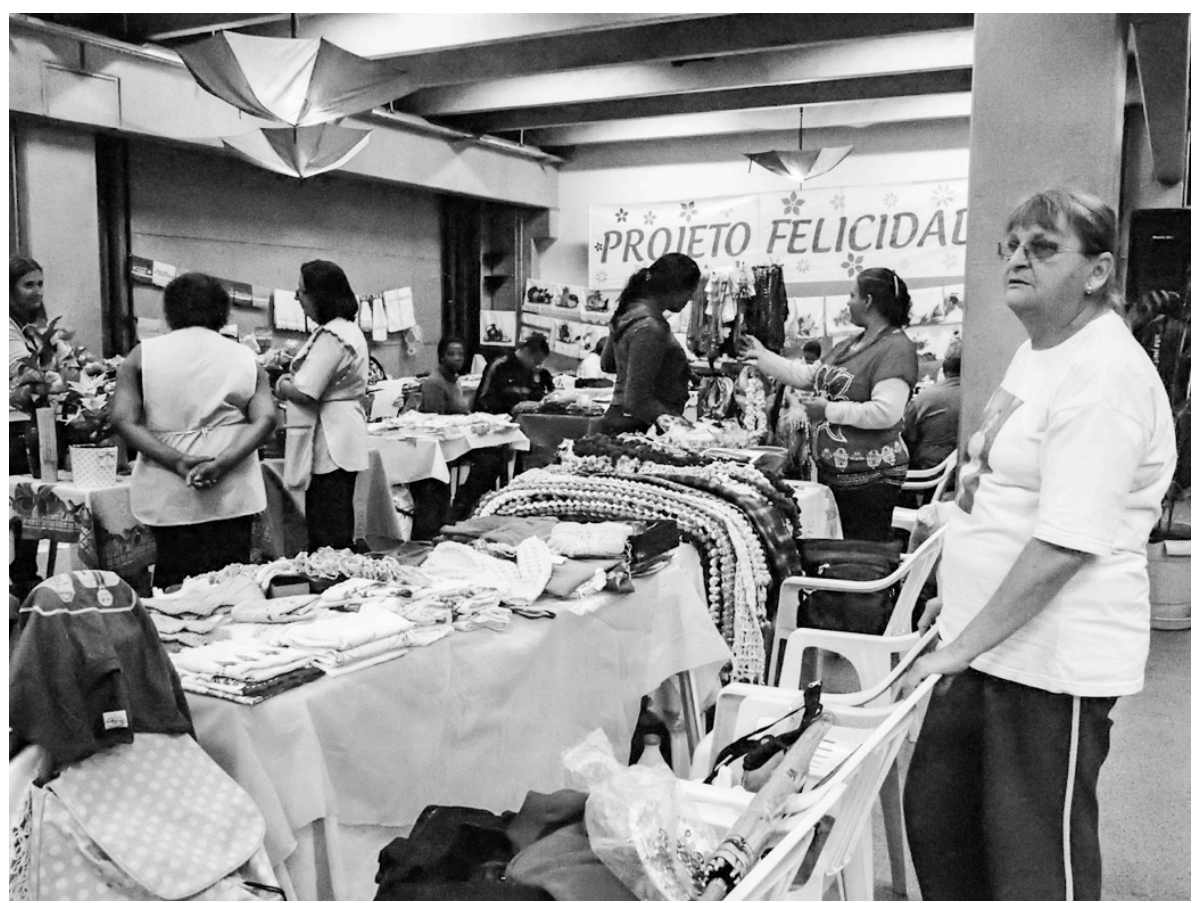

Figura 42 - Barracas de artesanato na festa junina do CEU Vila Rubi, em 15/06/2013.

Um último conjunto importante de atividades de frequência voluntária promovidas pela gestão consistia no oferecimento de atividades culturais e cursos. Alguns deles eram promovidos pelos núcleos esportivo e educacional, ${ }^{129}$ mas o núcleo mais proeminente era o cultural. O Projeto Felicidade oferecia aulas de artesanato, costura e trabalhos manuais para senhoras da terceira idade, e chegou a contar com aulas diárias e uma frequência de 600 alunas. ${ }^{130}$ Além disso, o Projeto Possibilidades costumava encher mensalmente o auditório do centro educacional com um público juvenil envolvido em discussões sobre cultura periférica, entre outros temas relacionados. ${ }^{131}$ Finalmente, merecem destaque os cursos de teatro, música e dança promovidos

\footnotetext{
${ }^{129}$ Cursos de judô, violão, circo e esportes de quadra, entre outros, eram oferecidos a um público infantil e juvenil, em parte composto por alunos das escolas do CEU Vila Rubi. Um fator intensivo indutor da frequência a essas atividades voluntárias consistia no oferecimento de refeições no intervalo dos cursos, e observei que isso era muito valorizado por alguns dos alunos matriculados. Por outro lado, vimos que no CEU Butantã muitos dos frequentadores dos cursos não provinham das comunidades do entorno, mas de regiões mais distantes da cidade. Além disso, não haveria possibilidade de oferecer refeições, já que aquele CEU não contava com um refeitório central - as refeições eram oferecidas somente no interior das escolas.

${ }^{130} \mathrm{O}$ projeto existe desde o início do CEU, e foi organizado quando Richard Rinaldi, membro do Núcleo de Ação Cultural, observou que muitas senhoras ficavam sem atividades enquanto esperavam pelo término das atividades de seus netos. Posteriormente ampliaram-se as interessadas. As professoras do projeto ministram aulas em regime de trabalho voluntário. Relatos apontaram para a superação de quadros de alcoolismo e depressão graças à frequência ao grupo. As feiras de artesanato montadas para as festas do CEU tinham uma parcela significativa de barracas organizadas por professoras e ex-alunas do projeto (conforme observei nas festas de 05/10/2013 e 15/06/2013).

${ }^{131}$ Os eventos começam com uma palestra, seguida de discussão coletiva e de apresentações culturais. O público encheu o teatro do CEU e participou ativamente das discussões nos eventos em que estive presente (em 18/04/2013, para discutir a relação entre rap e funk, e em 13/09/2013, para discutir o tema mulheres e periferia).
} 
pelo Núcleo de Ação Cultural em parceria com artistas e produtores culturais que também se apresentavam regularmente no CEU, durante as festas e em outras ocasiões. Alguns cursos contavam com o patrocínio anual do Programa de Valorização de Iniciativas Culturais da Prefeitura, o VAI. O apoio foi consquistado em parte com a ajuda da própria coordenadora do núcleo cultural, Viviane Ramos, que desde 2010 oferecia palestras no CEU para formação de produtores culturais, assessorando-os na elaboração de projetos para concorrência em programas de incentivo à cultura. ${ }^{132}$ Entre 2012 e 2013, a coordenadora contribuiu para a aprovação de quase uma dezena de projetos no VAI, e o CEU passou a sediar as atividades de alguns deles.

Em vista do relevo adquirido pelo conselho cultural, pelas festas e pelas atividades artísticas e culturais de um modo geral, não é de estranhar que o gestor Cláudio Ferreira, ao relatar sua trajetória profissional, confira destaque à sua experiência como artista e produtor cultural. ${ }^{133}$ Um papel coadjuvante é assumido pela experiência como professor da rede pública, ainda que ela seja pré-requisito para gestores de CEU, e a dificuldade de reunir todos esses atributos num mesmo profissional parece indicar que o estilo de gestão que viemos observando não é nada comum. É preciso acrescentar, ainda, a oportunidade posta ao gestor de "escolher a dedo" sua equipe, minimizando influências de vereadores locais que, em outros centros educacionais, prejudicam a coesão do trabalho da gestão. O gestor pode convocar, assim, parceiros que também tributavam à arte e à produção cultural um papel preponderante em suas trajetórias, como no caso de Viviane Ferreira. ${ }^{134}$

\subsection{CEUs e escolas}

O estilo de gestão encontrado no CEU Vila Rubi parece relacionado aos códigos e comportamentos provenientes do campo da arte e da produção cultural, trazidos pelos gestores em função de suas trajetórias profissionais. Por outro lado, observamos que a história do CEU

\footnotetext{
${ }^{132}$ Conforme relato prestado a mim por Viviane Ferreira em 02/05/2013.

${ }^{133}$ Cláudio Ferreira é graduado em artes plásticas e passou também por formação em artes dramáticas. Antes de tornar-se gestor do CEU Vila Rubi, foi membro da equipe gestora do CEU Navegantes, e está na origem da criação de uma organização não governamental chamada Trivolim, relacionada à promoção de atividades culturais para $o$ público juvenil.

${ }^{134}$ Diga-se de passagem, a possibilidade de escolher parcerias de trabalho guarda nítida afinidade com a constituição de contextos extensivos.
} 
Butantã é marcada por dois estilos de gestão que podem ser diretamente relacionados a debates internos do campo da educação. Assim, o contraste entre os dois CEUs indica um contraste entre modos de atuação diferentes, um associado ao campo da produção artística e cultural e outro ao da educação. Embora não possamos sugerir mais do que um esboço destes nexos, eles merecem ser mencionados, pois ajudam a fechar a discussão deste capítulo.

As relações entre artistas, produtores culturais, seus patrocinadores e públicos-alvo parecem se configurar como altamente dinâmicas e eletivas, derivadas de escolhas voluntárias. Os grupos envolvidos estão continuamente engajados na busca de oportunidades para assistir e apresentar trabalhos, em função de oportunidades e recursos pouco frequentes, intermitentes e dispersos pela cidade. Em meio a esta elevada mobilidade, a construção de vínculos depende predominantemente de afinidades de sentimentos, valores e visões de mundo relacionados ao próprio ato de produção e consumo artístico e cultural. Esse quadro sugere a existência de uma grande mobilidade em meio a contextos extensivos que favorecem o poder de escolha das pessoas em travar interações. ${ }^{135}$

É significativo que, nesta pesquisa, iniciativas de diálogo presididas por extensividades tenham sido tomadas por profissionais oriundos do campo artístico e cultural. Aqui devemos lembrar não apenas do que acabamos de ver com os gestores do CEU Vila Rubi, mas também da aproximação em relação aos frequentadores da pista de skate do CEU Butantã, realizada pelo músico e produtor cultural - além de professor da rede pública - Caio Uehbe. Com isso queremos sugerir que profissionais do mencionado campo estão habituados a atuar em contextos extensivos, como os que constituem uma gestão de CEU. Eles parecem mais familiarizados com a construção de laços pautados pela simetria e reciprocidade, quando isto acontece numa dinâmica de interações voluntárias. ${ }^{136}$

\footnotetext{
${ }^{135}$ Como aspecto secundário, podemos apontar ainda para uma disposição em celebrar entendimentos coletivos que têm uma certa afinidade com o acolhimento, na medida em que este também envolve fomentos ao diálogo e à reciprocidade.

${ }^{136}$ No capítulo anterior já apontamos indícios de estilos de atuação diferentes entre educadores e profissionais ligados à Secretaria Municipal de Cultura e Esportes. No governo de Marta Suplicy a gestão dos CEUs era compartilhada entre esses vários profissionais, mas com a chegada de José Serra os educadores ganharam primazia em todos os cargos, inclusive no Núcleo de Ação Cultural. Isso serve como retrato da distribuição de cargos do CEU Butantã até recentemente. Em minhas visitas de campo ao CEU Vila Rubi e outros lugares encontrei artistas bastante contrariados com a presença de educadores como gestores culturais. Vale resgatar aqui o depoimento já citado, colhido em um dos centros educacionais de São Miguel em 2008: "quando eram três secretarias, o CEU era mais voltado para fora, mas agora é mais voltado para dentro.[...] O pessoal da educação não tem a cultura de se abrir para outras propostas" (GROSBAUM; CARVALHO, 2008, p. 14). Uma recente iniciativa do governo de
} 
Por outro lado, ao criticar alguns dos últimos gestores do CEU Butantã, certos funcionários e usuários atribuíram-lhes modos de agir e proceder comuns entre professores e diretores de escolas públicas que, no entanto, não seriam apropriados para a realidade cotidiana de centros educacionais. Vale citar a análise da liderança comunitária Fernanda Alvez:

eles [gestores] ainda não se acostumaram que o CEU é um centro, uma escola diferente. Porque essas pessoas que agem assim, elas estão acostumadas a ter uma escola, cercada, com as suas salas de aula, com a diretoria e com a quadra e acabou. Aqui não é assim, aqui tem uma área escolar e tem uma área de lazer, transita pessoas porque vai trabalhar, porque volta do trabalho, quer dizer, é um espaço mais amplo. Existem duas coisas aqui dentro: existe a área de lazer e existe a área da escola. Então você tem que perceber que essas pessoas não têm essa preparação ainda, então para elas isso é novo e o novo é difícil de administrar, entendeu? Por exemplo, ela chega, tromba alguém que está passando para ir para a escola, para o trabalho, alguém que está voltando, e aí ela não sabe quem são aquelas pessoas, se está entrando e o porquê ela está entrando. Se é numa escola convencional ela sabe que ou é aluno, ou é mãe ou pai, ou é professor. Acabou. Então está taxativo, entendeu? Aqui não. ${ }^{137}$

Este raciocínio sugere que a busca da segurança mediante a implementação de separações, que observamos no CEU Butantã, é um fenômeno recorrente em escolas públicas. De fato, ele vai ao encontro de diversas críticas a essas escolas, concernentes à proliferação de muros, grades, portões, trancas e mesmo câmeras de vigilância (não por acaso elas chegam a ser aproximadas da imagem de um presídio). ${ }^{138} \mathrm{~A}$ isto podemos acrescentar a presença expressiva de intensividades, e para tanto basta nos lembrarmos da obrigatoriedade de frequência à escola e das dificuldades de transferência de alunos entre unidades educacionais da rede pública. A situação é semelhante para educadores e funcionários das escolas: como sua progressão de carreira é de longo prazo,

Fernando Haddad mostra-se sensível a este problema e restitui a composição híbrida de profissionais na gestão dos CEUs (SÃO PAULO, 2014; SECRETARIA EXECUTIVA DE COMUNICAÇÃO, 2014).

${ }^{137}$ Conforme entrevista concedida a mim em 17/07/2012.

${ }^{138}$ A associação entre a EMEF do CEU Butantã e um presídio foi feita a mim por um dos alunos do curso de vídeo que ofereci naquela escola, em 2011. O aluno fazia referência ao aumento de grades e à então recente implantação de câmeras de vigilância. Em sua etnografia sobre escolas de ensino médio, Pereira (2010, p. 84) também encontrou esta associação entre escola e presídio: "Não raro tem-se a comparação, principalmente entre os alunos, das escolas com os presídios". Alexandre Pereira aponta para um recrudescimento da "busca pelo controle rígido dos comportamentos" por parte da instituição escolar, e um correspondente "aumento das ações estudantis que colocam em xeque a função disciplinadora e de controle da escola". Mais do que isso, "a dimensão das práticas de lazer e de gozação [dos alunos] tem se sobreposto às dinâmicas de formação e conformação dos indivíduos [pela escola]"(op. cit., p. 111). O fenômeno parece não se restringir ao Brasil. É de se supor que a proliferação de separações de espaço venha como resposta, ainda, à diminuição do poder de coerção que a escola possuía, décadas atrás, sobre os alunos, por meio da possibilidade de reprovações e mesmo da agressão física. 
com benefícios progressivos que desincentivam à saída, a grande parcela de profissionais que está insatisfeita com condições de trabalho e remuneração vê-se coagida a permanecer na carreira. ${ }^{139}$

Esta associação de separações e intensividades presente no campo da educação parece constituir uma dinâmica semelhante à que vimos para o CEU Vila Rubi: a aceleração produzida por interações de tipo compulsório seria compensada com a multiplicação de dispositivos articuladores e reguladores. No entanto, a inexistência de extensividades predominantes torna improvável quaisquer outras aproximações entre o CEU Vila Rubi e escolas em geral: nestas, os dois contextos produtores de interações não voluntárias saltam para o primeiro plano, frequentemente presidindo animosidades e conflitos entre educadores, pais e alunos.

Se as escolas parecem exibir grandes desproporções nos papéis exercidos por cada tipo de contexto, isso não quer dizer que as extensividades sejam inexistentes. As raras oportunidades de escolher encontros podem motivar afastamentos interpessoais, numa dinâmica semelhante à que vimos para o CEU Butantã. Mas se naquele centro educacional havia espaços amplos e abertos que davam margem a acomodações e estabilizações, nas escolas convencionais a recorrência de interações indesejáveis e inevitáveis faz com que as possibilidades de evitação de encontros atuem como válvulas de escape da pressão resultante. Assim, poderíamos compreender em parte o desinteresse dos alunos por conteúdos que dependem de sua disposição para serem absorvidos, ${ }^{140} \mathrm{e}$ a frequente recorrência, por parte dos professores, aos pedidos de transferência de unidade educacional. ${ }^{141}$

\footnotetext{
${ }^{139}$ Haveria também separações entre professores, na medida em que critérios de premiação e avaliação de desempenho discriminam individualmente os profissionais, fragmentando seu poder de ação e desincentivando composições de conjunto.

${ }^{140}$ Desde a instauração da "progressão continuada" pela gestão Luiza Erundina (1989-1992) e pelo então secretário de Educação Paulo Freire, a reprovação de alunos passou a ocorrer apenas ao final de cada ciclo, a cada quatro anos letivos. Podemos dizer que isso criou um contexto extensivo no âmbito pedagógico do ensino público paulistano, que fez com que a efetivação do aprendizado dependesse predominantemente do interesse do aluno. $\mathrm{O}$ atual secretário de Educação Cesar Callegari associou a progressão continuada à má qualidade do ensino em São Paulo e ao índice de 38\% de analfabetismo entre alunos de 9 e 10 anos que terminam o primeiro ciclo (CALLEGARI, 2013 - artigo publicado no jornal Folha de S.Paulo em 17/08/2013). A partir de 2014, as escolas municipais passaram a contar com reprovações anuais e avaliações bimestrais dos alunos. A possibilidade de medir, acompanhar e cobrar melhoras de desempenho representa um contexto intensivo que põe em contato professores, alunos, familiares, diretores e instâncias superiores de governo. A mudança traz um incremento de interações não voluntárias entre professores e alunos. Seguindo os conceitos aqui propostos, a melhora no desempenho escolar dos alunos não seria determinada simplesmente por esta mudança, mas pelo modo como cada unidade escolar fará uso da intensividade.

${ }^{141}$ A impermanência de professores e educadores é muitas vezes citada como um dos fatores mais desestruturadores da rotina de uma escola (OLIVA, 2010). No CEU Butantã, o problema preocupava a diretora da EMEF (conforme relato prestado a mim em dezembro de 2011) e a coordenadora pedagógica da EMEI (de acordo com conversa que travei em 23/04/2013).
} 
Os fatos empregados neste esboço de análise das escolas costumam ser mobilizados, também, por uma parcela minoritária e crítica de profissionais e pesquisadores. Dentro do campo da educação, essas pessoas filiam-se à esquerda política e à pedagogia da libertação freiriana, como no caso já observado da educadora Anna Cecília Simões, gestora do CEU Butantã durante a gestão Marta Suplicy. A promoção de "acesso sem nenhum impedimento" ${ }^{142}$ constrói uma oposição em relação ao que vimos. Para esta parcela de educadores, a maximização de extensividades é incompatível com a presença de intensividades e separações. Uma polarização análoga estrutura o plano de valores e práticas, de modo que a promoção do acolhimento associando-se exclusivamente às extensividades - é vista como incompatível com a preocupação com a segurança - relacionada às separações. Observamos que esta radicalização de posicionamentos está presente na história do CEU Butantã, mas agora ela também parece útil para indicar uma tensão entre duas formas opostas de atuação que organizam o campo da educação de um modo geral.

Os gestores do CEU Vila Rubi valeram-se de um terceiro estilo de gestão, em parte atribuível a trajetórias profissionais híbridas, que associaram à experiência de educadores aquela proveniente de práticas artísticas e culturais. Isso trouxe uma certa facilidade de movimentação em contextos permeados por extensividades e interações de livre escolha. Além disso, a atuação dos gestores não se pautou por escolhas dicotômicas de contextos e valores, sem que isso trouxesse prejuízos ao acolhimento. Recursos e canais de diálogo foram entregues aos usuários do centro educacional, em meio a mobilizações menores mas não desprezíveis de intensividades, separações e preocupações com a segurança. Esses fatores foram vistos como integrantes de uma mesma equação, na qual não se deixou de almejar, como resultado, o favorecimento dos frequentadores. Nos dois centros educacionais encontramos partidários do acolhimento expressamente favoráveis à expansão de extensividades, mas no CEU Vila Rubi ela foi vista como parte de uma calibragem que também contava com um uso modulado de intensividades e separações. Isso determinou mudanças gradativas em suas proporções, capazes de se adequar às exigências e possibilidades manifestadas pelas dinâmicas interacionais a cada momento do tempo.

Enfim, podemos ver que os educadores que se sucederam na administração do CEU

\footnotetext{
${ }^{142}$ Novamente empregamos aqui esta ilustrativa expressão, atribuída à ex-gestora Anna Cecília Simões pela bibliotecária Regina Ferreira em conversa de 05/04/2013.
} 
Butantã produziram, num primeiro momento, uma maximização da livre escolha de ação e interação que trouxe grandes parcelas de incerteza no cotidiano; isso em parte motivou uma reação veemente a favor da organização e da segurança, trazida por um outro tipo de educadores, mais inclinados a trabalhar com contextos separadores. Por sua vez, o CEU Vila Rubi foi mais bem-sucedido na promoção do acolhimento por contar com gestores filiados ao universo da arte e da produção cultural. Ao produzir uma expansão gradativa das extensividades, eles contaram com incrementos de incerteza mais fáceis de serem administrados e incorporados nas dinâmicas interacionais. Desta forma, as separações passaram a ser cada vez menos necessárias para garantir a segurança.

Não devemos usar as diferenças observadas entre campos profissionais para construir um quadro homogêneo e inflexível deles, mas para identificar contrastes e tendências gerais. Obviamente há variações e mudanças no interior desses campos, e isso ficará claro quando observarmos mais de perto o campo da biblioteconomia, no próximo capítulo. Veremos que bibliotecários podem ou favorecer o acolhimento e aproximar-se do estilo de gestão que associamos aos produtores culturais, ou dificultar a sua promoção - caso em que podem ser aproximados ao campo da educação. 


\section{CAPÍTULO 3 - ENTRE "USUÁRIOS" E "LIVROS": INVESTIGAÇÃO E INTERVENÇÃO NAS BIBLIOTECAS}

No capítulo anterior observamos como os projetos que orientaram a implementação dos CEUs em São Paulo foram concretizados nos CEUs Butantã e Vila Rubi, e como passaram por modificações posteriores para produzir resultados muito diferentes na promoção do acolhimento. A maximização da liberdade de agir e interagir, no CEU Butantã, foi seguida de uma implantação de controles e normas que terminaram por afastar os usuários do centro educacional, relacionando-se ainda com o predomínio de relações conflitivas entre funcionários. Esse cenário parece ser comum em muitos outros CEUs da cidade, e pode ser contrastado com o do CEU Vila Rubi, na medida em que este se constitui como um caso mais raro e bem-sucedido de promoção do acolhimento. Neste segundo caso, observamos uma construção gradativa de liberdades, associada a parcelas menores de controles e induções de interação.

Para as análises precedentes, levamos em conta a grande diversidade de aspectos presentes no cotidiano da gestão de um centro educacional. A análise das bibliotecas dos CEUs Butantã e Vila Rubi, a ser realizada neste capítulo, permite que nos aprofundemos em um conjunto menor e mais manejável de questões, capazes de serem colocadas num quadro de conjunto mais claro e articulado. Além disso, parte dos problemas aqui presentes se repetem com mais evidência em ambas as bibliotecas, e isso potencializa o procedimento comparativo empregado na pesquisa. Um ponto importante para compreender as relações entre este capítulo e o anterior está na semelhança entre bibliotecas e gestões de CEU, no sentido de que ambas oferecem atividades abertas ao público que, para serem bem-sucedidas, dependem da capacidade de despertar o seu interesse. Esta condição é muito diferente daquela existente nas escolas do CEU, porque neste caso a frequência é em grande medida compulsória.

Para as análises que seguem, continuaremos utilizando a discussão conceitual realizada no primeiro capítulo da pesquisa. Em suma, vamos tratar separadamente as interações interpessoais, de um lado, e os contextos que lhes servem de palco e as influenciam, de outro. Diversos aspectos da realidade podem ser vistos como contextos: espaços, normas de funcionamento das bibliotecas, vínculos empregatícios, distribuições de turnos de trabalho, entre outros. Para se relacionar, as pessoas precisam levar em conta o conjunto dessas influências diversas. 
Os contextos podem ser classificados em três tipos básicos. Enquanto contextos extensivos asseguram a liberdade de escolha em interagir, os outros dois tipos atuam de modo mais contundente sobre as interações, e podem ser considerados como produtores de dois tipos de dinâmicas não voluntárias: contextos intensivos obrigam as pessoas a se relacionarem, e contextos separadores representam interrupções ou intermitências das interações. Cada um dos três tipos de contexto oferece vantagens e desvantagens, de modo que nenhum deles pode ser visto como exclusivamente desejável ou indesejável. ${ }^{143}$

Não pretendemos empregar esta tipologia como uma camisa de força, mas como um conjunto inicial de ferramentas que devem servir às situações específicas encontradas, combinando-se entre si e com outros problemas na medida do necessário. De saída, fica claro que as bibliotecas - e gestões - constituem-se fundamentalmente como contextos extensivos, já que, como observamos acima, a frequência a esses equipamentos é voluntária.

\subsection{Bibliotecas de $\mathrm{CEU}^{144}$}

Nas bibliotecas, as interações envolvem públicos de idades diversas, assistentes de ensino, profissionais de limpeza, além dos próprios bibliotecários. Muitas das particularidades que diferenciam a biblioteca dos outros equipamentos de CEU devem-se à presença destes últimos profissionais, dotados de formação específica e dilemas próprios. São eles os principais responsáveis pelo planejamento das atividades da biblioteca, pelo atendimento qualificado ao público e pela execução de processos técnicos voltados à aquisição e à manutenção de acervos.

A construção dos 45 CEUs, a partir de 2003, praticamente duplicou o número de bibliotecas públicas existentes na cidade de São Paulo. Mas, como as bibliotecas de CEU se vinculam, em termos administrativos e financeiros, à Secretaria de Educação, apresentam diferenças importantes em relação às demais, administradas pela Secretaria de Cultura.

Em minhas visitas de campo, essas diferenças foram comumente referidas pelos

\footnotetext{
${ }^{143}$ Lembramos que estamos empregando os termos contexto e âmbito em sentidos diferentes: o primeiro refere-se às condicionantes das interações - que podem ser classificadas nos três tipos supracitados -, e o segundo refere-se à natureza destas condicionantes - espacial, legal, temporal etc. Desta forma podemos falar em contextos intensivos de âmbito legal, contextos separadores de âmbito espacial e assim por diante.

${ }^{144}$ Grande parte dos dados subsequentes pode ser confirmada na pesquisa mais pormenorizada de Lemos (2012).
} 
bibliotecários de CEU para justificar uma grande insatisfação com suas condições de trabalho. Segundo alguns deles, não há uma coordenação regional que articule a atuação das várias bibliotecas de CEU, nem uma política de atualização das coleções; apesar da existência de certas normas de atendimento comuns a todas as bibliotecas, faltam diretrizes específicas de trabalho para as bibliotecas dos CEUs, desde as que definem horários de funcionamento até as que orientem o atendimento ao público de um modo geral. ${ }^{145}$ Faltam também regulamentações definidoras de padrões salariais, progressões de carreira, qualificações e quantidades de profissionais a serem contratados em cada biblioteca. Fala-se ainda de um desinteresse e de uma incapacidade de entendimento, por parte da Secretaria de Educação, para com as demandas dos bibliotecários de CEU.

Uma associação chamada ABICEU foi criada por uma parcela dos bibliotecários de CEU ${ }^{146}$ para cuidar das reivindicações específicas da categoria. Nesse sentido, poderíamos dizer que as diferenças de regulamentações de trabalho dos profissionais lotados em secretarias diferentes acabam produzindo um contexto separador que dificulta ações conjuntas. Também é possível dizer que a regulamentação precária do conjunto das bibliotecas de CEU produz contextos extensivos, que deixam nas mãos dos gestores locais uma grande quantidade de decisões, produzindo uma variação considerável nas práticas de uma biblioteca para outra. Assim, justificam-se as discrepâncias significativas que encontrei entre as bibliotecas dos CEUs Butantã e Vila Rubi. ${ }^{147}$

O regimento interno dos CEUs regulamenta minimamente as atividades dos bibliotecários. O principal ponto estabelecido é a diferença entre o bibliotecário coordenador do equipamento, contratado por nomeação política, e os bibliotecários subordinados, contratados como efetivos e

\footnotetext{
${ }^{145}$ Atualmente, está em desenvolvimento o programa "Quem lê sabe por quê", iniciativa da Secretaria Municipal de Educação para orientar os trabalhos das bibliotecas de CEU no sentido de incentivar o hábito da leitura e formar mediadores de leitura. Mais informações em:

<http://portalsme.prefeitura.sp.gov.br/anonimosistema/detalhe.aspx?List=Lists/Home\&IDMateria=1497>. Acesso em: 08/08/2014.

${ }_{146}$ Trata-se da Associação dos Bibliotecários de CEU - ABICEU, que conta com um blog no endereço: <http://abiceudivulgacao.blogspot.com.br> (acesso em: 08/08/2014). As bibliotecárias do CEU Vila Rubi estão diretamente envolvidas nesta associação.

${ }^{147}$ Além disso, a dificuldade que os membros ativos da ABICEU - como os bibliotecários do CEU Vila Rubi - têm encontrado para conseguir mais adeptos parece indicar o efeito conjunto desses contextos separadores e extensivos, como vimos acontecer na análise do CEU Butantã: os primeiros criam dificuldades para unir forças em prol de reivindicações da categoria, e os segundos permitem aos profissionais menos propensos a acreditar em melhorias que abdiquem da participação. O diagnóstico desta "desmotivação" foi realizado a mim por uma das bibliotecárias do CEU Vila Rubi em 08/10/2013. Segundo ela, apenas cerca de metade dos bibliotecários de CEU encontra-se filiado à ABICEU.
} 
inseridos na carreira de servidor público municipal. O primeiro está diretamente subordinado à gestão do CEU, tendo como uma de suas funções principais a elaboração e coordenação da execução de projetos de formação educacional e cultural da biblioteca, como exposições, oficinas e saraus. Os segundos têm funções relacionadas à assessoria do coordenador, ao atendimento ao público e à execução de processos técnicos em geral (catalogação de itens de acervo, sinalização de estantes, entre outras atividades).

Quanto à frequência do público, as bibliotecas tendem a enfrentar grandes dificuldades. ${ }^{148}$ Certamente as baixas taxas de visitação devem-se, em parte, à diminuição de recursos destinados aos CEUs nos últimos anos. A biblioteca do CEU Butantã, conforme relato de sua coodenadora, possuía ao menos o dobro de funcionários durante o mandato de Marta Suplicy (2001-2004), e a aquisição de acervos era muito mais expressiva. Esses números caíram ao longo dos dez anos de vida da instituição, com a redução crescente de verbas e recursos, agora em reavaliação pela gestão de Fernando Haddad, iniciada em 2013.

Independentemente da quantidade de recursos alocados, certos bibliotecários e gestores de CEU consideraram a biblioteca como o último equipamento que interessa ao usuário, contrapondo-a, neste sentido, à atração suscitada pelas piscinas e telecentros. Mesmo os alunos das escolas dos CEUs não se sentem facilmente estimulados a frequentar as bibliotecas, ainda que constituam boa parcela de seu público. As atividades procuradas dependem muito do público, mas se inclinam sobretudo à leitura recreativa, a trabalhos de escolas ou cursos profissionalizantes, além do uso da Internet, mas não a pesquisas ou à leitura de conteúdos menos relacionados ao cotidiano dos usuários.

A ausência de parâmetros para gestão das bibliotecas de CEU produz também questionamentos acerca de sua identidade institucional. Em relação às bibliotecas convencionais, as bibliotecas de CEU possuem um caráter misto e inédito, destinando-se ao atendimento tanto de escolas quanto de comunidades do entorno e cidadãos em geral, tanto de públicos infantis quanto de adultos. A diversidade de públicos suscita questões a respeito de como articulá-los, com destaque para uma tendência em associar as práticas das bibliotecas aos códigos de comportamento provenientes do ambiente escolar. Desta forma, funcionários de outros

\footnotetext{
${ }^{148}$ Uma pergunta de questionário aplicado entre 10/12/2010 e 15/02/2011 a 36 bibliotecários de CEU por Barlem (2012) reforça a impressão geral das dificuldades de trazer público para as bibliotecas. A pesquisadora fez a pergunta: "O índice de frequência na biblioteca por parte da comunidade é satisfatório?" e recebeu respostas distribuídas da seguintes forma: 3 ótimo; 8 bom; 8 regular; 17 ruim.
} 
equipamentos dos CEUs podem observar as bibliotecas como se fossem salas de leitura convencionais presentes no interior das escolas, e os próprios alunos podem trazer expectativas de relacionamento com as bibliotecárias semelhantes àquelas mantidas com educadores e inspetores de ensino. Existe ainda uma dificuldade do público em geral em perceber que a biblioteca não se destina apenas às escolas. Estes problemas serão abordados oportunamente, mas por ora é importante observar que o transbordamento das práticas do universo escolar, que vimos ocorrer na gestão dos CEUs, também pode ser observado em suas bibliotecas. ${ }^{149}$

A mescla dos públicos infantil e adulto parece demandar uma articulação entre bibliotecários habituados ao trato com um e com outro, os quais, sob a Secretaria da Cultura, trabalhavam em bibliotecas diferentes. Conforme o depoimento da coordenadora da biblioteca do CEU Butantã, as bibliotecárias acostumadas ao trato com o público infantil tendem a desenvolver um modo de expressão mais espontâneo e alegre, que eventualmente as colocava em desvantagem em reuniões da Secretaria da Cultura quando encontravam colegas voltadas ao público adulto, habituadas a uma postura mais séria e compenetrada. Nas rotinas de trabalho, estas últimas seriam mais rígidas e inflexíveis, enquanto as primeiras estariam muito mais predispostas a práticas relativas à improvisação e flexibilização de procedimentos. ${ }^{150}$ Essas diferenças tendem a ser menos importantes entre os bibliotecários mais jovens, com grande parte da carreira profissional transcorrida dentro dos CEUs, como no caso dos bibliotecários do CEU Vila Rubi. No CEU Butantã, a trajetória das bibliotecárias parecia mais marcada por esses pertencimentos, mas independentemente dos percursos de carreira, havia diferenças na disposição de flexibilização ou rigor na observação de procedimentos, como veremos mais adiante.

Outra clivagem importante é a que coloca a preocupação com procedimentos técnicos em oposição ao trabalho de atendimento ao público morador de áreas desfavorecidas da cidade. Bibliotecários com perfil mais técnico têm dificuldade em lidar com um público não habituado à pesquisa e à leitura, como se depreende deste depoimento de bibliotecário, colhido por Lemos (2012, p. 117): "Ninguém faz biblioteconomia para trabalhar com quem não sabe ler e escrever.

\footnotetext{
${ }^{149}$ Esta é uma dificuldade importante que observei no cotidiano das bibliotecas dos CEUs Butantã e Vila Rubi, mas Lemos (2012) colheu relatos entre bibliotecários de CEU que apontam para os mesmos problemas. Por exemplo: "O pessoal das unidades [escolares] acha que a biblioteca é deles, porque eles estão no CEU eles acham que todos os equipamentos estão à disposição deles." (LEMOS, 2012, p. 90). Outro bibliotecário afirma: "Ao menos uma vez por semana eu tenho que responder à pergunta: 'Eu posso usar a biblioteca do CEU, mesmo não estudando aqui nas escolas?"' (LEMOS, 2012, p. 94).

${ }^{150}$ Seria plausível supor aqui uma analogia com a estigmatização de educadores que trabalham com alunos mais novos, por parte daqueles dedicados a alunos mais velhos. Encontrei menções gerais a essas estigmatizações em conversas com educadores dos Centros de Educação Infantil (CEIs) nos dois CEUs estudados.
} 
Não é colocado na nossa cabeça que a gente vai estudar para trabalhar com gente excluída". ${ }^{151}$ Desta forma, os desafios do acolhimento aqui examinados passam principalmente pela interação entre esses usuários e os bibliotecários, além das interações entre estes últimos.

\subsection{Biblioteca do CEU Butantã: "usuários" ou "livros"}

A biblioteca do CEU Butantã localiza-se no nível térreo do bloco pedagógico, em uma posição de grande proximidade em relação a outros equipamentos. No limite mais próximo à praça principal do CEU, a biblioteca faz divisa com o telecentro e a padaria-escola, compondo um conjunto que promoveria, para os defensores do projeto original dos CEUs, uma "política do pão e livro", oferecendo "alimento para o corpo e para a alma" dos visitantes. ${ }^{152}$ Do outro lado da biblioteca, e nos pavimentos superiores, encontram-se os espaços vizinhos da EMEF (Escola Municipal de Ensino Fundamental) - que também são usados para as aulas da ETEC (Escola Técnica Estadual) e da EJA (Educação de Jovens de Adultos), no período noturno - e, mais adiante, a EMEI (Escola Municipal de Educação Infantil) e o CEI (Centro de Educação Infantil). ${ }^{153}$ Com exceção do CEI, que tem seu acesso principal pela outra extremidade do bloco educacional, os alunos de todas essas escolas passam diariamente pelo corredor de acesso que tem em um de seus lados a parede amplamente envidraçada da biblioteca, permitindo a entrada de luz e dos olhares das imediações. Em frente à biblioteca, do outro lado desse corredor, encontram-se as piscinas, que há até pouco tempo permaneciam quase sempre fechadas ao público. O lado oposto da biblioteca, também dotado de amplas vidraças, faz divisa com uma grande área nos fundos do CEU. Originalmente aberta à visitação pública, essa área foi cercada em meados da década passada, quando passou a funcionar como espaço destinado ao recreio das escolas.

\footnotetext{
${ }^{151}$ Vale citar ainda outro depoimento colhido por Lemos (ibid.): "Infelizmente eu acho que $70 \%$ ou $80 \%$ dos bibliotecários ainda não estão preparados para essa realidade de periferia. Porque eles se apegam muito ao tecnicismo da profissão e esquecem o lado humano".

${ }^{152}$ De acordo com entrevistas com Anna Cecília Simões, realizadas nos dias 23/05/2013, 06/06/2013 e 19/07/2013.

${ }^{153}$ A articulação destes equipamentos e espaços pode ser melhor compreendida com a consulta às figuras 9 e 25 , nos capítulos precedentes.
} 


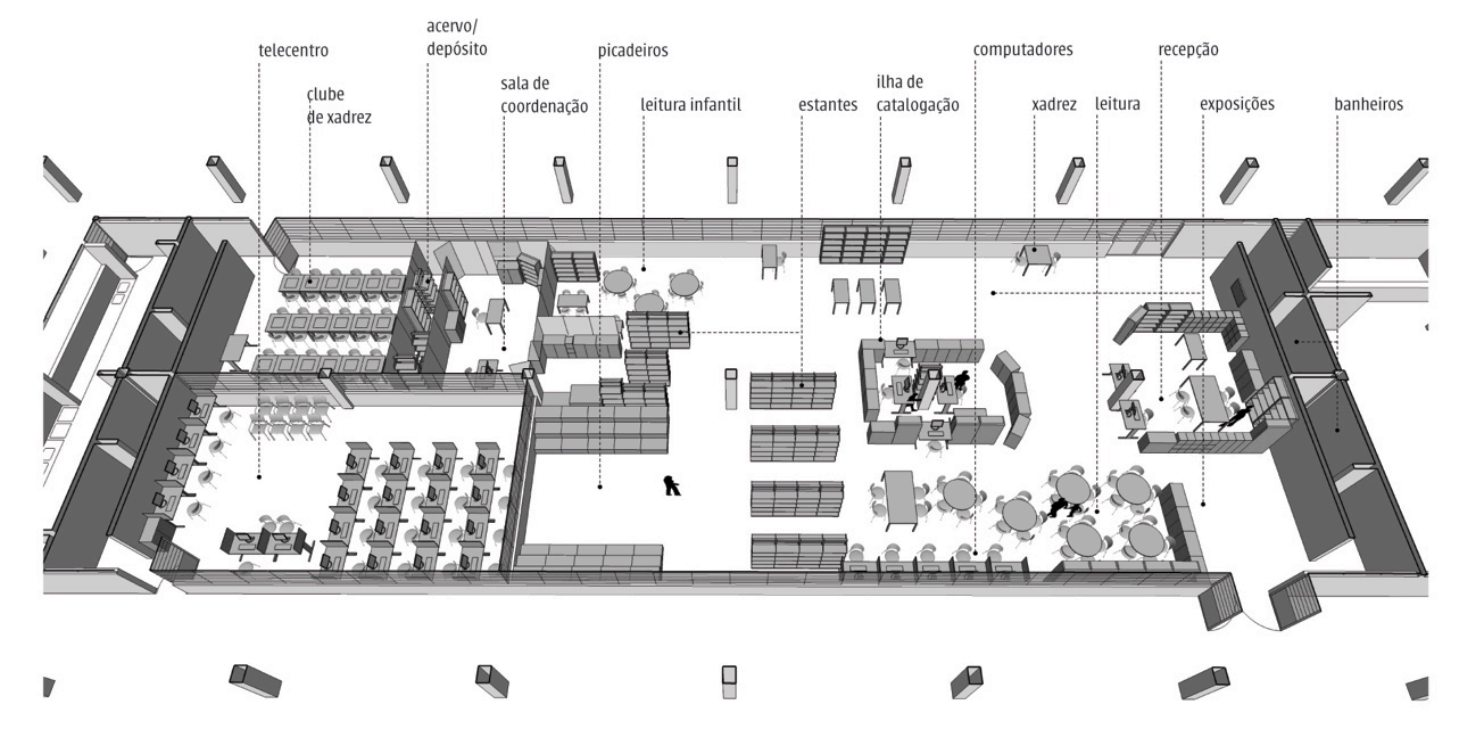

Figura 43 - Perspectiva ilustrativa da biblioteca do CEU Butantã (2013).

A imagem acima apresenta os espaços internos da biblioteca do CEU Butantã, tal como estavam configurados até o fim do ano de 2013. Vamos nos reportar a ela no decorrer deste capítulo, mas por ora gostaríamos de chamar atenção para algumas de suas características gerais. Apesar de os ambientes terem sido bastante modificados em relação ao projeto original (ver figura 44 adiante), as premissas que orientaram o partido arquitetônico do CEU continuam fazendo-se presentes aí, com maior ou menor intensidade. A biblioteca é composta por um espaço interno amplo e praticamente único, dotado de boa permeabilidade visual e espacial, apesar das demarcações de ambientes internos com armários e estantes, e apesar de boa parte de suas janelas receberem cortinas retráteis e outras obstruções menores. O ambiente interno original conta com cerca de 550 metros quadrados, tendo sofrido uma redução por conta da instalação do clube de xadrez, de acordo com um processo que será analisado em detalhes mais adiante. 


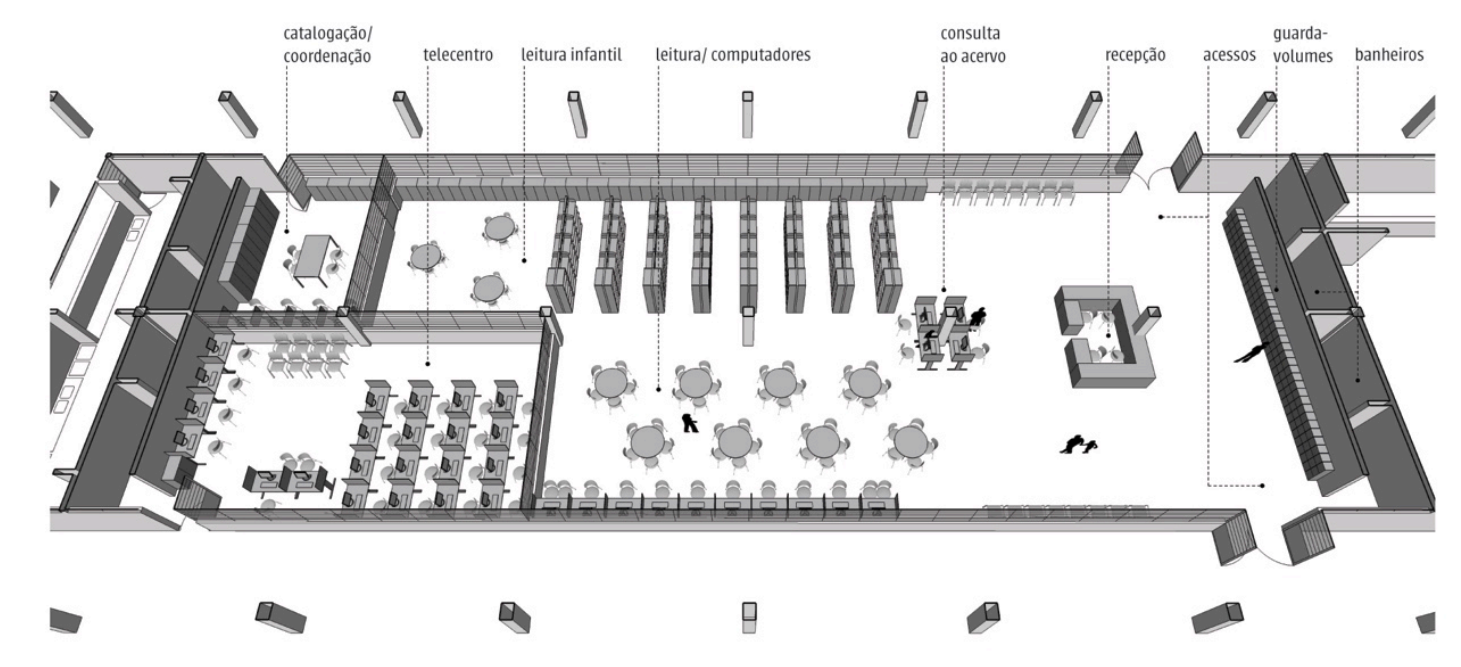

Figura 44 - Perspectiva ilustrativa do projeto original da biblioteca do CEU Butantã.

Talvez o aspecto do projeto original que mais sofreu alterações foi a permeabilidade espacial, já que, das duas entradas localizadas em lados opostos da biblioteca, apenas uma estava funcionando. O segundo acesso, oposto ao primeiro, ficou permanentemente fechado desde que o espaço dos fundos do CEU passou a ser de uso exclusivo das escolas. Apesar do tamanho de seu interior, os espaços de permanência do público concentravam-se ao redor das mesas para adultos - ao lado da porta de entrada - e para crianças, aos fundos da biblioteca. Os funcionários revezam-se na mesa de recepção, nunca desatendida, e ocupam de modo mais intermitente os outros espaços administrativos.

Apesar dos ilustres vizinhos e das convidativas características espaciais, encontrei a biblioteca deste CEU vazia na maior parte das minhas visitas de campo. Algumas turmas de alunos da EMEI e do CEI, trazidas ao espaço infantil da biblioteca por suas professoras, representavam os visitantes mais assíduos, além de eventuais grupos de alunos da ETEC, que se reuniam nas mesas de leitura, antes do início de suas aulas noturnas, para desenvolver trabalhos letivos. Certos visitantes frequentavam mais assiduamente a biblioteca por um período curto de tempo, muitos deles interessados em acessar o site Youtube, que até 2013 era indisponível no telecentro dos CEUs. Esporadicamente, duplas de jovens ocupavam a única mesa destinada ao jogo de xadrez, localizada no espaço interno da biblioteca. O único frequentador assíduo e de longa data era Carlos Pinheiro, poeta e blogueiro, morador das imediações do CEU, que mantinha 
uma relação bastante próxima com a coordenadora da biblioteca. ${ }^{154}$

Podemos procurar em certas características espaciais alguns motivos para o esvaziamento da biblioteca, ainda que sua capacidade explicativa seja evidentemente limitada. Algumas pessoas relataram que a biblioteca não é facilmente identificada como tal por estar dentro do CEU - e, mais especialmente, por fazer parte do volume do bloco educacional. Essa dificuldade refere-se à falta de destaque visual em relação ao resto do bloco e à associação precipitada que algumas pessoas fazem entre a biblioteca e as escolas.

Razões melhores para o esvaziamento da biblioteca podem ser localizadas entre as que identificamos acima para as bibliotecas dos CEUs em geral, somadas àquelas derivadas de dinâmicas interacionais do CEU Butantã, como vimos no capítulo anterior, as quais atravessam também as práticas cotidianas de sua biblioteca. Também aqui encontramos relações permeadas por dificuldades para a produção de deliberações coletivas, em grande parte oriundas de adesões e dissensões em relação ao valor do acolhimento. Disposições favoráveis ao acolhimento encontravam-se presentes sobretudo na atuação da coordenadora da biblioteca: durante a gestão de Marta Suplicy, ela chegou a integrar a equipe que concebeu o programa da área infantil das bibliotecas dos CEUs em geral, passando, em seguida, a assumir a gestão do equipamento do CEU Butantã durante a maior parte de seus dez anos de existência, inclusive durante a gestão de Anna Cecília Simões (2003-2004). Além da coordenadora, a biblioteca possuía em seu quadro funcional duas bibliotecárias subordinadas, uma assistente técnica de ensino (ATE) e uma funcionária de limpeza.

Durante o ano de 2013, atividades de formação foram concebidas e implementadas unicamente com o trabalho da coordenadora e da assistente técnica de ensino. Um sarau dedicava-se mensalmente a apresentar um lugar do mundo, através de uma seleção de informações, poesias e fotografias de viagens feitas por turistas. Alguns apresentadores integravam o público regular do evento - como eu próprio -, composto por uma média de dez a quinze frequentadores, muitos deles professores e funcionários do CEU e da Diretoria Regional de Ensino do Butantã. Carlos Pinheiro era o único morador do entorno que frequentava

\footnotetext{
${ }^{154}$ Eram provavelmente as turmas das escolas que elevavam as estatísticas de frequentação da biblioteca, fazendo-a alcançar a modesta cifra de 800 visitantes por mês, ou aproximadamente 33 por dia, incluindo os sábados - de acordo com avaliações feitas pela coordenadora para os meses iniciais de 2013. Essa cifra, que a julgar pelo que observei no cotidiano do CEU me parece exagerada, é comparada pela coordenadora da biblioteca ao quase meio milhão de habitantes da subprefeitura do Butantã e aos 5 mil visitantes mensais de uma biblioteca pública em que trabalhou anos atrás, no bairro de Pinheiros.
} 
assiduamente o sarau. Podemos destacar também a organização de algumas exposições ao longo do ano, em especial a de periodicidade anual, que apresentava trabalhos de alunos da EMEI. A coordenadora também promoveu encontros de incentivo à leitura com professoras da EMEI do CEU, entre outras atividades.

De resto, a relação entre os funcionários desta biblioteca mostrava-se marcada, muitas vezes, por uma escolha dicotômica entre o privilégio a "usuários" ou a "livros", de acordo com uma expressão que ouvi uma vez e que parece ilustrar muito bem o modo como o problema do acolhimento se colocava para os bibliotecários. Conforme afirmou a mim por diversas vezes, a coordenadora acredita que uma biblioteca de CEU deve privilegiar o "usuário", e os funcionários que trabalham num CEU deveriam ter um "perfil" orientado pela proposta inicial dos CEUs, fundamentada no "acolhimento". Sob seu ponto de vista, muitos dos bibliotecários que trabalham em CEUs têm uma formação tradicional em biblioteconomia, que privilegia a preservação e o cuidado com o acervo das bibliotecas, de tal forma que suas preferências terminavam por prejudicar a qualidade do atendimento ao público.

\subsection{Biblioteca do CEU Vila Rubi: "foco no social"}

A biblioteca do CEU Vila Rubi situa-se numa posição de destaque, no primeiro andar de um edifício localizado no cruzamento das duas ruas internas do centro educacional. O edifício tem forma cilíndrica e abriga também o telecentro, que faz divisa com a biblioteca no primeiro andar, e o refeitório central do CEU, que ocupa todo o térreo do referido edifício. ${ }^{155}$ As curtas distâncias em relação aos fluxos de circulação e aos outros edifícios do CEU trazem uma sensação de proximidade entre frequentadores do CEU e biblioteca, mas o fato de situar-se no primeiro andar impede a configuração de intensividades. Em outras palavras, a biblioteca pode ser perfeitamente evitada, e as pessoas que observam ou adentram o seu interior são praticamente apenas aquelas que se interessam pelo equipamento.

${ }^{155}$ Para o melhor entendimento destas relações, consultar as figuras 17 e 33, nos capítulos precedentes. 


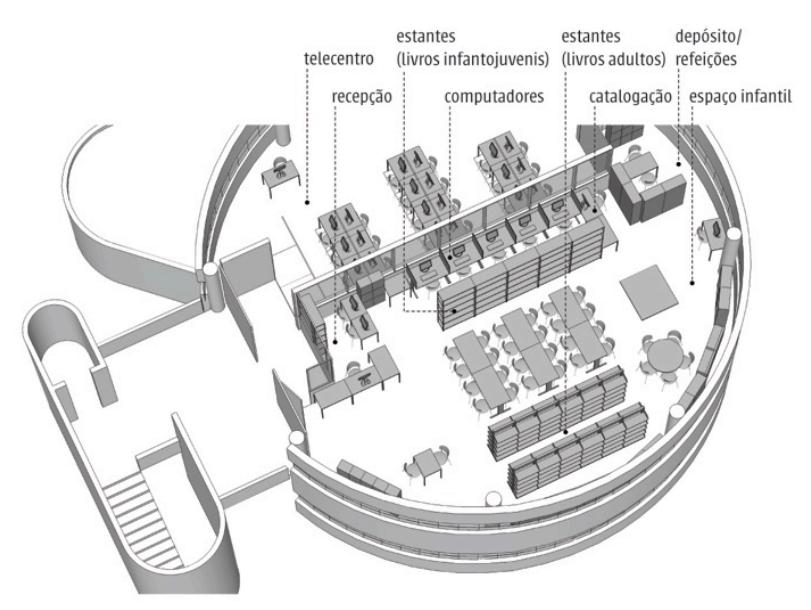

Figura 45 - Perspectiva da biblioteca do CEU Vila Rubi (2013).

O espaço interno da biblioteca configura-se em semicírculo, com uma parede curva dotada de janelas contínuas. No projeto original, as mesas de leitura localizam-se ao longo das janelas e o miolo da planta recebe estantes e áreas de trabalho dos bibliotecários. De um lado do espaço, o projeto de arquitetura havia definido acessos independentes à biblioteca e ao telecentro, e no lado oposto havia uma comunicação interna, semelhante à primeira, entre os dois equipamentos. A ocupação posterior preferiu desativar esta comunicação interna, colocando em seu lugar um pequeno espaço para depósito e refeições de funcionários, de modo a diminuir espaços de circulação em equipamentos com área já tão reduzida. Além disso, a presença das janelas no ambiente interno foi em grande parte preterida em função da disposição das estantes em suas proximidades, e o espaço principal, com mesas de leitura, deslocou-se para o interior da planta.

A biblioteca possui uma área de cerca de 100 metros quadrados, o que equivale a menos de um quinto da área da biblioteca do CEU Butantã. A exiguidade do espaço obriga seus frequentadores a otimizarem sua ocupação. Os usuários adultos concentram-se nas mesas do ambiente principal e nos computadores, e o público infantil é direcionado à área mais livre dos fundos da biblioteca. Oficinas e outros eventos acontecem por vezes na mesa mais próxima à porta de entrada ou nas mesas dos fundos; eventos de maior escala têm lugar simplesmente com a remoção das mesas de leitura. Os bibliotecários sentam-se na ilha de recepção para realizar quase 
todas as atividades, com exceção da catalogação, que acontece em uma mesa situada do outro lado da biblioteca.

Além de contar com espaços reduzidos, esta biblioteca contrastava com a do CEU Butantã por ser bastante procurada. A frequência intensa reforça a avaliação geral do CEU Vila Rubi como um equipamento de exceção em meio aos outros CEUs da cidade. Surpreendentemente, os bibliotecários responsáveis pelo equipamento não coordenam explicitamente suas ações com as dos gestores do CEU, não realizam reuniões de trabalho externas, nem compartilham objetivos ou projetos específicos com os gestores. Uma explicação plausível para a coincidência do sucesso das administrações da gestão e da biblioteca parece passar pela defesa do acolhimento como valor predominante, em meio a uma combinação bem-sucedida de contextos extensivos e parcelas menores de intensividades e separações, com veremos ao longo desta exposição.

As bibliotecárias deste CEU consideram que a frequência à biblioteca aumentou progressivamente conforme foram sendo implementadas ações de "marketing" e "projetos". A biblioteca adota canais variados de divulgação de suas atividades por meio da afixação de cartazes pelo CEU e da distribuição de filipetas com um resumo da programação mensal. Publicam-se também histórias e eventos em um blog e na rede social Facebook. E-mails de divulgação de chegada de novos livros atraem sempre alguns interessados. Observei uma forma particularmente interessante de "marketing", com a fixação de uma pequena mensagem na agenda dos alunos da EMEI, apontando brevemente para os benefícios da leitura e convidando os pais a visitarem a biblioteca com seus filhos. Este último canal de divulgação sugere a relação de vínculos ocasionais e voluntários entre diferentes equipamentos do $\mathrm{CEU}$, como as atividades efetivamente realizadas em parceria com as escolas, que mencionaremos logo a seguir.

Dentre as atividades espontaneamente realizadas pelos usuários destaca-se a leitura para o lazer, sobretudo por parte dos mais jovens. Havia também muita procura pelos computadores por parte de jovens e adultos, que preferiam os da biblioteca aos do telecentro devido à possibilidade de acesso a sites como o Youtube, e por conta da realização periódica de cursos de informática no telecentro. Alguns pais costumam retirar livros para ler com seus filhos em casa, como atividade recreativa ou para reforço escolar.

Além dessas atividades, diversos "projetos" são oferecidos regularmente pelo corpo de funcionários. A "Hora do Conto" existe desde 2009, recebendo as dezoito turmas de alunos de 
CEI e EMEI, em periodicidade mensal. Para esta atividade os bibliotecários revezam-se em nove contações diárias, ao longo de dois dias, cada um contando aproximadamente duas vezes uma mesma história. A "Mediação de Leitura" envolve atividades de incentivo à leitura, oferecidas com menos regularidade às turmas do ciclo Fundamental I da EMEF. "Rodas de Leitura" aconteceram em média bimestralmente em 2013, concentrando-se em discussões e leituras de livros para o vestibular, para grupos de aproximadamente meia dúzia de jovens. Às sextas-feiras e sábados, a "Recreação na Biblioteca" ofereceu às crianças, ainda durante o ano de 2013, jogos lúdicos e materiais para desenhos como forma de atraí-las para o espaço da biblioteca e eventualmente levá-las a se interessar pelos livros. Numa mesa próxima à entrada, exposições reuniam livros e informações sobre temas como o Dia da Consciência Negra, Dia do Índio, Carnaval e festas folclóricas. Antes da entrada da biblioteca, uma mesa oferecia ocasionalmente itens que não interessavam ao acervo da biblioteca. Outros eventos foram oferecidos diversas vezes ao longo do ano de 2013: oficinas de xadrez (que reuniam não mais de meia dúzia de crianças); "Entre as orelhas do livro" (que promoveram alguns encontros com autores de livros infantojuvenis); mesas de trocas de livros organizadas nas festas dos CEUs.

Fica claro que boa parte dessas atividades configura contextos intensivos que induzem as pessoas a frequentar o espaço da biblioteca: na medida em que as atividades despertam o seu interesse, as pessoas frequentam o espaço e terminam, assim, ampliando o contato umas com as outras, e também com outros serviços da biblioteca. Essa intensividade atenua o caráter fundamentalmente extensivo da biblioteca e combate mais particularmente a tendência de desaceleração das interações, característica das extensividades. ${ }^{156}$

Vale mencionar dois prêmios conquistados por esta biblioteca: ela ficou entre as dez finalistas do concurso nacional Prêmio Viva Leitura de 2012 e obteve o primeiro lugar no XI Prêmio de Biblioteconomia Paulista Laura Russo. Este último foi ganho com a apresentação de um artigo, escrito em conjunto pela equipe de bibliotecários, que procura relacionar o aumento da frequência à biblioteca com o sucesso de seus projetos internos.

$\mathrm{Na}$ biblioteca do CEU Vila Rubi o corpo de funcionários é composto por uma bibliotecária coordenadora e três bibliotecários subordinados, não havendo a presença de outros tipos de profissionais, como ocorre na biblioteca do CEU Butantã. As bibliotecárias também

\footnotetext{
${ }^{156}$ A indução de interações pela promoção de atividades que despertem o interesse das pessoas já foi observada como iniciativa de alguns gestores, no capítulo 2 .
} 
estabelecem diferenças entre bibliotecas que priorizam o atendimento do "público" e outras que envolvem uma quantidade maior de trabalhos técnicos. Existe uma adesão generalizada do grupo de funcionárias à primeira opção; nas palavras de uma delas, "prefiro muito mais trabalho com público do que com livro". É importante notar que ao menos duas bibliotecárias já haviam passado por trabalhos em que atendiam comunidades desfavorecidas; a chegada delas à biblioteca do CEU Vila Rubi foi em parte deliberada, como resultado de uma procura por bibliotecas que favorecem o "foco no social".

A semelhança com as palavras da coordenadora do CEU Butantã é nítida, mas não vemos aqui uma contraposição dicotômica e excludente, na ação delas, entre privilégio concedido a "usuários" ou a "livros": segundo as bibliotecárias, as regras existem para que o espaço seja respeitado. Nas palavras de uma delas, "o usuário respeita as regras porque sabe que, se desrespeitar, quem vai perder é ele". Assinala-se assim a proliferação de várias regras de utilização, que estabelecem uma certa relação de hierarquia entre bibliotecárias e usuários, na medida em que as primeiras são detentoras do poder de fazer cumprir as regras. Mas estas tendem a funcionar mais como intensividades que forçam alinhamentos entre bibliotecárias e usuários, e menos como separações, porque os usuários não deixam de estar no primeiro plano das preocupações. As regras podem ser empregadas num sentido que se opõe às ideias de extensividade e de convencimento, mas não são exercidas num sentido de punição ou de evitação de danos ao acervo. Já observamos como as carteirinhas implementadas pelo gestor deste centro educacional não adquiriram um sentido de impedimento do acesso, mas de garantias àqueles localizados em seus espaços interiores; no caso da biblioteca do CEU Vila Rubi, as mesmas mudanças de sentido produzidas com escolhas de palavras, gestos e entonações de voz mostramse decisivas para modificar a conotação geralmente associada a controles. Enfim, a existência de regras e de atividades que, para serem usufruídas, demandam interação mostra que esta biblioteca contou com parcelas menores de intensividades e separações para combater os pontos fracos das extensividades.

\subsection{Recepção}



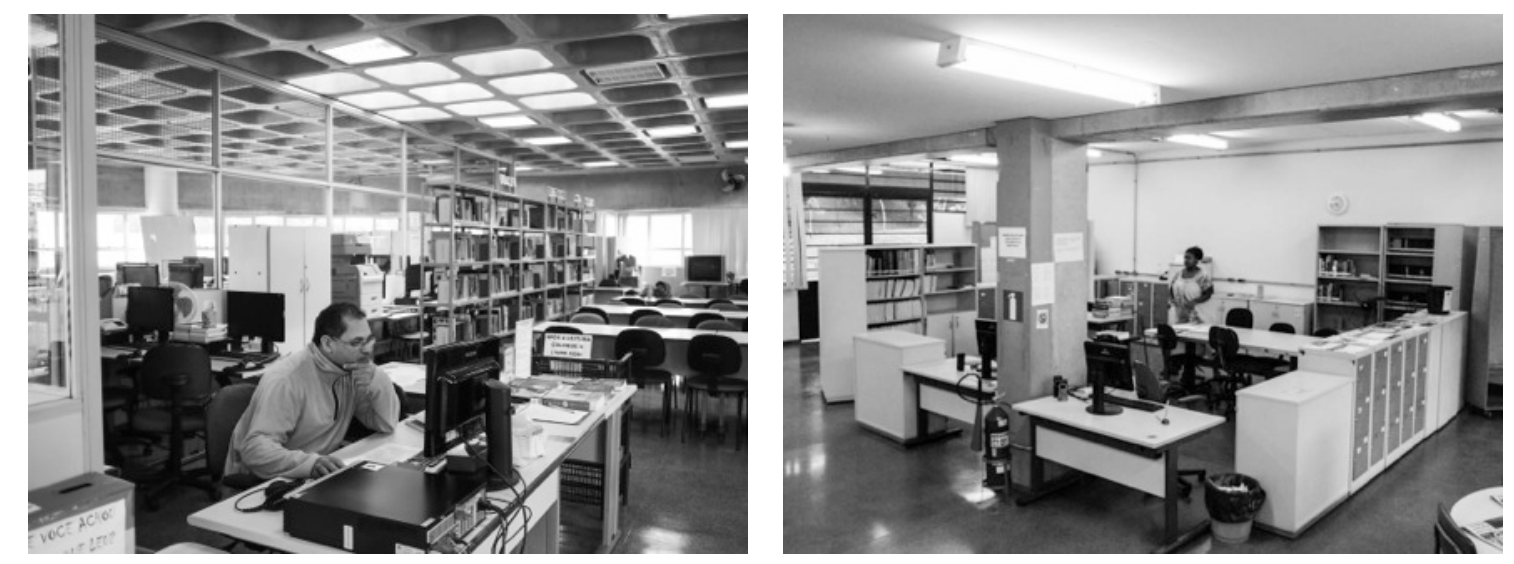

Figuras 46 e 47 - Espaços de recepção dos CEUs Vila Rubi (à esquerda) e Butantã (à direita).

Passemos agora a problematizar a relação entre interações e contextos por meio de uma análise mais pormenorizada de quatro espaços das bibliotecas, a começar pela recepção. Este primeiro ambiente é de preocupação prioritária das bibliotecárias e nunca pode estar desatendido: é aí que se faz a triagem do que chega do exterior e do que sai do interior da biblioteca. ${ }^{157}$ Controles de acesso, cadastros e empréstimos precisavam de contextos intensivos na forma de normas e espaços, graças aos quais se garantia a proximidade entre funcionários e usuários.

Nas figuras 43, 47 e 49, relativas à biblioteca do CEU Butantã, pode-se observar uma série de armários baixos dispostos de modo a configurar um gargalo espacial, com o objetivo de obrigar o visitante a passar em frente ao funcionário da recepção. Esse esforço de indução de interações humanas não se fez necessário na biblioteca do CEU Vila Rubi, certamente porque seu espaço exíguo já configurava, por si só, um gargalo - conforme mostra a figura 46 acima.

No âmbito das normas, problemas com cadastro configuravam contextos intensivos que vinham somar-se à intensividade espacial supracitada. Na recepção da biblioteca do CEU Butantã a já mencionada dicotomia entre usuários e livros tomava a forma, por exemplo, da discussão em torno da exigência de cadastro como condição para realização de empréstimos. Por exemplo, quando algumas professoras do CEU participaram de um curso na biblioteca e manifestaram interesse em emprestar alguns materiais, a coordenadora revelou o desejo de realizar o empréstimo sem cadastro. Seu interesse era o de não perder a oportunidade de incentivar a prática

\footnotetext{
${ }^{157}$ A impossibilidade de deixar a recepção desatendida obriga a biblioteca a ter sempre dois funcionários presentes, pois quando há apenas um, ficam impedidas as idas ao banheiro, dentre outras ações.
} 
da leitura, considerando que o cadastro impediria o empréstimo naquele momento, e que as professoras dificilmente voltariam a procurar a biblioteca no futuro. Este foi um dos pontos de divergência entre ela e outra funcionária, que demonstrou uma maior preocupação para com o controle e a preservação do acervo, sendo contrária ao empréstimo sem cadastro.

$\mathrm{Na}$ biblioteca do CEU Vila Rubi, por sua vez, presenciei considerações a respeito da possibilidade de empréstimos de revistas sem exigência de cadastro aos salva-vidas da piscina, sob a justificativa de que eles passariam muitas horas ociosos. Mas as bibliotecárias também atribuíram grande importância ao cadastro, vinculando-o à emissão de uma carteirinha feita sob a condição de apresentação de um comprovante de residência. Assim, foi mais difícil encontrar, nesses relatos, a presença de uma dicotomia entre privilégio a usuários e preservação do acervo.

Passemos a uma discussão em torno de critérios para suspensão de usuários. Certa vez, uma das bibliotecárias do CEU Butantã sugeriu proibir um usuário de realizar empréstimos de revistas depois que ele devolveu um exemplar com a capa rasgada, por tê-lo guardado indevidamente em sua mochila. A coordenadora, por outro lado, procurou observar que a rotina daquele usuário era difícil, que ele tinha problemas de saúde, e que pessoas nas suas condições podiam eventualmente descuidar de precauções com seus pertences. Este seria, a seu ver, o público que o CEU deveria atender, e por isso mesmo as normas de uma biblioteca de CEU não deveriam ser aplicadas com rigor. Quando uma das bibliotecárias voltou a insistir na importância das normas, a coordenadora respondeu em tom irônico: "vocês criam a norma, eu cuido da exceção". Podemos observar, neste caso, que o termo exceção equivale a acolhimento, e que estamos diante de uma reposição particular da dicotomia entre privilégio a usuários ou a livros. Por outro lado, na biblioteca do CEU Vila Rubi, as bibliotecárias comentaram com naturalidade a solução dada para o caso de um jovem que tinha perdido a capa de uma revistinha: pediam que ele repusesse com outra, trazida de sua casa. O mesmo valia para a perda de livros, e aí não havia preocupação em repor exatamente o mesmo título; ou seja, a preocupação com a reparação do acervo não chegava a ser minuciosa. 

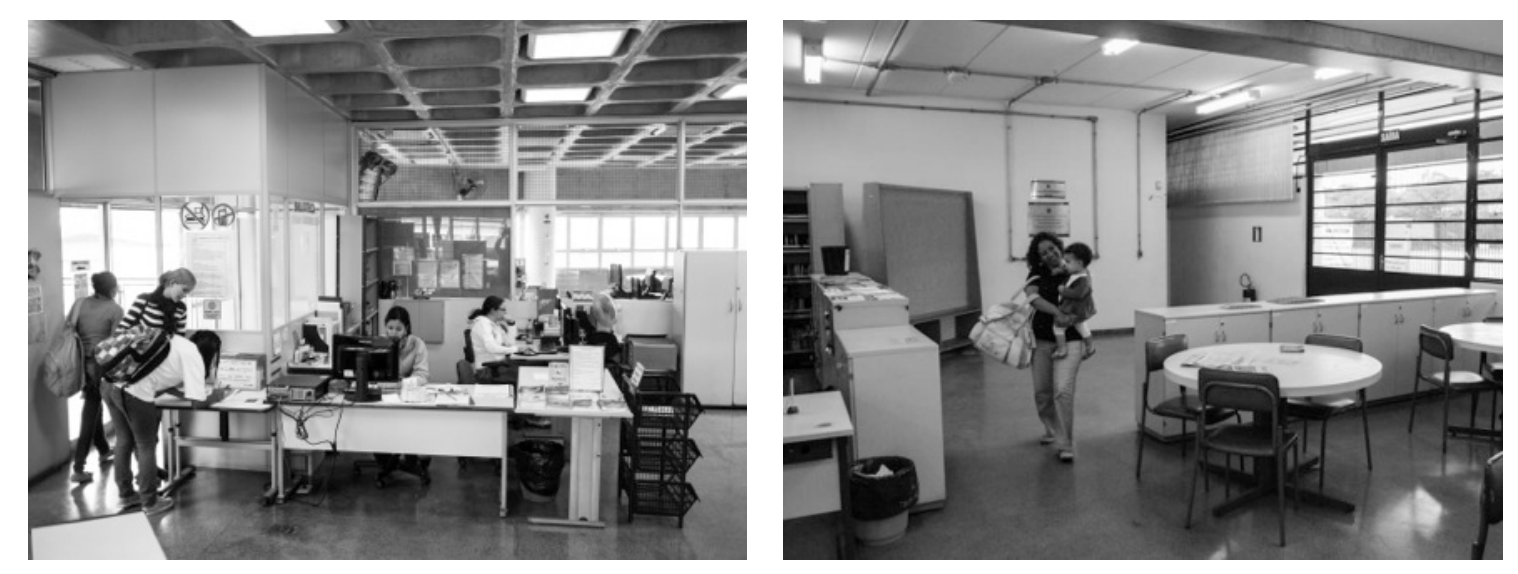

Figuras 48 e 49 - Controles de acesso às bibliotecas dos CEUs Vila Rubi (à esquerda) e Butantã (à direita).

Tão importante quanto a regulação da saída de acervos era a questão da entrada de pessoas. Tanto a coordenadora da biblioteca do CEU Butantã quanto as bibliotecárias do CEU Vila Rubi acreditavam na importância de cativar o usuário. Do ponto de vista da primeira, "não basta abrir a porta, tem que chamar para entrar; não basta apenas oferecer um serviço". ${ }^{158} \mathrm{O}$ funcionário da biblioteca teria que ser um "facilitador", "senão a população não vem mesmo". Do ponto de vista das segundas, atuar nas "periferias" exigiria a consciência de que "só o fato de ter o espaço não significa que o público vai saber usar".

Se há interesses comuns de incentivo à frequência, existem diferenças entre as duas bibliotecas quanto aos critérios mais ocasionais para impedir o acesso. Isso aparece na preocupação com o risco de entrada de formas de sociabilidade conflituosas e assimétricas, frequentes nos ambientes escolares dos CEUs. Certa vez, uma educadora da EMEF do CEU Butantã solicitou à coordenadora que chamasse a atenção de alunos que estivessem "fazendo hora" na biblioteca, demorando para reagir ao sinal de aviso do início das aulas. A coordenadora considerou a atitude sugerida incompatível com o caráter de livre acesso característico de uma biblioteca. Se esse transbordamento dos códigos de comportamento escolar tendia a ser encarado, no CEU Butantã, como um problema entre funcionários com posições inconciliáveis, no CEU Vila Rubi o assunto ganhava conotação mais pragmática, mostrando-se como uma questão a ser

\footnotetext{
${ }^{158}$ A afirmação foi feita como uma crítica à determinação de uma ex-gestora do CEU Butantã, que anos atrás teria determinado que a biblioteca abrisse aos domingos, sem levar em conta a alta probabilidade de que não houvesse usuários nesse dia da semana. No entender da coordenadora da biblioteca, a abertura aos domingos demonstrava haver uma preocupação primordial com "números e fotos", ou seja, com a visibilidade política das decisões, e não com o interesse efetivo na promoção do acolhimento.
} 
enfrentada por meio de interações entre bibliotecárias e alunos. Para evitar tumultos praticados por alunos das escolas, as bibliotecárias não hesitavam em proibir a entrada de grupos que estivessem em intervalos de aula, porque eles iriam "só para zoar", ficariam correndo, mexendo em vários livros, para logo depois ir embora. As bibliotecárias pediam a esses alunos que viessem antes ou depois do horário de aula; no entanto, permitiam o acesso àqueles que chegavam com a carteirinha, individualmente, dando mostras de que precisavam retirar livros para realizar trabalhos escolares. Novamente, temos aqui um critério misto, variável de caso a caso, que ora estabelecia regras capazes de proteger o ambiente interno e o acervo da biblioteca, ora reconhecia a necessidade do usuário em detrimento da aplicação da regra.

É importante observar que contextos separadores representados por impedimentos de acesso são vistos como recursos de poder eficazes na biblioteca do CEU Vila Rubi, enquanto a coordenadora do CEU Butantã tende a conferir um peso maior às extensividades e à ideia do livre acesso. De um modo geral a coordenadora não deixava de reconhecer a importância de normas e regulamentos, distanciando-se de posições mais radicais que invariavelmente preferiam saídas dialogadas - como vimos no caso da ex-gestora do CEU Butantã, Anna Cecília Simões. Mas na biblioteca do CEU Butantã o decisivo para a constituição das interações cotidianas era a polarização dos valores da coordenadora e das bibliotecárias subordinadas; as preferências secundárias e eventuais convergências de uma e outras não figuravam no primeiro plano.

\subsection{Computadores}

Na biblioteca do CEU Butantã, os computadores localizam-se numa posição subordinada e periférica em relação ao espaço de leitura, estando distantes dos olhares das bibliotecárias -

como podemos ver na figura 43. É possível que essa distância suscite preocupações e esteja envolvida com certas atitudes inibidoras da utilização desses equipamentos. $\mathrm{O}$ relato de um morador de uma comunidade vizinha ao CEU oferece detalhes de como as regras de utilização dos computadores funcionaram como contextos separadores que afastaram usuários do equipamento. O morador alegou a mim ter procurado o computador durante vários dias seguidos, 
mas em todos eles foram-lhe exigidos, na recepção, documentos que comprovassem sua identidade, como se ele não tivesse sido visto no dia anterior. Além disso, a bibliotecária da recepção perguntava sobre o propósito de utilização do equipamento, já que no entender de algumas delas o computador de uma biblioteca só poderia ser utilizado para "pesquisas". Em uma das ocasiões, depois de declarar sua intenção de "pesquisar", foi-lhe perguntado o assunto de sua pesquisa, e ele respondeu, já sem paciência, que não sabia o assunto e que justamente por isso precisava realizar a pesquisa. A animosidade entre a bibliotecária e o morador mencionado mostra como as normas de funcionamento configuram contextos separadores - e não intensivos, como veremos no caso da biblioteca do CEU Vila Rubi - que afastaram certos usuários da biblioteca. Isso fica claro se considerarmos que, na biblioteca do CEU Butantã, são as bibliotecárias subordinadas que se responsabilizam pelo atendimento ao público, estando a coordenadora dedicada a outros trabalhos. ${ }^{159}$
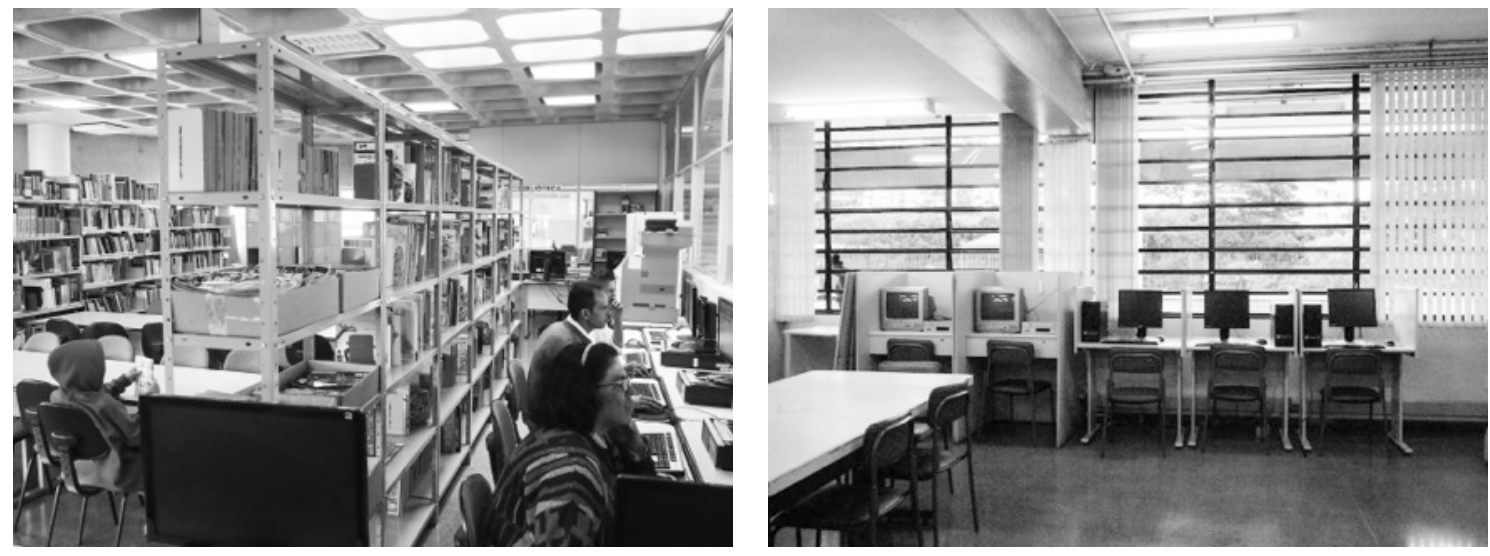

Figuras 50 e 51 - Espaços dos computadores. No CEU Vila Rubi (à esquerda) as estantes infantojuvenis separam usuários de computadores do ambiente de leitura. A imagem da direita retrata o espaço dos computadores na biblioteca do CEU Butantã.

Quando discutiam sobre o uso dos computadores, as bibliotecárias subordinadas diziam que sites como o Facebook, por exemplo, deveriam ser proibidos, já que estariam associados apenas ao entretenimento e a conteúdos desimportantes. Sob seu ponto de vista, o computador sequer seria muito indicado para a realização de pesquisas, já que os livros tendiam a ser vistos como mais qualificados e confiáveis do que a Internet. Um tom acusatório foi por vezes usado

\footnotetext{
${ }^{159}$ Essa divisão de tarefas é determinada pelo segundo regimento interno dos CEUs (SÃO PAULO, 2006), mas na biblioteca do CEU Vila Rubi não é adotada, como veremos mais adiante.
} 
para condenar uma prática de alunos, que consistiria em duplicar conteúdos da Internet em arquivos do programa de edição de texto, para trabalhos escolares - com os livros, isso não seria possível. Por sua vez, a coordenadora da biblioteca é favorável ao acesso ao site Facebook e à Internet em geral, pelo mesmo motivo pelo qual defende a aquisição de itens de acervo variados, incluindo-se alguns dos mais populares e de qualidade mais duvidosa: para ela, essas atrações podem funcionar como "porta de entrada" para outros assuntos. Nesse sentido, a "porta de entrada" produziria uma intensividade capaz de atrair usuários para a utilização da biblioteca, mas medidas como essas não conseguiam ser implementadas por conta das discordâncias entre as bibliotecárias.

Esta discussão mostra que a ausência de normativas mais específicas de trabalho e a desconsideração das já existentes - que determinam hierarquias de poder - tendem a produzir contextos extensivos nas interações entre colegas de um mesmo equipamento. Na extensividade, desacordos podem fazer com que cada funcionária adote suas próprias regras, prejudicando a percepção de coerência da equipe. Mudanças neste quadro só podem acontecer se contarem com a vontade deliberada das pessoas; sendo assim, a situação pode persistir indefinidamente. Enfim, somando-se as separações entre público e biblioteca, e as extensividades entre bibliotecárias, temos dinâmicas interacionais sujeitas a uma forte desaceleração.

A produção de desacelerações através de uma combinação de desacordos, extensividades e separações também foi encontrada no âmbito da gestão do CEU Butantã. Chegamos a considerar que as parcelas mínimas de intensividade ali presentes, representadas pelos vínculos empregatícios entre funcionários, poderiam produzir acomodações de parte a parte, envolvidas na produção gradual e não deliberada de um mínimo de consensos. No caso da biblioteca do CEU Butantã, acomodações acontecem com mais dificuldade, porque as funcionárias pertencem a um mesmo equipamento e precisam conviver diariamente. No entanto, essa intensividade é em grande medida atenuada com a constituição de espaços próprios de trabalho (como veremos mais adiante) e com a definição de turnos de trabalho que minimizam as interações interpessoais. Isso mostra como a intensividade no âmbito dos vínculos empregatícios pode ser atenuada por extensividades produzidas no âmbito do espaço e do tempo. Enfim, existe na biblioteca uma parcela maior de intensividade em relação àquela existente entre diferentes equipamentos do centro educacional, e, apesar de isso relacionar-se com a persistência de desconfortos mútuos, não chega a alterar a predominância de extensividades e separações. 
A biblioteca do CEU Vila Rubi, por sua vez, possuía cinco computadores destinados aos usuários, sendo a utilização e regulação desse uso bastante intensas. O controle era facilitado em grande medida pelo posicionamento de uma série de estantes de livros infantojuvenis logo atrás das mesas com computadores, de modo a formar um estreito corredor, cujo acesso dava-se unicamente por uma passagem lateral à ilha da recepção. A série de estantes foi deliberadamente posicionada para controlar a utilização dos computadores; nesse sentido, configura um contexto separador. Segundo uma das bibliotecárias, um segundo acesso teria existido na outra extremidade do corredor, mas foi fechado com o posicionamento da mesa de catalogação porque alguns jovens "ficavam dando voltas por ali e dificultavam o controle". Assim, na maior parte do tempo, o funcionário da recepção consegue controlar o uso dos computadores monitorando o gargalo de acesso ao corredor e a lista de inscrição.

No CEU Vila Rubi, as normas que reforçavam a intensividade espacial do corredor dos computadores eram bastante detalhadas, e poderiam atuar como cerceadoras do uso das máquinas caso as palavras e o tom de voz escolhidos pelas bibliotecárias não transmitissem uma conotação muito diferente daquela adotada por algumas das bibliotecárias do CEU Butantã. Por exemplo, a utilização dos computadores era vetada a usuários com menos de 14 anos, de modo a evitar jogos eletrônicos. Apenas uma pessoa por vez podia usar o computador, já que, de acordo com uma das bibliotecárias, quando dois jovens sentavam-se para utilizar a mesma máquina, havia risco de barulho e confusão. E o tempo de uso era controlado por uma lista de frequência que comumente se transformava em lista de espera. Mesmo assim, havia possibilidade de incômodos; certa vez, quando um usuário recusou-se a colaborar, foi convidado a sair da biblioteca: "pode levantar e sair", disse uma das bibliotecárias. Com estas palavras de ordem, um jovem raramente resistia; elas representam um dispositivo discursivo que, mesmo raramente empregado, mantinha-se como possibilidade, de modo a inclinar o usuário na maior parte das vezes a obedecer o funcionário. ${ }^{160}$

Na biblioteca do CEU Vila Rubi, a liberação de acesso ao site do Facebook trouxe um incremento significativo ao número de visitações, tal como sugerido pela coordenadora da biblioteca do CEU Butantã. Mas o tempo de utilização das máquinas era modulado em função

\footnotetext{
${ }^{160}$ No CEU Vila Rubi, a prática de convidar usuários a se retirarem foi observada por mim não apenas na biblioteca, mas também durante apresentações artísticas promovidas pelos gestores, no teatro do centro educacional. Certas vezes o convite era colocado como possibilidade, e mesmo sem ser efetivado funcionava como uma ameaça capaz de suscitar obediência. Seria interessante observar se não se trata aqui de um recurso oriundo do universo da educação e de práticas de professores em salas de aula.
} 
disso: um máximo de 30 minutos para aqueles que acessam a rede social, e de 60 minutos para outros usos. As bibliotecárias tinham condições de fazer essa discriminação porque conheciam os hábitos de seus frequentadores. Quando flagravam uma utilização conflitante com a declaração, davam "broncas" e podiam até suspender o usuário, fazendo uso de outro dispositivo drástico capaz de produzir os mesmos efeitos do convite à retirada. Uma das preocupações diante de suspensões era comunicar o fato aos outros bibliotecários, de modo que todos referendassem as mesmas decisões perante o público. Esse espírito de equipe, precário no CEU Butantã, era considerado bastante importante pelas bibliotecárias do CEU Vila Rubi. Segundo elas, as crianças contestam a efetivação de uma proibição recorrendo a funcionários diferentes daquele que a aplicou.

\subsection{Estantes}

No CEU Vila Rubi, as estantes estavam localizadas em lados opostos do espaço das mesas de leitura, como mostra a figura 45. De um lado encontravam-se as estantes com conteúdos juvenis e infantis que, como já vimos, separavam os computadores do resto da biblioteca; de outro estavam as estantes com conteúdos para adultos. Um dos propósitos da separação dos conteúdos das estantes por interesse de faixa etária era inibir tumultos no interior da biblioteca. De acordo com o relato das bibliotecárias, quando as crianças dirigiam-se aos corredores entre as estantes de adultos, ficava evidente que queriam "ficar escondidas" ou "aprontar". Quando advertidos, os usuários costumavam dizer que estavam procurando um livro, e a separação dos conteúdos permitia às bibliotecárias interpelarem as crianças com mais argumentos, já que ali não haveria livros de seu interesse. Mas isso podia ser pouco para contêlas.

Outro recurso considerado insatisfatório pelas bibliotecárias era tentar uma aproximação, pois as crianças ficavam dando voltas ao redor das estantes, sendo impossível alcançá-las: "vira um pega-pega". Nos casos mais complexos, a solução exigia uma medida drástica e efetiva: a bibliotecária trancava a porta da biblioteca, ia até uma mesa de leitura e mandava as crianças se 
aproximarem, ameaçando mantê-las trancadas ali enquanto ela se dirigisse à diretoria da escola para convocar os pais para uma conversa.
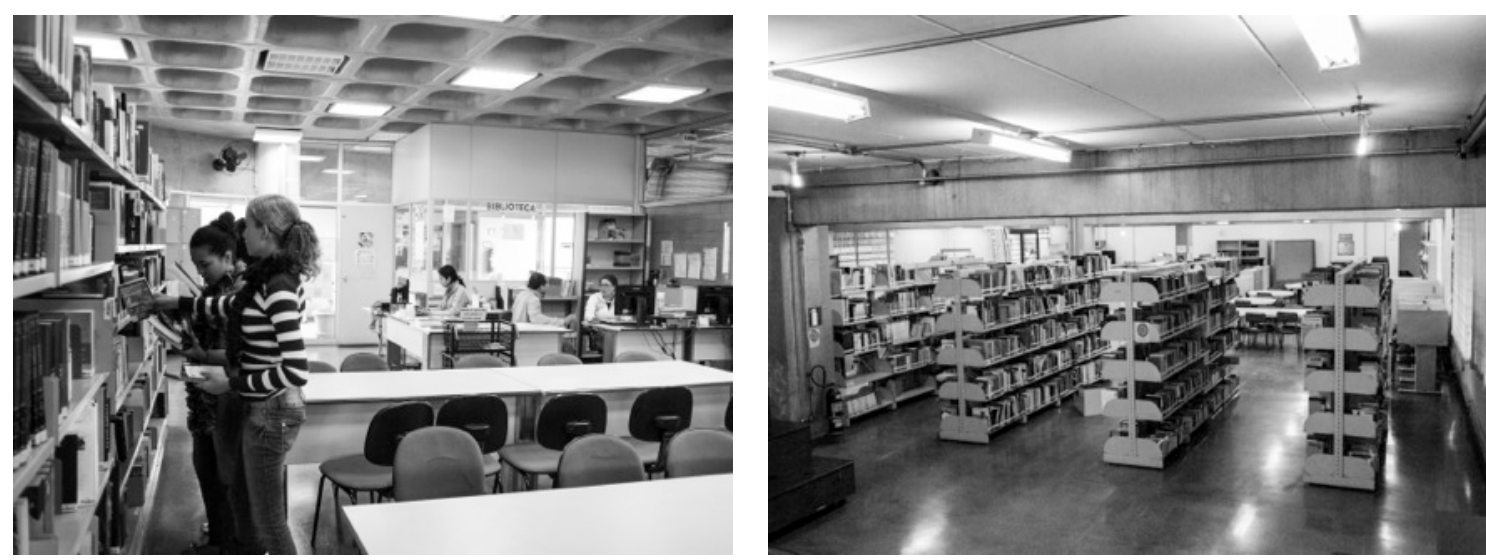

Figuras 52 e 53 - Estantes. Na imagem do CEU Vila Rubi (à esquerda), vê-se a entrada e a recepção ao fundo. No CEU Butantã (à direita), as estantes formam diversos corredores e caminhos.

No CEU Butantã havia um número maior de estantes, distribuídas de acordo com distâncias e alinhamentos variados, como mostram as figuras 43 e 53. A disposição era considerada confusa por vários usuários e funcionários com quem conversei. Ao tentar explicar o posicionamento das estantes, a coordenadora observou que elas ficaram nos lugares "que sobraram", tendo em vista as necessidades dos outros ambientes. Mas com uma quantidade de espaço tão maior do que aquele disponível na biblioteca do CEU Vila Rubi, como se explica o posicionamento das estantes como resultado de uma sobra? Parece claro que, neste nível da análise, não podemos concluir que a área da biblioteca do CEU Butantã era grande, nem em termos absolutos, nem em comparação com a biblioteca do CEU Vila Rubi. Porém, o modo como os espaços são praticados e entendidos pelas pessoas é decisivo nesse caso. Desenvolveremos melhor este ponto no próximo item.

Confusões causadas por visitas ocasionais de jovens e crianças também aconteciam na biblioteca do CEU Butantã, mas neste caso não havia soluções evidentes. ${ }^{161}$ Pude testemunhar os esforços pouco efetivos de funcionárias que, procurando se fazer ouvir, andavam atrás dos jovens ao redor das estantes, sem conseguir alcançá-los. Tanto a ausência de represálias estabelecidas

\footnotetext{
${ }^{161}$ Acontecimentos desse tipo suscitaram o seguinte comentário irônico de uma ex-gestora do CEU à coordenadora da biblioteca: "no CEU não tem o Menino Jesus".
} 
como, no âmbito do espaço, os caminhos mais longos e variados proporcionados pela amplitude do espaço e pelo excesso de corredores entre as estantes conformavam um contexto extensivo, garantindo aos jovens uma singular facilidade de evitar confrontos com as bibliotecárias. Mas, como vimos, isso também acontecia no espaço exíguo da biblioteca do CEU Vila Rubi, porque a presença das estantes atuava como uma espécie de fator multiplicador do tamanho do espaço, no que concerne às chances de evitar interações interpessoais. Para evitar o confronto com as bibliotecárias, mesmo no espaço de 100 metros quadrados da biblioteca do CEU Vila Rubi, bastava aos jovens dar voltas em torno das estantes. Poderíamos dizer que essa prática de espaço, para os propósitos aqui apontados, equivale a uma prática de fuga em campo aberto; conforme as palavras da bibliotecária do CEU Vila Rubi, "você não consegue alcançá-los". Esse é o melhor exemplo para ilustrar como contextos extensivos podem ser formados não só por lugares amplos, mas também por certas barreiras de espaço.

Na biblioteca do CEU Butantã as dificuldades em lidar com os jovens circulando ao redor das estantes sugerem uma sobreposição de extensividades no âmbito das normas e do espaço. Na biblioteca do CEU Vila Rubi, por sua vez, os fatos acima descritos mostram uma rara dinâmica de interações sucessivas, ao longo das quais contextos diferentes eram acionados em um mesmo espaço e em uma mesma interação: em primeiro lugar, temos um contexto separador de públicos em função da organização das estantes em dois lugares diferentes, por faixa etária. Além disso, as estantes configuravam o contexto extensivo da fuga em campo aberto. Finalmente, a bibliotecária acionava um forte contexto intensivo, fechando a porta da biblioteca para obrigar as crianças a confrontá-la.

\subsection{Catalogação}

Dentre os trabalhos técnicos de competência de um bibliotecário estão o recebimento, a classificação e a etiquetagem de novas aquisições da biblioteca. A precisão e atenção exigidas por essas atividades podem inspirar preocupações maiores ou menores dos profissionais que as 
realizam, e essas preocupações alteram significativamente a configuração desses espaços de trabalho.
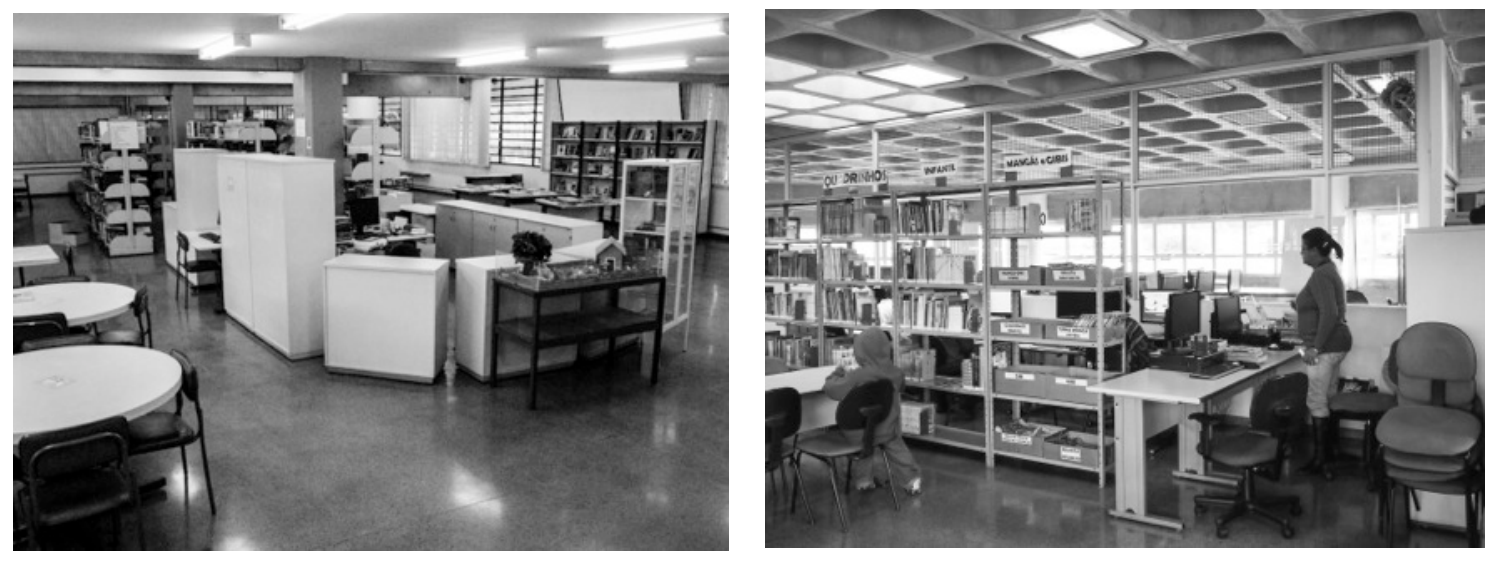

Figuras 54 e 55 - Catalogação. Na imagem do CEU Butantã (à esquerda), diversos armários formam um espaço separado, tendo as mesas de leitura à esquerda e as estantes ao fundo. $\mathrm{Na}$ imagem do CEU Vila Rubi (à direita), a mesa de catalogação avizinha-se do corredor de computadores e das estantes infantojuvenis.

Na biblioteca do CEU Vila Rubi a catalogação era feita na própria ilha da recepção, mas o atendimento aos usuários atrapalhava a realização da tarefa. Por conta disso, uma mesa exclusiva para esta atividade foi posicionada nos fundos da biblioteca. ${ }^{162}$ As bibliotecárias procuraram o máximo de distância espacial que foram capazes de conseguir em relação ao movimento de pessoas da entrada. Essa distância, somada ao obstáculo físico representado pelas cadeiras e mesas de leitura, compunham uma tímida configuração separadora entre usuários e funcionários, de modo que estes últimos possuíam uma certa margem de manobra para evitar ou filtrar interações. ${ }^{163}$

O trabalho de catalogação na biblioteca do CEU Vila Rubi é de responsabilidade de todos os funcionários, pois eles se revezam por todas as funções internas da biblioteca, de acordo com

\footnotetext{
${ }^{162}$ Posteriormente, essa mesa foi deslocada para a vizinhança das estantes de livros infantojuvenis, de modo a impedir o acesso secundário ao corredor dos computadores, como vimos anteriormente.

${ }^{163}$ Mais forte que essa separação, mas não menos suscetível de preocupações, era aquela alcançada com a colocação de uma série de armários altos nos fundos da biblioteca, graças aos quais as bibliotecárias podiam guardar alguns objetos e realizar suas refeições. Mesmo assim, as bibliotecárias alegaram não se sentirem confortáveis, porque continuavam adivinhando o que estava acontecendo do outro lado dos armários em função do que eram capazes de ouvir. Lá "a gente não desliga", conforme o relato de uma delas, que dizia comer pressentindo o risco de ser chamada para auxiliar um colega ou usuário. Com isso podemos perceber o grau da força intensiva que existe no espaço dessa biblioteca. Vemos também como os fechamentos de espaço, como contextos separadores, são fundamentais em muitas situações, para a garantia da privacidade e da autonomia dos funcionários perante os seus públicos.
} 
uma distribuição semanal de horários. ${ }^{164}$ Portanto, todos os bibliotecários exercem sua parcela de influência sobre a configuração de cada um dos espaços de trabalho. O compartilhamento de tarefas, e o consequente compartilhamento dos lugares em que essas tarefas se realizam, são fatores indutores de negociações diversas entre os bibliotecários; formam, portanto, uma intensividade.

Já na biblioteca do CEU Butantã há trabalhos que são de responsabilidade exclusiva de certas funcionárias. Os lugares destinados à realização desses trabalhos são predominantemente configurados em função das exigências definidas por essas funcionárias em particular; com o tempo, esses espaços terminaram representando essas pessoas, confundindo-se com elas. $\mathrm{O}$ fato trazia uma nova camada de significados, que vinha se sobrepor de modo complexo àqueles associados mais diretamente às atividades propriamente ditas. Assim, a sala destinada à coordenação da biblioteca era de uso exclusivo da coordenadora e o espaço de catalogação, que nos interessa agora, de uso exclusivo das duas bibliotecárias subordinadas.

A análise realizada das estantes nos levou à constatação de que muitas características objetivas dos espaços podem não condizer com o modo como eles são praticados ou entendidos. O mesmo acontece com o espaço de catalogação: apesar da amplitude espacial original da biblioteca, o espaço de catalogação era visto por suas responsáveis como muito mal localizado, "socado aí no meio". A decisão pelo posicionamento centralizado da ilha de catalogação, segundo a coordenadora, dataria de muitos anos atrás e decorreria da disponibilidade de tomadas para os computadores, situadas nas laterais do pilar do local. Consequentemente, a ilha possuía vizinhos por toda a sua volta, o que dificultaria a realização do trabalho de catalogação, pelos motivos alegados a seguir.

Primeiramente, por parte das bibliotecárias subordinadas, haveria uma necessidade de silêncio e privacidade, que se mostrou sensível até mesmo ao "transitar em volta" das pessoas. Muitos usuários agiriam como se a pessoa diante do computador não estivesse trabalhando (não haveria essa associação entre trabalho e computador); além disso, haveria aqueles que chegam para conversar como se fossem íntimos, "pensam que a gente é psicólogo". A coordenadora da biblioteca, por sua vez, procurou salientar a necessidade de adaptação às especificidades de trabalho no $\mathrm{CEU}$, lembrando que o usuário "não pode atrapalhar o trabalho, porque ele é o

${ }^{164}$ A biblioteca do CEU Vila Rubi não segue exatamente as diferenças de atribuição entre bibliotecários coordenadores e bibliotecários subordinados determinada pelo segundo regimento interno dos CEUs. 
trabalho". Em segundo lugar, as bibliotecárias subordinadas salientaram os riscos da interrupção do trabalho de catalogação por parte dos usuários. Os erros produzidos seriam difíceis de reparar, podendo até mesmo passar despercebidos. Interrupções aconteceriam mesmo quando as bibliotecárias não estivessem ocupadas com a catalogação, já que as pessoas poderiam mexer nas pilhas de livros que muitas vezes ficam à espera da conclusão de procedimentos, por conta, por exemplo, da demora para se concluir a inserção de dados junto ao banco de dados on-line das bibliotecas, chamado Alexandria. Como resultado, as bibliotecárias responsáveis pela catalogação foram agregando armários baixos ao redor de seu espaço de trabalho, e substituindo alguns deles por armários altos: foram, assim, "se encastelando" em seus postos de trabalho. Essa expressão, aliás, evidencia o desdobramento, no âmbito simbólico do espaço, das divergências internas e das distintas concepções de serviço público que subordinadas e coordenadora possuíam.

A sala da coordenação funcionava como contraponto ao espaço de catalogação. Segregada dos espaços comuns, era apontada como um privilégio e como um reforço de hierarquias de poder que, aos olhos das bibliotecárias subordinadas, estariam em desacordo com a "filosofia de conversa" que teria orientado a criação dos CEUs. Segundo a visão de uma delas, os CEUs foram criados dentro de um pressuposto de diálogo que ainda não se teria efetivado, "nem de cima para baixo, nem de baixo para cima, nem da esquerda para a direita", e assim por diante. Nessa argumentação vemos uma apropriação bastante particular do tema do acolhimento, que aqui parece entendido como uma forma de questionar hierarquias de trabalho - jogando, se pudermos dizer, os feitiços do acolhimento contra os feiticeiros responsáveis por sua implementação. Em nossos termos, podemos dizer que o acolhimento pressupõe relações de diálogo e mútuo entendimento, mas não necessariamente implica na relativização de assimetrias de poder ou na ausência de interações de tipo não voluntário.

$\mathrm{Na}$ verdade, a insatisfação particular acima exposta inseria-se num quadro mais amplo de reclamações de muitos bibliotecários de CEUs com relação a extensividades mais amplas e não planejadas, relativas à falta de regulamentação e reconhecimento de seu trabalho de um modo geral - fosse por parte dos últimos governos municipais, fosse por parte da Secretaria de Educação, à qual estão subordinados. Do ponto de vista da coordenadora da biblioteca do CEU Butantã, essa ausência de orientações está na origem de comportamentos não compatíveis com o acolhimento, já que, segundo ela, as pessoas "são soltas pelo CEU" e com isso "começam a achar" como as coisas são, desconsiderando os princípios que deveriam nortear suas ações. 
A situação faz, ainda, com que muitos bibliotecários de CEU prefiram desincumbir-se de boa parte de suas responsabilidades como meio de expressar sua insatisfação. Mas se trata de uma forma de protesto velada e ambígua, sujeita a más interpretações, e que não parece contribuir para o progresso da deliberação coletiva. Situação semelhante foi encontrada quando observamos que certas ausências de participação no conselho gestor do CEU eram formas de protestar e contestar a autoridade dos gestores, caso em que também havia confusões de sentido que podiam relacionar a ausência ao desinteresse. Assim, tanto no caso da gestão do CEU Butantã quanto em sua biblioteca, o acúmulo de extensividades no âmbito do espaço, das normas de funcionamento e dos dispositivos de gestão participativa relacionam-se não apenas com a possibilidade do afastamento, como também com sua ambiguidade de sentido.

\subsection{Conjunto dos espaços}

Os fatos observados na biblioteca do CEU Butantã sugerem um processo que começa com a existência de contextos extensivos, capazes de proporcionar tomadas mútuas de distância entre subjetividades dotadas de valores pouco compatíveis. As distâncias reforçam-se com a posse de ambientes exclusivos, que originam contextos separadores menores em meio à extensividade inicial. Esses ambientes confundem-se com as subjetividades em interação, ou seja, havia um entrelaçamento entre as identidades de pessoas e lugares, e estes últimos também passaram a entrar em interação de acordo com suas próprias regras e seus próprios recursos. As interações passam a ocorrer em dois planos simultâneos, distintos e complementares: no primeiro, há uma extensividade entre as pessoas; no segundo, uma intensividade entre os ambientes, graças às separações responsáveis por sua constituição. Em outras palavras, para a interação entre funcionários, a biblioteca do CEU Butantã possuía abundância de espaço, mas para a interação entre os ambientes, o espaço era pequeno. Vale observar que a definição do tipo de contexto, em cada um dos dois planos, faz-se em função das características de cada plano e de cada tipo de agente, mas o motor dos processos é o mesmo: são as incompatibilidades de valores que presidem tanto as relações extensivas entre pessoas quanto as relações intensivas entre ambientes. 
Um desdobramento importante da intensividade disruptiva entre ambientes consiste nos efeitos da repulsão simbólica e prática exercida pelo espaço de catalogação. Ao seu redor, encontram-se áreas de aproveitamento difícil para outra atividade que não a circulação, e os ambientes vizinhos sofrem, surpreendentemente, de falta de espaço. Já vimos, por exemplo, na fala da coordenadora, que as estantes ocupavam os espaços "que sobraram". Somem-se a isso os depoimentos de dois usuários que reclamaram da falta de espaço no ambiente de leitura, chamando atenção para o barulho produzido pelo bater de cadeiras e mesas em função da movimentação de pessoas ali. A centralidade e preponderância do espaço de catalogação certamente não é o único fator a produzir essas consequências, mas com certeza fornece uma contribuição importante, sobretudo por se constituir como contexto separador.

O modo como os ambientes da biblioteca do CEU Butantã passam a interagir entre si de modo relativamente independente das interações entre as pessoas assemelha-se à forma como os territórios mais amplos do centro educacional estabelecem relações, conforme análise do capítulo anterior. Naquela discussão, observamos que as porções norte e sul do CEU expandiam-se até se tocarem e gerarem pontos de intensividade representados, por exemplo, pelos conflitos em torno da ocupação das piscinas. Mais particularmente, observamos que a pista de skate do CEU suscitava preocupações por si mesma, de modo relativamente independente da presença e das ações dos skatistas. Enfim, essas constatações deixam clara a existência de uma dinâmica envolvendo espaços de diferentes tamanhos e naturezas, e que pode ser entendida da seguinte forma: animosidades interpessoais em meio a contextos extensivos podem gerar afastamentos interpessoais recíprocos, seguidos de formações e expansões de territórios, até que esses mesmos territórios passam a estabelecer pontos de contato e, consequentemente, intensividades.

Com isso podemos indicar um possível desdobramento das análises de contexto que viemos desenvolvendo no decorrer da pesquisa. Nossas observações vinham realizando uma distinção entre as interações entre pessoas e os contextos que lhes servem de palco, mas agora os próprios contextos - representados pelos ambientes da biblioteca ou por territórios mais amplos do centro educacional - passam a interagir, desenvolvendo comportamentos que não se assemelham àqueles que podemos atribuir às pessoas. Em certo sentido, podemos dizer que os ambientes de uma biblioteca estão atravessados por agências tanto quanto os corpos humanos, e cada um deles possui seu próprio estilo de agir. As pessoas são levadas a interagir em função de suas características corporais, culturais, sociais, entre outras; os ambientes de uma biblioteca, por 
sua vez, interagem de acordo com suas características constitutivas, relativas a tamanhos, modos de acesso, distâncias e relações entre objetos, capacidades e velocidades de transformação, modos como são percebidos e praticados etc. Deixamos assim indicada a possibilidade de empregar análises de contexto não apenas para pessoas, mas para elementos não humanos, contanto que sejam capazes de interagir e que sejam dotados de alguma forma particular de agência. ${ }^{165}$

Em resumo: na extensividade da biblioteca do CEU Butantã - da mesma forma que vimos ocorrer no centro educacional em que se insere -, as separações reforçam posições e subjetividades antagônicas, que terminam por criar intensividades disruptivas entre ambientes. Por sua vez, a biblioteca do CEU Vila Rubi também parece replicar o quadro construído no capítulo anterior para a gestão do seu próprio centro educacional: aqui também podemos observar como a biblioteca constitui-se como um contexto extensivo deliberadamente procurado pelas pessoas. O risco de desaceleração inerente à extensividade é combatido com a promoção de intensividades menores que despertam o interesse das pessoas (como a disponibilização do site Facebook, conversas com autores de livros, oficinas de xadrez, espaços para prática de desenhos etc.). No interior da biblioteca - assim como no interior do centro educacional do qual faz parte a efetivação do acolhimento e a entrega de serviços é garantida por parcelas importantes de intensividade, na forma de espaços exíguos e procedimentos legais que aproximam funcionários e usuários. Isso gera uma aceleração intensa das dinâmicas interacionais, que passa a ser manejada e articulada graças à implantação de contextos separadores - estantes, mesas e delimitações de uso de espaços específicos.

Além dessas diferenças fundamentais na constituição de contextos e dinâmicas interacionais, é preciso sempre lembrar do fator decisivo representado pelos valores e intenções das pessoas. Se o CEU Butantã possui uma trajetória histórica e um corpo de funcionários marcados por clivagens que privilegiam ora o acolhimento, ora a organização e a segurança, a sua biblioteca encontra-se dividida de modo análogo entre o privilégio a livros ou o privilégio a usuários. No CEU Vila Rubi, por sua vez, observamos que o acolhimento não foi visto como incompatível com a garantia da segurança, da mesma forma que sua biblioteca preocupava-se tanto em beneficiar os usuários quanto em garantir a organização interna de seus recursos e espaços.

\footnotetext{
${ }^{165}$ Formulações semelhantes de agência são empregadas por diversas pesquisas em Antropologia, e recebem uma definição suscinta em Sax (2006, p. 473).
} 


\subsection{Reforma da biblioteca do CEU Butantã}

A proposta de reforma da biblioteca do CEU Butantã surgiu em fins de 2012, numa ocasião em que a coordenadora me explicava a forma como os espaços da biblioteca foram evoluindo. Ela considerou ter feito "o possível" neste assunto, e estava nitidamente insatisfeita com o resultado. Observamos como a centralidade da ilha de catalogação comprimia o espaço das mesas de leitura e das estantes, prejudicando ainda as exposições periódicas, que tinham de ocupar espaços descontínuos representados pelo foyer e por uma área lateral à ilha de catalogação conforme indicado na figura 43 . O espaço infantil ao fundo da biblioteca também encontrava-se comprimido e era difícil de ser ocupado, o ambiente para encontros e eventos configurado por picadeiros estava nos fundos da biblioteca e era pouco utilizado, e de modo geral havia um excesso de circulações que reduzia a área útil destinada aos ambientes.

No início do desenvolvimento do projeto de reforma, refleti que as transformações de espaço poderiam ser realizadas com certa facilidade, envolvendo basicamente realocações de móveis. Por outro lado, como visto anteriormente, a ilha de catalogação e a sala de coordenação vinculavam-se às subjetividades das bibliotecárias, e a política de suas interações cotidianas seria significativamente alterada. Além disso, mudanças de espaço poderiam favorecer ou dificultar o atendimento aos usuários e os cuidados com a preservação do acervo, e uma dessas preocupações poderia prevalecer sobre a outra. A expectativa com as mudanças aumentou quando realizei algumas discussões preliminares de projeto com a coordenadora da biblioteca, no início de 2013: as bibliotecárias subordinadas levaram o assunto ao conhecimento da então gestora do CEU, Eliane dos Santos Luscri, e surgiram impasses para a produção de entendimentos coletivos. Os ânimos melhoraram quando dei prosseguimento aos estudos, buscando associar a etnografia às decisões de projeto por meio de entrevistas com todas as funcionárias e com três usuários que na época frequentavam a biblioteca com assiduidade. As entrevistas foram realizadas em março de 2013 e trouxeram informações importantes para certas decisões de projeto, como ficará claro mais adiante. 
Em maio o projeto passou por revisões, em virtude das mudanças trazidas pelo início do mandato de Fernando Haddad. A decisão de implantar polos da Universidade Aberta do Brasil ${ }^{166}$ trouxe reformas repentinas a vários centros educacionais da cidade. A velocidade das decisões políticas trouxe descontentamentos a usuários e funcionários locais, que não foram consultados ou avisados sobre as mudanças. Em maio de 2013, a biblioteca do CEU Butantã perdeu o espaço dos fundos, que havia sido objeto de disputas por vários anos, para uma sala de teleconferências da futura universidade, sofrendo uma redução de cerca de um quinto de sua área. No entanto, boa parte desse espaço já estava sendo ocupado pelo clube de xadrez anteriormente mencionado, e as adequações que realizei no projeto de reforma foram capazes de minimizar as perdas. Funcionários da Diretoria Regional de Ensino do Butantã responsáveis pelas mudanças comprometeram-se com compensações, aderindo à construção de uma sala para as bibliotecárias e de uma reforma do banheiro e da copa, mas tentativas de retomar o assunto não suscitaram mais retornos.

Outra mudança trazida pelo mandato de Fernando Haddad foi a chegada de novos gestores e diretores regionais, interessados em participar de forma mais ativa nas discussões sobre a reforma da biblioteca. Eles atuaram como articuladores importantes dos interesses das bibliotecárias, ao longo de três reuniões ocorridas entre junho e julho de 2013. As últimas decisões de mudança foram tomadas coletivamente nessas reuniões e produziram a oitava e última versão do projeto.

A reforma, no entanto, só ocorreu em meados de dezembro de 2013, um ano depois do início das discussões, quando pude estar presente por três dias seguidos no CEU. Um fator decisivo para a implementação das mudanças foi a minha presença ativa e em tempo integral, já que a liberdade de ação e interação predominante nas relações entre funcionários deste centro educacional favorecia evasivas de todo tipo. Assim, a morosidade das discussões de projeto acima mencionadas e as dificuldades de concretizar as propostas são uma boa amostra de como operam as acomodações e afastamentos trazidos pela maximização de extensividades no CEU Butantã. As bibliotecárias subordinadas tiveram um envolvimento mínimo com a reforma, já que uma delas ausentou-se alegando problemas de saúde que teriam ocorrido em seu âmbito familiar, e a outra justificou sua presença com o declarado propósito de garantir a segurança de seus

\footnotetext{
${ }^{166}$ Trata-se de uma universidade que é fruto de parceria entre as esferas federal, estadual e municipal, e entre diversas universidades, para oferecer cursos de graduação e pós-graduação a distância, em regime semipresencial.
} 
pertences pessoais e a organização dos livros nas estantes, preocupando-se também com a visibilidade dos espaços da biblioteca e com as futuras dificuldades que poderiam ocorrer para a vigilância das atividades dos usuários.

As mudanças de estantes, armários, livros e equipamentos foram realizadas por um grupo formado por mim, pela coordenadora e por duas funcionárias ligadas à biblioteca - uma assistente técnica de ensino e uma faxineira. Mas o trabalho pesado contou com a colaboração dos funcionários da empresa terceirizada Tonani, responsável pela limpeza de todo o CEU. Equipes de dois a quatro desses funcionários prestaram uma ajuda decisiva no processo, mas para isso foi preciso fazer frente à facilidade que tinham em se afastar do trabalho, graças às extensividades representadas pelos amplos espaços do CEU e pela inefetividade na observância de hierarquias de trabalho. Assim, os funcionários da Tonani não compareceram à primeira manhã da reforma, apesar de sua participação ter sido previamente agendada. Ao entrar em contato via telefone com a chefe da equipe da Tonani, a coordenadora da biblioteca não obteve retorno sobre a efetivação do auxílio; depois de insistir com novas ligações, recebeu a informação de que os funcionários estavam ocupados em tarefas com prazo indefinido de conclusão. A presença dos funcionários só foi garantida depois que tomei a iniciativa de sair correndo atrás deles pelo CEU, procurando sensibilizá-los com um tom firme, enérgico e animado que tive que sustentar no decorrer dos trabalhos.

Outros detalhes da implementação do projeto aparecerão ao longo da apresentação dos novos espaços e das consequências trazidas para o cotidiano da biblioteca. Para acompanhar esta discussão apresentamos a perspectiva do resultado final da reforma. 


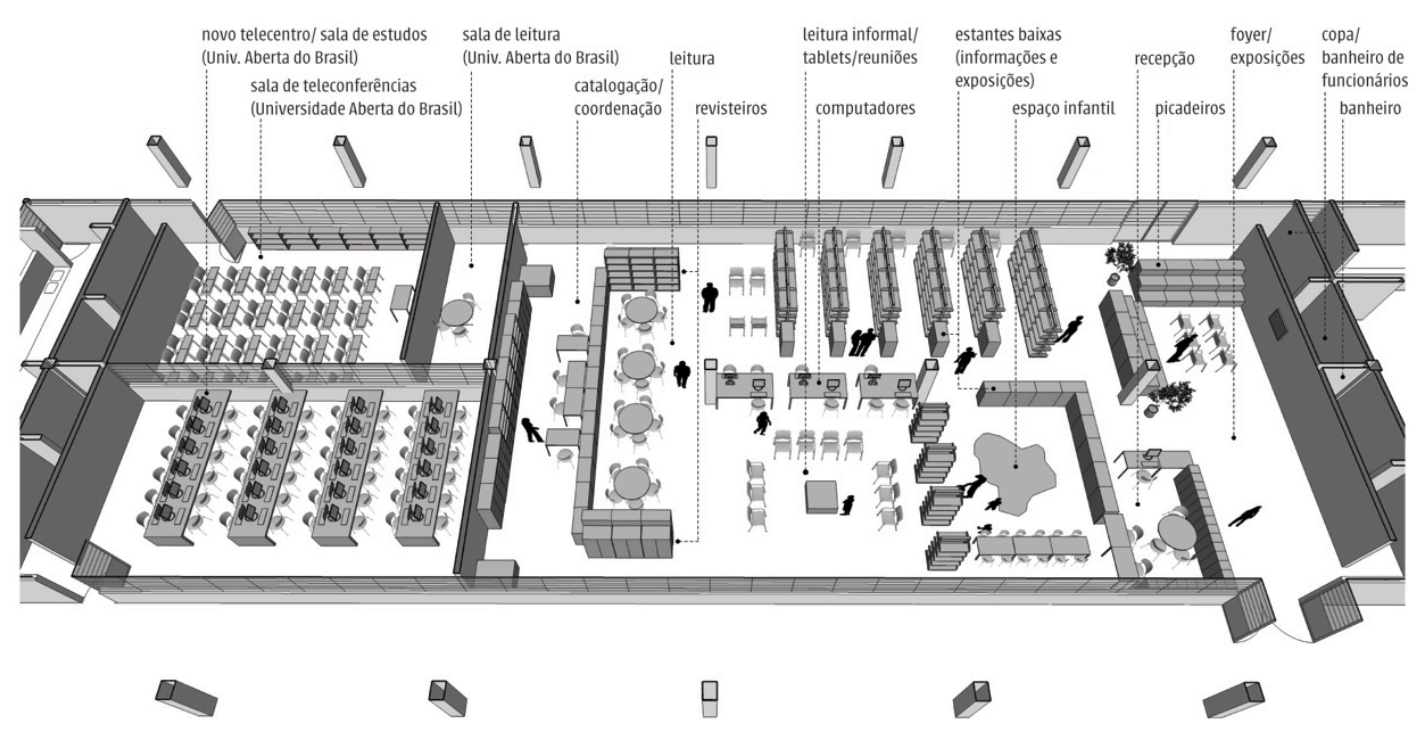

Figura 56 - Perspectiva da reforma da biblioteca do CEU Butantã.

A solução de projeto procurou compactar áreas administrativas, de circulação e de guarda de acervo para configurar cinco lugares destinados aos usuários, que aumentam suas possibilidades de escolha e configuram contextos extensivos. A amplitude desses espaços e a possibilidade de apreendê-los todos visualmente num só golpe de vista facilitam a sua apropriação e aumentam a extensividade. Isso fica claro quando imaginamos as dificuldades que poderiam surgir com uma solução que empregasse obstruções maiores entre esses lugares. No entanto, o projeto não trabalhou apenas com a garantia da liberdade de ação e interação. A extensividade foi limitada com o emprego comedido de separações, de modo a produzir regulações de acesso apenas onde elas se fazem imprescindíveis: no gargalo da recepção e na conformação do espaço de catalogação e coordenação. Concentrando-se no início e no fim do espaço da biblioteca, as separações deixaram de ocupar os ambientes de estar do meio, destinados aos usuários. As separações foram configuradas unicamente com o emprego de armários baixos, que restringem deslocamentos corporais mas permitem a troca de olhares e o estabelecimento de algumas conversas. ${ }^{167}$ Em certos casos, isso amplia interações voluntárias, já que usuários podem trocar palavras com funcionários por cima dos armários. Por outro lado, os armários baixos

\footnotetext{
${ }^{167} \mathrm{O}$ projeto de leiaute original - como mostra a figura 44 - segue o partido arquitetônico geral do CEU, garantindo uma extensividade total no interior da biblioteca. Os armários baixos foram encostados nas paredes perimetrais e a recepção não configura um gargalo para controle do acesso ao interior da biblioteca. No entanto, na prática, em todos os CEUs projetados durante a gestão Marta Suplicy que visitei, os armários baixos foram dispostos no interior da planta para separar ambientes e controlar fluxos, além de servirem como locais de armazenagem.
} 
configuram contextos intensivos porque dificultam aos usuários fugir do campo de visão das bibliotecárias. ${ }^{168}$ A permeabilidade visual necessária ao monitoramento dos usuários foi a principal demanda das bibliotecárias subordinadas, o que mostra como a preocupação com a preservação do acervo - anteriormente observada como marcador de diferenças entre concepções de serviço público - reaparece durante o desenvolvimento do projeto de reforma.

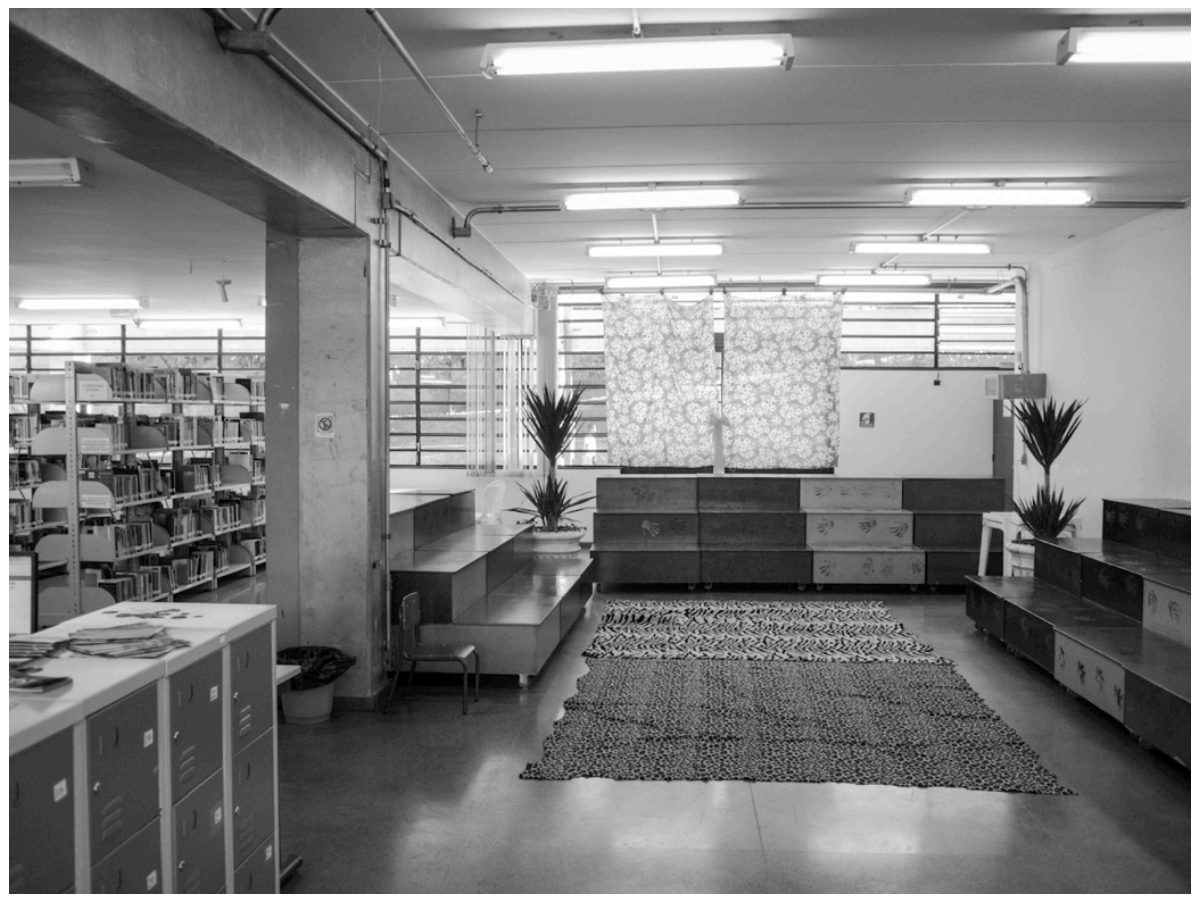

Figura 57 - Foyer da biblioteca do CEU Butantã, com picadeiros, após a reforma. Atrás dos picadeiros encontra-se o corredor de acesso ao banheiro e à copa dos funcionários.

O primeiro desses lugares é o foyer de acesso, que passou a ocupar toda a largura da biblioteca. Uma das intenções iniciais desta proposta era permitir que a biblioteca pudesse ser adentrada pelo segundo acesso (em frente ao principal). Porém, desde as primeiras conversas ficou claro que isso não seria possível, já que o espaço dos fundos do CEU é atualmente

\footnotetext{
${ }^{168}$ A discussão mostra que armários baixos podem configurar contextos separadores entre corpos e, ao mesmo tempo, extensividades que permitem trocas de olhares e diálogos; quando as interações envolvem vigilância de usuários, os armários baixos também representam intensividades. A concomitância desses contextos indica que o espaço nem sempre deve ser substantivado ou reificado como uma dimensão única a regular todas as espécies de interação. O espaço pode ser decomposto em diversas frentes, cada uma delas sendo relevante em um caso e não em outro. Decomposições subsequentes do âmbito espacial poderiam gerar contextos diferentes não apenas entre corpos, olhares e vozes, mas também, por exemplo, entre odores e barulhos. Na pesquisa, as relações "inter-âmbitos" (por exemplo, entre vínculos empregatícios intensivos e espaços físicos extensivos) mostraram-se mais importantes do que essas relações "intra-âmbitos". Ao mencioná-las, fazemos referência a outro conjunto de complicações subjacentes aos conceitos aqui propostos.
} 
reservado ao recreio de alunos da EMEF, e na opinião da coordenadora da biblioteca seria muito difícil impedir que alunos escapassem da escola cruzando o foyer. De qualquer forma, a proposta de um foyer ampliado continuou relevante, por permitir a realização de diversas atividades sem que haja a necessidade de seus participantes passarem pelo contexto separador representado pelo controle de acesso da recepção. Picadeiros móveis de madeira, anteriormente subutilizados num ambiente nos fundos da biblioteca, foram trazidos ao foyer e passaram a ser ocupados regularmente por turmas de alunos da EMEI e do CEI em atividades de contação de histórias. Os picadeiros também passaram a sediar alguns dos saraus mensais organizados pela coordenadora, disputando atenções com outros lugares da biblioteca. Exposições periódicas instaladas no foyer também tornaram-se visitáveis sem a necessidade de passar pelo gargalo da recepção, e a retirada de conduítes e móveis da parede entre foyer e banheiros permitiu que ela seja facilmente utilizada para pendurar painéis e outros suportes expositivos.

A parte de trás dos picadeiros forma um corredor de acesso a um banheiro que passou a ser utilizado também como copa, com acesso exclusivo dos funcionários da biblioteca. Durante uma das discussões de projeto com bibliotecários e gestores, a capacidade de estes móveis configurarem separações foi questionada por uma das bibliotecárias subordinadas, que considerou que jovens poderiam burlar o controle de acesso da recepção pulando a esquina dos picadeiros. Nesse momento surgiu a ideia de dificultar a prática colocando um vaso de plantas no local, conforme indicado na figura $57 .{ }^{169}$

\footnotetext{
${ }^{169}$ Buscando amenizar as diferenças de posicionamento, um dos gestores ironizou observando que, se dependesse da bibliotecária subordinada, a planta escolhida seria um cacto. Esse comentário representou um momento de descontração que não veio a se repetir posteriormente.
} 


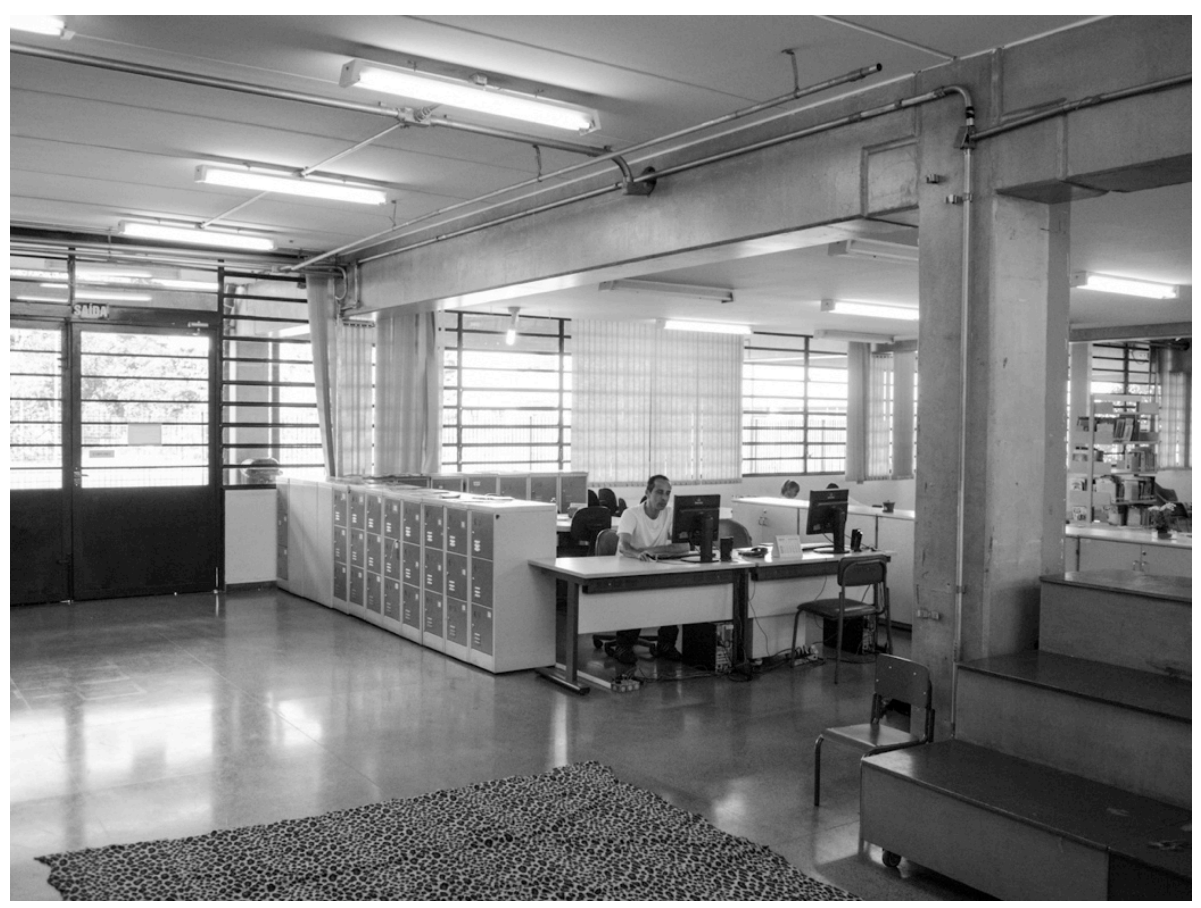

Figura 58 - Vista da ilha de recepção e porta de entrada da biblioteca do CEU Butantã, após a reforma.

A recepção foi posicionada ao lado do foyer de entrada para regular o acesso ao corredor central de circulação da biblioteca. Essa posição atende às preocupações das bibliotecárias em contar com um bom campo de visão desde seus postos de trabalho ao interior da biblioteca, garantindo uma ampliação da intensividade no que se refere ao monitoramento das atividades dos usuários. As mesas de recepção não foram alinhadas com o corredor central de circulação porque a proximidade com o pilar atrapalharia a interação com o público. Elas foram recuadas mais para perto da porta de entrada, e o recesso resultante reforçou a intensividade necessária ao controle de entrada e saída de pessoas e itens de acervo. As mesas foram posicionadas de frente para esse recesso, mas em compensação ficaram de costas para a porta de entrada da biblioteca. Depois de realizada a reforma, as bibliotecárias subordinadas revelaram-se incomodadas com a necessidade de virarem-se para averiguar a chegada de frequentadores. É provável que o desconforto também estivesse relacionado à permeabilidade visual entre interior e exterior da biblioteca, o que permitia que suas atividades pudessem ser observadas pelas pessoas que passavam pelo corredor externo de circulação do CEU. Neste caso a busca por uma posição que lhes permitisse observar o interior da biblioteca fez com que elas também se encontrassem expostas aos olhares dos frequentadores, ou seja, a intensividade valia nos dois sentidos. 


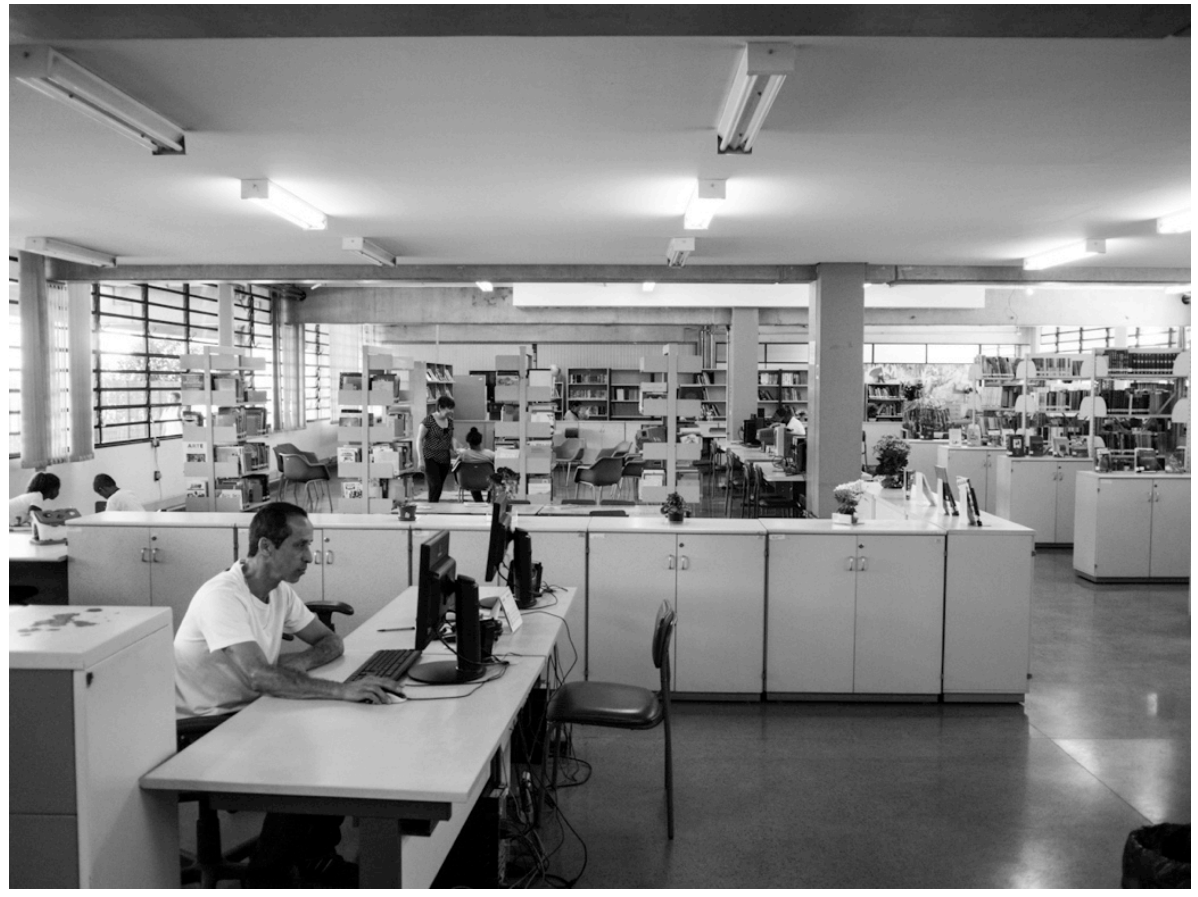

Figura 59 - Campo de visão dos bibliotecários situados na mesa da recepção da biblioteca do CEU Butantã, após a reforma.

Esta outra imagem mostra o campo de visão privilegiado das mesas de recepção ao interior da biblioteca. A preocupação com esse aspecto era grande, e durante as discussões de projeto uma das bibliotecárias subordinadas reparou que algumas mesas de leitura não seriam visíveis a partir daí. A solução proposta foi mantida por falta de alternativas, e graças à intervenção dos gestores presentes, que observaram que não existe "risco zero". 


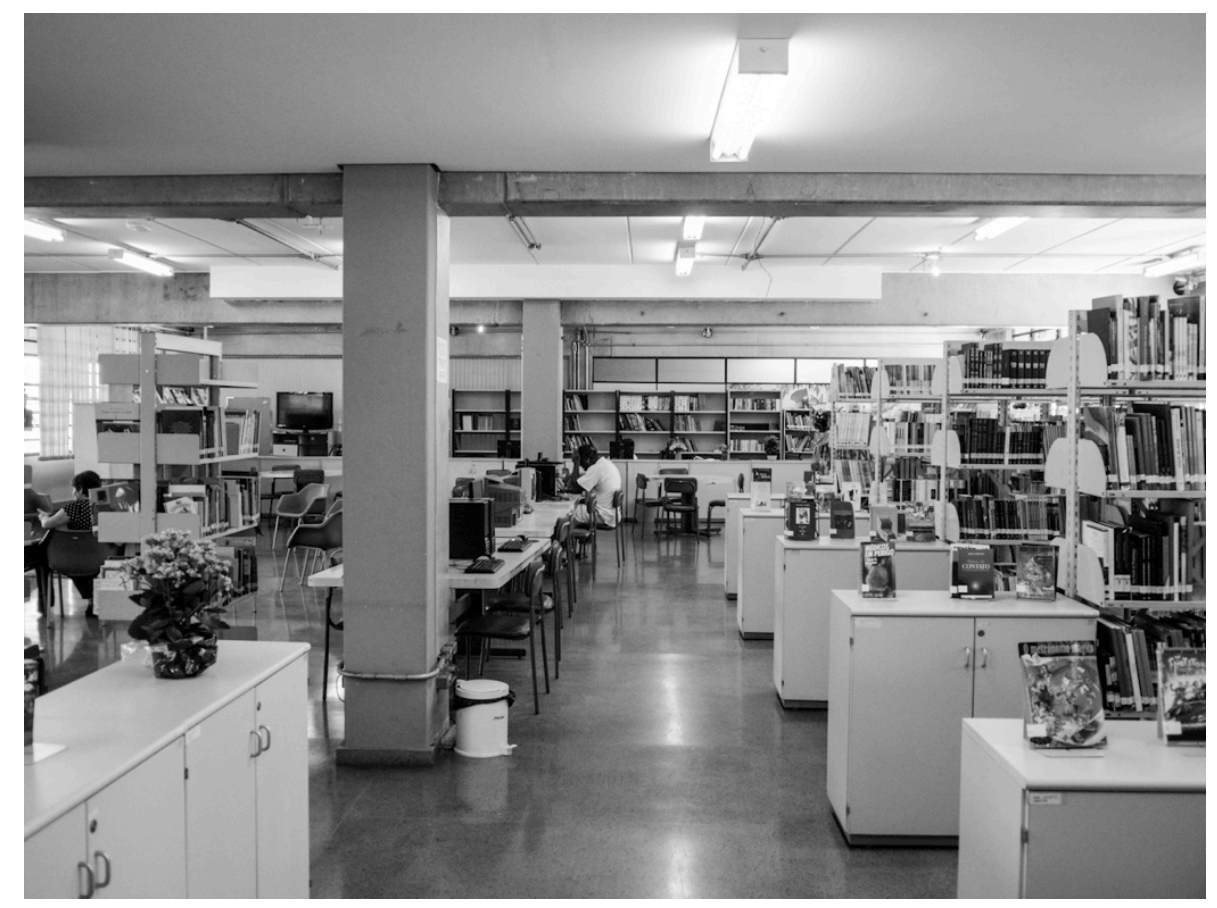

Figura 60 - Novo corredor de circulação central da biblioteca do CEU Butantã, após a reforma.

Depois de passar pela recepção, os usuários são levados a atravessar um corredor central de circulação, pensado como metáfora de uma rua, ao longo da qual diferentes frequentadores são levados a se encontrar. A configuração de circulações como espaços de encontro é um recurso bastante empregado no campo da arquitetura, e nos termos desta pesquisa pode ser considerado como criador de intensividades favorecedoras de intercâmbios, não relacionadas à preocupação com a vigilância dos usuários por parte das bibliotecárias. Intensividades deste tipo podem adquirir grande relevância num CEU que, como vimos anteriormente, padece com as desacelerações produzidas pelo efeito conjunto dos outros dois tipos de contexto. Espaços que induzem o convívio poderiam ser empregados para acelerar as dinâmicas interacionais e combater as tendências de afastamentos e acomodações, aproximando o CEU Butantã da configuração de contextos que observamos no CEU Vila Rubi.

No entanto, o poder de influência do espaço sobre as dinâmicas interacionais é obviamente limitado, e precisa ser tratado como um dos fatores de uma equação que envolve um rearranjo mais amplo de contextos, entre outros aspectos. Com uma quantidade baixa de visitantes, a intensividade do corredor de circulação não chega a se configurar. As diferenças de valores e concepções de serviço público, dividindo funcionários que priorizam "livros" e "usuários", continuam se constituindo como principal entrave para a atração de público e efetivação do 
acolhimento. Estas divergências terminam sendo reforçadas pela predominância de extensividades de âmbito espacial e profissional, possibilitando afastamentos interpessoais difíceis de serem revertidos. Se intensividades como a do corredor de circulação contassem com o reforço de outras, estabelecidas no âmbito das relações empregatícias de um modo geral, elas poderiam contribuir para combater esses afastamentos. Obviamente uma aceleração das dinâmicas interacionais não seria garantia de promoção do acolhimento, mas no caso desta biblioteca ela poderia associar-se com um reforço de hierarquias de poder e da autoridade da coordenadora, de modo que a preocupação com os "usuários" prevalecesse sobre a preocupação com a preservação dos "livros". Outra proposta de produção de intensividades de âmbito espacial entre funcionárias será vista ao tratarmos do ambiente de coordenação e catalogação.

A solução final do projeto para o corredor de circulação havia previsto que as estantes de livros terminassem em revisteiros altos. Isso causou desconforto, durante a reforma, a uma das bibliotecárias subordinadas, já que eles comprometeriam a visibilidade já parcial dos corredores entre as estantes. A solução foi colocar os revisteiros em ambas as extremidades do ambiente de leitura - representados na figura 56 -, e substituir sua presença no corredor por armários baixos. O resultado, indicado na fotografia acima, trouxe a possibilidade de apresentar sugestões de leitura aos visitantes que passam pelo corredor.

Durante a discussão que levou a esta mudança, uma das bibliotecárias subordinadas procurou observar que a preocupação com a preservação do acervo estava diretamente relacionada ao risco de ela própria ser responsabilizada por quaisquer prejuízos que viessem a ser causados na biblioteca. Essa observação assemelha-se àquela manifestada pela gestora Eliane dos Santos Luscri no capítulo anterior, segundo quem a sugestão de implantar carteirinhas também era motivada pelo receio de ser pessoalmente responsabilizada por ocorrências que acontecessem no interior do CEU. Novamente temos um exemplo de que a preocupação com a segurança está mesclada com a preocupação com a própria segurança. ${ }^{170}$

\footnotetext{
${ }^{170}$ Seria interessante investigar se a relutância em assumir riscos não é mais frequente entre funcionários públicos efetivos, já que sua escolha profissional deu preferência a vínculos empregatícios estáveis e de longo prazo, que envolvem parcelas menores de incerteza do que as que caracterizam as carreiras de funcionários nomeados ou de trabalhadores da iniciativa privada de um modo geral. Queremos sugerir a existência de uma contradição entre a previsibilidade da carreira pública e a imprevisibilidade característica do livre acesso que geralmente acompanha a coisa pública. Se a carreira pública atrai pessoas altamente sensíveis à segurança e à estabilidade, muitas delas precisam se defrontar com uma parcela significativa de risco em seu cotidiano de trabalho, sobretudo quando ocorre uma maximização de extensividades como a que vimos nos primeiros anos do CEU Butantã. Parte da diferença de posições entre as bibliotecárias subordinadas e a coordenadora passa pelo fato de as primeiras serem efetivas e a segunda, nomeada. A coordenadora encontra-se frequentemente às voltas com a incerteza em sua trajetória
} 
O corredor de circulação dá acesso a quatro espaços de leitura e de estar destinados aos usuários. Seguindo sugestões de um usuário, o espaço infantil foi localizado ao lado da recepção para evitar barulhos e correrias na parte posterior da biblioteca. Este espaço, no entanto, passou a receber ainda menos visitas do que recebia antes da reforma, já que a maior parte das turmas de alunos do CEI e da EMEI passou a se dirigir aos picadeiros do foyer.

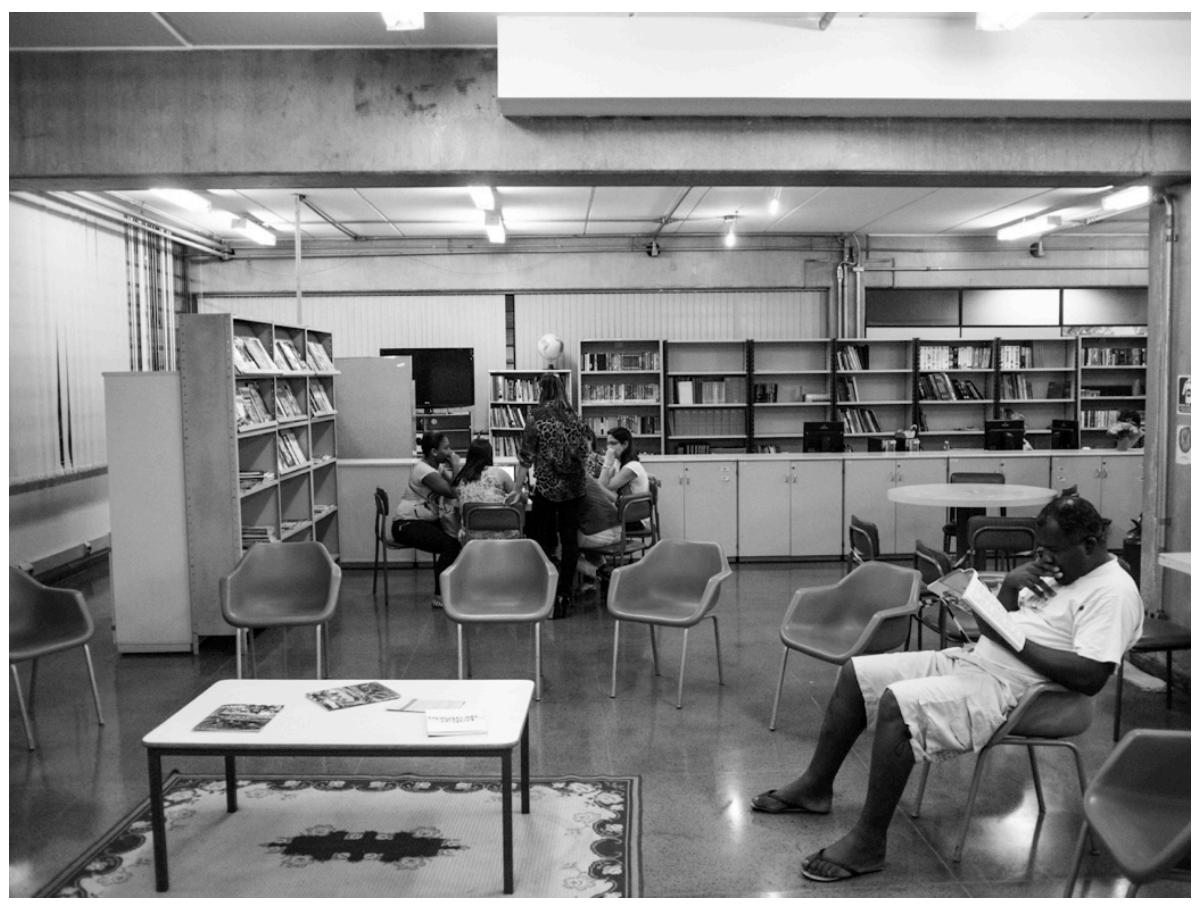

Figura 61 - Ambiente para leitura informal do CEU Butantã após a reforma, em primeiro plano. Logo após podem ser avistadas as mesas redondas, os revisteiros (à esquerda da imagem) e o corredor de acesso ao ambiente de catalogação e coordenação (na extrema esquerda).

Ao lado do espaço infantil, foi previsto um ambiente com cadeiras de braço e mesa de centro, adequado para leituras mais descontraídas e atividades que envolvem reunião de pessoas, como os saraus organizados mensalmente pela coordenadora da biblioteca. A intenção era a de que o espaço também recebesse pufes e tablets num futuro próximo. Este lugar também tem sido menos utilizado do que as previsões, porque alguns dos saraus têm acontecido nos picadeiros do foyer, e a possibilidade de escolher o local a ocupar é um fator ampliador da extensividade dos usuários.

profissional, de uma forma muito diferente de suas subordinadas. Estas encontram-se protegidas por protocolos rígidos que dificultam ou mesmo impedem a ativação de hierarquias de trabalho e mesmo a demissão por justa causa. 


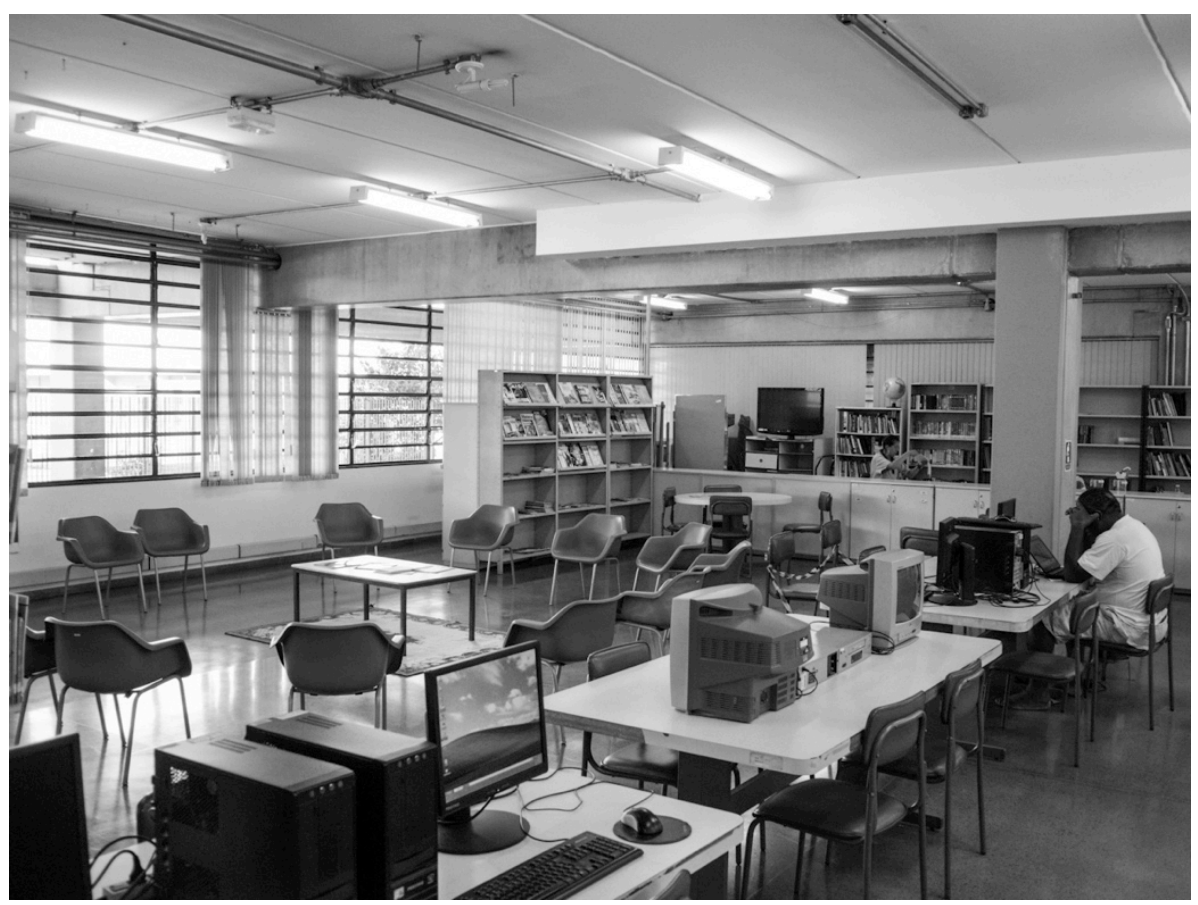

Figura 62 - Vista do corredor central da biblioteca do CEU Butantã, com nova disposição dos computadores e televisores.

Outro núcleo de atividades disponível aos usuários consiste nas mesas com televisores e computadores que foram dispostas na lateral do corredor de circulação. Vimos que os computadores eram pouco utilizados antes da reforma, e o seu posicionamento numa área central da biblioteca poderia atuar como incentivo à procura. No entanto, pouco depois da reforma os cabos de energia que desciam do teto e alimentavam duas das três mesas foram retirados não por decisão da coordenadora, mas porque um novo membro da equipe de bibliotecários os considerou um incômodo, de modo que atualmente apenas um computador está disponível à utilização. Esta é mais uma consequência do já mencionado enfraquecimento de hierarquias, associado à indisposição para a efetivação de acordos mútuos entre funcionários desta biblioteca. 


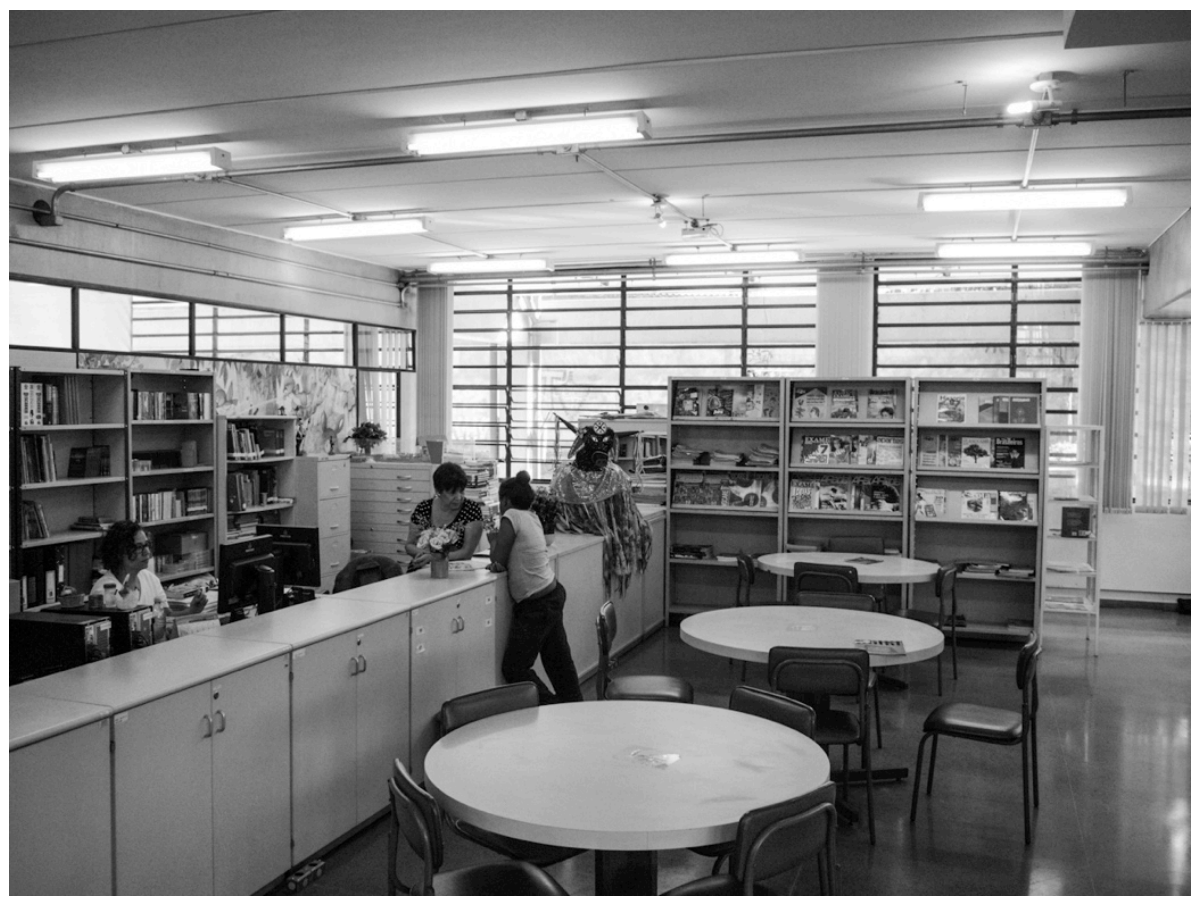

Figura 63 - Conversa através dos armários baixos que separam o novo ambiente de coordenação e catalogação do resto da biblioteca do CEU Butantã. Ao fundo podem ser vistos os revisteiros.

O principal espaço de leitura da biblioteca configura-se com o conjunto de mesas redondas localizadas ao final do corredor de circulação. A utilização das mesas mantém-se escassa, mas aumentou um pouco graças à instalação de pontos de eletricidade ao longo da série de armários baixos, para permitir a utilização de laptops. Destaca-se a maior frequência de grupos de alunos da ETEC, que utilizam o espaço em fins de tarde para realizar trabalhos coletivos antes do início de suas aulas.

As mesas de leitura avizinham-se do ambiente de catalogação e coordenação, nos fundos da biblioteca. Depois da recepção, este é o segundo espaço de uso exclusivo das bibliotecárias, e precisou contar com separações formadas por armários baixos na parte frontal e revisteiros e armários altos nas laterais. As obstruções mais altas foram posicionadas nas extremidades para não obstruir a permeabilidade visual que predomina em toda a biblioteca, e para configurar e esconder os corredores laterais de acesso restrito.

Neste local, os armários baixos continuam produzindo combinações de contexto anteriormente mencionadas, com certas particularidades. Impedindo o acesso físico, eles representam separações, mas garantem a possibilidade de efetivação de conversas entre bibliotecárias e usuários - neste sentido, configuram extensividades. Os armários baixos também 
procuraram atender às preocupações com o monitoramento - neste sentido, configuram intensividades que reduzem bastante as chances de os usuários evitarem olhares das bibliotecárias. Vimos que, de certo modo, a intensividade da recepção é recíproca e também expõe as bibliotecárias aos olhares dos usuários que entram na biblioteca ou passam pelo corredor de circulação exterior do CEU. No caso do espaço de catalogação e coordenação, a intensividade é bem mais forte em um dos dois sentidos, já que as atividades das bibliotecárias estão mais resguardadas. Mesmo assim, a série de estantes alinhada à parede dos fundos da biblioteca tornou visível uma grande quantidade de itens que até então estavam ocultos em estantes e armários, à espera de serem catalogados e disponibilizados ao público. A exposição dos itens parece ter funcionado como um contexto intensivo, já que despertou o interesse de alguns usuários e induziu à finalização do trabalho de catalogação, que, nesta biblioteca, era atribuição exclusiva das bibliotecárias subordinadas e esteve suspenso por certo tempo.

Outro aspecto a destacar é a localização das funções de coordenação e catalogação em um ambiente compartilhado. Vimos que anteriormente essas atividades davam-se em lugares distintos, que passaram a associar-se às subjetividades das bibliotecárias responsáveis por cada uma delas: a ilha de catalogação passou a representar as bibliotecárias subordinadas, e a sala de coordenação associou-se à coordenadora. No início das discussões sobre a reforma, propus a união das duas atividades com base no projeto original dos CEUs - representado na figura 44. Acreditava que a medida poderia incentivar acordos e diminuir animosidades, que representam o principal impedimento na efetivação do acolhimento na biblioteca. A coordenadora, por sua vez, considerava importante dispor de uma sala resguardada que lhe garantisse privacidade para guardar materiais e estabelecer conversas necessárias ao desenvolvimento de atividades que eram de sua exclusiva atribuição. As bibliotecárias subordinadas também consideravam a importância de um local que impedisse o público de interromper os processos técnicos de catalogação. Sobrepondo-se a essas necessidades estava a percepção geral de que o domínio sobre espaços particulares reforçava posições na política das interações cotidianas, e as alegações de um lado eram encaradas com reservas pelo outro. O consenso em favor do ambiente comum surgiu no final do processo de discussão e pareceu resultar menos da intenção de construir reciprocidades e mais da necessidade de evitar fortalecimentos da posição alheia.

A inexistência de separações entre a coordenação e a catalogação produziu uma intensividade que não veio acompanhada de redução de animosidades. Em certo sentido, houve 
um acirramento das dinâmicas interacionais. A proximidade com funcionários e usuários tornouse um ponto sensível para a coordenadora, incumbida de um trabalho de planejamento que não envolve o trato direto e constante com outros frequentadores. Por sua vez, a inexistência de um espaço reservado para as bibliotecárias subordinadas parece ter-lhes trazido menos incômodos, já que continuavam pouco sujeitas ao exercício das assimetrias de poder. Neste sentido, as mudanças de espaço enfraqueceram a posição favorável aos "usuários" e ao acolhimento, equiparando-a com aquela mais voltada à preservação dos "livros". Por outro lado, a compactação de lugares de trabalho nos fundos da biblioteca retirou o peso do âmbito espacial no embate entre essas duas posições, entregando a maior parte do espaço ao usufruto dos usuários.

De qualquer forma, sempre é bom lembrar que mudanças de contexto são importantes mas não decisivas para o sucesso do acolhimento. O favorecimento dos usuários e o estabelecimento de relações de reciprocidade com eles depende em grande parte das intenções sustentadas pelos funcionários, e esta biblioteca encontra-se cindida por posições incompatíveis, como vimos ao longo deste capítulo. Se o aumento de intensividades e a diminuição de separações trazidos com a reforma foram importantes para combater os afastamentos e desacelerações que caracterizam o cotidiano da biblioteca, este fator está longe de ser o único relevante. Suas consequências para o acolhimento teriam sido amplificadas se essas medidas fossem combinadas com o reforço de posição da coordenadora. Mas o CEU Butantã ainda parece marcado pelo predomínio da "filosofia de conversa" e pela valorização exclusiva da extensividade e dos acordos voluntários entre funcionários - acordos esses que não chegam a ocorrer. 


\section{CONSIDERAÇÕES FINAIS}

Nesta pesquisa, entendemos o acolhimento como uma das principais preocupações dos servidores públicos que concebem e administram os CEUs de São Paulo. Trata-se da intenção de (1) beneficiar os moradores das áreas menos favorecidas em que os CEUs se encontram, e (2) estabelecer com eles relações de diálogo e mútuo entendimento. Para que isso se efetive, um desafio importante está na forma como acontecem as interações cotidianas.

Procuramos mostrar ao longo da pesquisa que a forma como se dão as interações depende de diversos fatores, alguns deles imprevisíveis, incluindo-se aí o próprio livre-arbítrio. Mas isso não quer dizer que as dinâmicas interacionais não possam ser influenciadas numa direção ou em outra. Chamamos de contextos os aspectos da realidade dotados deste poder de influência, e os classificamos em três tipos: contextos extensivos favorecem interações voluntárias e trazem liberdades, incertezas e possibilidades de desaceleração das dinâmicas interacionais; contextos intensivos induzem as pessoas a interagir e se destacam por sua capacidade de acelerar as dinâmicas interacionais; contextos separadores, por sua vez, produzem interrupções e intermitências nas interações, aumentando sua previsibilidade e reforçando hierarquias e identidades, entre outros fatores.

No CEU Vila Rubi e em sua biblioteca, os três tipos de contexto foram combinados para garantir uma promoção particularmente bem-sucedida do acolhimento. Em primeiro lugar vimos como se dá aí uma predominância de contextos extensivos em função da frequência voluntária a diversas atividades - desde festas, cursos de teatro e aulas de costura promovidos pela gestão até oficinas de leitura e xadrez realizadas pela biblioteca, entre inúmeros outros eventos. A livre escolha de interações e participações combina-se com parcelas menores dos outros dois tipos de contexto. Contextos intensivos estão presentes sobretudo na forma de espaços reduzidos e normas de averiguação que levam as pessoas a se encontrarem e a negociarem os modos de utilização de recursos e espaços. Contextos separadores, por sua vez, aparecem representados por portões, grades, carteirinhas, listas de inscrição e outros dispositivos espaciais e legais que regulam acessos e usos, segmentam direitos e responsabilidades, e reforçam hierarquias de poder, autonomias e identidades.

Combinados desta forma, os três tipos de contexto associam suas consequências favoráveis 
à promoção do acolhimento e combatem os efeitos desfavoráveis de um e outro: as separações diminuem e articulam incertezas inerentes aos outros dois contextos; as intensividades induzem relações e evitam a desaceleração das dinâmicas interacionais; e tanto intensividades quanto separações asseguram uma certa autoridade dos funcionários sobre os usuários, sem que as extensividades e o clima de livre escolha deixem de predominar.

O CEU Butantã, por sua vez, parece exemplificar um quadro mais frequente nos CEUs da cidade, onde há maiores dificuldades para a efetivação do acolhimento. Neste caso, a pesquisa apontou para uma tensão entre dois grupos antagônicos de servidores públicos. Num primeiro momento, a promoção do acolhimento foi exclusivamente associada a contextos extensivos, representados por espaços abertos e livremente acessíveis, e por um estilo de gestão fundamentado quase exclusivamente em adesões voluntárias de funcionários e usuários. Sem os outros dois tipos de contexto, a liberdade ampliada trouxe também uma parcela considerável de incerteza e de consequências indesejáveis para o cotidiano do centro educacional.

Servidores favoráveis às extensividades entenderam a incerteza como parte inevitável de um processo de aprendizado e de construção de diálogo com os usuários. No entanto, outros funcionários - inclusive os que passaram a gerir o CEU entre 2005 e 2012 - perceberam a incerteza como "desorganização" e "falta de segurança". Eles procuraram aumentar a previsibilidade das dinâmicas interacionais, multiplicando contextos separadores com a redução do número de atividades oferecidas e o enrijecimento de normas para utilização de espaços e recursos. Como vimos, as mudanças não eram apenas uma reação às extensividades anteriormente implementadas, mas se orientavam por seus próprios valores, mostrando-se pouco interessadas na promoção do acolhimento.

O antagonismo de posições reaparece na biblioteca do CEU Butantã, dividindo a equipe de bibliotecárias entre aquelas interessadas em favorecer os "usuários" com certas flexibilizações de normas, de um lado, e aquelas mais interessadas em preservar os "livros" e eliminar os riscos de serem responsabilizadas por prejuízos, de outro. A forma como estas últimas preocupavam-se em vigiar, aplicar suspensões por atraso e tomar outras medidas de segurança contribuía para afastar os usuários da biblioteca.

No CEU Butantã e em sua biblioteca, as separações foram empregadas em grande quantidade, e de uma forma muito diferente da que observamos no CEU Vila Rubi: não para garantir um mínimo de previsibilidade em meio ao predomínio de liberdades, mas para reduzir 
significativamente estas liberdades. Nesse sentido, as extensividades e separações se opuseram, e as interações não voluntárias das segundas combateram as voluntárias das primeiras. Concomitantemente, no entanto, aparecem combinadas as características comuns aos dois contextos, já que ambos (contextos extensivos e separadores) são capazes de produzir desacelerações nas dinâmicas interacionais: de um lado os contextos separadores forçaram afastamentos de usuários e funcionários; de outro as pessoas preferiram se afastar mesmo quando as extensividades originais, em parte ainda presentes, garantiam-lhes certo poder de optar pelas interações. Tal combinação de afastamentos voluntários e não voluntários adquiriu grande importância também porque no CEU Butantã quase não se observam contextos intensivos, que em nossa análise são os únicos capazes de se contrapor aos afastamentos, induzindo as pessoas a interagir.

Esta breve retomada indica que uma parte das dificuldades de promoção do acolhimento no CEU Butantã deve-se à presença de dicotomias que organizam grupos antagônicos de servidores, valores, contextos e períodos de tempo. No entanto, um estilo de pensar e agir por dicotomias aparece não apenas entre os servidores que administram o CEU Butantã, mas em parte dos discursos de esquerda daqueles que conceberam os primeiros CEUs, durante a gestão Marta Suplicy. Com base nas constatações da pesquisa, talvez seja o momento de lançar questões para uma possível reconsideração desses discursos. Nosso propósito de forma alguma é realizar uma avaliação geral deles, mas propor certos realinhamentos que coloquem em xeque o dispositivo dicotômico e suscitem possibilidades ampliadas de efetivação do acolhimento.

A amplitude com que as dicotomias foram empregadas indica que pertencem a um estilo de pensamento generalizado nas sociedades, de modo que não parece exagerado associá-las aos discursos modernos, tal como entendidos por Latour (1989). Podemos dizer que, para esse autor, o modo de pensar moderno trabalha com uma ruptura entre passado e futuro, e entre partidários das condições vigentes em um e outro desses tempos. No caso dos discursos que deram origem aos CEUs e que continuam orientando boa parte dos servidores atuantes nesses equipamentos, trata-se de realizar uma leitura "purificada" - nos termos de Latour - da realidade política e social, baseada num antagonismo entre partidários e adversários do acolhimento.

Para alcançar essa forma esquemática de classificação, os discursos passam a reforçar divergências e minimizar pontos em comum com aqueles que consideram antagônicos, deixando de reconhecer parcelas de razão em certas preocupações com a segurança e relevando problemas 
trazidos com a ampliação de liberdades. As dicotomias passam a delinear separações entre grupos de servidores com diferentes visões da política e da administração pública, e os valores defendidos por eles também são vistos como opostos e incompatíveis: no CEU Butantã, o acolhimento opõe-se à garantia da segurança e da organização, e, em sua biblioteca, polarizam-se as preocupações com "usuários" e "livros". O dispositivo dicotômico prossegue sendo aplicado a outros materiais, transbordando a classificação de grupos e valores e passando a organizar também os contextos supostamente empregados por uns e outros: no campo da arquitetura, "espaços abertos" tornam-se os únicos associáveis ao acolhimento, enquanto "espaços fechados" associam-se exclusivamente à segurança e ao controle; analogamente, debates políticos defendem a "entrega" de poder e criticam a hierarquia e a centralização; polarizações semelhantes organizam a defesa de uma educação "libertadora" contra uma educação "opressora". Com isso, por exemplo, espaços abertos passam a relacionar-se apenas a efeitos desejáveis, e fechamentos de espaço tornam-se inteiramente indesejáveis. Assim é que se desfazem as dúvidas sobre linhas de ação a adotar e define-se o objetivo de maximizar extensividades.

Para alcançar este fim, escolhem-se muitas vezes meios que também podem ser relacionados ao dispositivo dicotômico, já que não há previsão de gradações ou etapas entre uma situação dada e outra almejada: procura-se implantar as extensividades de modo repentino, com espaços, normas e diretrizes que trazem já de início um máximo de liberdade de ações e interações. Muitas vezes a distância entre a realidade dada e a desejada é considerável, como quando os discursos recorrem às noções de um futuro ideal, "inédito" ou "utópico". ${ }^{171}$ Esta linha de ação parece ser inevitável quando adota-se uma concepção de história na qual a segunda e única alternativa consistiria no reforço de um passado de séculos de dominação. ${ }^{172}$

\footnotetext{
${ }^{171}$ Nas palavras da ex-secretária de Educação da gestão Marta Suplicy, Maria Aparecida Perez: "Talvez o acesso ao ballet, aos concertos musicais, às exposições de obras de arte possa significar a descoberta de uma ponte entre o presente e o futuro. A ponte como sinônimo da transformação, porque o sujeito insatisfeito com o presente quer transformar o futuro, e esta transformação exige realizar hoje o inédito viável de Freire" (PEREZ, 2010, p. 402). Outro exemplo significativo está na defesa da "utopia" como uma "ferramenta de trabalho" primordial, conforme a fala de uma educadora da DRE Butantã que presenciei durante uma palestra de formação que reuniu todos os gestores dos CEUs, organizada pela FIA (Fundação Instituto de Administração) em parceria com a Prefeitura do Município, em 21/11/2013.

${ }^{172}$ Esta visão de história aparece na principal publicação já realizada sobre os CEUs, o livro Educação, CEU e Cidade (DORIA, 2007). A primeira metade da obra tece uma narrativa histórica da educação em São Paulo, contrapondo um passado composto por séculos de dominação e um futuro de superação trazido com a construção dos CEUs. O relato traça equivalências, por exemplo, entre jesuítas, Marquês de Pombal e defesas mais recentes da escola privada (ibid., p. 95), considerando-os como reacionários e opondo-os a tendências progressistas que se desenvolvem e chegam ao presente. Nesse cenário, os CEUs aparecem como um ponto de ruptura em relação ao
} 
Parte das dificuldades encontradas na promoção do acolhimento no CEU Butantã parecem se relacionar à presença desse dispositivo dicotômico. Entre o reforço de um passado e a afirmação de um futuro, surgem questões no presente para as quais faltam respostas, dentre elas as que se referem ao processo gradativo de construção da condição desejada. Assim, encontramos defesas da maximização repentina das extensividades, mas não há um passo a passo de como fazer com que ela se torne compatível com o acolhimento. ${ }^{173}$ Dificuldades aparecem não apenas nos meios, mas também nos fins, já que, como vimos ao longo da pesquisa, a implantação exclusiva de extensividades não traz apenas efeitos desejáveis. Nos termos de Latour, podemos dizer que há discursos que procuram "purificar" as extensividades, não enxergando suas vinculações com impurezas ou "híbridos". Em nossos termos, isso significa: as extensividades são vistas apenas como garantidoras de liberdade de ação e interação, sem que se perceba sua vinculação com incertezas, desacelerações e outras ambiguidades, contradições e complexidades caracterizadoras do cotidiano de um centro educacional.

$\mathrm{Na}$ verdade, podemos supor que, por serem ignorados ou negados pelos discursos purificados, os híbridos ou impurezas encontram terreno para proliferar: "quanto mais nos proibimos de pensar os híbridos, mais seu cruzamento se torna possível" (LATOUR, op. cit., p. 16-17). Isso pode ser ilustrado com o exemplo concreto e trivial da afirmação: "queremos estar presentes não pela força, mas pela educação" (DORIA, 2007, p. 10). O silêncio sobre as parcelas de "força" (ou de hierarquia, de separações, de interações não voluntárias etc.), que afinal são inevitáveis a qualquer realidade social, tende a autorizar empregos diversos da "força", dentro de uma grande - já que indefinida - amplitude de variação. Nesse sentido, não há contradição entre discurso e prática, já que um produz a outra.

Desse modo, a multiplicação de separações que passou a ocorrer no cotidiano do CEU Butantã pode ser vista como consequência das defesas radicais da extensividade. Talvez isto ajude a entender por que a pedagogia da libertação, referência central no campo da educação, convive com as práticas que reprova, apresentando dificuldades em mitigá-las, e por que se defende tanto a abertura espacial das escolas, ao mesmo tempo que se permite a multiplicação de

passado, num momento em que "finalmente a educação de qualidade passa a ser acessível também àqueles segmentos sociais historicamente excluídos ao longo dos 450 anos da cidade" (id., p. 107).

${ }^{173}$ A noção de processo aparece apenas nas alegações de falta de tempo para o "enraizamento" do projeto dos CEUs, como forma de justificar o não atingimento dos objetivos almejados (DORIA, 2007 p. 7, 224; SOUZA, 2010, p. 9495). Mas é justamente este não atingimento que indica a dificuldade de pensar em termos de processo. Além disso, as próprias condições futuras tendem a não serem abordadas como passíveis de transformação, como se, ao serem alcançadas, devessem permanecer indefinidamente. 
portões, grades e outros controles de acesso. Parece haver uma relação de complementaridade entre esses pares de fenômenos. A amplitude destas constatações sugere que o dispositivo dicotômico mencionado seja comum a muitos campos e problemas de nossas sociedades, e não apenas aos discursos dos implementadores dos primeiros CEUs.

$\mathrm{Na}$ medida em que os aspectos tidos como indesejáveis são problematizados mais abertamente, tornam-se mais domesticáveis. A pesquisa seguiu nesta direção ao falar em contextos e suas combinações, gradações, significados, interdependências de efeitos desejáveis e indesejáveis, modos de associação com outros problemas e assim por diante. Por ser menos eloquente e mais complexa, a tarefa possui uma menor capacidade de propagação e difusão: ela nos obriga a "reduzir a marcha, curvar e regular a proliferação dos monstros através da representação oficial de sua existência" (LATOUR, op. cit., p. 17). Mas é a forma de evitarmos os problemas trazidos pela separação entre discurso purificado e realidade híbrida.

No entanto, essa diminuição de "marcha" não indica um abrandamento na perseguição de valores, que no caso dos CEUs relaciona-se ao acolhimento. ${ }^{174}$ Isso é demonstrado pelo que observamos no CEU Vila Rubi, que foi administrado de modo mais independente em relação aos discursos dicotômicos. Seus gestores estiveram mais dispostos a mobilizar intensividades e separações para promover o acolhimento e para combater os problemas trazidos pela extensividade. A já mencionada expressão "trabalho de formiguinha", que ouvi mais de uma vez entre os gestores do CEU Vila Rubi, alude à ideia de que o acolhimento se efetiva com a persistência de um trabalho cotidiano focado nas dificuldades do presente. Tal ideia, portanto, faz contraponto com a defesa de objetivos idealizados e distantes no tempo.

Nesse sentido, as necessidades de cada momento pareceram motivar reavaliações da relação entre dinâmicas interacionais e combinações de contexto. Conforme as ocorrências indesejadas do início da história do CEU Vila Rubi foram diminuindo, exigências de carteirinhas e outros controles de acesso passaram a ser empregados com menos frequência, ainda que não deixassem, ao final, de estar presentes em proporções minoritárias. Conforme as pessoas mudaram sua forma de utilizar o centro educacional, as extensividades foram sendo ampliadas, e

\footnotetext{
${ }^{174}$ Para ilustrar o ponto resgatamos as palavras de Clark ao propor uma mudança de tom nos discursos tradicionais da esquerda política: "é um erro supor que a moderação em política - se entendemos por isso uma política que se caracteriza por pequenos passos, por uma sabedoria desiludida, por propostas concretas, pelo desdém para com as promessas grandiosas, por uma consciência da dificuldade presente mesmo no 'avanço' mais mínimo - não seja revolucionária[...]. Uma política que, passo a passo, derrota após derrota, concentrasse seus esforços na tentativa de impedir que o tigre saia da jaula seria a mais moderada e revolucionária que jamais houve" (CLARK, 2012, p. 53).
} 
isso indica que o predomínio da liberdade de agir e interagir não é uma condição que precede a construção efetiva de diálogo e mútuo entendimento. Se após alguns anos houve uma ampliação da extensividade, não é porque ela foi vista como parceira exclusiva do acolhimento, de modo que tampouco parecia ser tratada como algo que não pudesse ser mudado e ajustado, eventualmente sofrendo reduções aqui e ali. A única meta estabilizada e de longo prazo era a de beneficiar os usuários e estabelecer relações de reciprocidade com eles, não estando diretamente condicionada à implantação exclusiva e definitiva de extensividades. Assim, os contextos puderam ser combinados conforme necessário para acumular parcelas de sucesso conquistadas a cada momento, e os esforços de promoção do acolhimento foram mais bem-sucedidos.

Convém reforçar novamente que a crítica aqui realizada aos discursos dos implementadores dos primeiros CEUs não tem a intenção de apontar para uma avaliação geral desses discursos, mas apenas indicar uma mudança de tom que poderia trazer incrementos significativos na promoção do acolhimento. Ficam assim esboçadas certas diretrizes que podem inspirar a administração e o desenho de políticas públicas, edifícios e mesmo de pedagogias. 


\section{REFERÊNCIAS BIBLIOGRÁFICAS}

\section{Fontes}

BARDI, Lina Bo; ELITO, Edison. Teatro Oficina. Lisboa: Instituto Lina Bo e P. M. Bardi/Blau, $1999, \mathrm{~s} / \mathrm{p}$.

CALlEGARI, Cesar. O direito à aprendizagem. Folha de S. Paulo. Caderno Opinião. São Paulo, 17 ago. 2013. Disponível em: <www1.folha.uol.com.br/opiniao/2013/08/1327867-cesarcallegari-o-direito-a-aprendizagem.shtml>. Acesso em: 10 out. 2014.

CENTRO CULTURAL SÃO PAULO. O ser público recriando os espaços do CCSP. São Paulo, 2013. Vídeo. Disponível em: <http://vimeo.com/41997318>. Acesso em: 11 fev. 2014.

CORBIOLI, Nanci. Nova proposta para o CEU revê conceito e desenho original. In: ProjetoDesign, n. 342, ago. 2008.

DO VAL, Ana P.; PEREIRA, Alexandre B. Relatório técnico mapeamento: Santo Amaro em rede-Culturas de Convivência. São Paulo: SESC/SP, 2010. (Relatório de pesquisa).

DORIA, Og Roberto. Educação, CEU e cidade: breve história da educação pública brasileira nos 450 anos da cidade de São Paulo. São Paulo: Secretaria Municipal de Educação da Cidade de São Paulo, 2007.

DUARTE, Hélio de Queiroz. Escolas classe escola parque: Uma experiência educacional. São Paulo: FAU-USP, 2009 (1973). 
FERRAZ, Marcelo Carvalho (coord.). Vilanova Artigas: arquitetos brasileiros - Brazilian architects. São Paulo: Instituto Lina Bo e P. M. Bardi/Fundação Vilanova Artigas, 1997.

FRATESCHI, Celso. Teatros, arquitetura e cidadania. Folha de S. Paulo, São Paulo, 22 maio 2003. Caderno Ilustrada, p. 2. Disponível em: <http://acervo.folha.com.br/fsp/2003/05/22/21>. Acesso em: 13 ago. 2014.

FREIRE, Paulo. Pedagogia do oprimido. 50. ed. rev. atual. Rio de Janeiro: Paz e Terra, 2011 (1968).

GADOTTI, Moacir. Educação com qualidade social: Projeto, implantação e desafios dos Centros Educacionais Unificados (CEUs). São Paulo, 2004. Disponível em: <www.paulofreire.org/Institucional/MoacirGadottiArtigos>. Acesso em: 15 jun. 2010.

GROSBAUM, Marta Wolak; CARVALHO, Lídia Izecson de. Os Centros Educacionais Unificados: um estudo de caso em São Miguel Paulista. São Paulo, 2008. Disponível em: $<$ www.ftas.org.br/ftas/site.php?mdl=download \&op=arquivo\& file=L2hvbW UvZnRhcy9wdWJsaWNfaHRtbC9mdGFzL3VwbG9hZC9hbmV4by9taWNyb3NvZnRfd29yZF9 fY2V1c19fb2sucGRm>. Acesso em: 02 out. 2010.

MARCÍLIO, Maria Luiza. História da escola em São Paulo e no Brasil. São Paulo: Imprensa Oficial do Estado de São Paulo/Instituto Fernand Braudel, 2005.

OLIVA, Luiza. Encontros com educadores: 50 entrevistas publicadas pela revista Direcional Educador. São Paulo: Exclusiva Publicações, 2010. 
ORENSTEIN, Helena; ANDRADE, Eduardo. São Paulo, cidade (a ser) aberta. Folha de S. Paulo, São Paulo, 10 fev. 2014. Disponível em:

$<$ www1.folha.uol.com.br/opiniao/2014/02/1409189-ivan-maglio-riscos-na-proposta-do-planodiretor.shtml>. Acesso em: 10 fev. 2014.

PINOTTI, José Aristodemo. Educação no Município de São Paulo: uma proposta para discussão. São Paulo, 2005a. In: Diário Oficial da Cidade de São Paulo, 24 fev. 2005, ano 50, n. 36.

Disponível em:

$<$ http://portalsme.prefeitura.sp.gov.br/Projetos/BibliPed/Anonimo/publicasmearq.aspx?MenuID= 28\&MenuIDAberto=24>. Acesso em: 27 nov. 2010.

. Relatório dos primeiros seis meses de gestão. São Paulo, 2005b. Disponível em: $<\mathrm{http}$ //portalsme.prefeitura.sp.gov.br/Projetos/BibliPed/Anonimo/publicasmearq.aspx?MenuID= 28\&MenuIDAberto=24>. Acesso em: 18 nov. 2010.

RIBEIRO, Darcy. O livro dos CIEPs. Rio de Janeiro: Bloch, 1986.

SANTOS, Valmir. Arquiteto ataca alteração em teatros de São Paulo. Folha de S. Paulo, São Paulo, 15 maio 2003. Caderno Ilustrada, p. 7. Disponível em:

$<$ http://acervo.folha.com.br/fsp/2003/05/15/21>. Acesso em: 13 ago. 2014.

SÃO PAULO (Cidade). Decreto n. 45.559, de 30 de novembro de 2004, aprova o Regimento Padrão dos Centros Educacionais Unificados. Diário Oficial do Município de São Paulo, São Paulo, ano 49, n. 224, p. 1, 2004.

. Portaria 4.672, de 05 de dezembro de 2006. Aprova o Regimento Padrão dos CEUs. 2006. 
. Decreto n. 54.823, de 7 de fevereiro de 2014, dispõe sobre a gestão compartilhada dos Centros Educacionais Unificados - CEUs entre as secretarias municipais de Educação, de Cultura e de Esportes, Lazer e Recreação. São Paulo, 2014. Disponível em:

$<$ www.leismunicipais.com.br/a/sp/s/sao-paulo/decreto/2014/5482/54823/decreto-n-54823-2014dispoe-sobre-a-gestao-compartilhada-dos-centros-educacionais-unificados-ceus-entre-assecretarias-municipais-de-educacao-de-cultura-e-de-esportes-lazer-e-recreacao.html >. Acesso em: 10 out. 2014.

SECRETARIA EXECUTIVA DE COMUNICAÇÃO (cidade de São Paulo). CEUs terão gestão compartilhada por Cultura, Educação e Esportes. São Paulo, 07 fev. 2014. Disponível em: <www.capital.sp.gov.br/portal/noticia/767\#ad-image-5>. Acesso em: 10 out. 2014.

SERAPIÃO, Fernando. Centro Cultural São Paulo: espaço e vida = Space and life. São Paulo: Monolito, 2012.

SOUZA, Ricardo de. A educação social em espaços de experimentação pedagógica: as potencialidades dos CEUs. Dissertação (Mestrado em Educação) - Faculdade de Educação, Universidade de São Paulo, São Paulo, 2010.

SPOSATI, Aldaíza. Mapa da exclusão/inclusão social da cidade de São Paulo. PUCSP/INPES/Pólis, 1996.

SUPLICY, Marta. Minha vida de prefeita: o que São Paulo me ensinou. Rio de Janeiro: Agir, 2008.

\section{Referências}

ANELLI, Renato Luiz Sobral. Centros Educacionais Unificados: arquitetura e educação em São 
Paulo. In: Vitruvius, 2004. Disponível em:

<www.vitruvius.com.br/revistas/read/arquitextos/05.055/517>. Acesso em: 23 maio 2013.

ARENDT. Hannah. A condição humana. Rio de Janeiro: Forense Universitária, 1987.

BASTOS, Maria Alice Junqueira. A escola-parque: ou o sonho de uma educação completa (em edifícios modernos). In: Arquitetura e Urbanismo, ed. 178, 2009. Disponível em: $<$ www.revistaau.com.br/arquitetura-urbanismo/178/a-escola-parque-ou-o-sonho-de-umaeducacao-completa-em-122877-1.asp>. Acesso em: 10 set. 2014

BENEVOLO, Leonardo. História da arquitetura moderna. São Paulo: Perspectiva, 1989.

BENJAMIN, Walter. Paris, capital do século XIX. In: FORTUNA, C. (org.). Cidade, cultura e globalização: ensaios de sociologia. Oeiras: Celta, 1997.

BERMAN, Marshall. Tudo que é sólido desmancha no ar: a aventura da modernidade. São Paulo: Companhia das Letras, 1986.

CALDEIRA, Teresa P. do R. Cidade de muros: crime, segregação e cidadania em São Paulo. São Paulo: ed. 34/ Edusp, 2000.

CLARK, T. J. Por uma esquerda sem futuro. São Paulo: ed. 34, 2012.

DALE, Karen; BURELL, Gibson. "All Together, Altogether Better": the Ideal of "Community" in the Spatial Reorganization of the Workplace. In: MARREWIJK, Alfons van; YANOW, Dvora (eds.). Organizational Spaces. Rematerializing the Workday World. Cheltenham, UK/Northampton, USA: Edward Elgar Publishing Limited, 2010. 
DELEUZE, Gilles; GUATTARI, Felix. Mil platôs: capitalismo e esquizofrenia. v. 2. São Paulo: ed. 34,1995 (1980).

FASANO, Edson. Centro Educacional Unificado, contraposição à "pedagogia de lata". Dissertação (Mestrado em Educação) - Faculdade de Educação e Letras, Universidade Metodista de São Paulo, São Bernardo do Campo, 2006.

FELTRAN, Gabriel. Transformações sociais e políticas nas periferias de São Paulo. In: KOWARICK, Lúcio; MARQUES, Eduardo (orgs.). São Paulo: novos percursos e atores sociedade, cultura e política. São Paulo: ed. 34/CEM, 2011.

FOUCAULT, Michel. Vigiar e punir: nascimento da prisão. Tradução de Raquel Ramalhete. Petrópolis: Vozes, 1987 (1975).

GEERTZ, Clifford. "From the Native's Point of View": On the Nature of Anthropological Understanding. Local Knowledge. New York: Basic Books, 1983.

GREENWOOD, Davydd J.; LEVIN, Morten. Introduction to Action-Research: social research for social change. 2nd ed. Thousand Oaks/London/New Delhi: Sage, 2007.

GUERREIRO, Isadora. CEUs: potencialidades e contradições. Monografia (Graduação em Arquitetura) - Faculdade de Arquitetura e Urbanismo, Universidade de São Paulo, São Paulo, 2006.

HERZFELD, Michael. Intimidade cultural: poética social do estado-nação. Coimbra: Edições $70,2008$. 
HIRSCHMAN, Albert O. Exit, voice and loyalty: responses to decline in firms, organizations and states. Cambridge: Harvard University Press, 1970.

GRAMSCI, Antonio. Maquiavel, a política e o Estado moderno. 4. ed. Rio de Janeiro: Civilização Brasileira, 1980.

JACOBS, Jane. The Death and Life of Great American Cities. New York: Vintage Books, 1961.

LATOUR, Bruno. Jamais fomos modernos: ensaio de antropologia simétrica. Rio de Janeiro: ed. 34, 1994.

. Paris: Invisible City. 2006. Disponível em: <www.brunolatour.fr/sites/default/files/downloads/viii_paris-city-gb.pdf $>$. Acesso em: 22 jan. 2013.

LEITE, Rogério Proença. Contra-usos da cidade: lugares e espaço público na experiência urbana contemporânea. Campinas: ed. da Unicamp/Aracaju: ed. UFS, 2004.

LEMOS, Charlene Kathlen de. Bibliotecas dos Centros Educacionais Unificados (CEUs): a construção de uma cultura comum. Dissertação (Mestrado em Ciência da Informação) - Escola de Comunicações e Artes, Universidade de São Paulo, São Paulo, 2012.

PACHECO, Reinaldo Tadeu Boscolo. O espetáculo da educação: os Centros Educacionais Unificados no Município de São Paulo como espaços públicos de lazer. Tese (Doutorado) Faculdade de Educação, Universidade de São Paulo, 2009. 
PEDROSIAN, E. Álvarez. Crear, aprender y compartir: apuntes epistemológicos sobre la integralidad. In: AROCENA, R.; PEDROSIAN, E. Álvarez et al. Integralidad: tensiones y perspectivas. Cuadernos de Extensión, n. 1, Montevideo: SCEAM-UdelaR, 2011. p. 61-83.

PEREIRA, Alexandre Barbosa. "A maior zoeira": experiências juvenis na periferia de São Paulo. Tese (Doutorado em Antropologia Social) - Faculdade de Filosofia, Letras e Ciências Humanas, Universidade de São Paulo, São Paulo, 2010.

PEREZ, Maria Aparecida. Inclusão social através da educação: um estudo do programa Centro Educacional Unificado em São Paulo. Tese (Doutorado) - Universität Siegen, Siegen, 2010.

RANDOLPHO, Angela R.; BURGOS, Marcelo Baumann (org.). A escola e a favela. Rio de Janeiro: ed. PUC-Rio/Pallas, 2009.

SAX, William. Agency. In: KREINATH, Jens; SNOEK, Jan; STAUSBERG, Michael. Theorizing Rituals: Issues, Topics, Approaches, Concepts. Leiden/Boston: Brill, 2006. p. 473481.

SENNETT, Richard. O declínio do homem público: as tiranias da intimidade. São Paulo: Companhia das Letras, 1988 (1974).

TILLY, Charles. Coerção, capital e estados europeus (1990-1992). São Paulo: Edusp, 1996.

WARREN, Mark E. Democracy and Association. Princeton/Oxford: Princeton University Press, 2001. 
WEBER, Max. A ciência como vocação. In: Ciência e Política: duas vocações. São Paulo: Cultrix, 1970. 